\title{
A Feasibility Analysis of the Implementation of Passive Treatment Systems for Remediating Acid Mine Drainage in the Lick Run Watershed
}

William Joseph Leonetti

Follow this and additional works at: https://researchrepository.wvu.edu/etd

\section{Recommended Citation}

Leonetti, William Joseph, "A Feasibility Analysis of the Implementation of Passive Treatment Systems for Remediating Acid Mine Drainage in the Lick Run Watershed" (2014). Graduate Theses, Dissertations, and Problem Reports. 6061.

https://researchrepository.wvu.edu/etd/6061

This Thesis is protected by copyright and/or related rights. It has been brought to you by the The Research Repository @ WVU with permission from the rights-holder(s). You are free to use this Thesis in any way that is permitted by the copyright and related rights legislation that applies to your use. For other uses you must obtain permission from the rights-holder(s) directly, unless additional rights are indicated by a Creative Commons license in the record and/ or on the work itself. This Thesis has been accepted for inclusion in WVU Graduate Theses, Dissertations, and Problem Reports collection by an authorized administrator of The Research Repository @ WVU. For more information, please contact researchrepository@mail.wvu.edu. 


\title{
A Feasibility Analysis of the Implementation of Passive Treatment Systems for Remediating Acid Mine Drainage in the Lick Run Watershed
}

\author{
William Joseph Leonetti \\ Thesis Submitted to the \\ Benjamin M. Statler College of Engineering and Mineral Resources \\ at West Virginia University \\ in partial fulfillment of the requirements \\ for the degree of \\ Masters of Science \\ In \\ Civil and Environmental Engineering
}
Leslie Hopkinson, Ph.D., Chair
John Quaranta, P.E., Ph.D.
Jason Fillhart, M.S., M.Ed.

Department of Civil and Environmental Engineering

Morgantown, West Virginia

2014

Keywords: Acid Mine Drainage (AMD), Watershed Based Plan (WBP), Best Management Practices (BMP), Nonpoint Sources of Pollution (NPS), Passive Treatment Systems, Constructed Wetlands 


\title{
Abstract
}

\section{A Feasibility Analysis of the Implementation of Passive Treatment Systems for Remediating Acid Mine Drainage in the Lick Run Watershed}

\author{
William Joseph Leonetti
}

Historical mining operations, mostly coal mining, has left the State of West Virginia with many abandoned mine lands that often produce nonpoint sources of Acid Mine Drainage (AMD) pollution. This work studied a small tributary to the Cheat River, Lick Run, which has been heavily impaired by AMD through legacy coal mining. Field and laboratory water quality testing verified that Lick Run does not meet Water Quality Standards (WQS). The purpose of this research was to evaluate current stream conditions of Lick Run and to provide means of remediation through passive treatment systems to reduce metal and acidity loads.

Lick Run is located in Preston County, West Virginia. Within the watershed, a total of six mine portals and three in-stream sites were monitored, along with two locations on the Cheat River. Water quality testing was performed quarterly from July 2013 to May 2014. Field tests measured $\mathrm{pH}$, conductivity, total dissolved solids (TDS), dissolved oxygen (DO), and temperature. Grab samples were analyzed for $\mathrm{pH}$, alkalinity, acidity, sulfate $\left(\mathrm{SO}_{4}\right)$, conductivity, iron (Fe), aluminum $(\mathrm{Al})$, calcium (Ca), magnesium $(\mathrm{Mg})$, and manganese $(\mathrm{Mn})$. Benthic macro-invertebrate communities were also assessed at the in-stream sampling locations (October 2013 and May 2014); West Virginia Stream Condition Index (WVSCI) metrics were calculated.

Watershed characteristics were evaluated to help assess pollutant transfer fates. Characteristics included coal seam boundaries, elevations, soils, land use, impervious surfaces, imagery, natural wetland areas, sampling locations, problem area description locations, and abandoned mine lands. AMD Treat was utilized to help determine appropriate module dimensions and to generate cost estimates for each system.

Results of the project suggest that treatment of the watershed to $80 \%$ reduction of metal and acidity loads is feasible, but capital costs are high (greater than $\$ 2,000,000$ ). Once the proposed systems are built, however, little maintenance would be required, thus operating costs would be low during the expected lifespan of 20 years. Macro-invertebrate assessments revealed that stream conditions of Lick Run were poor to marginal. Levels of $\mathrm{pH}$ were below WQS with values that were nearly 4 for most sites. While this indicates considerable acid loads, these are reasonable levels for management and treatment purposes. Iron and aluminum concentrations proved to be the most detrimental to the watershed. 


\section{Acknowledgements}

I would like to thank the many people who have made this research possible; their support and positive influence will not be forgotten. Among these people, I would like to highlight a few.

Dr. Leslie Hopkinson, for her guidance and support through graduate studies. I am sincerely grateful for your encouragement, inspiration, and kind advice. Dr. John Quaranta, for the many wise words and opportunities through undergrad to graduate life. I am genuinely appreciative of your support and the opportunities that you have empowered me with. I owe Drs. Hopkinson and Quaranta for an excellent and rewarding graduate experience; I will not dismiss the invaluable knowledge and sound advice that they have provided me with.

I would also like to thank the good people of the West Virginia Water Research Institute (WVWRI). They provided me with the tools, equipment, and instruction to properly complete stream surveys. Specifically, I would like to thank Jason Fillhart and Ben Mack. Their support and camaraderie made sample collections enjoyable and educational. I value the time given for the experience gained by working for the WRI, and feel blessed for the opportunity to have traversed WV's scenic landscape while studying its interesting, historical impairments. I also owe Chance Chapman a thanks for helping with sample collections.

Finally, I would like to dedicate this thesis to my family for their unconditional love and endless support. This accomplishment would not have been possible if it weren't for the values and lessons passed onto me during my life. I owe my parents for instilling in me the importance of education, devotion to commitment, and desire for more. 


\section{Grant Information}

This thesis details portions of data that were collected for the Watershed Based Plan for Lick Run of the Cheat River (HUC-12 \#050200040702). Funding for the Lick Run project was provided through a grant from the West Virginia Department of Environmental Protection (WVDEP), which effectively takes on West Virginia Clean water Act (CWA) responsibilities. The projects purpose is to be considered for CWA Section 319 funding. The plan was developed by the West Virginia Water Research Institute (WVWRI), the WVDEP Division of Water and Waste Management (WVDEP-DWWM), and the Friends of the Cheat (FOC) watershed association. 


\section{Table of Contents}

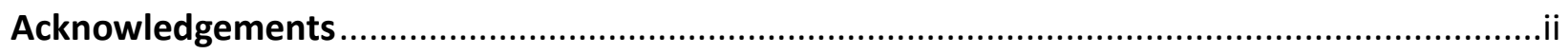

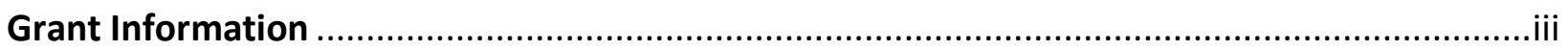

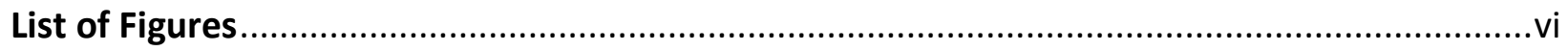

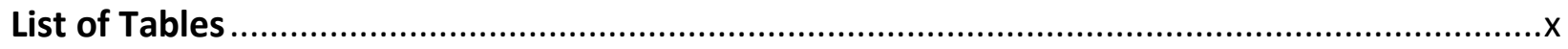

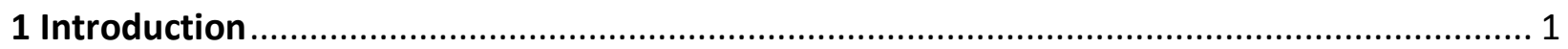

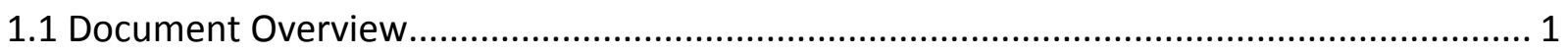

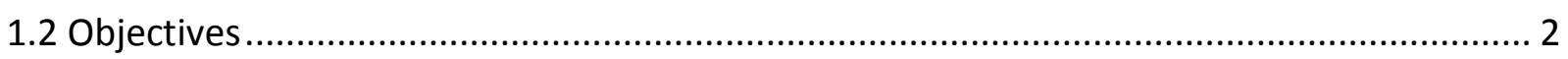

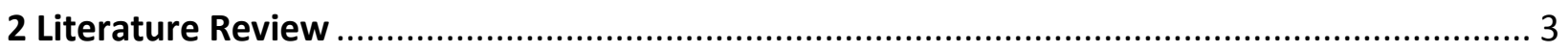

2.1 Watershed Based Plan (WBP) .................................................................................. 3

2.2 Total Maximum Daily Load (TMDL) ............................................................................... 4

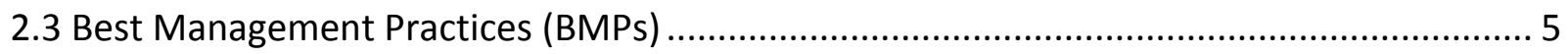

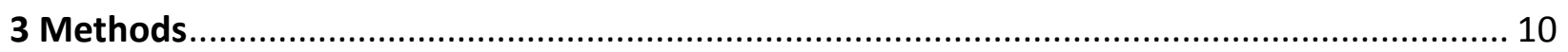

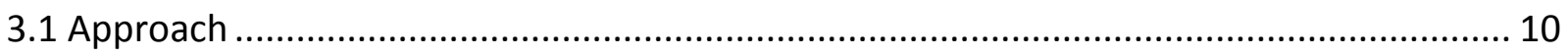

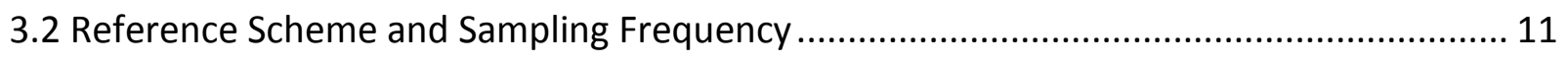

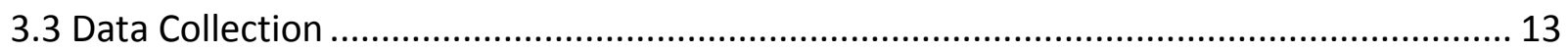

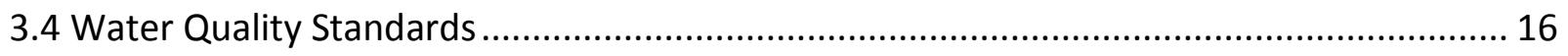

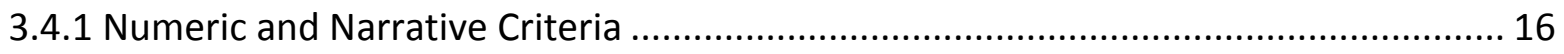

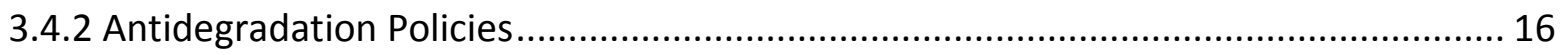

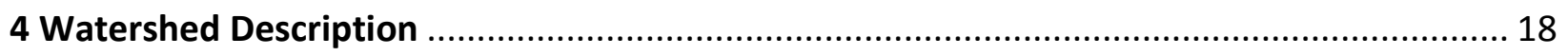

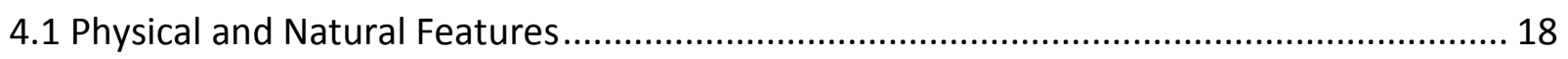

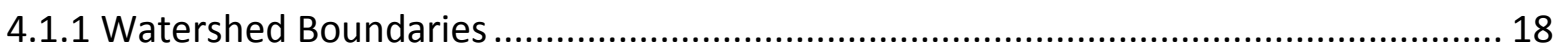

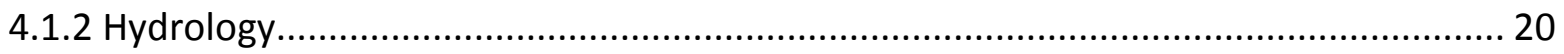

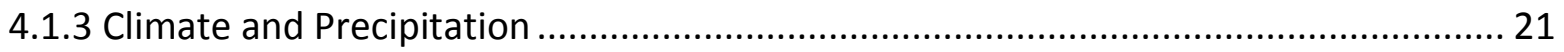

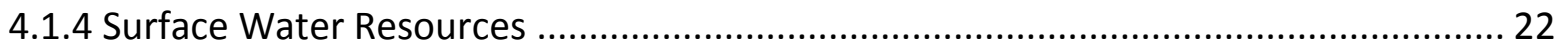

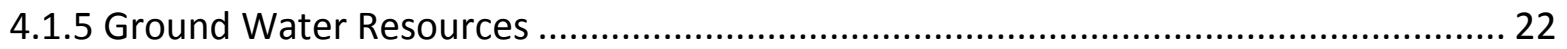

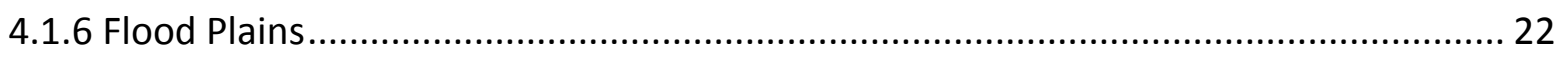

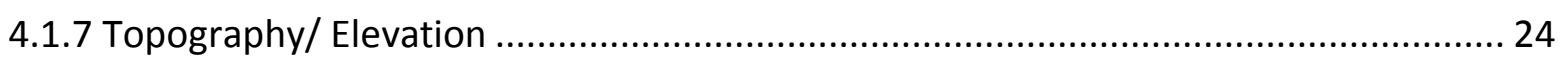

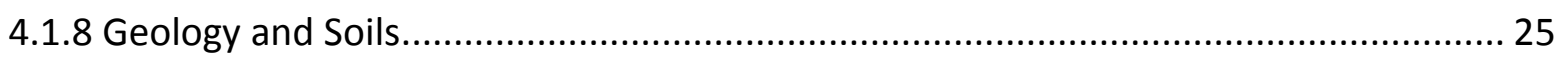

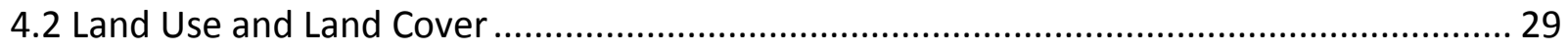

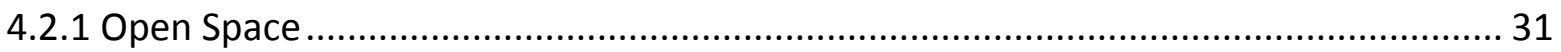




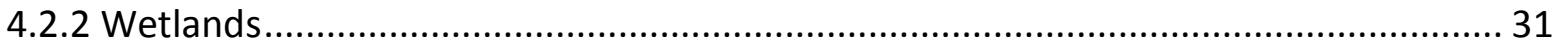

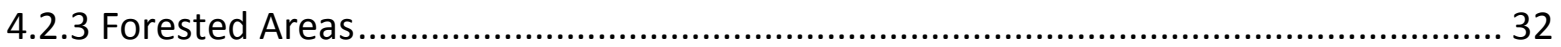

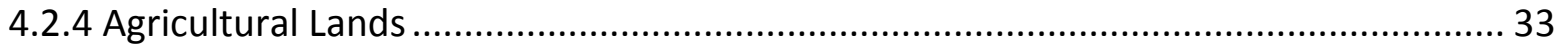

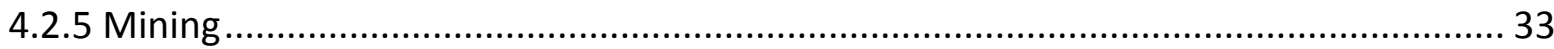

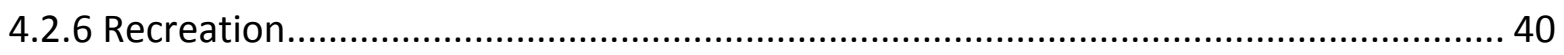

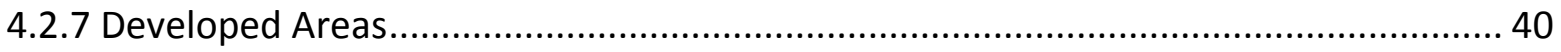

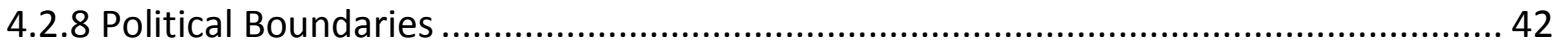

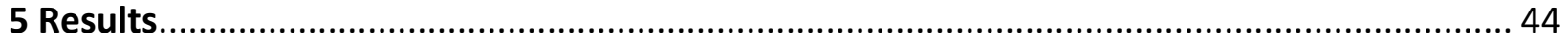

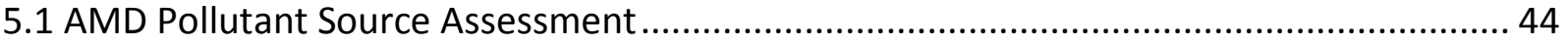

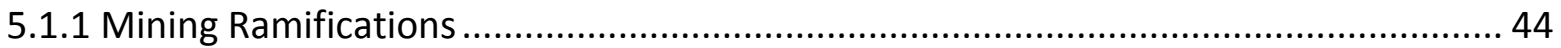

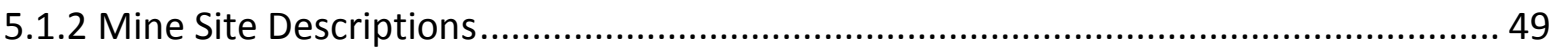

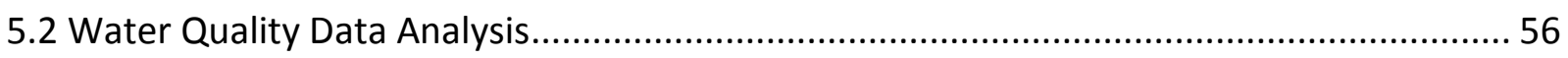

5.2.1 Metal Concentrations and pH Compared to Water Quality Standards ..................... 56

5.2.2 Effect of Lick Run Discharge on the Cheat River ................................................... 61

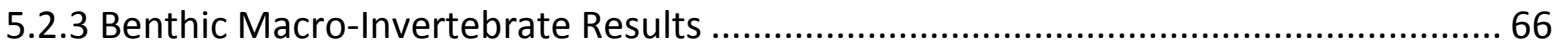

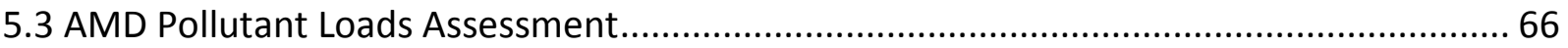

5.3.1 Existing Conditions and Pollutant Load Estimates ................................................ 66

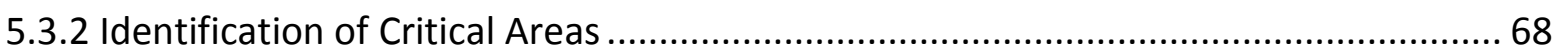

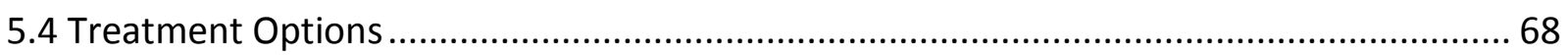

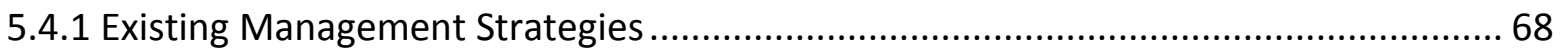

5.4.2 Additional Strategies Needed to Achieve Water Quality Standards ...........................69

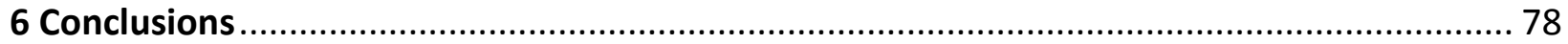

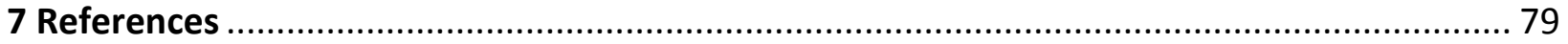

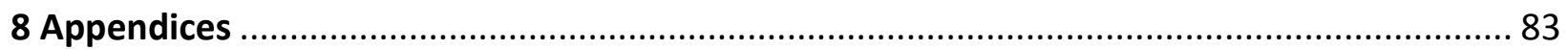

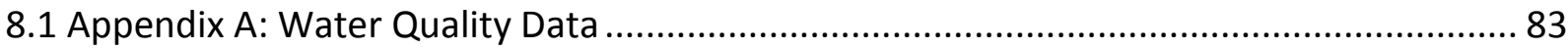

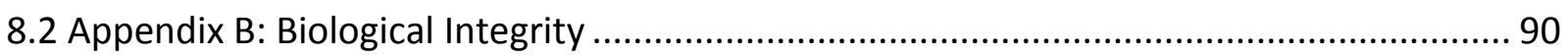

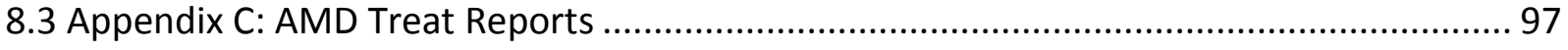




\section{List of Figures}

Figure 1: Flowchart depicting the general approach taken for development of this thesis....... 10

Figure 2: WVWRI referencing scheme, in-stream sampling points, and mine-site sampling points.

Figure 3: High definition image of the Lick Run watershed and surrounding area provided by Google Maps. Scale bar $=2000$ feet.

Figure 4: Lick Run watershed and its encompassing HUC 12 watershed. This figure also highlights Lick Runs stream path. 19

Figure 5: Low definition imagery of the Lick Run watershed and stream path. 20

Figure 6: FEMA Flood Hazard Risk in Lick Run. The dark blue lines show Lick Runs stream path, areas shaded light blue is the estimated 100 year floodplain. 23

Figure 7: Digital Elevation Model of the Lick Run watershed. Higher elevations are shown in dark green and lower elevations are shown in lighter green/ white. Elevation values are given in feet above Mean Sea Level (msl)....

Figure 8: General soil types in the Lick Run watershed, this figure goes with Table 1.............. 26

Figure 9: Detailed soil types in the Lick Run watershed, this figure goes with Table 2. ............. 28

Figure 10: Land use/ land cover map. This figure goes with Table 3. .................................. 30

Figure 11: Wetlands in Lick Run, according to the National Wetlands Inventory (NWI). ........... 32

Figure 12: Full extent of the Upper Freeport Coal Seam................................................... 35

Figure 13: The Upper Freeport Coal Seam within Lick Runs watershed, and Lick Runs encompassing HUC 12 watershed.

Figure 14: Underground Mining within the Lick Run watershed. Watershed boundaries are not available, though, reference points are shown.

Figure 15: Topographic map of Lick Runs discharge into the Cheat River; the Bottom Fork is shown near the center of the map. Surface and strip mined areas are shown in brown and grainy purple 
Figure 16: Topographic map of Lick Runs headwaters, the Top Fork is shown near the center of the map. Surface and strip mined areas are shown in brown and grainy purple. 39

Figure 17: Street map by Google Maps. Scale bar $=2000$ feet. 41

Figure 18: Impervious Surfaces Map. 42

Figure 19: Land owned by Friends of the Cheat within the Lick Run watershed. Location information: District 01, Map 20, PID 35. Full scale bar $=400 \mathrm{~m}$.

Figure 20: Map of Problem Area Descriptions (PADs) within the Lick Run watershed. This figure corresponds with Table 4. 45

Figure 21: Abandoned mine land territories and mining permit boundaries in the Lick Run watershed.

Figure 22: Lick Run \#2 limestone channels and stream path convergence before discharging into Lick Runs mainstem. 50

Figure 23: Lick Run \#4; P1s open portal. 51

Figure 24: Lick Run \#4; P2s open portal. 51

Figure 25: Lick Run \#4, P3s rock outcrop/ open portal. 52

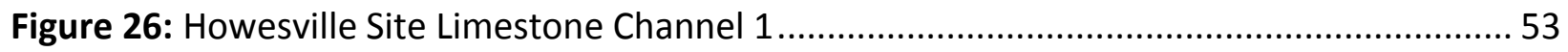

Figure 27: Howesville Site Limestone Channel 2 ............................................................ 53

Figure 28: Howesville Sites two AMD source convergence. 54

Figure 29: Howesville Greaser first convergence, looking downstream; three AMD sources merge here and then flow into the valley to another convergence (Figure 30). 55

Figure 30: Howesville Greaser second convergence, looking upstream; the first convergence is located up the hill and the other channel comes from the fourth AMD source.

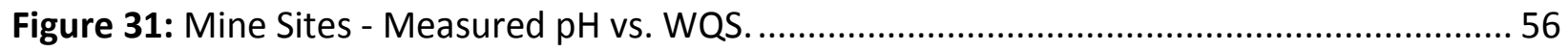

Figure 32: In-Stream Sites - Measured pH vs. WQS......................................................... 57

Figure 33: Mine Sites - Measured Al Concentration vs. WQS. ............................................. 58

Figure 34: In-Stream Sites - Measured Al Concentrations vs. WQS. .................................... 58 
Figure 35: Mine Sites - Measured Fe Concentrations vs. WQS.

Figure 36: In-Stream Sites - Measured Fe Concentrations vs. WQS..................................... 59

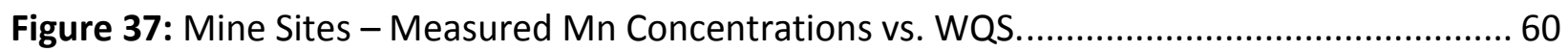

Figure 38: In-Stream Sites - Measured Mn Concentrations vs. WQS. .................................... 60

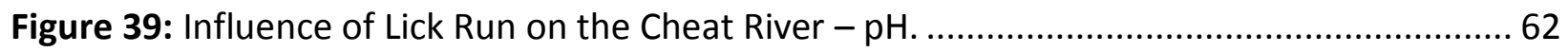

Figure 40: Influence of Lick Run on the Cheat River - Al............................................... 62

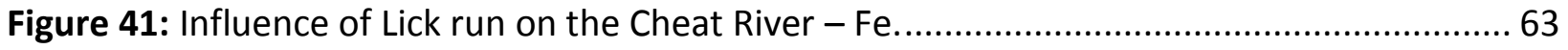

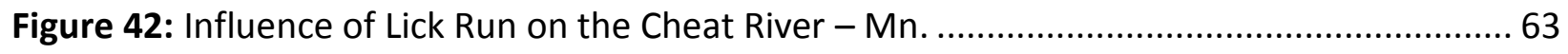

Figure 43: Lick Runs mouth and Discharge into the Cheat River. ....................................... 64

Figure 44: Cheat River bank, looking downstream. A small portion of Lick Runs discharge can be seen in the bottom left portion of the frame. ....................................................................... 65

Figure 45: Cheat River Bank, looking upstream. Shot taken from below Lick Runs discharge; it can be seen that there is no apparent armoring or visible AMD effects on the Cheat River, prior to Lick Runs discharge. 65

Figure 46: Trib 1s discharge into Lick Run, looking upstream. Trib 1 is located on the left side of the shot. 73

Figure 47: Lick Run mainstem at Trib 1s conflux, looking downstream................................. 73

Figure 48: Conceptual sketch of the Howesville Greaser remediation system. ...................... 74

Figure 49: Conceptual sketch of the Lick Run \#4 remediation system. .................................. 75

Figure 50: Conceptual sketch of the Middle Start remediation system................................. 76

Figure 51: Conceptual sketch of the Trib 1 DS remediation system..................................... 77

Figure 52: AMD Treat report for the Howesville Greaser system.......................................... 98

Figure 53: AMD Treat report for the Lick Run \#4 system................................................ 99

Figure 54: AMD Treat report for the Middle Start system............................................... 100 


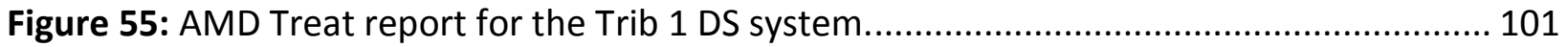




\section{List of Tables}

Table 1: General soil types in the Lick Run watershed, this table goes with Figure 8.

Table 2: Detailed soil types in the Lick Run watershed, this table goes with Figure 9.

Table 3: Land use/ land cover categories and percentages. This table goes with Figure $10 \ldots . . . .31$

Table 4: List of Problem Area Descriptions (PADs) within the Lick Run watershed. All funded problem areas have been completed (reclaimed). This table corresponds with Figure 20....... 46

Table 5: Average mine-site water quality data $(n=4)$. Plus signs $\left({ }^{+}\right)$denotes three sample values. Values in parenthesis represent ranges in measured flowrates.

Table 6: Average in-stream water quality data $(n=4)$. Plus signs $\left({ }^{+}\right)$denotes three sample values, asterisks $(*)$ denote single sample values. Values in parenthesis represent ranges in measured flowrates.

Table 7: Detailed analysis of Lick Runs impacted stream segments. 49

Table 8: Benthic Macro-Invertebrate Sample Results. 66

Table 9: Annual mine-site pollutant loadings $(n=4)$. Plus signs $\left({ }^{+}\right)$denote three sample values.

Table 10: Annual in-stream pollutant loadings $(n=4)$. Plus signs $\left({ }^{+}\right)$denote three sample values, asterisks $(*)$ denote single sample values.

Table 11: Mine site sampling points. 83

Table 12: In-stream sampling points. 84

Table 13: Raw mine site sampling results. 85

Table 14: Raw in-stream sampling results. 87

Table 15: Condensed field and lab results. 89

Table 16: Benthic Macro-invertebrate sampling points. 90

Table 17: WVSCI assessment results - Trib 1 DS - sample set 1. 91 


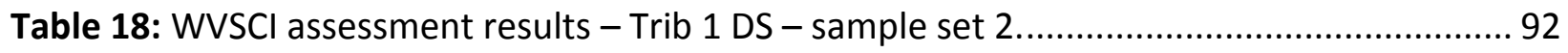

Table 19: WVSCl assessment results - Bottom Fork Middle - sample set 1....................... 93

Table 20: WVSCl assessment results - Bottom Fork Middle - sample set 2. ......................... 94

Table 21: WVSCl assessment results - Discharge Mouth - sample set 1.............................. 95

Table 22: WVSCl assessment results - Discharge Mouth - sample set 2............................ 96 


\section{Introduction}

\subsection{Document Overview}

Much of West Virginia's (WV's) landscape has been negatively affected by Acid Mine Drainage (AMD). Legacy coal mining has left the state riddled with abandoned mine lands that produce nonpoint sources of pollution. Today, mining impacts are regulated by the Clean Water Act (CWA) and its amendments of 1972. Government organizations such as the United States Environmental Protection Agency (EPA), and the Office of Surface Mining Reclamation and Enforcement (OSMRE), have been given the authority and responsibility to monitor and reclaim these abandoned mine lands throughout the country. Specifically, abandoned mine lands refer to mines that were abandoned before 1972. Most of these mines have been left un-reclaimed with many high priority safety issues, as well as AMD contaminated waters discharging through various cracks, crevices, and abandoned mine portals. The most significant source of funding for the reclamation of legacy coal mine-water quality issues are provided through the CWA Section 319.

In order for watershed groups to acquire CWA Section 319 funding, they must complete a Watershed Based Plan (WBP). A WBP is a document that identifies major environmental impacts on a watershed. They are often used for nonpoint sources of pollution, which makes them excellent for displaying effects from AMD.

This document details a portion of the Watershed Based Plan for Lick Run of the Cheat River (HUC-12 \#050200040702). More specifically, this thesis explores the feasibility of implementing passive treatment remediation strategies on the Lick Run watershed, through a scaled down WBP approach. The WBP for Lick Run used Total Maximum Daily Load (TMDL) reports, the Abandoned Mine Land Information System (AMLIS), and the National Pollutant Discharge Elimination System (NPDES) in order to conduct the most comprehensive analysis to produce the most accurate results possible.

This thesis will provide a brief literature review on WBPs and TMDL reports, with a broader evaluation of Best Management Practices (BMPs). BMPs are essentially measures taken to collect, control, and treat NPS pollution, in this case, specifically for AMD. Also, the methods taken in order to generate original data to assess Lick Run's health will be detailed. Test results will be displayed in the forms of processed data sheets and detailed graphs. Finally, a general, but thorough treatment strategy, including four systems, will be presented and discussed.

Lick Run is located in Preston County, WV, south of Kingwood. The active watershed association, known as Friends of the Cheat, provided the impetus for the baseline water sampling that was performed for use in the WBP. The 2011 Cheat River TMDL provides historic water quality data and TMDLs for the Cheat River and all of its tributaries, including Lick Run (Tetra Tech 2011). It 
lists Lick Run as impaired by $\mathrm{pH}$, iron, aluminum, and manganese, leading to diminished benthic macro-invertebrate populations. All five of these parameters will be investigated in this report.

\subsection{Objectives}

The objective of this thesis is to provide a detailed feasibility analysis on the remediation of AMD in Lick Run, through passive treatment systems. It will detail the general treatment strategy that was developed for the WBP, which used WV recognized passive treatment modules, linked together to form individual systems. The accumulation, of historic watershed data, existing and future projected watershed characteristics, and research efforts were performed in order to create the most comprehensive and feasible treatment strategy that technology and the scopes of the WBP project would allow. All data and analyses from the WBP that is pertinent to AMD contamination will be presented and discussed in this document.

The ultimate goal of the treatment strategy is to provide means of remediation to achieve $80 \%$ reduction of metal and acid loads. The West Virginia Water Research Institute (WVWRI) uses $80 \%$ reduction as their standard treatment target because treating past this mark becomes exponentially more difficult and requires significantly more resources. This will bring Lick Runs hydrology drastically closer to being within water quality standards (WQS). The objective of the CWA is to restore all US water to be within WQS, thus allowing the propagation of fish and other aquatic creatures, as well as contact recreation. Once these levels are reached, a target body of water, in this case Lick Run, can be taken off of the CWA 303(d) list of impaired waters.

The feasibility analysis for this thesis includes specific objectives that are detailed below:

- Identify water quality standards (WQS) for Lick Run

- Provide means of remediation to $80 \%$ reduction of metal and acid loads (treatment strategy)

- Analyze land requirements to determine feasibility

- Provide a cost analysis for the proposed treatment strategy

- Develop module/ system lifespans 


\section{Literature Review}

\subsection{Watershed Based Plan (WBP)}

Watershed Based Plans (WBPs), are documents produced by organizations that are seeking approval for the Clean Water Act (CWA), section 319 funding. CWA section 319 funding provides the most significant amount of subsidy for projects related to mine land reclamation, and provides the best chance of cleaning up West Virginia's state-wide hydrological issues that have developed through legacy coal mining. WBPs outline sources of negative impact to a watersheds hydrology by investigating selected high-impact point and nonpoint sources that have influence; with an emphasis on nonpoint source (NPS) pollution, they provide stream health assessments throughout the watershed and determine areas of most importance for means of remediation.

Section 101(a) of the CWA defines its primary objective as the restoration and ability to maintain chemical, physical, and biological integrity of the Nation's waters. The act establishes national goals to achieve fishable and swimmable waters wherever attainable, and to eliminate the discharge of pollutants into U.S. Waters (USEPA 2012a; WEF 2011). The CWA established a program to define water quality standards (WQS) and to regulate permit discharges into U.S. waters in order to help achieve and assess progress of their goals (USEPA 2012b; WEF 2011).

Throughout the world, quality of naturally occurring streams and water bodies have degraded due to human development. Surface and groundwater quality continues to degrade due to impacts seen from agricultural, urban, forest, and mining NPS pollution. The CWA of 1972, and its amendments of 1987, brought NPS pollution to international attention (Nag 2010a).

Section 303(d) of the CWA requires that states identify impaired bodies of water that do not meet water quality standards. All bodies of water that are on the 303(d) list of impaired waters are required to have a total maximum daily loads (TMDL) developed in order to address each pollutant causing impairment (USEPA 2012b; Chang 2011). These TMDLs should provide restoration scenarios with an ultimate goal of having the subjective body of water removed from the 303(d) list by attaining water quality standards (Nag 2010a).

Watershed based plans are essentially models for depicting and predicting current and future hydrological quality of a watershed and its components based on the effects from point and nonpoint sources. With limited resources available (time, labor, and funding), it is imperative that control and implementation programs focus on critically contributing areas and adequately consider the impacts of alternative management, land use, and conservation practices (Nag 2010a). These alternatives should help to identify water quality impacts, prioritize human activities related to socioeconomic development, and suggest practical remediation strategies under different levels of environmental stress in the context of sustainability (Chang 2011). Modeling strategies based on experimental data are often the only feasible means of providing sensible contributions to economical management decisions (Nag 2010a). NPS pollutant fate and 
transport process modeling, at a watershed scale, is essential for addressing an areas surface and ground water impairments (Nag 2010a).

The integration of geographic information systems (GIS) with distributed parameter hydrologic models has taken on an increasingly important role in the management of water quality and water resources. Modern GIS software has the ability to capture, manage, manipulate, analyze, and output spatially referenced data such as points, lines, and polygons, or a unit space. Some examples of relevant features to watershed modeling that GIS software can project include streams, rivers, watershed boundaries, watershed outlets, point sources, elevation contours, water quality and stream flow measurement locations, soil type polygons, and land/ use land cover polygons (Nag 2010a).

Authority to implement the CWA rests with the U.S. EPA, though, the EPA reserves the ability to delegate this authority to a state, if it demonstrates that it has a program at least as stringent as its own regulations (WEF 2011). In the case of West Virginia, the WV Department of Environmental Protection (DEP), has been delegated the authority to implement the CWA. The WV DEP defines a watershed based plan as follows: WBPs focus on addressing issues identified by the 303(d) list and TMDLs, with the ultimate goal of restoring the waterbody so it can meet water quality standards (WVDEP 2014b).

This watershed based plan utilizes generated data as well as historical data to produce cost effective, sustainable treatment scenarios. ArcGIS Maps was used to model Lick Run to develop detailed figures of its characteristics. AMD Treat was used to estimate abatement costs of Acid Mine Drainage (AMD), and to aid in module design considerations for its treatment systems.

\subsection{Total Maximum Daily Load (TMDL)}

As defined by section 303(d) of the Clean Water Act, a TMDL is a calculation of the maximum amount of a pollution that a water body can receive and still safely meet water quality standards (USEPA 2012c). TMDLs are published in reports that incorporate analysis of all hydrology within a single large-scale watershed; they are administered by the authoritative figure of the particular region, that which implements the CWA. This thesis uses TMDLs for Lick Run that is provided by the 2011 Cheat River TMDL (Tetra Tech 2011).

TMDLs are essentially pollutant budgets; they determine the total load of a pollutant that a body of water can receive while maintaining WQS, they also allocate allowable portions of the pollutant load to each significant source. Sources include point, nonpoint, and uncontrollable (natural) background sources of pollution (WEF 2011). Every TMDL accounts for all sources of a constituent including discharges from wastewater treatment facilities; runoff from urban stormwater; nonpoint sources from forested, agricultural fields, and contaminated soils and sediments; on-site septic systems; and deposits from the air. TMDL constituents may include 
legacy pollutants such as polychlorinated biphenyl (BCP) and dichlorodiphenyl trichloroethane (DDT), regular pollutants such as metals, pathogens, biochemical oxygen demand (BOD)/ chemical oxygen demand (COD), and physical water quality parameters such as $\mathrm{pH}$ and temperature (Chang 2011).

TMDL reports not only account for past and current development activities but also consider projected industrial growth which could increase pollutant levels in the future. They also identify best management practices (BMPs) that will assure that WQS are attained and maintained after implementation. TMDL procedures were established by regulations published by the U.S. EPA in 1992 (Chang 2011). The one, major obstruction to successful TMDL applications is that the CWA does not provide any legal authority for mandating nonpoint sources to reduce pollutant loads (WEF 2011).

The TMDL computation is defined as (Davis 2010):

$$
T M D L=\sum W L A+\sum L A+M O S
$$

WLA = waste load allocations (point sources)

$\mathrm{LA}=$ load allocations (nonpoint sources)

MOS = margin of safety

WLAs pertain to portions of the TMDL that are assigned to existing and anticipated point sources, whereas LAs pertain to portions of the TMDL that are assigned to existing and anticipated nonpoint sources (Davis 2010). According to Davis 2010, the margin of safety is to account for uncertainties about the relationship between loadings and water quality.

\subsection{Best Management Practices (BMPs)}

Best management practices in regards to AMD remediation are measures taken to minimize nonpoint source pollution on a system/ water body of interest. BMPs can support passive or active treatment strategies using structural or nonstructural treatment modules. Implementation of BMPs on a hydrologic system incur an ultimate goal of the systems effluent to meet WQS. For the sake of limited resources and funding, the Lick Run restoration project focuses on passive treatment strategies that use nonstructural controls.

A best management practice is a module, or a combination of modules that form a system used for preventing or reducing nonpoint source pollution, and/ or for managing flow volume in an economic and effective manner (Nag 2010b). Passive treatment systems are those that do not require continuous dosing of an ingredient in order to be effective, thus require little 
maintenance over long periods of time. They are generally self-preserving and sustainable when compared to active treatment systems, but sometimes can incur more expensive or impractical startup costs (Johnson and Hallberg 2005). Structural controls are essentially engineering solutions that incorporate physical mechanisms or structures in order to trap and treat polluted waters; nonstructural controls, on the other hand, focus on protecting natural systems by incorporating existing landscape into site plans. BMP selection should be based on considering factors such as the primary pollutant(s) of concern, site conditions including land use, topography, slope, water table elevation, geology, climate, and economical restraints (Nag 2010b).

NPS pollution can be acknowledged and managed from two angles including prevention and protection, and treatment and control (Nag 2010b). In the context of AMD pollution, prevention is not always feasible because most damage has already occurred and the results are products of natural response (Cravotta 2010; Johnson and Hallberg 2005). Treatment and control of AMD producing sources is often the best course of action for AMD remediation and mine land reclamation (Johnson and Hallberg 2005). The overlying objective of treating AMD is to reduce pollutant loads and concentrations to levels that meet water quality standards through chemical, physical, and/ or biological processes (Nag 2010b). A controlling factor in reducing metal loads from $A M D$ is $\mathrm{pH}$, which must be at or above 4 to allow for adequate oxidation (Johnson and Hallberg 2005).

Watershed models have generally limited capabilities in regards to modeling BMP effects in order to provide precise treatment projections. The U.S. EPA pressed upon the need for improved ability of models to evaluate the effectiveness of BMPs to manage many stressors, including suspended solids and sediments, in their 2002 Twenty Needs Report (Nag 2010b; USEPA 2002). Modern software has been improved, but progress in this area is still necessary. Today, the WVDEP encourage WBP creators to use AMD Treat to help model impaired streams of interest. According to the Office of Surface Mining Reclamation and Enforcement, AMD Treat is a computer application for estimating abatement costs for pollutional mine drainage (OSMRE 2014). In this report, Lick Run's proposed treatment systems have been analyzed using AMD Treat in order to help determine module dimensions and estimated costs.

The three prominent module strategies that are suggested for the abatement of Lick Run are alkalinity producing systems, detention basins/ ponds, and wetlands. Alkalinity producing systems introduce large amounts of alkaline material in order to raise $\mathrm{pH}$ and promote metal precipitation (Johnson and Hallberg 2005). Detention basins and ponds are cells that hold water for a certain duration before release; they are helpful for controlling floods and downstream erosion while promoting sedimentation with considerable storage area for collection. The other module of interest is wetlands, specifically free water surface - aerobic wetlands, which are effectively the centerpiece of the Lick Run remediation strategy. Natural wetlands are excellent natural filters. They essentially act as a sink for waste, being capable of assimilating large amounts of environmental contaminants, while providing ample space and opportunity for detaining sediment; by acting like a sponge, wetlands even help to mitigate flooding events (Nag 2010b; Cohen 2006; Sheoran 2006). 
The WVDEP provides an overview of passive systems for treating AMD, including aerobic and anaerobic wetlands, alkalinity producing systems, anoxic limestone drains, limestone ponds, and open limestone channels. Like most passive AMD treatment systems used today, these systems focus on using limestone to produce alkalinity in order to decrease acidity and ultimately raise $\mathrm{pH}$ to acceptable levels. A description of the six modules are presented below (Skousen et al. 2000):

1) Aerobic Wetlands: Generally used to collect water and provide residence time so that aeration can occur and metals can precipitate. Aerobic wetlands are practical for treating water that has net alkalinity (Cravotta 2006; Johnson and Hallberg 2005; Skousen et al. 2000). Aerobic systems are dominated by shallow and surface processes, thus constructed aerobic wetlands are generally kept to a depth of within $1 \mathrm{ft}$. (Lee et al. 2013).

2) Anaerobic Wetlands: Encourage water passage through rich, organic substrates in order to filter and effectively treat AMD. Anaerobic wetland substrates may contain limestone in order to further raise alkalinity and promote the precipitation of metals (Skousen et al. 2000). Some anaerobic wetlands incorporate deep ponds with depths greater than $1 \mathrm{ft}$. (Lee et al. 2013).

3) Alkalinity Producing Systems (APS): Buried cells that incorporate large amounts of limestone in order to produce alkalinity. The goal of all APS are to stimulate the precipitation of metals by reducing acidity. APS are highly variable, often times used in succession, and can incorporate a drain for increased control and management (Skousen et al. 2000). Water draining APS systems are frequently directed to a sedimentation pond or an aerobic wetland in order to collect and retain hydroxide precipitates (Johnson and Hallberg 2005). Results from testing performed in Gangneung, South Korea suggest retention times of 1 to 2 days to be appropriate and economical for APS systems (Lee et al. 2013).

4) Anoxic Limestone Drains (ALD): Buried cells or trenches of limestone of which anoxic water is passed through; as limestone dissolves in acid water, $\mathrm{pH}$ levels are effectively raised, indicating an increase in alkalinity (Lee et al. 2013; Skousen et al. 2000). ALDs have increased rates of limestone dissolution due to the increase in partial pressure of carbon dioxide in the drain. Though ALDs can be highly effective, they are not always suitable for flow with high concentration of metals, specifically ferric iron and aluminum. The accumulation of hydroxide precipitates decrease drain permeability and can eventually lead to failure by clogging; clogging has been documented to occur as early as 6 months after construction (Cravotta 2006; Johnson and Hallberg 2005). Drain maintenance and more frequent need for limestone replacement makes ALD systems more costly than other treatment systems (Cravotta 2006). Field tests in Gangneung, South Korea support that ALD systems are effective for increasing limestone dissolution, but require at least 15 hours of retention time (Lee et al. 2013). 
5) Limestone Pond: Ponds that have limestone introduced for passive treatment. These ponds are designed around retention time and limestone loading in order to raise $\mathrm{pH}$, increase alkalinity, and ultimately encourage the precipitation of metals. The advantage of this module is that armoring can be seen because the module is not buried; this way, it is easier to tell when maintenance is required, or if the limestone has been exhausted due to dissolution and acid neutralization (Skousen et al. 2000). Retention times of 1 to 2 days have been shown to be appropriate and economical for settling ponds (Lee et al. 2013).

6) Open Limestone Channel (OLC): Open channels or ditches lined with limestone that introduce alkalinity to acid water (Skousen et al. 2000). OLCs are the most practical way for transporting AMD, therefore are often used for conveyance. Optimal performance is attained on slopes exceeding $20 \%$ so that flow velocities keep precipitates in suspension, thus helping to prevent armoring of limestone surfaces (Skousen et al. 2000). According to Skousen et al. 2000, the armoring of limestone surfaces reduce its rate of dissolution to $20 \%$ the rate of when unarmored.

Wetland systems have been recognized for their ability to improve water quality by significantly reducing oxygen demanding substances including BOD and ammonia, nutrients such as nitrogen and phosphorous, suspended solids, and metals. Removal mechanisms that take place during wetland treatment include physical, chemical, and biological operations as well as plant uptake. Biological operations are achieved by algal and microbial activity. Physical operations are apparent through sedimentation as suspended solids settle during calm, shallow flow. Chemical operations incur by means of chemical precipitation, soil absorption, and nitrification/ denitrification. Plant uptake is accomplished by select macrophytes, most commonly incorporating emergent plant species that include cattails and bulrushes (Sheoran 2006; Cohen 2006; Johnson and Hallberg 2005; Corbitt 1999).

Constructed wetland treatment systems are relatively easy systems to operate and maintain when compared to conventional mechanical systems; they are energy efficient and require little amounts of maintenance over long periods of time. They strive to emulate the properties of natural wetlands within an environment that can be controlled and manipulated (Sheoran 2006; Cohen 2006; Corbitt 1999). A three year study in Gangneung, South Korea indicated retention times of 1 to 2 days to be appropriate and economical for constructed wetlands (Lee et al. 2013). Constructed wetlands have the ability to enhance the aesthetic value of an area and provide educational value as a nature study area (Corbitt 1999). Some constructed wetlands have been designed to serve as a public park as well, providing educational benefits to the general public. Individual wetlands enjoy a sense of uniqueness instilled by varying hydroperiods, soils, and plant communities among other factors (Corbitt 1999).

Hydrology has the most influence for determining plant composition based on what species can survive during a wetlands entire hydroperiod. A hydroperiod is the relationship of water depth and period of inundation over an annual cycle. Hydroperiod considerations are critical to the successful development of wetland treatment systems (Sheoran 2006; Corbitt 1999). Flow 
designs should emphasize low velocities with shallow depths in order to optimize removal mechanism by increasing surface contact time with substrates and vegetation, as well as providing favorable conditions for sedimentation (Cohen 2006).

Soil type is one of the most important physical components of a wetland system. Factors such as mineral composition, organic matter content, moisture regime, temperature regime, chemistry, and depth directly influence the types of plants and microorganisms that can succeed within the system. FWS wetlands require soils with very low to no permeability in order to restrict drainage. The installation of a clay or synthetic impermeable layer below coarse substrate, such as sand, provides excellent filtration while providing the ability to isolate and maintain the system's water controls (Corbitt 1999).

Characteristics of the plants that are favorable for wetland use include plant species that can survive designed hydroperiods, species that form dense stands or litter zones, and species that provide high nutrient and mineral sorption capability. Cattails and bulrushes are among the most researched plant species for wetland treatment systems; they are both capable of growing in shallow and relatively deep waters, achieving similar heights, and forming very dense stands with well-developed litter zones (Corbitt 1999). Wetland vegetation can also help to increase sedimentation rates by acting as sediment traps (Sheoran 2006).

The ultimate purpose of the wetlands designed for this thesis and its project scope is to provide suitable environment for the efficient removal of metals from AMD. The processes by which this occurs generally includes chemical oxidation or reduction which leads to metal precipitation, sorption by plants and soil, and simple filtration and sedimentation (Cohen 2006; Corbitt 1999). A closer look reveals that these removal mechanisms include cation exchange, photodegredation, phytoaccumulation, biodegradation, microbial activity, and plant uptake (Sheoran 2006).

Wetlands in general work best when supplemented with other treatment modules. Suspended grit and large solids present a chance to clog areas of a wetland, allowing the accumulation of pollutants to impact water quality within the treatment system. Preliminary treatment in order to remove apparent grit and large solids as well as the reduction of settleable solids and BOD should be administered to waters that will be treated by a wetland. Also, the greater the amount of pretreatment prior to entering a wetland, the lesser the land requirements that the wetland system will demand (Corbitt 1999). 


\section{Methods}

\subsection{Approach}

A general flowchart depicting the approach taken for the development of this thesis is provided below, in Figure 1. This flowchart shows the general steps taken in necessary order; the length of the boxes provide a general idea of the amount of time spent on each task. The begninning and end of each box shows an estimated start and end point for each task, in relevance to each other. This chart starts at the blue box and finished at the yellow box.

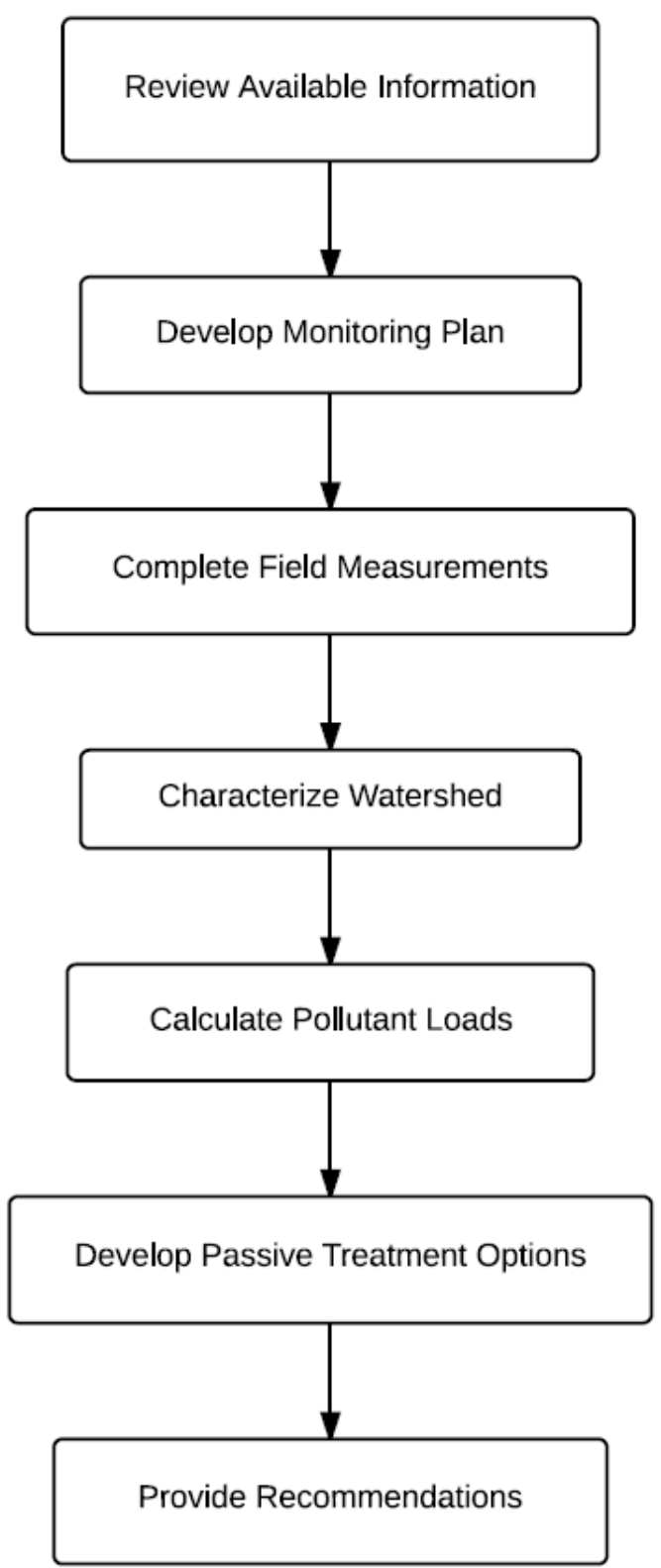

Figure 1: Flowchart depicting the general approach taken for development of this thesis. 


\subsection{Reference Scheme and Sampling Frequency}

The following, (Figure 2) depicts the Lick Run watershed, referencing schemes, and sampling locations developed by WVWRI (WVGISTC 2014). The only references that are not clearly labeled in this figure are the Bottom Fork and Top Fork. The Bottom Fork is located further downstream at Lick Run \#4s location, where the Middle Start Tributary flows into Lick Run's mainstem; the Top Fork is located closer to the headwaters of the watershed, where the Southern Start Tributary flows into the mainstem. Most of these locations were sampled four times, following the quarterly sample testing regime that was created by WVWRI.

The Discharge Mouth sample location is not accurate, these coordinates may have been taken from the field vehicle parking location. The Trib 1 sample points are depicted to have been taken at the same spot, this is due to the very close proximity of the three sample points, and because two of them were only taken once, during the final sample set. The Erroneous Heather Run sample was taken during the first sample set and was mistaken for the Top Fork North location. All of these sample points were recorded using a Garmin Rino 650 handheld GPS, apart from the Howesville Greaser site. The Howesville Greaser recorded location shows the site to be outside of the watershed; this is most likely due to the coordinates being taken at the field vehicle parking location and GPS inaccuracies. The AMLIS coordinates were used to depict this sites location instead. Lists of stream reference points, which points were sampled comprehensively, and their coordinate locations are provided in Appendix A. 


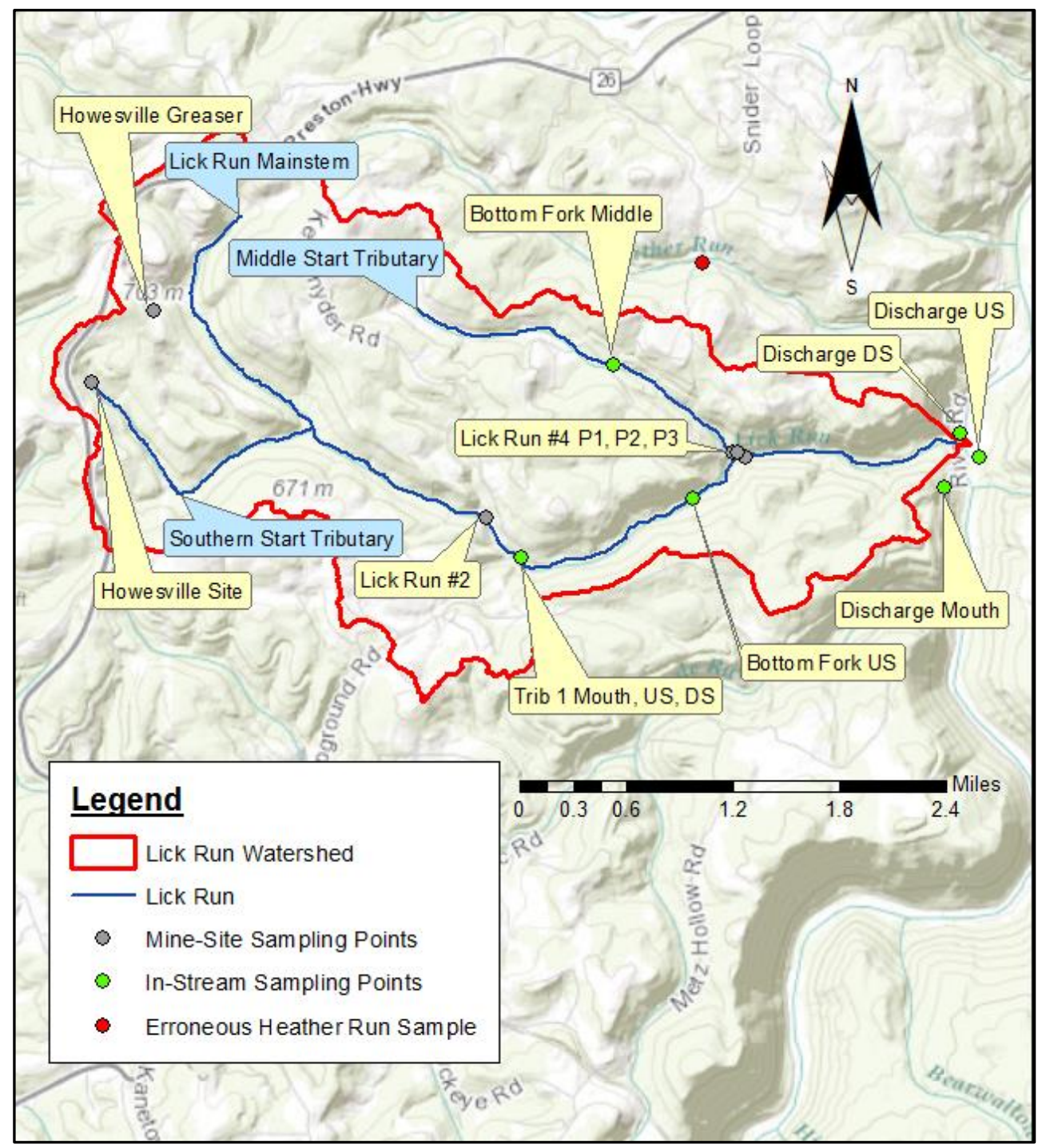

Figure 2: WVWRI referencing scheme, in-stream sampling points, and mine-site sampling points.

All samples were planned to be taken quarterly over a year for a total of four samples each. The Lick Run \#4 site includes three separate sampling points, two of which are bonafide open mine portals known as Portals 1 and 2. The other sampling point is at the mouth of the Middle Start tributary; this site was tested and referred to as Lick Run \#4 Portal 3 because contaminated water seeps out of at least one large rock outcrop along the mouth's stream bank, effectively adding AMD from an unfound portal/ source.

During the sampling period, some of the sites were removed and added based on accessibility, when they were found, and/ or when they were realized to be in an incorrect location. Because of this, the Lick Run \#4 P3, Bottom Fork Middle, Bottom Fork US, Trib 1 Mouth, and Trib 1 US sites have less than four samples each. The Lick Run \#4 P3 and Bottom Fork Middle sites have only three samples because these points were not found until the second sample set. Trib 1 Mouth and Trib 1 US only have one sample tested, during the final set, to be used as a reference to the Trib 1 DS samples. Trib 1 Mouth was originally planned to be sampled four times, but it was 
realized by the fourth set that the samples were pulled from DS of the Mouth. Bottom Fork US was removed from the sampling list due to inaccessibility. The erroneous Heather Run sample is not discussed nor are results presented in the body of this report, though, the full record of results are provided in Appendix $A$.

\subsection{Data Collection}

Three different types of data were collected during the sampling phase of this watershed based plan. Field data were taken using a YSI Multimeter and a flowmeter, grab samples were collected for more comprehensive lab testing, and benthic macro-invertebrate assessments were completed. Grab samples and flow and YSI measurements were taken quarterly over the yearlong sampling period; macro-invertebrate samples were taken twice (October and May), during this time. All three testing strategies were performed following recommended procedures that are detailed below.

\section{Field Tests}

A YSI 556 MPS Multimeter was used to measure $\mathrm{pH}$, temperature, conductivity, total dissolved solids (TDS), and dissolved oxygen (DO). The procedure for this tool is simply to fully submerge the YSI probe apparatus into a target body of water. The probe apparatus should have the protective cover applied and should be allowed to generate results over a period of time of about 5 minutes, or when all of the measurements have evened out and have ceased to fluctuate.

The other field generated data that was created were flow measurements. Of the two flowmeters that were used, a Marsh-McBirney, Inc. Flow-Mate model 2000 portable flowmeter and a SonTek FlowTracker Handheld ADV, both devices follow the same technique for calculating final values. The difference is that the SonTek FlowTracker computes the final discharge for the user, whereas the Flow-Mate 2000 acts more as a velocimeter by providing velocity measurements only, so that the final discharge value must be calculated by the user. The formula used for determining stream flow measurement is shown below; this formula was developed by the United States Geological Survey (USGS), and is supported by the U.S. Environmental Protection Agency (USEPA). Also, a brief step by step procedure of the process taken for streamflow determination for this report is provided. It is a variation of the USGS approach and also complies with the USEPA (USGS 2014b).

1) Total width of the stream was measured using a Kobalt, 300 foot long open reel fiberglass measuring tape.

2) Individual stream width increments were created.

3) Depth measurements were taken with the wading rod at the midpoint of each of the width increments.

4) Velocity measurements were produced by the flow meter at the midpoint of each of the width increments, at the center of the water column. 
5) Final flow measurements were calculated using the following formula.

$$
Q=\sum_{i}^{n}\left(W_{i} * D_{i} * V_{i}\right) * C F
$$

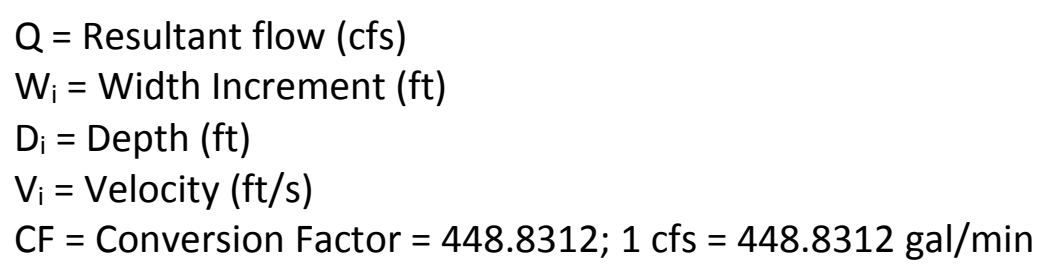

\section{Lab Tests}

Lab tests performed for this report were administered by the National Research Center's (NRCCE's) Analytical Laboratory. The samples that were tested were gathered by the WVWRI and were produced by slight variations of the Interagency Field Manual for the Collection of Water-Quality Data, which was developed by the USGS, in cooperation with the USEPA (USGS 2000a). Two grab samples were collected at every location for each sample set including a raw sample and a filtered, acidic sample for dissolved metal concentration determination.

All samples were collected closer to the edge of the streams, as opposed to the center as denoted by the interagency report. They were taken at a distance agreed by the WVWRI to be sufficiently far enough into the middle of the stream where adequate mixing had occurred. Lick Run's discharge included three sample locations that were within about 50 yards of each other (Lick Run Mouth, Lick Run US, and Lick Run DS). These locations were approved by the sampling team to have been located far enough away from each other to have sufficient readings respective to the locations interest; results obtained from these samples support this assumption.

A simple, small filtering apparatus, known as a Nalgene Filter Holder with Receiver, was used in order to remove all imperfections from water samples that would be used to test dissolved metal concentrations. The filtering apparatus incorporated two cells divided by a filter, of which Millipore Mixed Cellulose Ester filtering paper with $0.45 \mu \mathrm{m}$ openings was used. A small handheld break pump was attached to the bottom cell of the apparatus which provided the ability to generate pressure within the system in order to pull the sample water in the top cell through the filter paper, into the bottom cell. Once filtered, the water was stored in a bottle with a few drops of Nitric Acid administered in order to keep metals suspended in the water until testing was performed. The raw samples were taken as a control and backup to the filtered samples; all bottles used for transportation were made of \#2 high-density polyethylene (HDPE) and were provided by the NRCCE's lab. All water samples were kept on ice and covered to avoid exposure to direct sunlight until received by the lab. The NRCCE Analytical Laboratory analyzed the samples for $\mathrm{pH}$ (method 150.1), alkalinity (method SM2310A), acidity (method SM2310B), sulfate (method 375.4), conductivity (method SM2510B), and dissolved aluminum, calcium, iron, magnesium, and manganese, all of which used method number 200.7. 


\section{Benthic Macro-invertebrate Assessment}

The last factor for determining stream health was benthic macro-invertebrate assessments. These assessments were performed at selected locations throughout Lick Run's hydrology and utilizes the WV Stream Condition Index (WVSCI) calculation (Gerritsen et al. 2000). The collection of macro-invertebrate samples were performed based on the WV Department of Environmental Protection's (WVDEP's) macroinvertebrate assessment procedures that have been developed through minor adjustments to the US EPA Rapid Bioassessment Protocols (RBPs). For the sake of the scope of this report and its limited resources, a slightly altered collection and sorting process was followed, but WVSCI score calculations were closely adhered too. A listed description of the collection process is detailed below (WVDEP 2012; Gerritsen et al. 2000; Barbour et al. 1999).

1) Kick locations were determined by finding a representative riffle, run, and pool within the site location.

2) A kick was performed at each of these locations at each site. Three "kicks" would be performed unless a clear surplus of $100+$ creatures were found before all three kicks were administered.

3) A Lamotte two-pole screen-barrier net (kick-net) was set up downstream of the kicking locations. Large local rocks within the kick area were scrubbed upstream of the kick-net; selected, flat rocks, were placed as weights to keep the bottom of the net down to capture all material, including macro-invertebrates, that were carried downstream.

4) Kicks were initiated by gently kicking the rocks and sediment at the bottom of a stream in order to disturb macro-invertebrate populations living within the stream bed and effectively causing them to be carried downstream by the force of flow. The kicking area of interest was about $0.25 \mathrm{~m}^{2}$ in front of the net for each kick and the net collected most of the creatures that were exhumed.

5) After each kick, the resulting material within the net was briefly sorted and much of the unwanted debris was removed. Large organic matter was rinsed and removed from the sample and fine sediments were filtered out using a high value sieve (small openings).

6) Finally, the resultant debris from all three kicks were collected into a single large jar for each site and transported to the WVWRI laboratory for comprehensive sorting and analysis following WVSCI procedures.

For storage purposes, and transportation to the lab, all samples were kept on ice and doused with isopropyl in order to kill and preserve macro-invertebrates. Analysis of the samples were performed within two weeks of sample production and samples were stored in a refrigerator until taxonomic determinations were complete. The process by which the organisms were divided and compiled generally follows the WVSCl suggested procedures. The samples were manipulated by additional sifting and then broken down into smaller samples to be analyzed one at a time. Benthic macro-invertebrates were sorted and collected into ice trays by species and family by the use of tweezers and a small team of environmental scientists and myself. After sorting was complete, WVSCI scores were applied by the type of species and family, and the abundance of them. WVSCl score sheet results are provided in Appendix B of this report. 


\subsection{Water Quality Standards}

All streams within West Virginia are regulated by the WV Department of Environmental Protection (WVDEP). Regulations concerning WV water quality standards (WQS) are promulgated under Title 47 (Series 2) of the WVDEP Water Resources code, entitled "Requirements Governing Water Quality Standards."

According to the WV Legislative Rules for the DEP, the WQS Rule 47CSR2 requires, at a minimum, all waters of the State of West Virginia to be designated for the propagation and maintenance of fish and other aquatic life (Category B) and for water contact recreation (Category C). Category $B$ waters include warm water fishery streams, trout waters, and wetlands. Category $C$ includes swimming, fishing, water skiing, and certain types of pleasure boating such as sailing in very small craft and outboard motor boats (WVDEP 2014a).

\subsubsection{Numeric and Narrative Criteria}

Numeric criteria will be used to determine whether or not Lick Run is meeting WQS. Numeric criteria is preferred in the case of Lick Run because the main source of pollution (acid mine drainage) is known and it is likely that these pollutants could negatively affect human health. WQS for $\mathrm{pH}$, aluminum, iron, and manganese have been pulled from the 47CSR2 - Requirements Governing Water Quality Standards (WVDEP 2014a). These standards will address the impairments that are recognized by the 2011 Cheat River TMDL (Tetra Tech 2011).

In the case of Lick Run, WVWRI compares water quality to B4 aquatic life and human health standards. B4 aquatic life refers to wetlands, which are sparsely represented in the watershed now, but are the centerpiece of the remediation strategy. B1 and B2 aquatic life refers to warm water fishery streams and trout waters respectively. It is suspected that Lick Run could support substantial fish life, including trout, if water quality improved significantly. These standards are more stringent than those for B4 and human health, though, so WVWRI strives to meet B4 and human health standards first. For WQS, this report specifically refers to concentration levels of $0.75 \mathrm{mg} / \mathrm{l}$ of aluminum (Al), $1.5 \mathrm{mg} / \mathrm{l}$ of iron (Fe), and $1.0 \mathrm{mg} / \mathrm{l}$ of manganese (Mn).

\subsubsection{Antidegradation Policies}

According to the WVDEP, antidegredation refers to federal regulations designed to maintain and protect high quality waters and existing water quality in other waters from unnecessary pollution (WVDEP 2014c). The State of West Virginia's antidegredation policies can be found in Title 60, Series 5 of the WV Department of Environmental Protection Secretary's Office, entitled 
"Antidegredation Implementation Procedures". This rule divides state waters into three tiers; Tier 1 is the lowest quality of water whereas Tier 3 is the highest quality of water (WVDEP 2008). Lick Run is a Tier 1 watershed because it is listed on WV's 1998 EPA 303(d) list for pH and metals. Tier 1 protection states that "existing uses and the level of water quality necessary to protect the existing uses shall be maintained and protected (WVDEP 2008)". Tier 1 watersheds are waters of the state in which "water quality is not sufficient to support recreation and wildlife and the propagation and maintenance of fish and other aquatic life or where the water quality meets but does not exceed levels necessary to support recreation (WVDEP 2008)". 


\section{Watershed Description}

\subsection{Physical and Natural Features}

Lick Run is a direct drain into the Cheat River and is located south of Kingwood, WV and north of Tunnelton, WV. This nearly $5 \mathrm{mi}^{2}$ watershed is located entirely within Preston County. Figure 3, below, shows a high definition image of the Lick Run watershed and its surrounding area. A low definition image of Lick Run with its watershed, encompassing HUC 12 watershed, and hydrology, is provided in Figure 5.

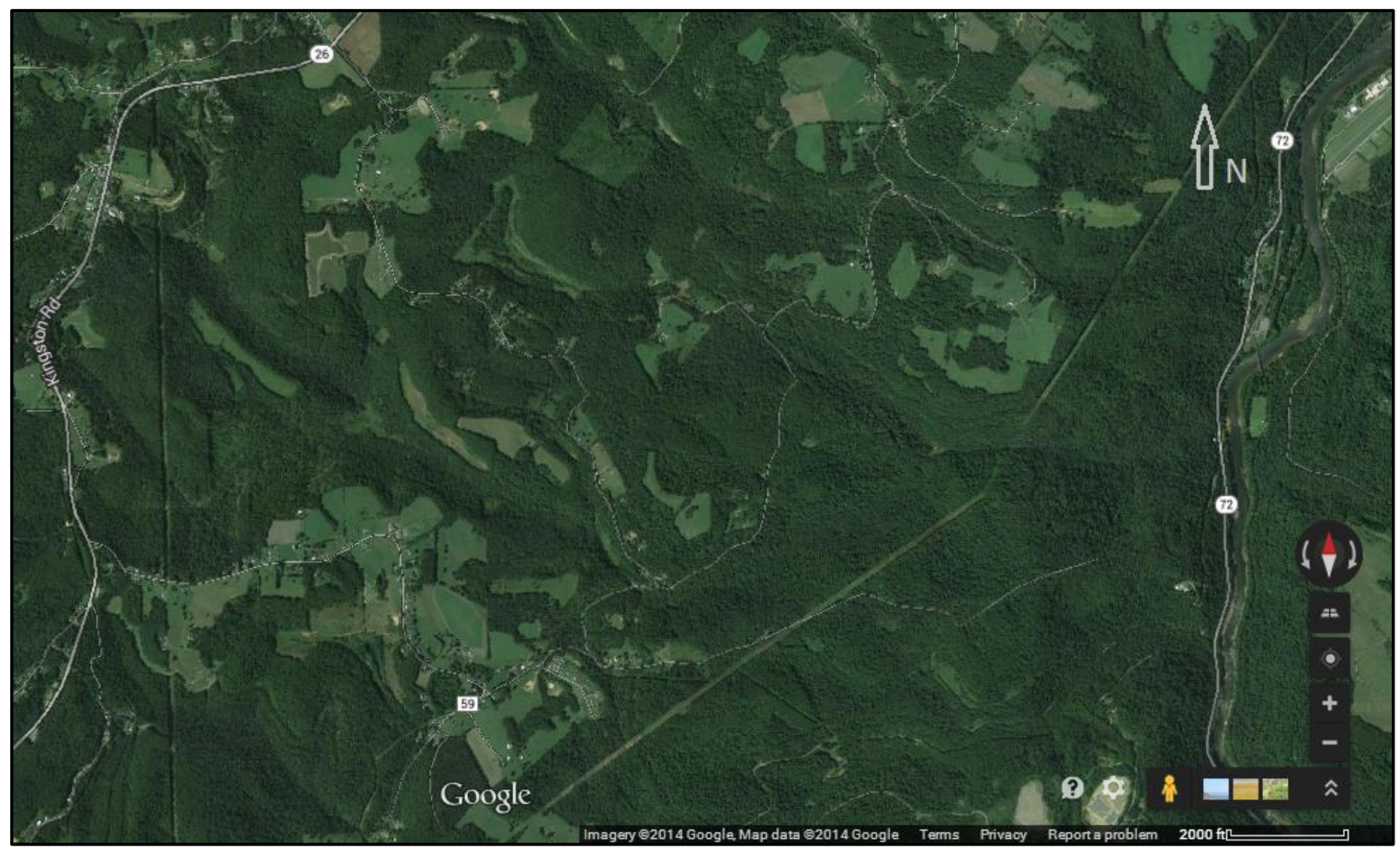

Figure 3: High definition image of the Lick Run watershed and surrounding area provided by Google Maps. Scale bar $=2000$ feet.

\subsubsection{Watershed Boundaries}

According to the 2011 Cheat River TMDL, Lick Run's specific watershed is considered to be a TMDL subwatershed of the Cheat River; which is even further subdivided into five Lick Run specific subwatersheds, of which will not be analyzed in this report. The 12 digit Hydrologic Unit Code (HUC) that includes Lick Run is 050200040702 and is referred to as the Pringle Run-Lower Cheat River watershed; this HUC covers Lick Run, Pringle Run, Heather Run, and Morgan Run, among others. The Ancode for Lick Run is WVMC-25; the NHD code is WV-MC-54. Lick Run will 
be studied and analyzed within its specific, fully encompassing watershed as denoted by red in Figure 4; it will simply be referred to as the "Lick Run" watershed (Tetra Tech 2011).

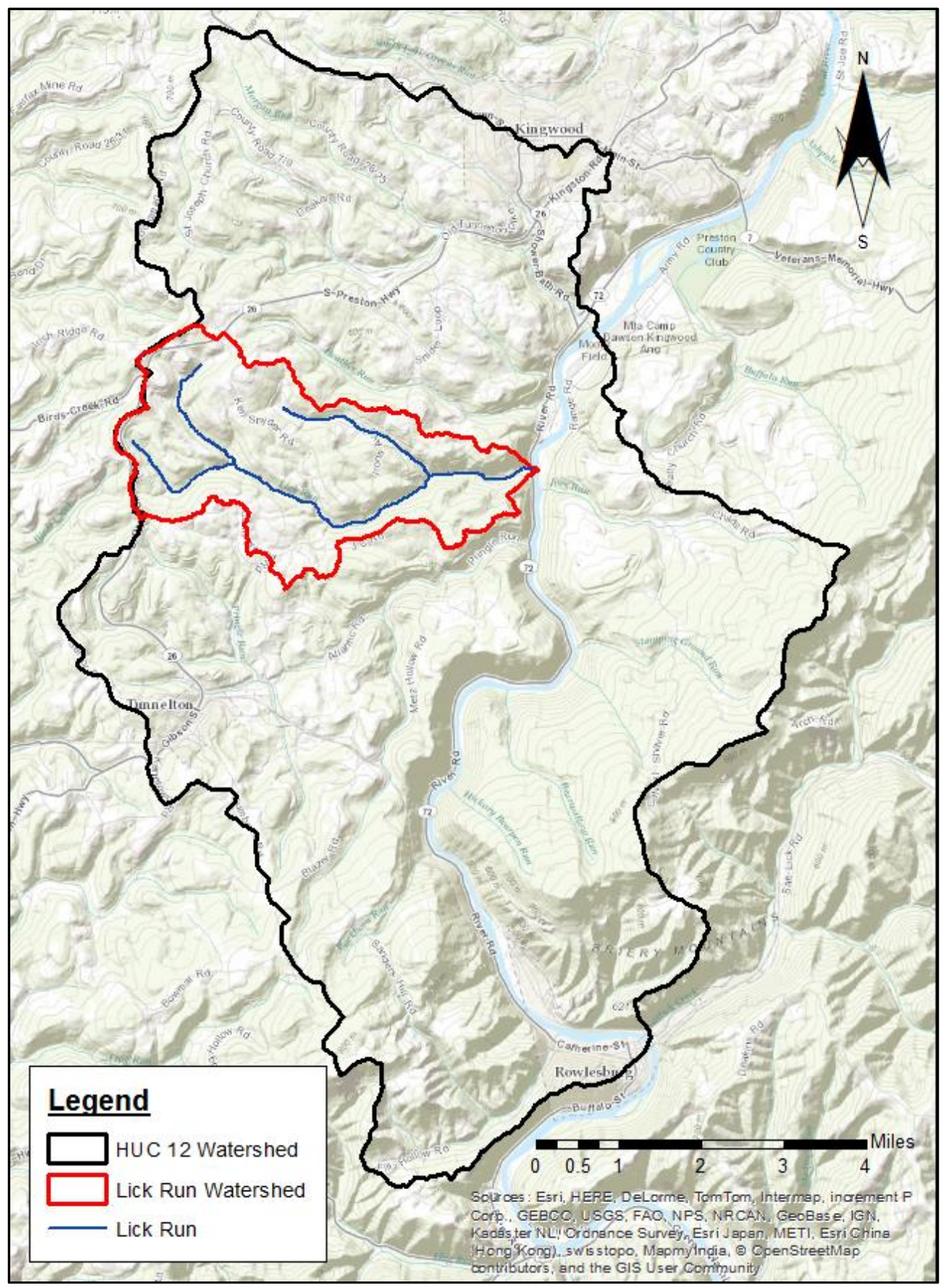

Figure 4: Lick Run watershed and its encompassing HUC 12 watershed. This figure also highlights Lick Runs stream path.

The following, Figure 5, shows a low definition imagery map of the Lick Run watershed. This figure includes Lick Run's watershed boundary and hydrology. All data and sources for Figures 4 and 5 came from the West Virginia Geographic Information Systems Technical Center (WVGISTC) (WVGISTC 2014). 


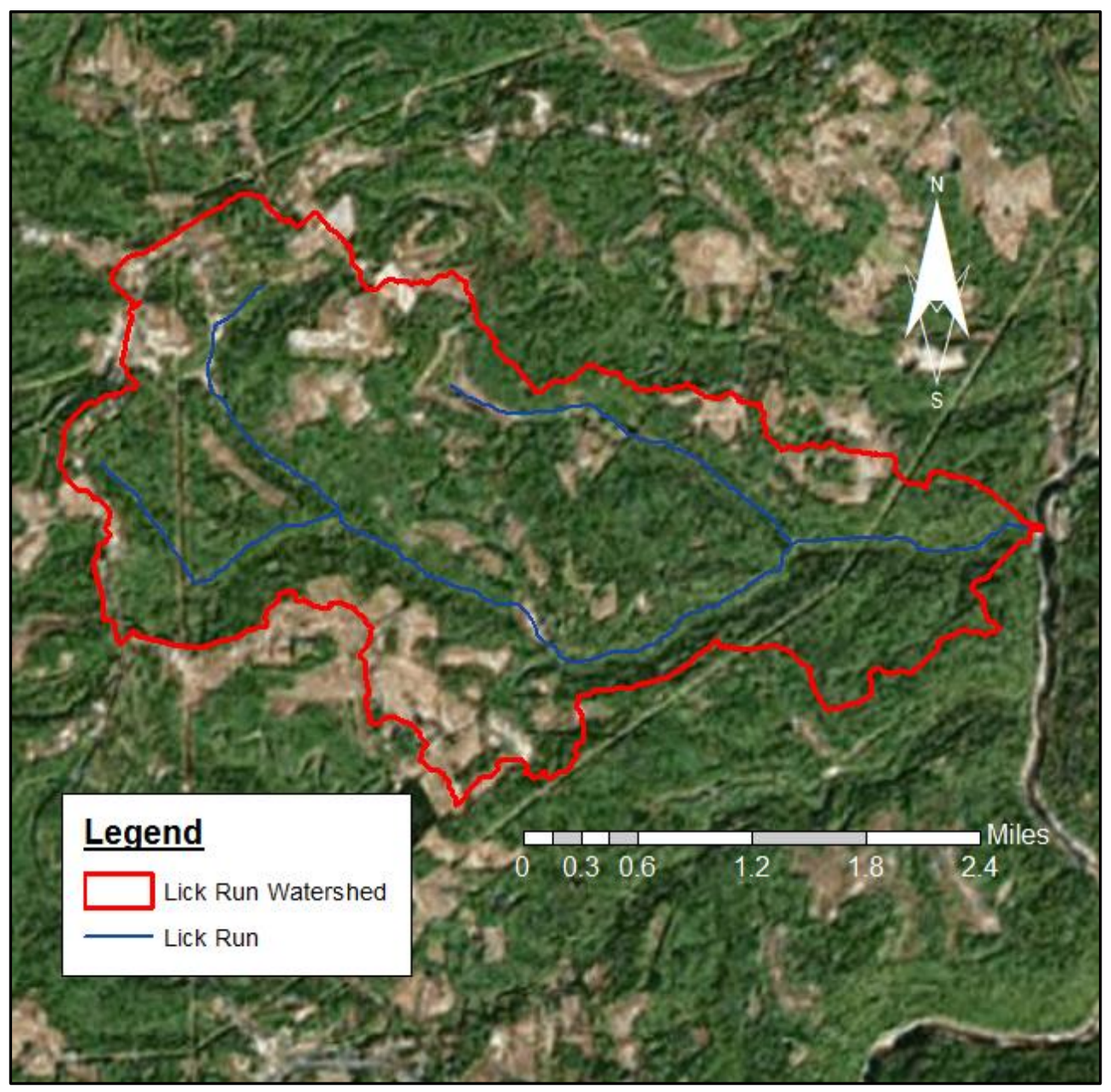

Figure 5: Low definition imagery of the Lick Run watershed and stream path.

\subsubsection{Hydrology}

Lick Run is an ungauged, directly draining tributary to the Cheat River. Because it is ungauged, no continuous flow data, including base flow, storm flow, or flashiness, currently exist. However, stream flow was measured during the four sampling events; this data will be reviewed later in this report. The research team also talked with members of local communities within the watershed to determine hydrologic characteristics. An unmarked tributary was found as a result of these interviews; it is referred to as Trib 1, and its mouth is located midway through Lick Run's mainstem, between the top and bottom forks.

The mainstem of Lick Run can be described as a moderately entrenched stream with low to moderate channel sinuosity. Sinuosity decreases from the headwaters to the mouth, and the upper region has a small, but well defined floodplain. The average slope from the highest point (Southern Start Tributary) to the discharge is about $2.7 \%$ with about a $793 \mathrm{ft}$. elevation change, over a distance of about 5.562 miles. The channel slope is highest from the Middle Start Tributary 
headwaters to the Bottom Fork (approx. 4.2\%). The slope decreases as it makes its way to the mouth; from the Bottom Fork to its discharge into the Cheat River, the slope is roughly $0.04 \%$ (Terrain Navigator, version 8.71 2010). Frequently, this low gradient section at the very end is back flooded by the Cheat River. Evidence of this is seen by the iron buildup on the bridge supports and boulders resting in Lick Runs mouth.

Lick Runs creek bed is predominately cobbles and sediment. However, as the stream approaches its confluence with the Cheat River, larger rocks and boulders are often found within the stream channel; this is especially true at the mouth. Small waterfalls expose the little amount of visible bedrock throughout.

Although the overwhelming majority of Lick Run has similar physical characteristics, water chemistry varies significantly, especially at the AMLIS designated Lick Run Portal \#4 site. This site attributes the majority of AMD impacts from legacy coal mining in Lick Run; it contains at least two separate portals, with a possible third or more, located well within half of a square mile. All of the Lick Run \#4 portals drain to the same place, around the Bottom Fork.

There are no navigable channels, ports, harbors, dams, or impoundments in Lick Run. Stream path flow is too low and watershed boundaries are too small to be a viable option for transportation or for the production of reasonable amounts of potable water. The majority of potable water that is supplied throughout Lick Run's watershed is provided by the Kingwood water treatment facility. Small personal wells are also used throughout this area.

\subsubsection{Climate and Precipitation}

Typically, weather conditions in the north-eastern region of central West Virginia has a somewhat consistent pattern. Precipitation levels are fairly consistent but vary slightly by month; temperature levels, on the other hand, follow a typical seasonal pattern. Climate information in the Lick Run watershed, Kingwood, and surrounding area is monitored by the Terra Alta Number 1 station, located about 7.5 miles northeast of the mouth of Lick Run, across the Cheat River, in Preston County. Climate data is based off on a 19 year time period from between 1981-2010 (NOAA 2010).

This area sees an average of 55.62 in. of precipitation annually, mostly occurring during the summer season (June - August) with 16.02 inches. October is generally the driest month of the year (3.41 in.), while July tends to be the wettest ( $6.32 \mathrm{in.}$.). The average, annual high temperature of the watershed is $58^{\circ} \mathrm{F}$; the average, annual low temperature of the watershed is $40.2^{\circ} \mathrm{F}$ (NOAA 2010). 


\subsubsection{Surface Water Resources}

Surface water resources within the Lick Run watershed consist of Lick Run and its three tributaries known as the Northern Start Tributary, Southern Start Tributary, and the newly found, unmarked and unnamed tributary, that is referred to as Trib 1. Lick Run's manstem and the Southrn Start Tributary extend the furthest upstream, their confluence come together to form the Top Fork. The Middle Start headwaters begin further through the watershed and flow into the mainstem at the Bottom Fork. Trib 1's confluence is located midway between the Top and Bottom Forks.

There are no natural lakes, man-made settling ponds, reservoirs, impoundments, or surface water intakes within Lick Run's watershed. Lick Run sits in an area that is very rural with many high hills. The small town of Howesville, located in the headwaters of Lick Run, is the only town within the watershed. The majority of the watersheds potable water comes from the Kingwood Water Treatment Facility, the rest come from small personal wells. At the Lick Run \#4 site, AMD water from portal 2 is efficiently mushrooming its way from its emergence into the local stream path that it follows. This mushrooming phenomenon is effectively causing the area in front of portal 2 to pond over with high amounts of visible AMD contamination.

\subsubsection{Ground Water Resources}

There are no documented springs within the Lick Run watershed. Undocumented springs may exist, but none were found during any of the sampling events, or the initial stream walk. There are also no large groundwater intakes that serve a large population, however, some of the residents in the watershed rely on private groundwater wells for their drinking water.

Most coal mining occurred around the Bottom Fork, this includes the Lick Run \#4 site. Additional mining was performed closer to the headwaters of Lick Run, around the small coal town of Howesville. Because of this, Lick Run's groundwater has potential impacts on groundwater wells throughout its length. The 2011 Cheat River TMDL shows that all of Lick Run is impaired by metals apart from the Southern Start Tributary (Tetra Tech 2011). Some nonpoint source locations indicate that the Southern Start headwaters may in fact be affected by AMD, but perhaps not to the same degree as the rest of Lick Run.

\subsubsection{Flood Plains}

There are no designated flood zones in the Lick Run watershed, however, there is a major designated floodplain within the Pringle Run-Lower Cheat River, HUC 12 watershed, which includes Lick Run (Figure 6). This floodplain is a 100 year flood event and is often referred to as a special flood hazard area (SFHA), which has a $26 \%$ chance of flooding over the life of a 30 -year 
mortgage. This data set is based on the National Flood Hazard Layer (NFHL), is made available through the Federal Emergency Management Agency (FEMA), and was compiled by the WVGISTC (WVGISTC 2014). It can be seen that the flooding limits are located entirely along the Cheat River. Lick Run's mouth is partially within this area; this is evident by the water stains that have been left on the bridge supports and boulders within it (Figure 43).

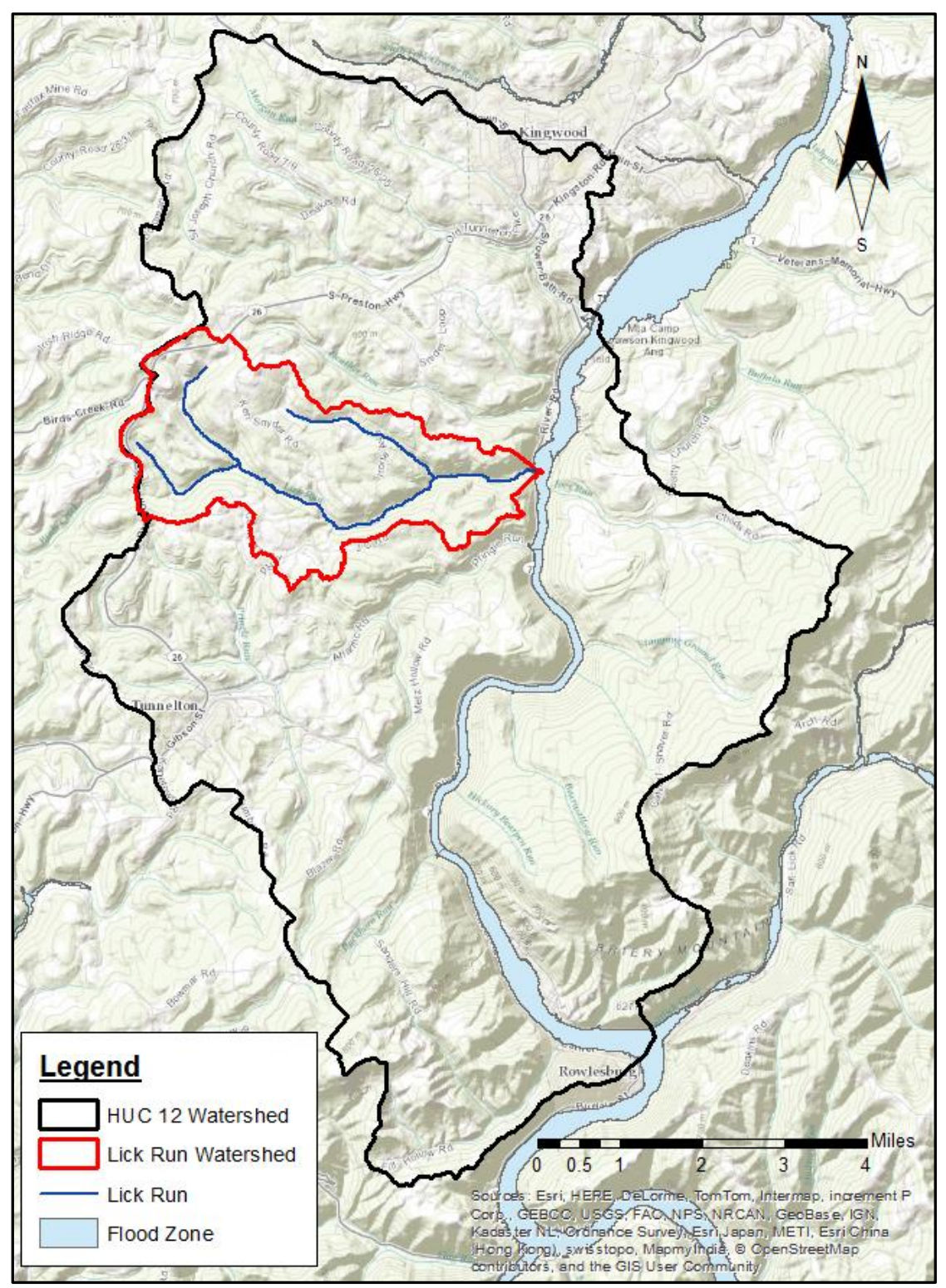

Figure 6: FEMA Flood Hazard Risk in Lick Run. The dark blue lines show Lick Runs stream path, areas shaded light blue is the estimated 100 year floodplain. 


\subsubsection{Topography/ Elevation}

Lick Run originates at an elevation of about 2,049 feet above mean sea level (msl) and drops approximately $793 \mathrm{ft}$. to enter the Cheat River at an elevation of about 1,256 ft. msl, according to Terrain Navigator, version 8.71 (2010). The highest elevation within the Lick Run watershed is $2349.5 \mathrm{ft}$. msl; the lowest elevation within the watershed is $1252.4 \mathrm{ft}$. msl. Figure 7 shows a digital elevation model of the Lick Run watershed and its surrounding area (WVGISTC 2014).

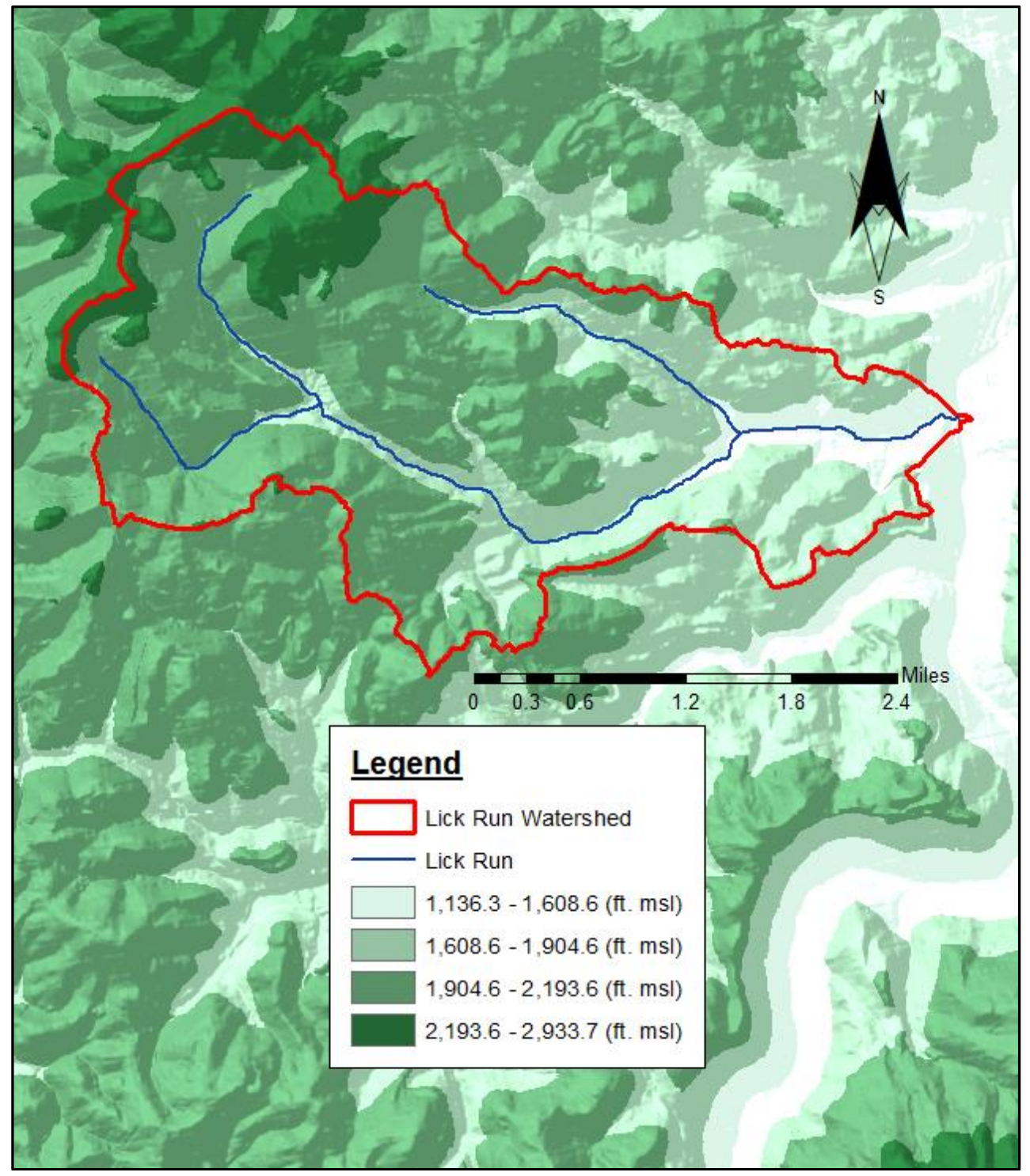

Figure 7: Digital Elevation Model of the Lick Run watershed. Higher elevations are shown in dark green and lower elevations are shown in lighter green/ white. Elevation values are given in feet above Mean Sea Level (msl). 


\subsubsection{Geology and Soils}

The majority of rocks that outcrop in West Virginia are Paleozoic in age. In Preston County, the rocks that outcrop mostly belong to the same period and system, the Pennsylvanian period of the Carboniferous system. These outcrops can be further classified to be principally made up of the Conemaugh and Allegheny geologic groups. The oldest formation documented in the Lick Run watershed area is the Allegheny formation; the youngest formation documented is the Monongahela formation (Patton et al. 1959).

Lick Run's watershed lies within the Northern Appalachian Coal Basin. Throughout the watershed, the Upper Freeport coal seam, which was created by the Allegheny group, has been mined extensively. The majority of the mining performed was underground mining, some surface mining also occurred (WVDEP TAGIS 2014). Allegheny coals are generally 2-6 ft. thick and aerially extensive. The Freeport coal seam is located at a maximum depth of $1,800 \mathrm{ft}$. below the ground surface (USEPA 2004). This coal seam was the most valuable mineral resource within the Lick Run watershed.

Preston County possesses six major soil associations; the only soil association that is found throughout the Lick Run watershed is the Gilpin-Rayne-Wharton association. "The soils of this area are principally from the Conemaugh and Allegheny geologic series and were derived from acid sandstone, siltstone, and clay shale. Slopes are often steep and sometimes rugged. Even so, the topography over most of this area is relatively smooth, particularly on the rounded hills and broad level ridge tops." (Patton et al. 1959)

The dominant soils in the Gilpin-Rayne-Wharton association include Gilpin, Rayne, Wharton, and Cavode. Gilpin and Rayne soils drain well, whereas Wharton is a moderately well-drained soil, and Cavode is a moderately poor-drained soil. Associated with these upland soils are the Ernest, Brinkerton, and Lickdale soils on the lower slopes, and the Pope, Philo, and Atkins soils in the narrow bottom lands and valleys. Soils of the Dekalb series are also present on some of the steep hillsides where the parent material is mainly massive sandstone (Patton et al. 1959).

A recent soil survey of the Lick Run watershed (Figure 8) shows the following results. Data was obtained from the United Sates Department of Agriculture's (USDA's)/ National Resources Conservation Service's (NRCS's) web soil survey (USDA NRCS 2013). This survey's spatial and tabular data for Preston County, WV was last updated on December 26, 2013 and was obtained for use on August 22014. 


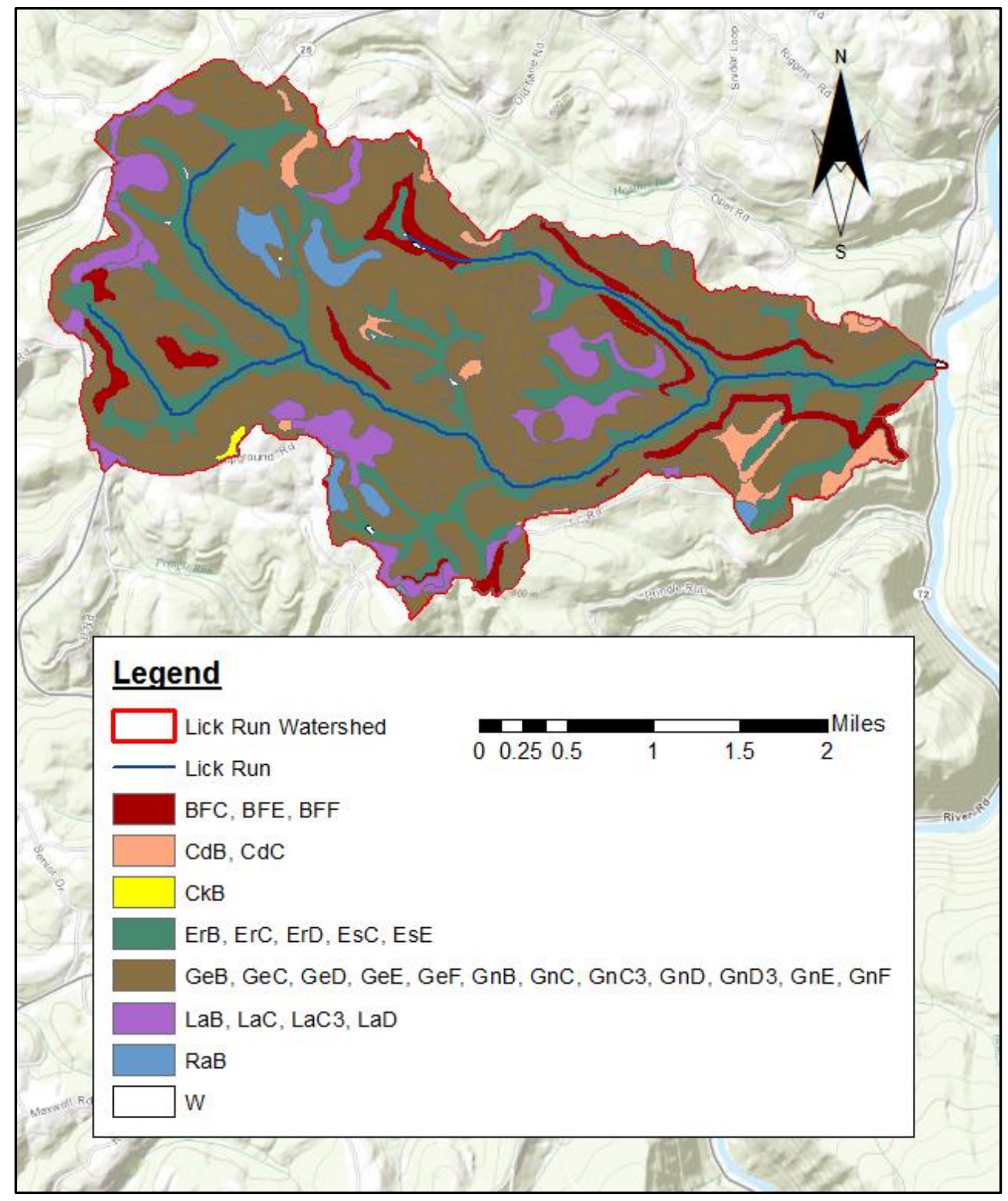

Figure 8: General soil types in the Lick Run watershed, this figure goes with Table 1. 
Table 1: General soil types in the Lick Run watershed, this table goes with Figure 8.

\begin{tabular}{|c|c|c|c|}
\hline \multicolumn{4}{|l|}{ General Lick Run Soil Analysis } \\
\hline Group & Soil & Area & Percentage \\
\hline All & All & 0.001328 & 100 \\
\hline BFC,BFE,BFF & Bethesda and Fairpoint & 0.000082 & 6.2 \\
\hline $\mathrm{CdB}, \mathrm{CdC}$ & Cavode & 0.00004 & 3.0 \\
\hline $\mathrm{CkB}$ & Clymer & 0.000002 & 0.2 \\
\hline $\mathrm{ErB}, \mathrm{ErC}, \mathrm{ErD}, \mathrm{EsC}, \mathrm{EsE}$ & Ernest & 0.000276 & 20.8 \\
\hline $\begin{array}{l}\mathrm{GeB}, \mathrm{GeC}, \mathrm{GeD}, \mathrm{GeE}, \mathrm{GeF}, \mathrm{GnB}, \mathrm{GnC}, \mathrm{GnC}, \mathrm{GnD}, \\
\mathrm{GnD} 3, \mathrm{GnE}, \mathrm{GnF}\end{array}$ & Gilpin & 0.000799 & 60.2 \\
\hline LaB, LaC, LaC3, LaD & Latham & 0.0001 & 7.5 \\
\hline $\mathrm{RaB}$ & Rayne & 0.000029 & 2.2 \\
\hline W & Water & 0 & 0 \\
\hline
\end{tabular}

As can be seen by Figure 8 and Table 1 above, Lick Run's watershed is predominantly made up of Gilpin and Ernest soils. Gilpin is the original, native soil that was and still is exposed. Lick Run's hydrology has uncovered the majority of Ernest soil. Surface mining exposed most, if not all, of the Bethesda and Fairpoint soils. The rest of the soils became present due to mining, development, agriculture, and/ or natural occurrence. No Wharton soil and very little Rayne soil is present/ exposed in the Lick Run watershed.

An even more detailed soil survey is presented below (Figure 9 and Table 2). This data came from the same source as the above soil survey but offers details such as slope percentages, grain size distribution, and texture (USDA NRCS 2013). 


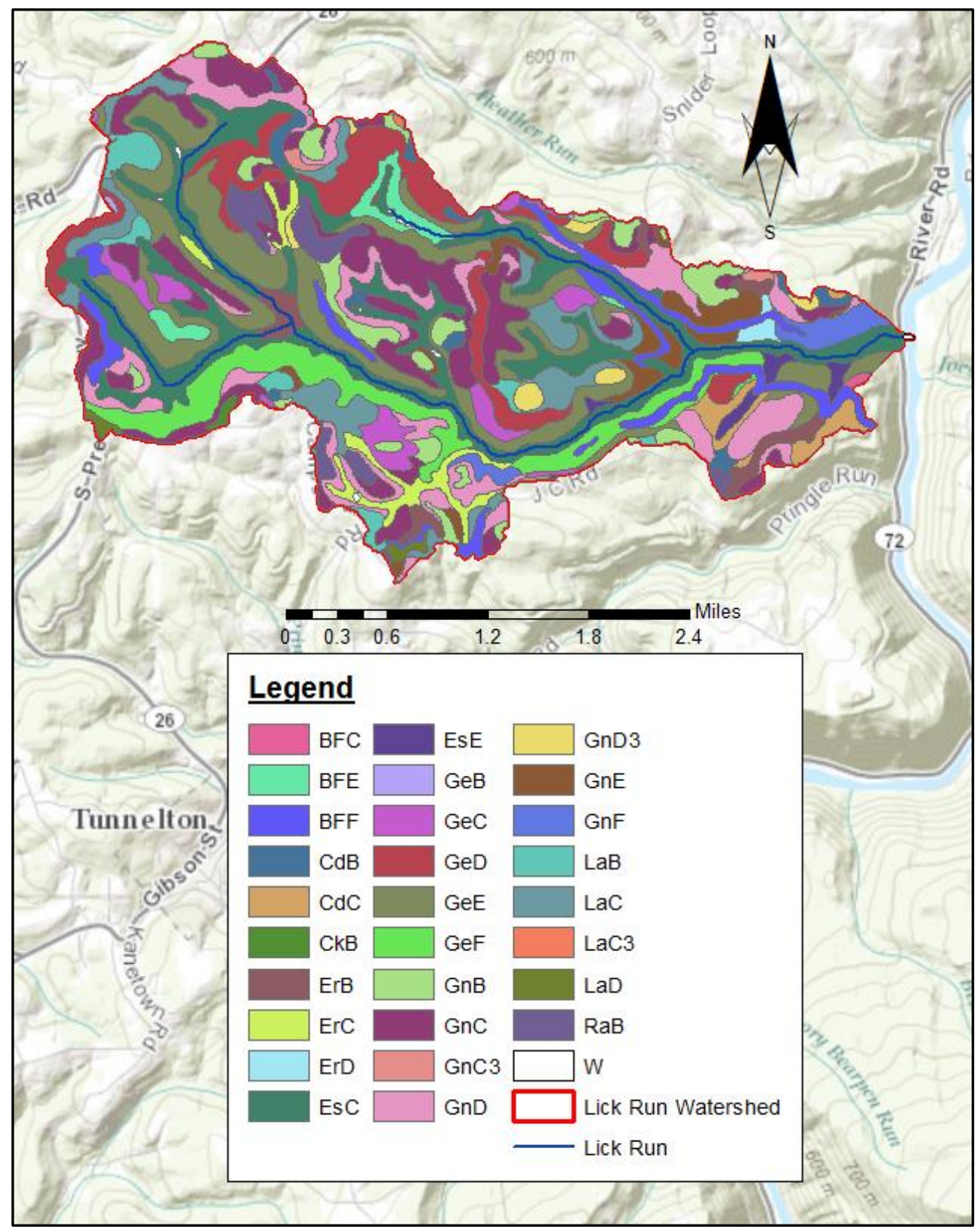

Figure 9: Detailed soil types in the Lick Run watershed, this figure goes with Table 2. 
Table 2: Detailed soil types in the Lick Run watershed, this table goes with Figure 9.

\begin{tabular}{|c|c|c|c|}
\hline \multicolumn{4}{|c|}{ Detailed Lick Run Soil Analysis } \\
\hline Group & Soil & Area & Percentage \\
\hline All & All & 0.001328 & 100 \\
\hline $\mathrm{BFC}$ & Bethesda and Fairpoint soils, 0 to 15 percent slopes & 0.000001 & 0.1 \\
\hline BFE & Bethesda and Fairpoint soils, 15 to 35 percent slopes & 0.000022 & 1.7 \\
\hline BFF & Bethesda-Fairpoint-Rock outcrop association, very steep & 0.000059 & 4.4 \\
\hline $\mathrm{CdB}$ & Cavode silt loam, 3 to 8 percent slopes & 0.000019 & 1.4 \\
\hline $\mathrm{CdC}$ & Cavode silt loam, 8 to 15 percent slopes & 0.000021 & 1.6 \\
\hline $\mathrm{CkB}$ & Clymer gravelly loam, 3 to 8 percent slopes & 0.000002 & 0.2 \\
\hline ErB & Ernest silt loam, 3 to 8 percent slopes & 0.000026 & 2.0 \\
\hline $\mathrm{ErC}$ & Ernest silt loam, 8 to 15 percent slopes & 0.000027 & 2.0 \\
\hline ErD & Ernest silt loam, 15 to 25 percent slopes & 0.000005 & 0.4 \\
\hline $\mathrm{EsC}$ & Ernest silt loam, 3 to 15 percent slopes, extremely stony & 0.000208 & 15.7 \\
\hline EsE & Ernest silt loam, 15 to 25 percent slopes, extremely stony & 0.00001 & 0.8 \\
\hline GeB & Gilpin channery silt loam, 3 to 8 percent slopes, extremely stony & 0.000001 & 0.1 \\
\hline $\mathrm{GeC}$ & Gilpin channery silt loam, 8 to 15 percent slopes, extremely stony & 0.000037 & 2.8 \\
\hline GeD & Gilpin channery silt loam, 15 to 25 percent slopes, extremely stony & 0.000095 & 7.2 \\
\hline $\mathrm{GeE}$ & Gilpin channery silt loam, 25 to 35 percent slopes, extremely stony & 0.000192 & 14.5 \\
\hline GeF & Gilpin channery silt loam, 35 to 65 percent slopes, extremely stony & 0.000083 & 6.3 \\
\hline GnB & Gilpin silt loam, 3 to 8 percent slopes & 0.000052 & 3.9 \\
\hline GnC & Gilpin silt loam, 8 to 15 percent slopes & 0.000148 & 11.1 \\
\hline GnC3 & Gilpin silt loam, 8 to 15 percent slopes, severely eroded & 0.000004 & 0.3 \\
\hline GnD & Gilpin silt loam, 15 to 25 percent slopes & 0.000118 & 8.9 \\
\hline GnD3 & Gilpin silt loam, 15 to 25 percent slopes, severely eroded & 0.000013 & 1.0 \\
\hline GnE & Gilpin silt loam, 25 to 35 percent slopes & 0.000036 & 2.7 \\
\hline GnF & Gilpin silt loam, 35 to 65 percent slopes & 0.00002 & 1.5 \\
\hline LaB & Latham silt loam, 3 to 8 percent slopes & 0.000025 & 1.9 \\
\hline $\mathrm{LaC}$ & Latham silt loam, 8 to 15 percent slopes & 0.000069 & 5.2 \\
\hline LaC3 & Latham silt loam, 8 to 15 percent slopes, severely eroded & 0.000001 & 0.1 \\
\hline LaD & Latham silt loam, 15 to 25 percent slopes & 0.000005 & 0.4 \\
\hline $\mathrm{RaB}$ & Rayne silt loam, 3 to 8 percent slopes & 0.000029 & 2.2 \\
\hline W & Water & 0 & 0 \\
\hline
\end{tabular}

\subsection{Land Use and Land Cover}

The primary land use/ cover in the Lick Run watershed is forested. Of this forested area (roughly $84 \%$ ), all of it is expected to be cool, temperate, deciduous forest (USGS 2014c). Apart from this, over $11 \%$ of Lick Run's watershed is used for grasslands, pasturelands, and/ or agricultural lands; 
most of which is used as grasslands and pasturelands for grazing farm animals. The rest of the watershed is made up of barren and developed area; most of this area is occupied by the 2011 Census Road at about $2.5 \%$ coverage. Apart from the census road, very little of Lick Run's watershed is developed, so most of this area is expected to be barren (less than $2 \%$ ), and the barren lands of the watershed are likely mining-impacted. Figure 10 and Table 3 show a detailed analysis of land use and cover within the Lick Run watershed; this data was obtained from the WVGISTC and is relative to 2011 growing season (WVGISTC 2014).

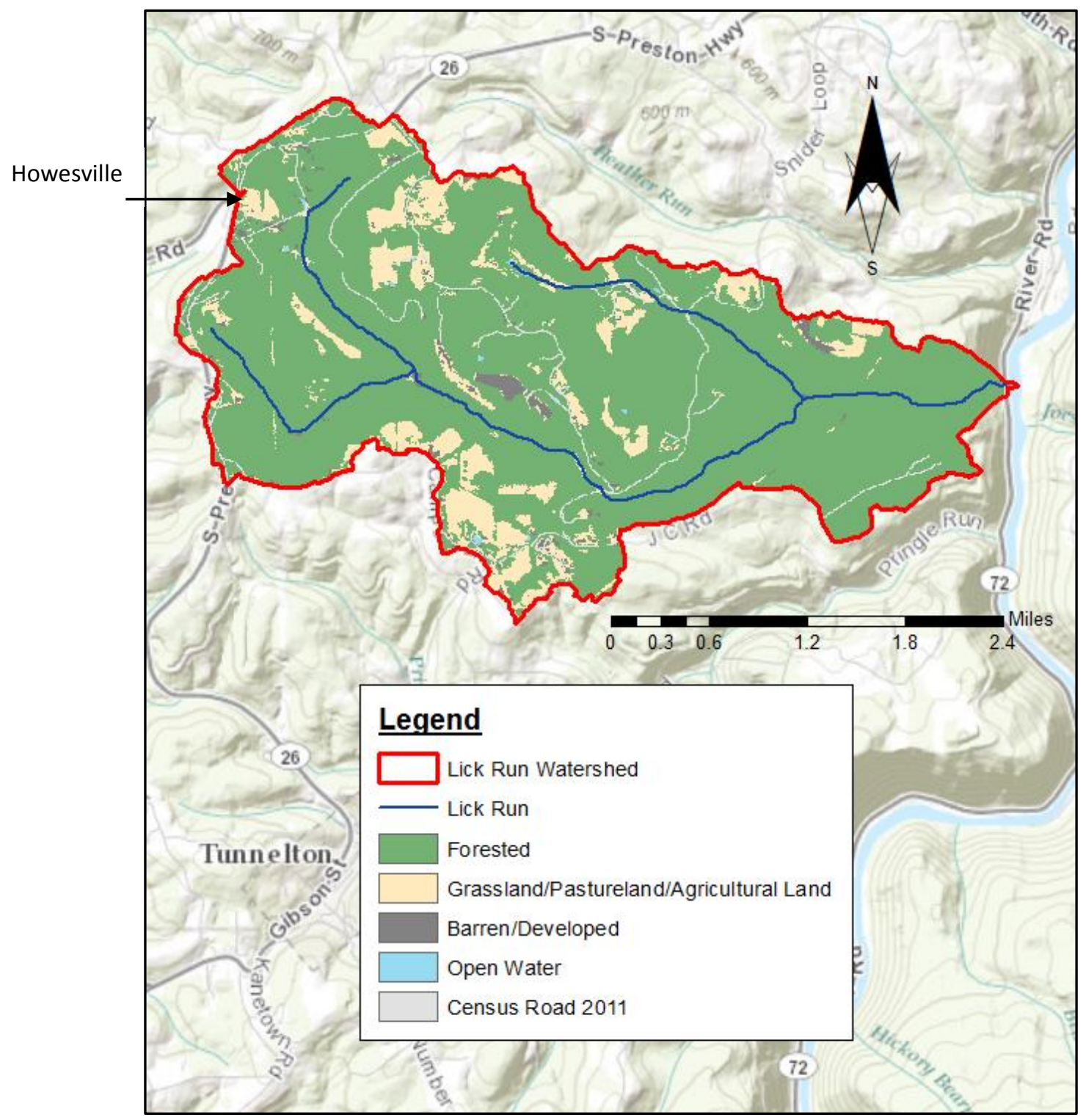

Figure 10: Land use/ land cover map. This figure goes with Table 3. 
Table 3: Land use/ land cover categories and percentages. This table goes with Figure 10.

\begin{tabular}{|l|c|}
\hline \multicolumn{2}{|c|}{ Lick Run Land Use Analysis } \\
\hline Value & Percent \\
\hline Forested & 84.2 \\
\hline Grassland/ Pastureland/ Agricultural Land & 11.4 \\
\hline Barren/ Developed & 1.8 \\
\hline Open Water & 0.2 \\
\hline Census Road 2011 & 2.5 \\
\hline \hline Total & 100.0 \\
\hline
\end{tabular}

\subsubsection{Open Space}

With the exception of the old, small coal mining town of Howesville (located in the headwaters of Lick Run), the Lick Run watershed has remained almost entirely rural in nature. According to Table 3, $1.8 \%$ of the watershed is barren or developed, most of which is mine barren and therefore open space. The grasslands, pasturelands, and agricultural lands account for over $11 \%$ of the watershed. These areas are predominantly used as grasslands and pasturelands with few crops, thus offer ample open space; much of this area is occupied by grazing cattle, horse, and/ or goats. The rest of the watershed is made up of forested area ( 84\%), roadway ( 2.5\%), and open water ( $0.2 \%)$. Development has occurred very slowly within the watershed, thus, the amount of open space is anticipated to stay relatively about the same for the foreseeable future.

\subsubsection{Wetlands}

The Lick Run watershed contains very little wetland territory. The land use analysis (Figure 10 and Table 3 ) show that only about $0.2 \%$ of the watershed contains open water. A more detailed wetland analysis is presented below; information was obtained from the WVGISTC and is based on the U.S. Fish and Wildlife Service (FWS) National Wetlands Inventory (NWI) data (WVGISTC 2014).

As can be seen in Figure 11, the Lick Run watershed has very little FWS recognized wetlands. The areas that are considered wetlands are all palustrine systems with unconsolidated bottoms. The Cheat River is considered riverine and also has an unconsolidated bottom (WVGISTC 2014). 


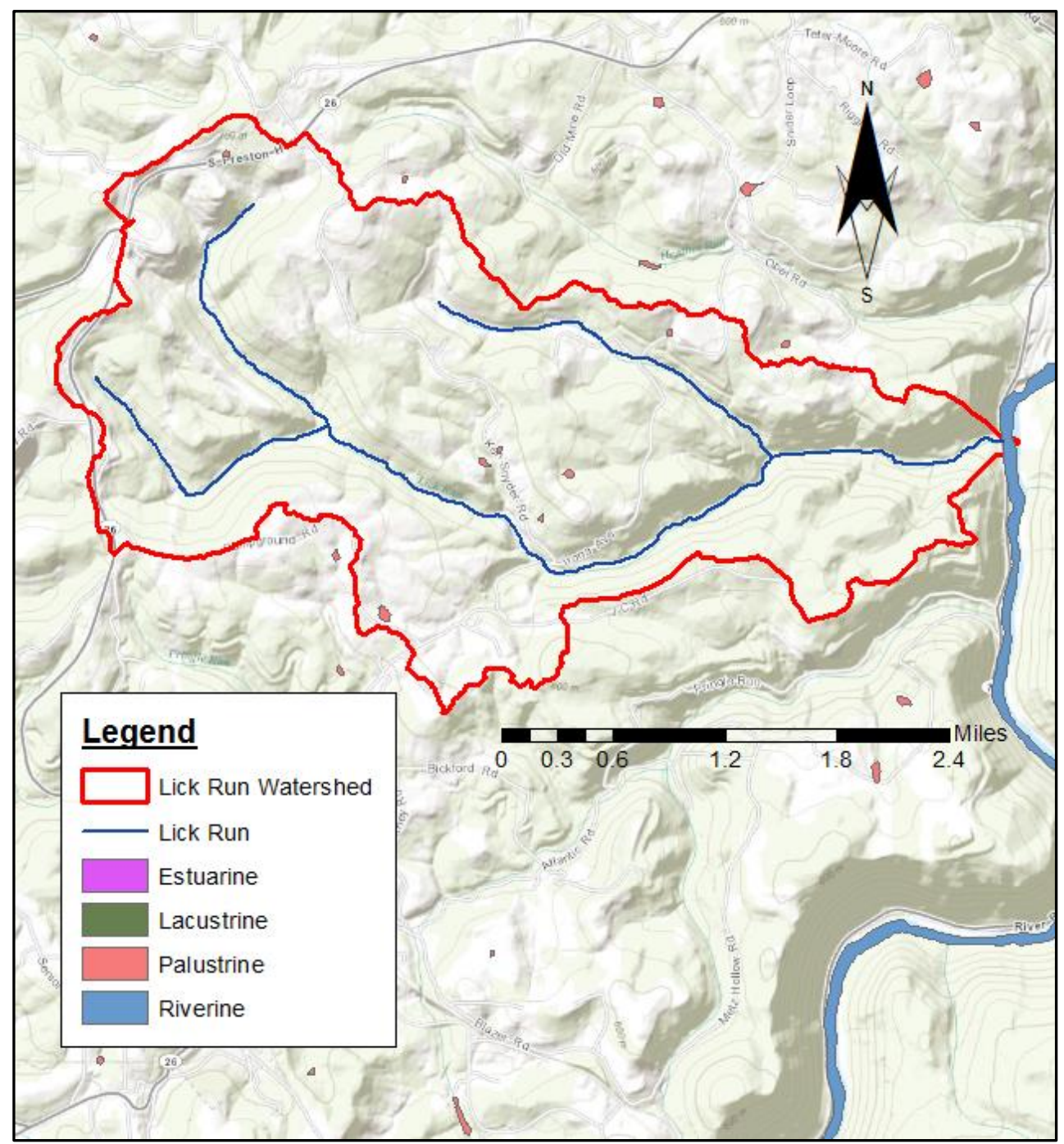

Figure 11: Wetlands in Lick Run, according to the National Wetlands Inventory (NWI).

\subsubsection{Forested Areas}

About $84 \%$ of the land area within the Lick Run watershed is deciduous forest. The most densely forested areas of the watershed occur around the bottom fork to the mouth. Grasslands and pasturelands are present sporadically throughout the upper portions of the watershed due to legacy coal mining and small farm/ residential properties. The central, southern watershed protrusion is the least forested area and is mostly used as grasslands and pasturelands, and perhaps, some agricultural lands. The northwestern edge of the watershed is less forested due to the small town of Howesville, Howesville's location within the watershed is shown in Figure 10 and Figure 18. 


\subsubsection{Agricultural Lands}

There are 1,084 farms in Preston County at an average size of 148 acres. Most farms within the county are cattle and calve farms or hay, haylage, grass silage, and greenchop farms; corn, hogs and pigs, and sheep and lamb farms are also present. The average value of a farm in Preston County is about $\$ 366,000$ and the average value of all machinery and equipment used on these farms is $\$ 56,000$ (USDA NASS 2012).

It is unknown exactly how many of these farms are within the Lick Run watershed, however, $11.4 \%$ of the watershed area is listed for possible agricultural use according to the WVGISTC (Table 3). Much of this area is used as personal farms with low amount of products being produced and sold, if any; these farmable areas are used more as grasslands and pasturelands for small populations of personal farm animal grazing use. Very little of Lick Runs watershed is used for crops, though, small, personal gardens are present at many of the private farms throughout the watershed. The central, southern protrusion of the watershed holds the highest chance for agricultural use due to its high amount of agriculturally usable land.

\subsubsection{Mining}

Coal was first discovered in what is now West Virginia in 1742. The peak of coal mining in West Virginia occurred during the late 1800s and early 1900s. Coal can be found within 53 of West Virginia's 55 counties, 43 of which contain minable reserves. There are 117 named coal seams in West Virginia, 65 of them are considered mineable. In 2012, more than half of the nation's electricity was generated from coal including 99\% of West Virginia's electricity. There were 14 coal fired electric generating facilities located in West Virginia at this time (MHS\&T 2012).

In 1990, West Virginia produced a total of $171,155,053$ tons of coal. Preston County accounted for 4,093,944 tons of this, over 1.5 million tons were surface mined, and over 2.5 million tons were produced from underground. In 2012, West Virginia produced a total of 129,538,515 tons of coal. Preston County contributed only 10,920 tons of this and all of it came from underground sources. During this time, Preston Counties coal production employees dropped from 724 in 1990 to 14 in 2012 (MHS\&T 2014a; MHS\&T 2014b).

Within the Lick Run watershed, the Upper Freeport Coal seam was mined extensively producing bituminous coal. The Upper Freeport coal seam was formed by the Allegheny group (formation) during the Pennsylvanian period of the Carboniferous system. The Freeport coal seam is split into two sections known as the Upper and Lower Freeport coal seams. They are separated by a distance of about 40 to 60 feet of mostly shale, and some sandstone (USEPA 2004). Available data indicate that the Upper Freeport ranges in thickness from 24 to 144 inches, and the thickest part of the coal bed is located in eastern Preston County (WVGES 2012). The average thickness of all Upper Freeport coal within WV is less than 6 feet (72 inches) (USEPA 2004). 
The Upper Freeport coal bed stretches across Pennsylvania, Ohio, Maryland, and West Virginia, and occupies more than 14,000 square miles. The Upper Freeport remains the third most productive coal bed in the region, and is the $14^{\text {th }}$ largest producer of coal in the United States despite declining production. Its coal is classified to be medium-ash and medium-sulfur with a high-calorific-value; this coal fails to meet current $\mathrm{SO}_{2}$ standards without blending or scrubbing. Less than 31 billion short tons (bst) of resources remain in the Upper Freeport coal seam, a total of 34 bst of coal was originally estimated to be available. Pods of coal remain under deep overburden 1,000 ft. to 2,000 ft. deep and are unlikely to be mined, relatively shallow resources remain in Pennsylvania and Ohio. In WV, the distance to the top of the Freeport coal seam is 0 to $1,600 \mathrm{feet}$ and the distance to fresh water is approximately $150 \mathrm{ft}$. to $500 \mathrm{ft}$. (USGS 2000b).

The following (Figure 12), shows the Upper Freeport coal seams extent throughout its four states coverage, its extent throughout the Lick Run watershed, and its extent throughout Lick Run's encompassing HUC 12 watershed. These data were made available by the USGS Appalachian basin coal assessment (USGS 2013) 


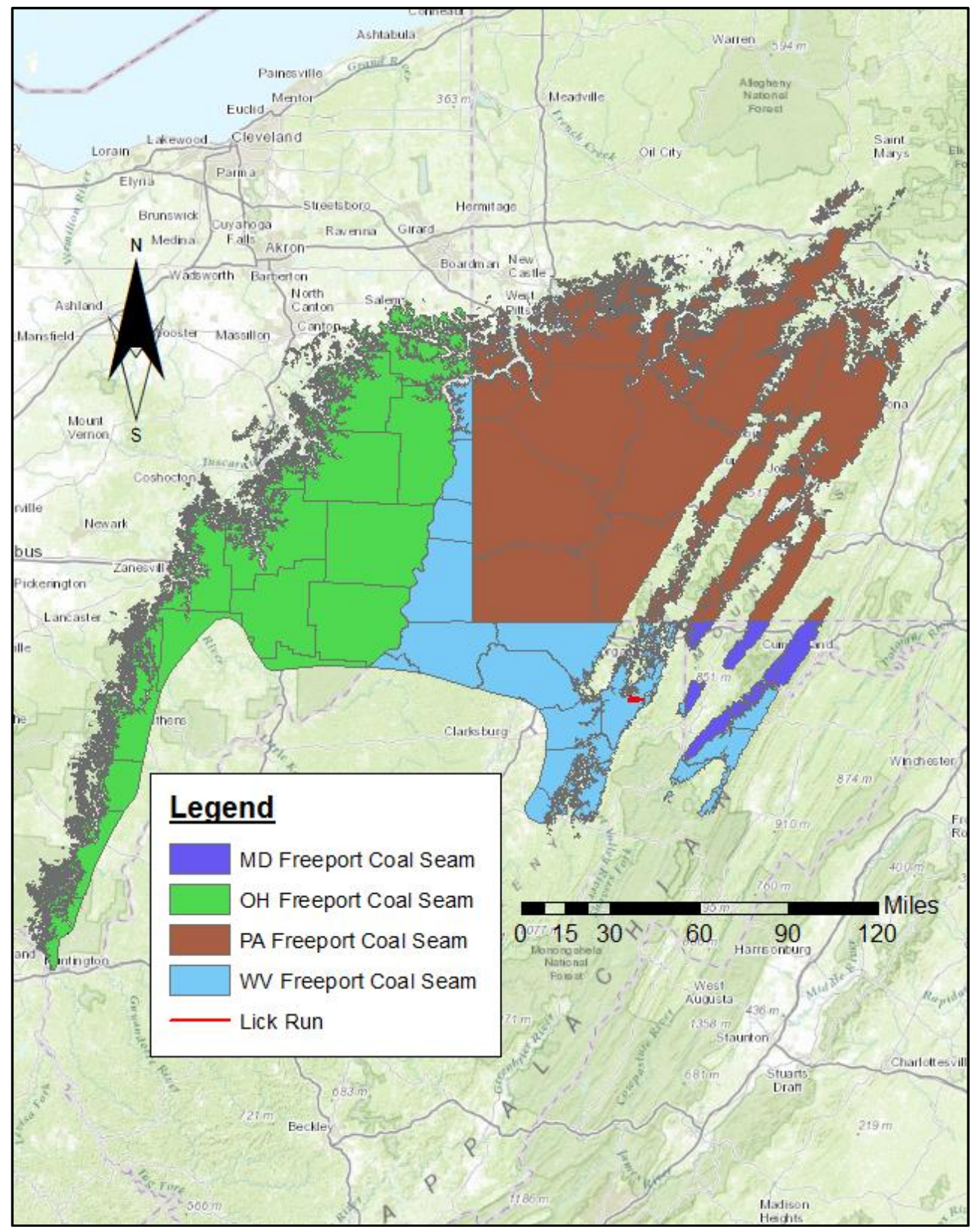

Figure 12: Full extent of the Upper Freeport Coal Seam.

Lick Runs entire watershed, apart from its mouth, falls on top of the Upper Freeport coal seam (Figure 13). Within this area, the majority of mining that occurred was underground mining, though surface mining also occurred (USEPA 2004). 


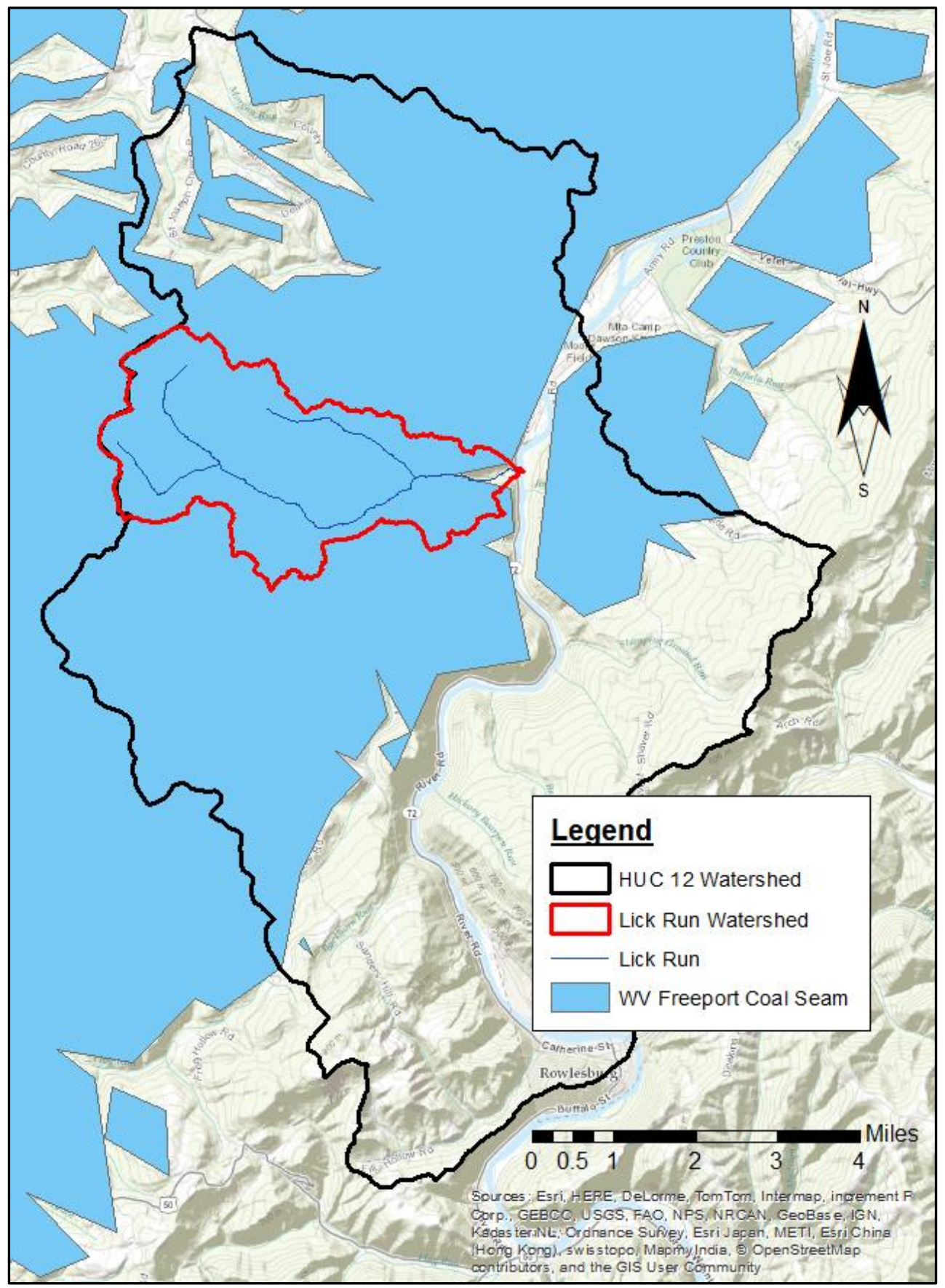

Figure 13: The Upper Freeport Coal Seam within Lick Runs watershed, and Lick Runs encompassing HUC 12 watershed.

The following three figures show the extent of underground mining and surface mining within the Lick Run watershed. Figure 14 shows underground mining extents within the Lick Run watershed. These data were created by the WVDEP and made available through the WVDEP Mining Data Explorer (WVDEP TAGIS 2014). The Lick Run watershed outline is not available for this map, but reference points are shown throughout. 


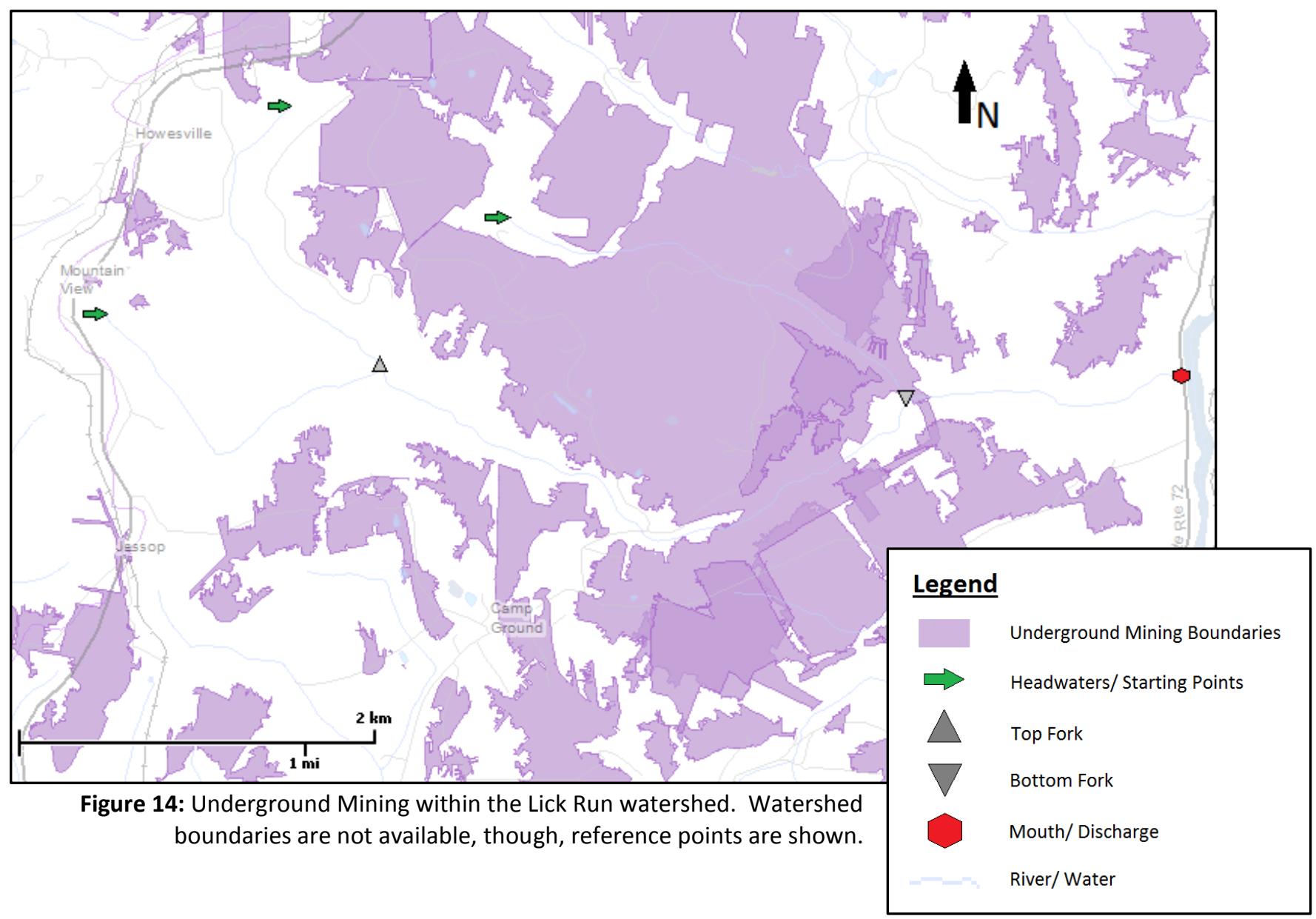

"Before World War II only a few small areas of iron ore and some coal were strip mined in Preston County. During World War II, strip mining of coal became an important industry. Approximately 2,500 acres [almost $4 \mathrm{mi}^{2}$ ] of land have been strip mined since 1940 (Patton et al. 1959)." World War II created a high demand for fuel and energy, the U.S. compensated for this by exploiting easy to reach surface and strip mines; these mines were excavated with little regard to the environment and marked the beginning of regulatory laws and limits for all forms of coal mining and its impacts left on the environment. The Surface Mining Control and Reclamation Act (SMCRA) was signed on August 3, 1977 to regulate the environmental effects of coal mining within the United States (OSMRE 2014).

Figures 15 and 16 are topographic maps of Lick Run's discharge and headwaters, respectively. These topographic maps are the best way to show Lick Runs surface and strip mining history and were broken into two separate maps for legibility purposes. All brown shaded areas and grainy purple areas are former surface and strip mine locations. These maps were pulled from the 'Kingwood map' from Terrain Navigator, version 8.71 (2010). The 'Kingwood map' was created in 2002 and uses $20 \mathrm{ft}$. contour intervals. The map scale for Figures 15 and 16 is 1:24,000. 


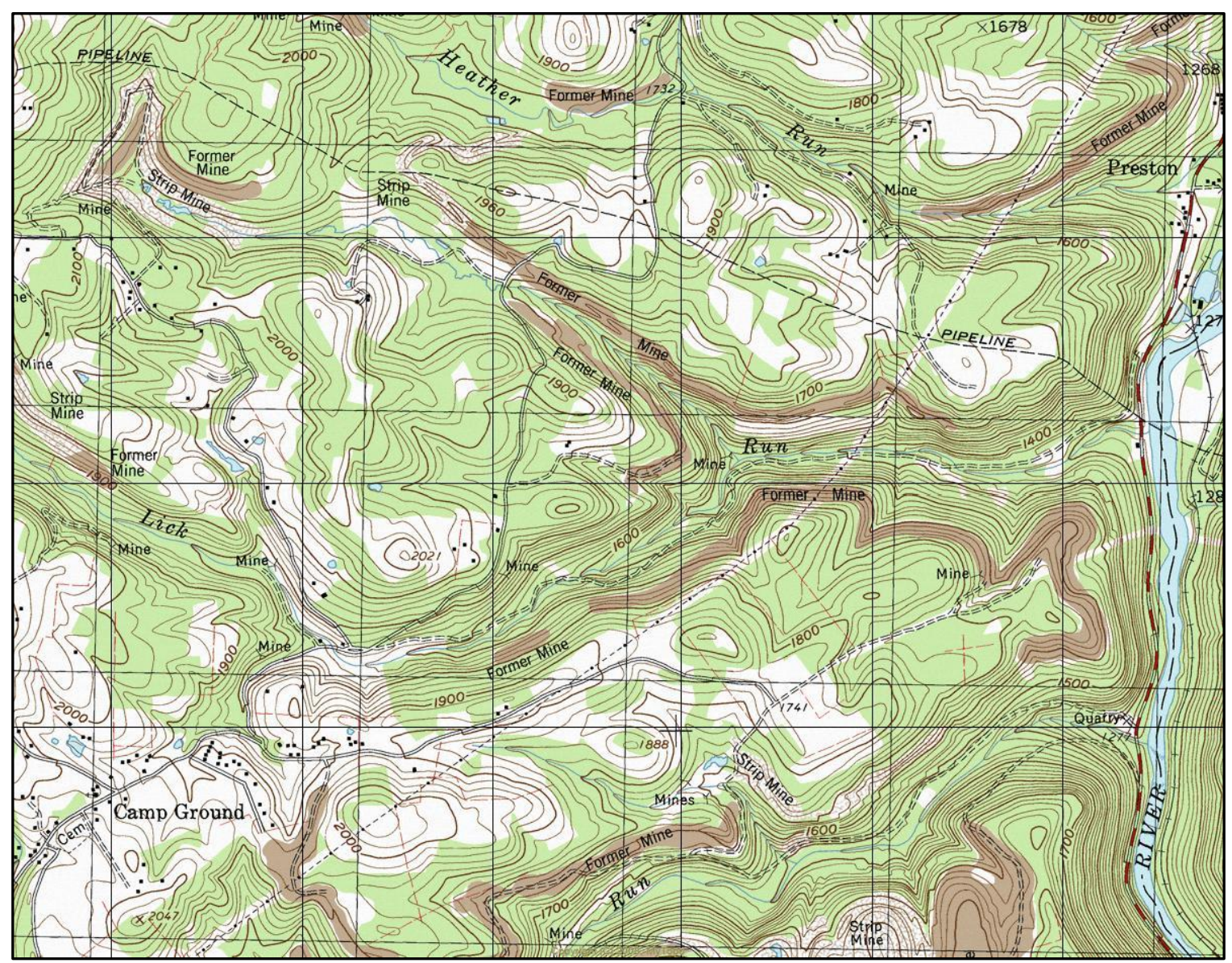

Figure 15: Topographic map of Lick Runs discharge into the Cheat River; the Bottom Fork is shown near the center of the map. Surface and strip mined areas are shown in brown and grainy purple. 


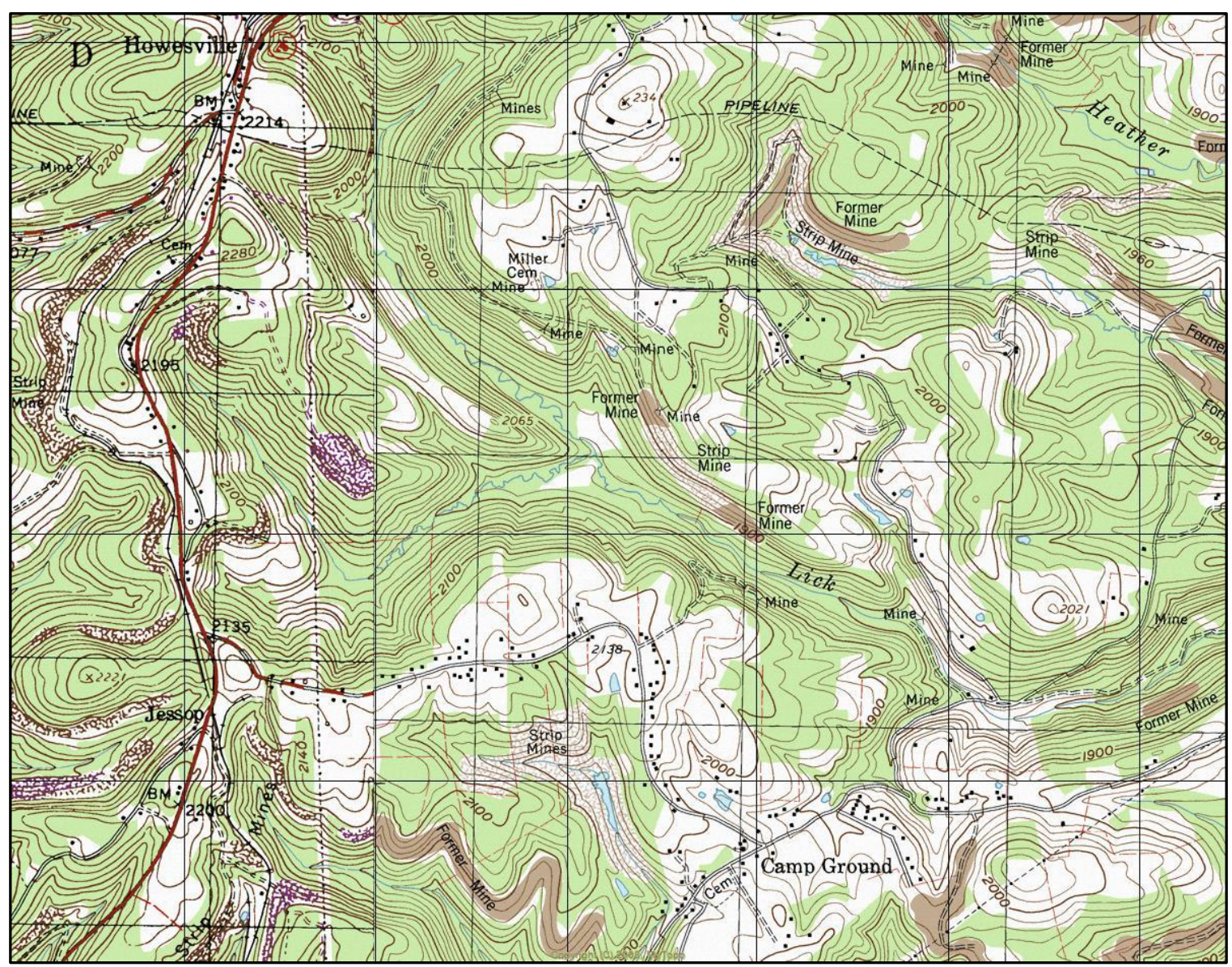

Figure 16: Topographic map of Lick Runs headwaters, the Top Fork is shown near the center of the map. Surface and strip mined areas are shown in brown and grainy purple.

The majority of all types of mining can be seen (Figures 14, 15 and 16) to have occurred around the Bottom Fork of Lick Run. This is also the location of the highest contributor of AMD to the watershed, known as the Lick Run \#4 site. This site has at least 3 open portals and visibly contributes the most contaminated water of all sources to the watershed.

Small amounts of the Bakerstown coal seam was mined under the Lick Run watershed, apart from the Upper Freeport (WVDEP TAGIS 2014). Some facts about the Bakerstown coal seam: The bed was formed in the Glenshaw Formation of the Conemaugh Group during the Pennsylvanian Period of the Carboniferous System. The Glenshaw formation overlies the Allegheny Formation and its total bed thickness generally ranges between 24 in. to 84 in. (WVGES 2012). The Bakerstown underground coal mines that have area within the Lick Run watershed are located in the lower lands of the watershed, closer to the mouth. "There have been no history of AMD problems with mining Bakerstown coal in this area due to the presence of red shale and limestone in its overburden." (Skousen and Larew 1992)

It is suspected that the Lick Run HW AMLIS site has portals into the Bakerstown coal seam, but this site is on the border of the Lick Run watershed and it is unknown if these portal(s) lie within the watershed or not. Other than this, only a couple of other Bakerstown coal mine portals could 
be within the Lick Run watershed, if at all. Because so little of this seam was mined in the Lick Run watershed, and because Bakerstown coal contributes small amounts of AMD, the Upper Freeport coal is the main focus of this report.

\subsubsection{Recreation}

Lick Run has a very small watershed and is itself a small tributary to the Cheat River. As such, Lick Run is not used for much recreational use. None of its waters are deep enough to support contact recreation, and no viable fish are known to spawn in, or swim into, the Lick Run watershed. Lick Run directly drains into the Cheat River, however, which does support contact recreation and fishing.

\subsubsection{Developed Areas}

The Lick Run watershed is predominantly undeveloped. Howesville is the only town that has area within its boundaries and is technically considered an unincorporated community and a coal town. Development and population growth have declined in Howesville since the surrounding coal mines stopped producing coal and shut down. There was once a post office in Howesville that operated from 1837 to 1950 (USGS 2014a), though a census for the town has never been taken. Development of Howesville, especially within the Lick Run watershed, is not expected to increase in the near future.

Other than Howesville, a few developed roads go through the Lick Run watershed. WV Route 26, also known as Kingston Road, weaves its way through the western headwater area of the watershed and WV Route 72 cuts through the mouth of it. County Route 59, also known as Old Tunnelton-Kingwood Road, follows the southwestern boarder of the watershed, and County Route 26/26 cuts through the center of the watershed. Small undeveloped roads, Ken Snyder, Lloyd Wilson, and Jerreries are offshoots from County Route 26/26 and can also be seen within the watershed in Figure 17, below. 


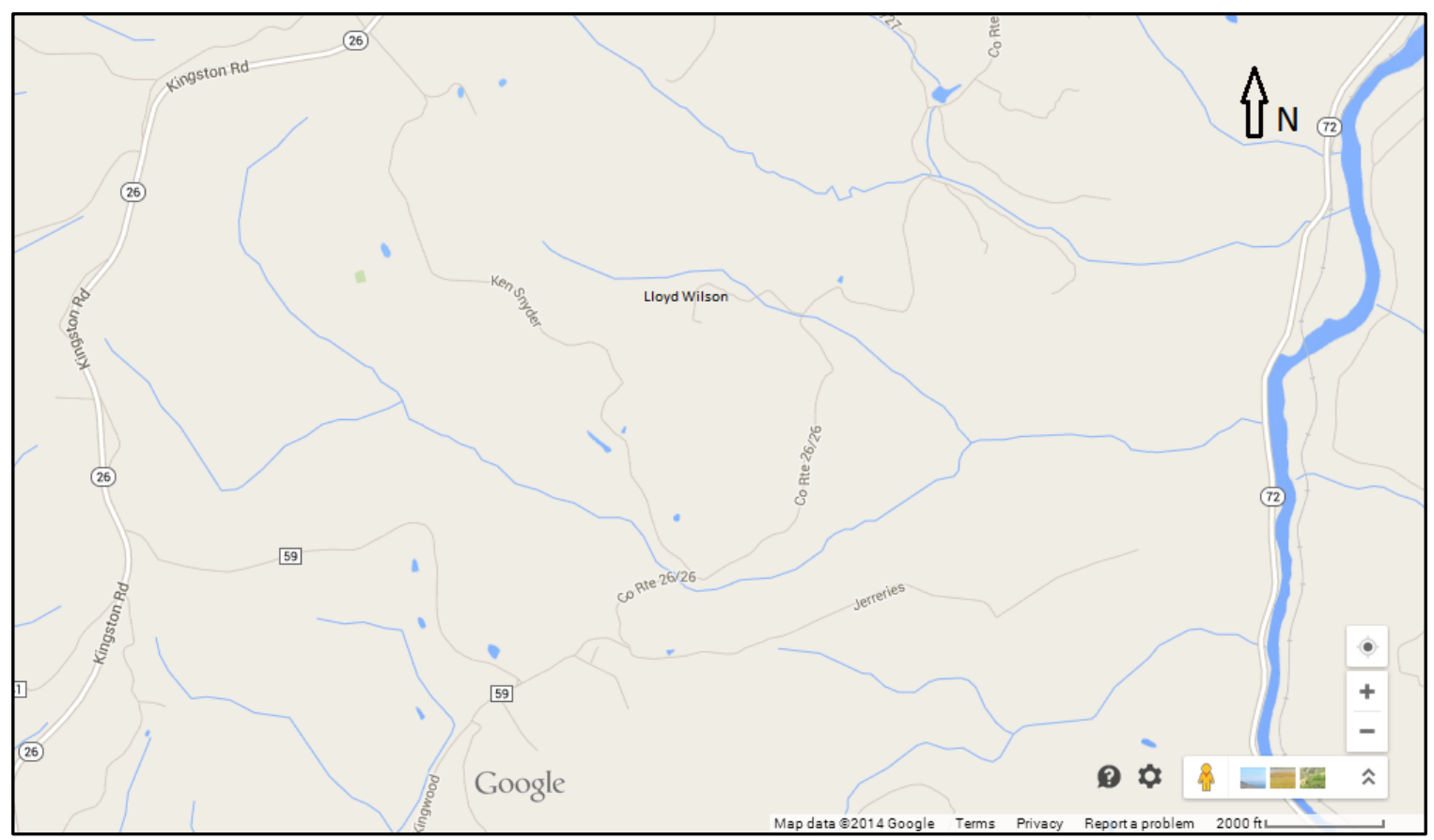

Figure 17: Street map by Google Maps. Scale bar $=2000$ feet.

The following figure shows an impervious surfaces map of the Lick Run watershed. The darker the area on the map, the more pervious and undeveloped, thus more natural the surface land is. The lighter the area on the map, the more impervious thus developed the surface land is. WV Route 26 and Howesville create the most developed area in the Lick Run watershed (Figure 18), this can land be seen on the western edge, above Lick Run's headwaters. The gray lines that twist through the watershed represent roadway, and the sporadic, bright white spots are small residential and farm buildings. Data for Figure 18 were made available by the WVGISTC (WVGISTC 2014). 


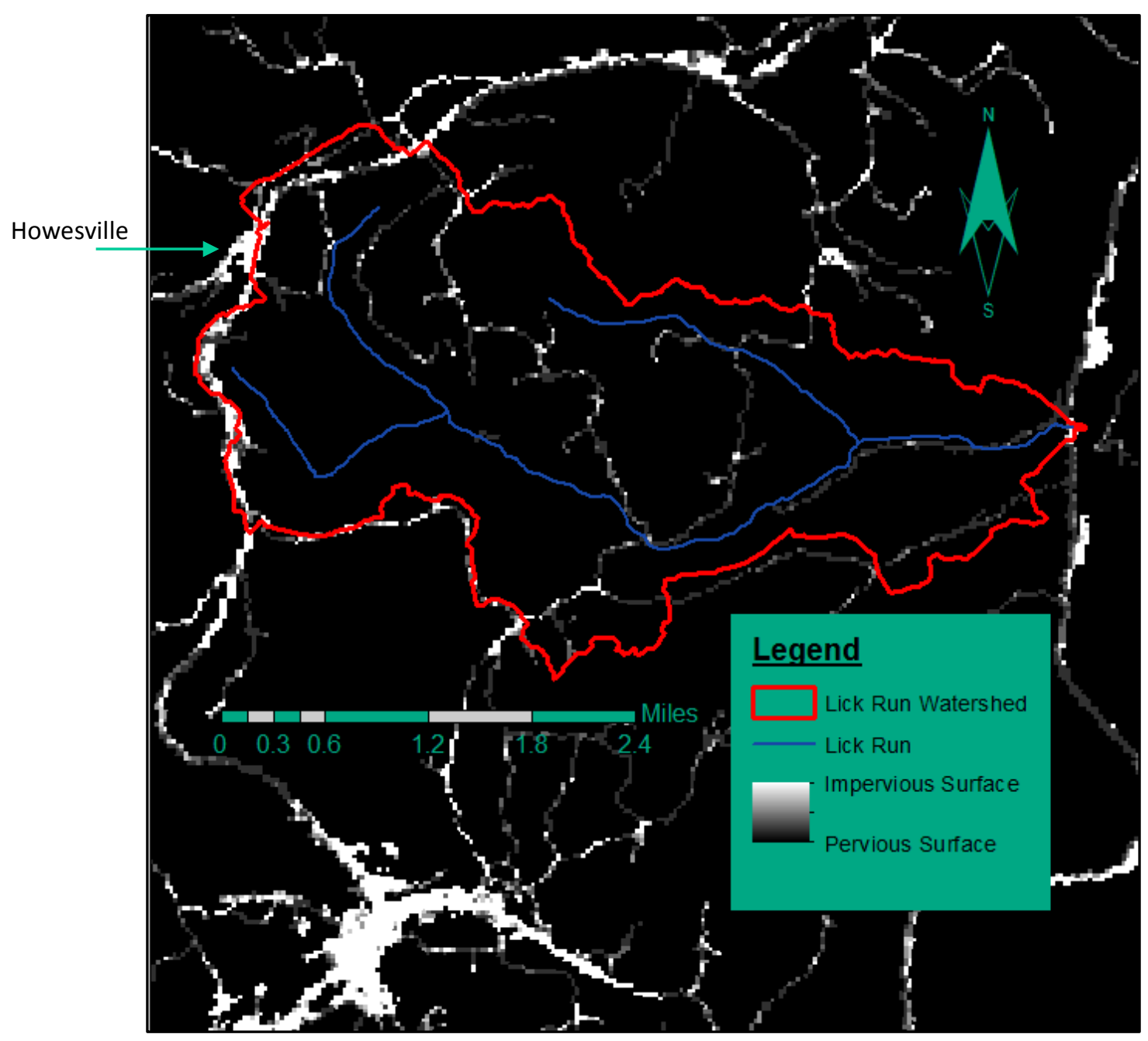

Figure 18: Impervious Surfaces Map.

\subsubsection{Political Boundaries}

All of Lick Run's watershed is located within Preston County, WV. The majority of its land area is privately owned and contains no Federal or State land, and no Indian reservations. In the undeveloped parts of the watershed, most land is owned by holding companies who then lease the land to groups of citizens, clubs, or organizations for recreational purposes like hunting. For example, Allegheny Forestlands, LLC owns much of the forested land in the southeastern, undeveloped parts of the watershed. Also, there are no sites within the watershed that are listed on the National Register of Historic Places (Landmark Geospatial 2014).

One plot of land that is of interest is a parcel that is owned by the Friends of the Cheat. This area is of special concern because it is located at the Bottom Fork, where the most considerable amount of acid mine drainage originates. This site is the location where the largest passive treatment system is suggested to be installed. Though the entire system would not fit within its 
boundaries, much of it will, and this would cut down on costs and ability to find land for large scale treatment purposes. A map depicting this plot of land is provided in Figure 19 below (Landmark Geospatial 2014).

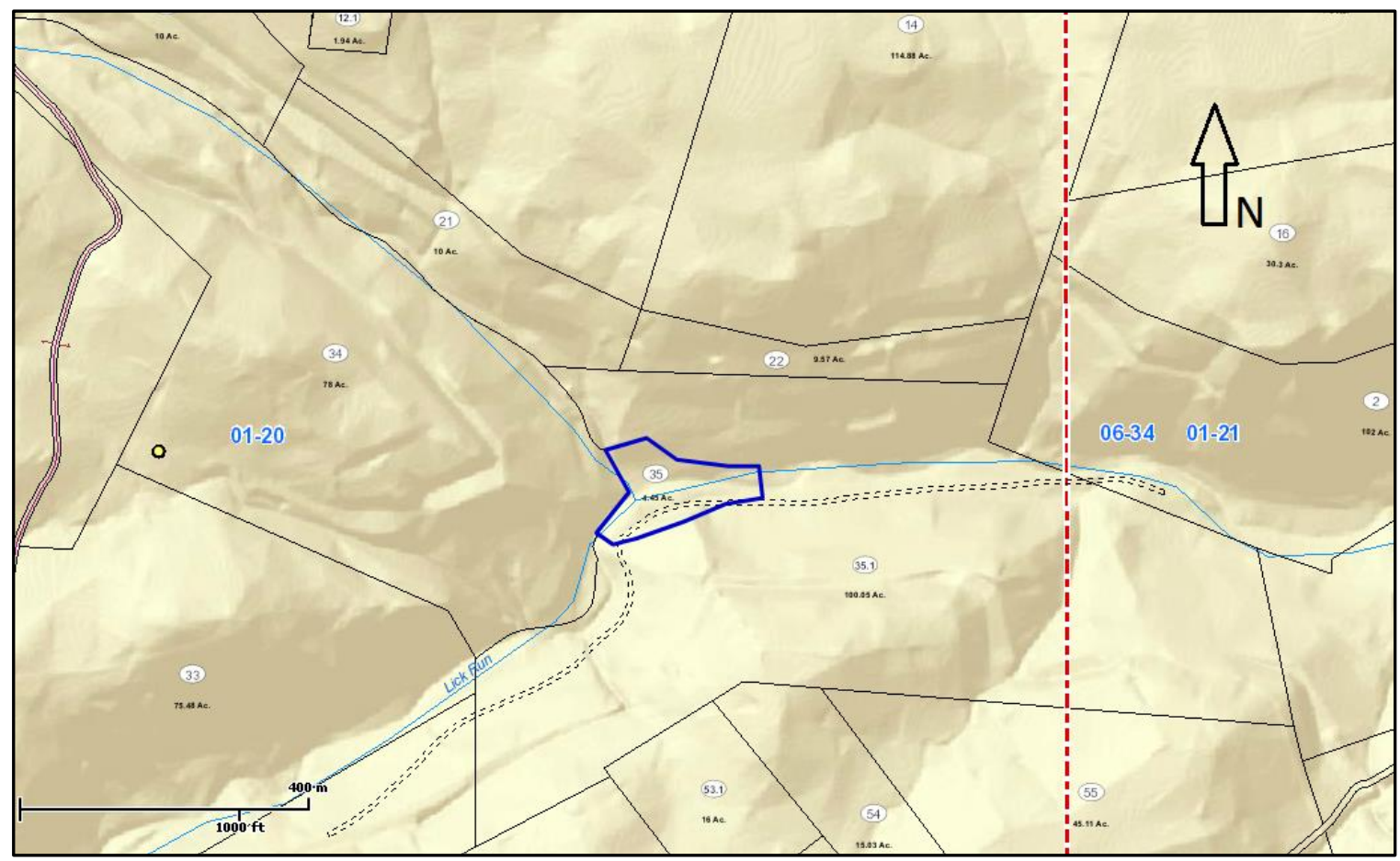

Figure 19: Land owned by Friends of the Cheat within the Lick Run watershed. Location information: District 01, Map 20, PID 35. Full scale bar $=400 \mathrm{~m}$. 


\section{Results}

\subsection{AMD Pollutant Source Assessment}

\subsubsection{Mining Ramifications}

Most coal mining in the Lick Run watershed was done in the Upper Freeport coal seam; the rest in the Bakerstown coal seam. The majority of underground coal mining was done in the 1920's and the vast majority of surface coal mining was done during WWII, in the 1940s (Patton et al. 1959). Apart from a small area on the southwestern border of the watershed, which was excavated in 1983, all of the mining performed in the Lick Run watershed was completed before the 1977 Surface Mining Control and Reclamation Act (SMCRA) (WVDEP TAGIS 2014). The Office of Surface Mining Reclamation and Enforcement (OSMRE) maintains what is known as the Abandoned Mine Lands Inventory System (AMLIS), and has identified nine problem areas within the Lick Run watershed (Figure 20). Of these nine Problem Areas Descriptions (PADs), three have been reclaimed, one has been partially reclaimed, and five have not been funded, nor reclaimed yet. Water conveyance measures such as wet seals and limestone channels have been installed at the reclaimed problem areas, but no water quality remediation measures have been implemented (OSMRE 2014). WVWRI completed water quality monitoring of a select group of these PADs based on reclamation status, accessibility, and time and funding limitations. 


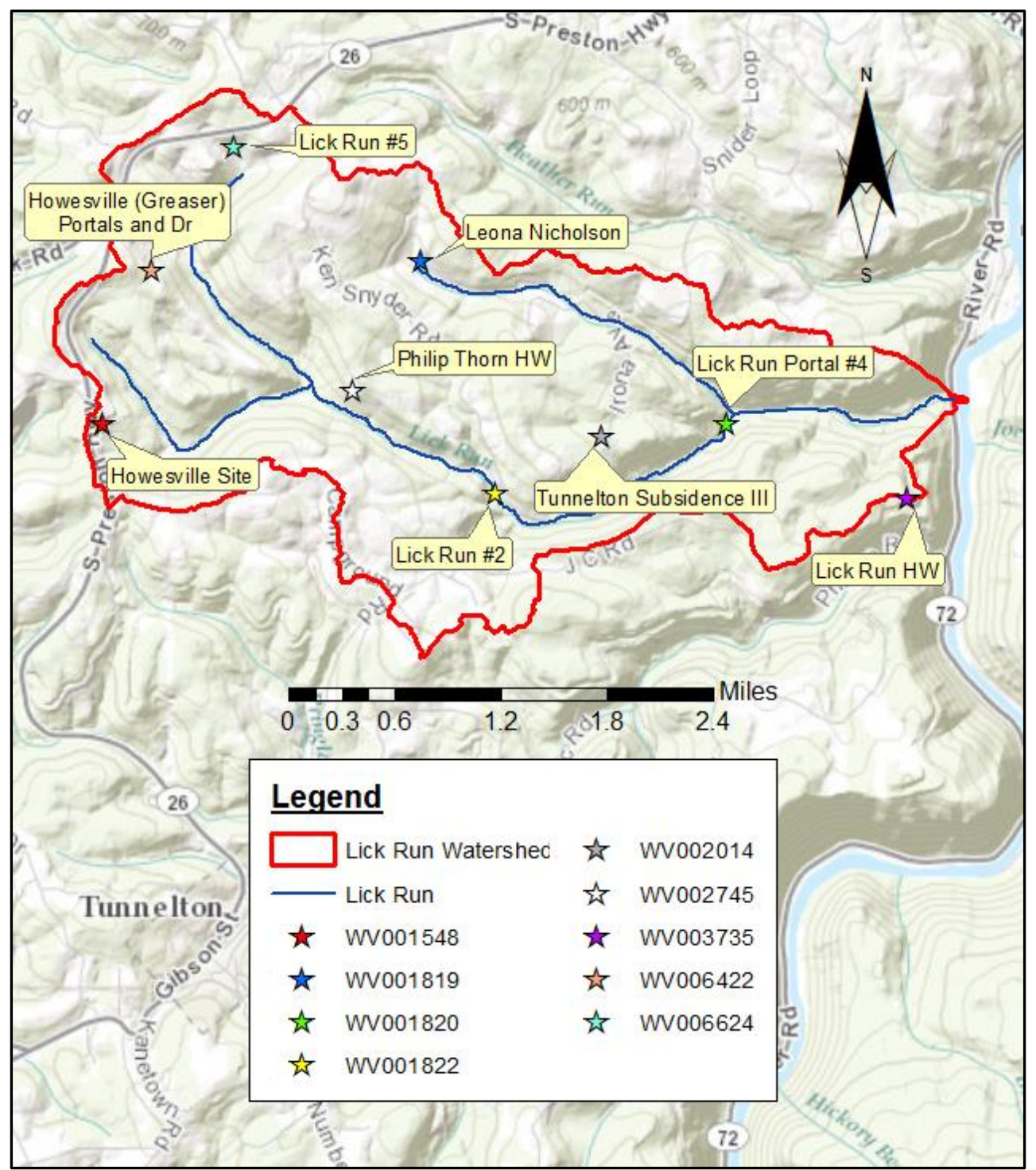

Figure 20: Map of Problem Area Descriptions (PADs) within the Lick Run watershed. This figure corresponds with Table 4.

The following (Table 4), shows a list of Lick Run's watershed PAD's and directly corresponds with Figure 20. This table shows the name of each AMLIS site along with their respective AMLIS number, location, problem descriptions, priority, and funding/ completion status. Of these sites, the Howesville (Greaser) Portals and Dr, Howesville Site, Lick Run Portal \#4, and Lick Run \#2 were monitored and sampled. Besides Lick Run \#2, these sites were chosen because they have water quality issues and open portals that have not been addressed nor remediated, making them the most problematic areas in the watershed. Lick Run \#2 was chosen to be sampled due to its ease of access and to be used in comparison to the other sites that have not passed all of their AMLIS priorities.

The other mine sites impacts on the watershed can be seen through the various in-stream sample sites that were monitored during the sampling stage of this project. The Bottom Fork Middle 
sample site is almost entirely, if not entirely, impaired by the Leona Nicholson AMLIS site. Trib 1 DS reflects the impacts presented by both Howesville sites, Lick Run \#5, Philip Thorn HW, Lick Run \#2, and the impacts contributed from Trib 1. Bottom Fork US shows water quality in the mainstem, before the Lick Run \#4 portals and the Middle Start Tributary converge. Lastly, the Discharge sites show the full amount of impairment from all PADs from Lick Run into the Cheat River, as well as water quality before and after Lick Run's contribution.

Table 4: List of Problem Area Descriptions (PADs) within the Lick Run watershed. All funded problem areas have been completed (reclaimed). This table corresponds with Figure 20.

\begin{tabular}{|c|c|c|c|c|c|c|}
\hline Site & AMLIS \# & Lattitude & Longitude & Description & Priority & Funded \\
\hline \multirow{8}{*}{ Howesville Site } & \multirow{8}{*}{ WV001548 } & \multirow{8}{*}{$39^{\circ} 25^{\prime} 31^{\prime \prime} \mathrm{N}$} & \multirow{8}{*}{$79^{\circ} 45^{\prime} 26^{\prime \prime} \mathrm{W}$} & Dangerous HWs & 1 & yes \\
\hline & & & & Portals & 2 & yes \\
\hline & & & & Hazardous Equipment \& Facilities (Pre-SMCRA) & 2 & yes \\
\hline & & & & Polluted Water: Agricultural \& Industrial & 2 & no \\
\hline & & & & Industrial/Residential Waste & 2 & yes \\
\hline & & & & Dangerous Impoundments & 2 & yes \\
\hline & & & & Dangerous HWs & 2 & no \\
\hline & & & & High Wall (HW) (Pre-SMCRA) & 3 & no \\
\hline Leona Nicholson & WV001819 & $39^{\circ} 26^{\prime} 08^{\prime \prime} \mathrm{N}$ & $79^{\circ} 43^{\prime} 52^{\prime \prime} \mathrm{W}$ & Dangerous Piles \& Embankments & 1 & yes \\
\hline \multirow{6}{*}{ Lick Run Portal \#4 } & \multirow{6}{*}{ WV001820 } & \multirow{6}{*}{$39^{\circ} 25^{\prime} 31^{\prime \prime} \mathrm{N}$} & \multirow{6}{*}{$79^{\circ} 42^{\prime} 22^{\prime \prime W}$} & Dangerous Impoundments & 2 & no \\
\hline & & & & Portals & 2 & no \\
\hline & & & & Dangerous HWs & 2 & no \\
\hline & & & & Equipment Facility & 3 & no \\
\hline & & & & Water Problems & 3 & no \\
\hline & & & & Gobs & 3 & no \\
\hline \multirow{5}{*}{ Lick Run \#2 } & \multirow{5}{*}{ WV001822 } & \multirow{5}{*}{$39^{\circ} 25^{\prime} 15^{\prime \prime} \mathrm{N}$} & \multirow{5}{*}{$79^{\circ} 43^{\prime} 30^{\prime \prime} \mathrm{W}$} & Subsidence (Pre-SMCRA) & 2 & yes \\
\hline & & & & Portals & 2 & yes \\
\hline & & & & Hazardous Equipment \& Facilities (Pre-SMCRA) & 2 & yes \\
\hline & & & & Dangerous Impoundments & 2 & yes \\
\hline & & & & Gobs & 3 & yes \\
\hline Tunnelton Subsidence III & WV002014 & $39^{\circ} 25^{\prime} 28^{\prime \prime} \mathrm{N}$ & $79^{\circ} 42^{\prime} 59^{\prime \prime} \mathrm{W}$ & Subsidence (Pre-SMCRA) & 2 & no \\
\hline \multirow{9}{*}{ Philip Thorn HW } & \multirow{9}{*}{ WV002745 } & \multirow{9}{*}{$39^{\circ} 25^{\prime} 23^{\prime \prime} \mathrm{N}$} & \multirow{9}{*}{$79^{\circ} 43^{\prime} 55^{\prime \prime} \mathrm{W}$} & Vertical Openings & 2 & yes \\
\hline & & & & Polluted Water: Agricultural \& Industrial & 2 & yes \\
\hline & & & & Industrial/Residential Waste & 2 & yes \\
\hline & & & & Hazardous Equipment \& Facilities (Pre-SMCRA) & 2 & yes \\
\hline & & & & Dangerous Piles \& Embankments & 2 & yes \\
\hline & & & & Dangerous Impoundments & 2 & yes \\
\hline & & & & Dangerous HWs & 2 & yes \\
\hline & & & & Portals & 2 & yes \\
\hline & & & & High Wall (HW) (Pre-SMCRA) & 3 & yes \\
\hline \multirow{4}{*}{ Lick Run HW } & \multirow{4}{*}{ WV003735 } & \multirow{4}{*}{$39^{\circ} 25^{\prime} 14^{\prime \prime} \mathrm{N}$} & \multirow{4}{*}{$79^{\circ} 41^{\prime} 29^{\prime \prime} \mathrm{W}$} & Portals & 2 & no \\
\hline & & & & Dangerous HWs & 2 & no \\
\hline & & & & Dangerous Piles \& Embankments & 2 & no \\
\hline & & & & Hazardous Equipment \& Facilities (Pre-SMCRA) & 2 & no \\
\hline \multirow{2}{*}{$\begin{array}{c}\text { Howesville (Greaser) } \\
\text { Portals and Dr }\end{array}$} & \multirow{2}{*}{ WV006422 } & \multirow{2}{*}{$39^{\circ} 26^{\prime} 06^{\prime \prime} \mathrm{N}$} & \multirow{2}{*}{$79^{\circ} 45^{\prime} 11^{\prime \prime} \mathrm{W}$} & Dangerous Impoundments & 2 & no \\
\hline & & & & Water Problems & 3 & no \\
\hline \multirow{3}{*}{ Lick Run \#5 } & \multirow{3}{*}{ WV006624 } & & & Dangerous HWs & 1 & no \\
\hline & & $39^{\circ} 26^{\prime} 34^{\prime \prime} \mathrm{N}$ & $79^{\circ} 44^{\prime} 47^{\prime \prime} \mathrm{W}$ & Dangerous Impoundments & 2 & no \\
\hline & & & & Gobs & 3 & no \\
\hline
\end{tabular}


Further analysis of the AMLIS sites was performed to create the following map. Figure 21 shows abandoned mine land territory and mining permit boundaries within the Lick Run watershed. This map specifically shows a single surface mining permit boundary that is no longer open. This permit was for the Angela Mining Co. Inc., was issued on December 17, 1982, and expired on December 17, 1992 without any work being done (WVDEP TAGIS 2014). These data were made available by the WV GIS Technical Center and the WVDEP; it uses Abandoned Mine Lands and Reclamation (AMLR) source materials (WVGISTC 2014).

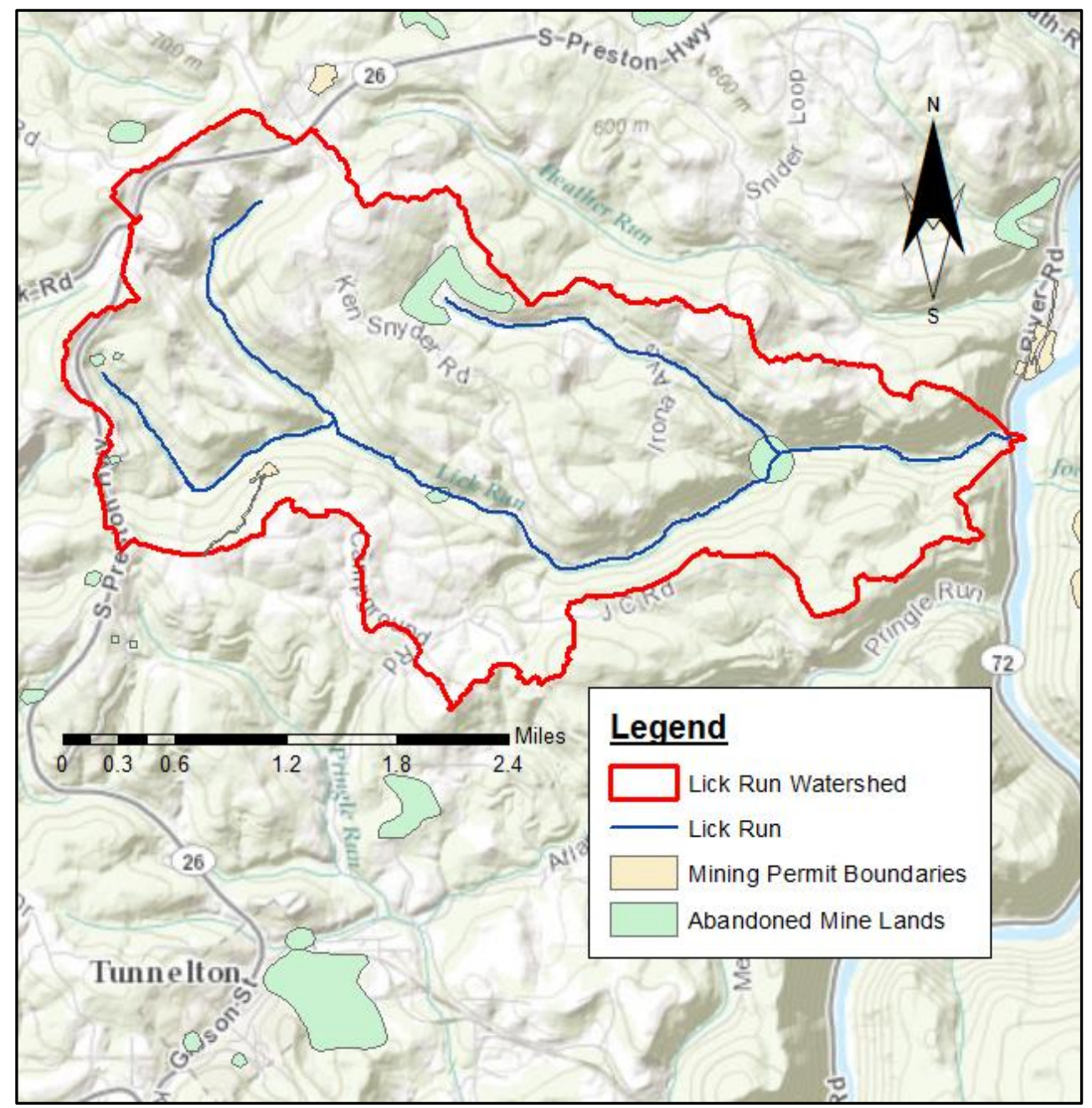

Figure 21: Abandoned mine land territories and mining permit boundaries in the Lick Run watershed.

Figure 21 shows that the largest abandoned mine land territories in the Lick Run watershed are at the Leona Nicholson site and the Lick Run \#4 site. The Leona Nicholson portal(s) were not tested by the WVWRI during their sampling period because it only has a single priority 1 problem area, and it has been fully funded and reclaimed, according to AMLIS. The Lick Run \#4 site, however, is the leading contributor to AMD in the watershed and has three priority 2 and 3 problem areas that are not funded nor reclaimed. Two other small abandoned mine areas are shown in Figure 21; one is located above the headwaters to the Southern Start Tributary, the other, roughly midway through Lick Run's mainstem. 
The following tables show average water quality results of the four mine sites that were tested for use in this project, as well as the in-stream sites. Table 5 shows average mine site water quality data and Table 6 shows average in-stream water quality data. Four samples were planned to be taken for each site, during the sampling period however, some sites were removed and added based on accessibility, when they were found, and/ or when they were realized to be in the incorrect location. Details on how many times each site was tested is provided in Section 3.1.

Table 5: Average mine-site water quality data $(n=4)$. Plus signs $\left({ }^{+}\right)$denotes three sample values. Values in parenthesis represent ranges in measured flowrates.

\begin{tabular}{|c|c|c|c|c|c|c|c|c|c|c|c|}
\hline \multirow[b]{2}{*}{ Mine Sites } & \multirow{2}{*}{$\frac{\text { Field }}{\text { Flow }}$} & \multicolumn{10}{|c|}{$\underline{\text { Lab }}$} \\
\hline & & $\mathrm{pH}^{*}$ & $\begin{array}{c}\text { Alk } \\
\mathrm{mg} / \mathrm{L}\end{array}$ & $\begin{array}{c}\text { Acd } \\
\mathrm{mg} / \mathrm{L}\end{array}$ & $\begin{array}{c}\mathrm{SO} 4 \\
\mathrm{mg} / \mathrm{L}\end{array}$ & $\begin{array}{l}\text { Cond. } \\
\text { uS/cm }\end{array}$ & $\begin{array}{c}\mathrm{Al} \\
\mathrm{mg} / \mathrm{L}\end{array}$ & $\begin{array}{c}\mathrm{Ca} \\
\mathrm{mg} / \mathrm{L}\end{array}$ & $\begin{array}{c}\mathrm{Fe} \\
\mathrm{mg} / \mathrm{L}\end{array}$ & $\begin{array}{c}\mathrm{Mg} \\
\mathrm{mg} / \mathrm{L}\end{array}$ & $\begin{array}{c}\mathrm{Mn} \\
\mathrm{mg} / \mathrm{L}\end{array}$ \\
\hline Lick Run \#2 & $\begin{array}{c}6.6 \\
(4.7-8.5) \\
\end{array}$ & 3.05 & 0.5 & 486.07 & 536.4 & 1562 & 27.69 & 37.46 & 43.34 & 12.84 & 0.86 \\
\hline Lick Run \#4 P1 & $\begin{array}{c}501.0 \\
(211.0-772.4) \\
\end{array}$ & 3.18 & 0.5 & 521.68 & 700.8 & 1602 & 34.61 & 46.89 & 53.26 & 20.21 & 0.83 \\
\hline Lick Run \#4 P2 & $\begin{array}{c}685.4 \\
(228.9-1425.9)\end{array}$ & 2.88 & 0.5 & 1201.45 & 1516.5 & 2703 & 48.36 & 71.19 & 114.93 & 29.44 & 1.25 \\
\hline Lick Run \#4 P3 ${ }^{+}$ & $\begin{array}{c}757.2 \\
(67.3-1432.4) \\
\end{array}$ & 3.50 & 0.5 & 324.54 & 539.3 & 1020 & 23.86 & 47.99 & 38.56 & 15.68 & 0.92 \\
\hline Howesville Site & $\begin{array}{c}74.8 \\
(4.5-203.1) \\
\end{array}$ & 4.79 & 7.41 & 39.69 & 92.5 & 336 & 2.34 & 25.25 & 0.57 & 4.86 & 0.73 \\
\hline $\begin{array}{l}\text { Howesville } \\
\text { Greaser }\end{array}$ & $\begin{array}{c}49.0 \\
(9.0-95.3)\end{array}$ & 3.00 & 0.5 & 604.33 & 615.5 & 1790 & 22.42 & 39.38 & 87.77 & 8.58 & 1.17 \\
\hline
\end{tabular}

Table 6: Average in-stream water quality data $(n=4)$. Plus signs $\left({ }^{+}\right)$denotes three sample values, asterisks $(*)$ denote single sample values. Values in parenthesis represent ranges in measured flowrates.

\begin{tabular}{|c|c|c|c|c|c|c|c|c|c|c|c|}
\hline \multirow{2}{*}{$\begin{array}{l}\text { In-Stream } \\
\text { Sites }\end{array}$} & \multirow{2}{*}{$\frac{\text { Field }}{\text { Flow }}$} & \multicolumn{10}{|c|}{ Lab } \\
\hline & & $\mathrm{pH}^{*}$ & $\begin{array}{c}\text { Alk } \\
\mathrm{mg} / \mathrm{L} \\
\end{array}$ & $\begin{array}{c}\text { Acd } \\
\mathrm{mg} / \mathrm{L}\end{array}$ & $\begin{array}{c}\mathrm{SO} 4 \\
\mathrm{mg} / \mathrm{L} \\
\end{array}$ & $\begin{array}{l}\text { Cond. } \\
\mathrm{uS} / \mathrm{cm}\end{array}$ & $\begin{array}{c}\mathrm{Al} \\
\mathrm{mg} / \mathrm{L}\end{array}$ & $\begin{array}{c}\mathrm{Ca} \\
\mathrm{mg} / \mathrm{L} \\
\end{array}$ & $\begin{array}{c}\mathrm{Fe} \\
\mathrm{mg} / \mathrm{L} \\
\end{array}$ & $\begin{array}{c}\mathrm{Mg} \\
\mathrm{mg} / \mathrm{L}\end{array}$ & $\begin{array}{c}\mathrm{Mn} \\
\mathrm{mg} / \mathrm{L} \\
\end{array}$ \\
\hline $\begin{array}{l}\text { Discharge } \\
\text { Mouth }\end{array}$ & $\begin{array}{c}2680.4 \\
(951.5-5197.7) \\
\end{array}$ & 3.31 & 0.5 & 357.85 & 515.1 & 1219 & 22.60 & 44.47 & 30.45 & 15.77 & 0.80 \\
\hline Discharge US & $\mathrm{N} / \mathrm{A}$ & 5.67 & 25.94 & 6.41 & 17.5 & 79 & 0.17 & 8.81 & 0.15 & 1.77 & 0.04 \\
\hline Discharge DS & $\mathrm{N} / \mathrm{A}$ & 4.24 & 1.91 & 73.40 & 110.3 & 327 & 4.71 & 16.34 & 3.03 & 4.62 & 0.18 \\
\hline $\begin{array}{l}\text { Bottom Fork } \\
\text { Middle }^{+}\end{array}$ & $\begin{array}{c}294.0 \\
(178.2-515.4)\end{array}$ & 3.47 & 0.5 & 263.49 & 346.3 & 998 & 17.46 & 35.37 & 19.20 & 9.03 & 1.00 \\
\hline $\begin{array}{l}\text { Bottom Fork } \\
\text { US* }\end{array}$ & N/A & 3.47 & 0.5 & 95.90 & 137.0 & 461 & 4.78 & 17.21 & 1.68 & 4.48 & 0.46 \\
\hline Trib 1 Mouth* & 185.1 & 3.56 & 0.5 & 193.48 & 231.5 & 703 & 13.10 & 39.96 & 3.53 & 10.47 & 0.45 \\
\hline Trib 1 US* & 770.9 & 3.55 & 0.5 & 113.81 & 140.0 & 526 & 6.48 & 17.98 & 3.95 & 5.13 & 0.49 \\
\hline Trib 1 DS & $\begin{array}{c}1417.5 \\
(264.8-2698.4)\end{array}$ & 3.65 & 0.5 & 108.77 & 149.0 & 507 & 6.54 & 20.47 & 7.41 & 5.52 & 0.64 \\
\hline
\end{tabular}

According to the 2011 Cheat River TMDL, all of Lick Runs mainstem is impaired by $\mathrm{pH}$, metals, and biological impairments (Tetra Tech 2011). The Middle Start Tributary is also listed as impaired by the same parameters, except for biological. The Southern Start Tributary is not listed 
as impaired for anything, however, it is influenced by AMD from the Howesville Site mine/ problem area. Table 7, below, details Lick Run and its tributaries impaired stream lengths, pollutant type impairments, and the number of abandoned mines that affect them.

Table 7: Detailed analysis of Lick Runs impacted stream segments.

\begin{tabular}{|c|c|c|c|}
\hline Sample Point & Impaired Stream Miles & Pollutant Type & Pollutant Source \\
\hline \hline Lick Run Mainstem & 4.50 & $\mathrm{Fe}, \mathrm{Al}, \mathrm{Mn}, \mathrm{pH}, \mathrm{Bio}$ & 7 Abandoned Mines \\
\hline Middle Start Tributary & 1.63 & $\mathrm{Fe}, \mathrm{Al}, \mathrm{Mn}, \mathrm{pH}$ & 1 Abandoned Mines \\
\hline Southern Start Tributary & $0(1.32$ impacted $)$ & None & 1 Abandoned Mines \\
\hline
\end{tabular}

\subsubsection{Mine Site Descriptions}

\section{Lick Run \#2}

The Lick Run \#2 site is located midway through Lick Run's mainstem. It is listed as WV001822 by AMLIS and used to have four priority 2 problem areas and one priority 3 problem area, but all of these priorities have received funding and have been reclaimed (Table 4). Although the site has been reclaimed, acidic mine drainage still emanates from at least two portals that had wet seals installed in them. Currently, water flows from the two wet seals into limestone channels that direct the two sources to a convergence, and eventually into Lick Run's mainstem. Figure 22 shows a picture of the two stream paths junction. Average water quality data can be found in Table 5 and the full record of results can be found in Appendix A. 


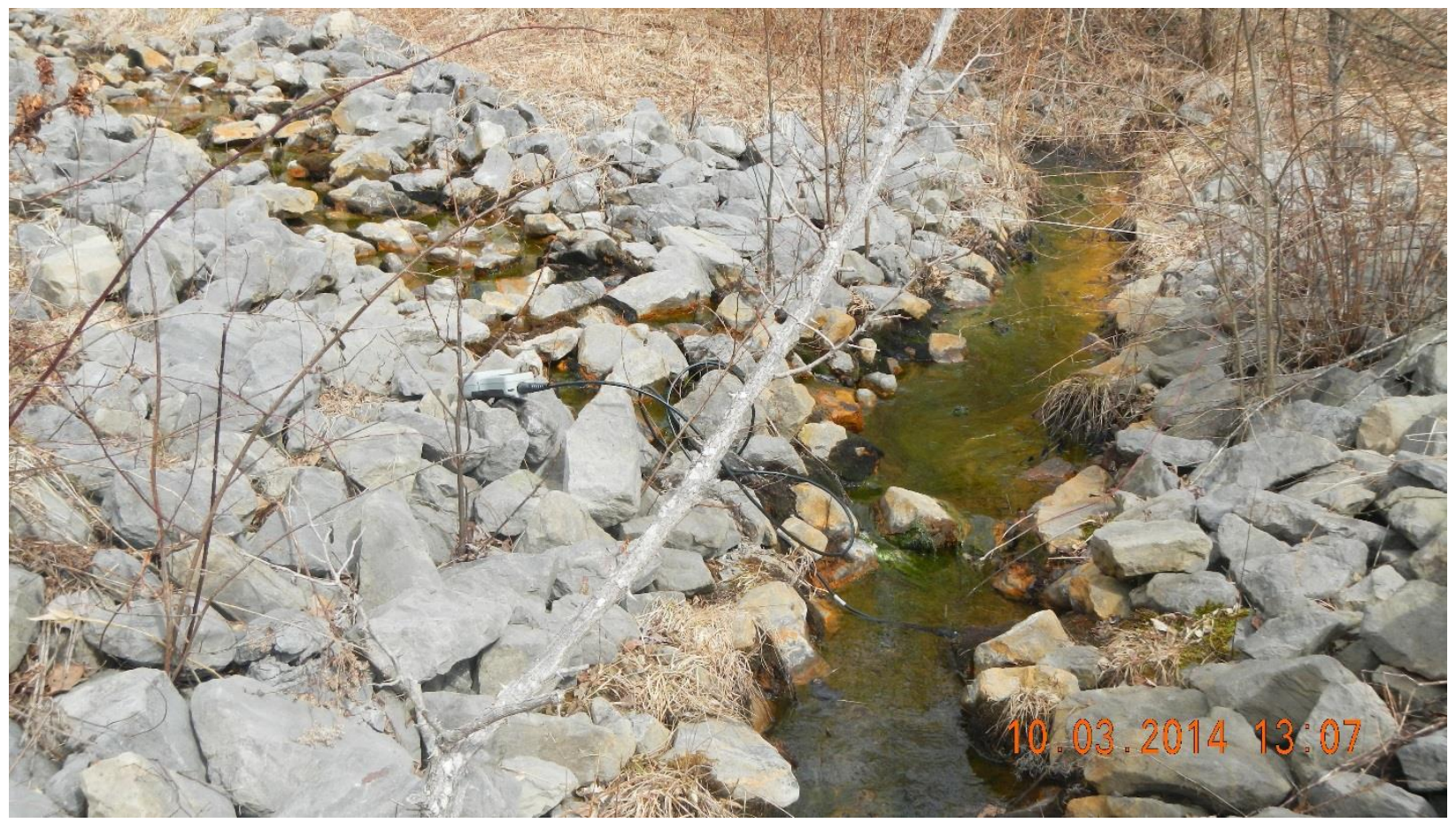

Figure 22: Lick Run \#2 limestone channels and stream path convergence before discharging into Lick Runs mainstem.

\section{Lick Run \#4}

The Lick Run \#4 site is located at the Bottom Fork of the Lick Run hydrological system. It is listed as WV001820 by AMLIS, has three priority 2 and three priority 3 problem areas, and none of these priorities have received funding (Table 4). Acidic mine drainage flows from three different portals within a small area that is all considered Lick Run Portal \#4 by AMLIS, or Lick Run \#4 Portals 1,2 , and 3 , by the WVWRI. Figure 23 shows a picture of P1's open portal, Figure 24 shows a picture of P2's open portal, and Figure 25 shows the rock outcrop that AMD seems to be emanating from, which is referred to as P3. All three of these portals are located within approximately 50 yards of each other, thus treatment of all three at the same time, through the same system, is the most practical and probable course of action. Average water quality data can be found in Table 5 and the full record of results can be found in Appendix A. It should be noted that portals 1 and 2 are tested directly, whereas portal 3 tests were taken at the mouth of the Middle Start Tributary, downstream of the P3 rock outcrop/ portal. 


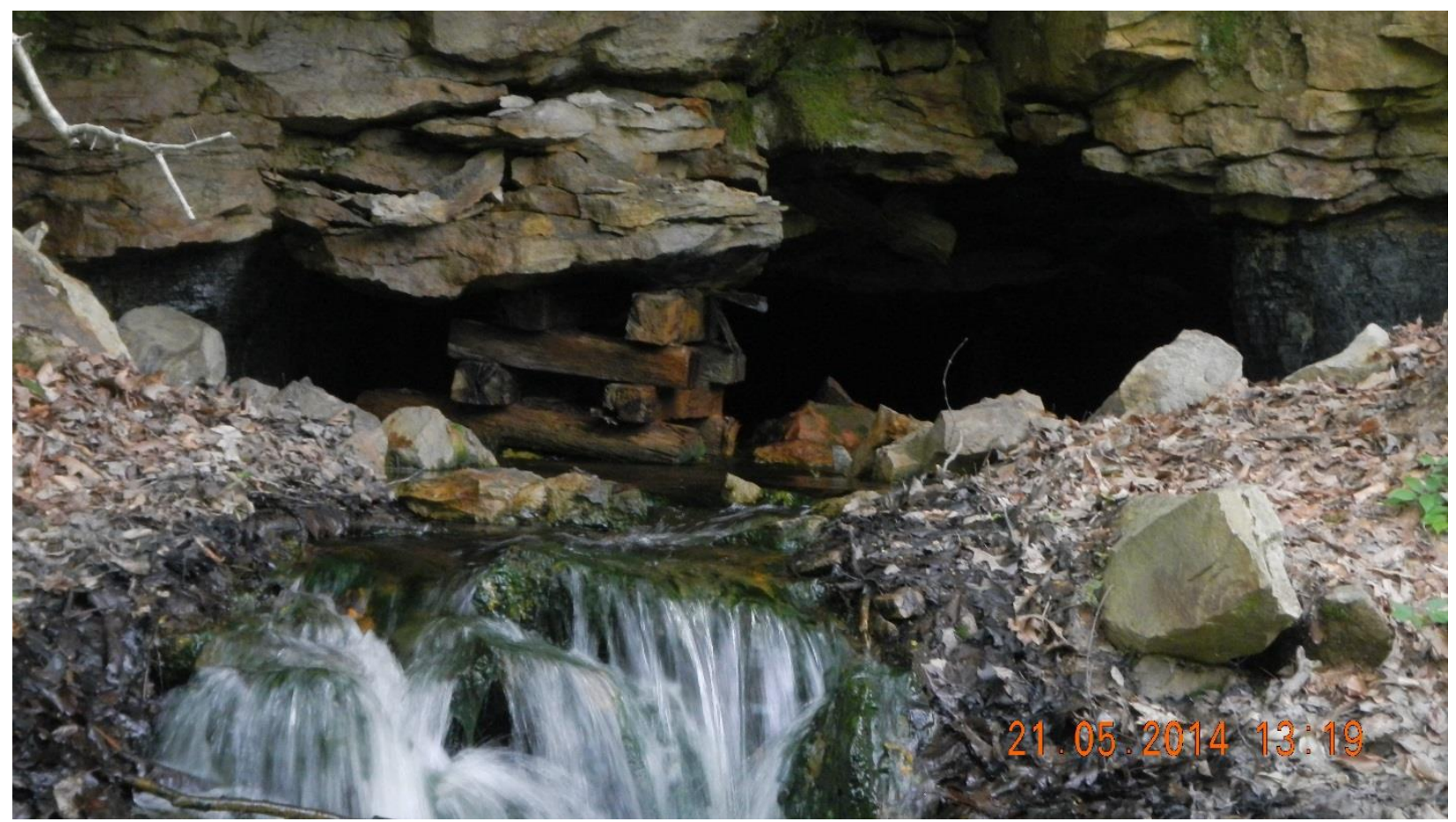

Figure 23: Lick Run \#4; P1s open portal.

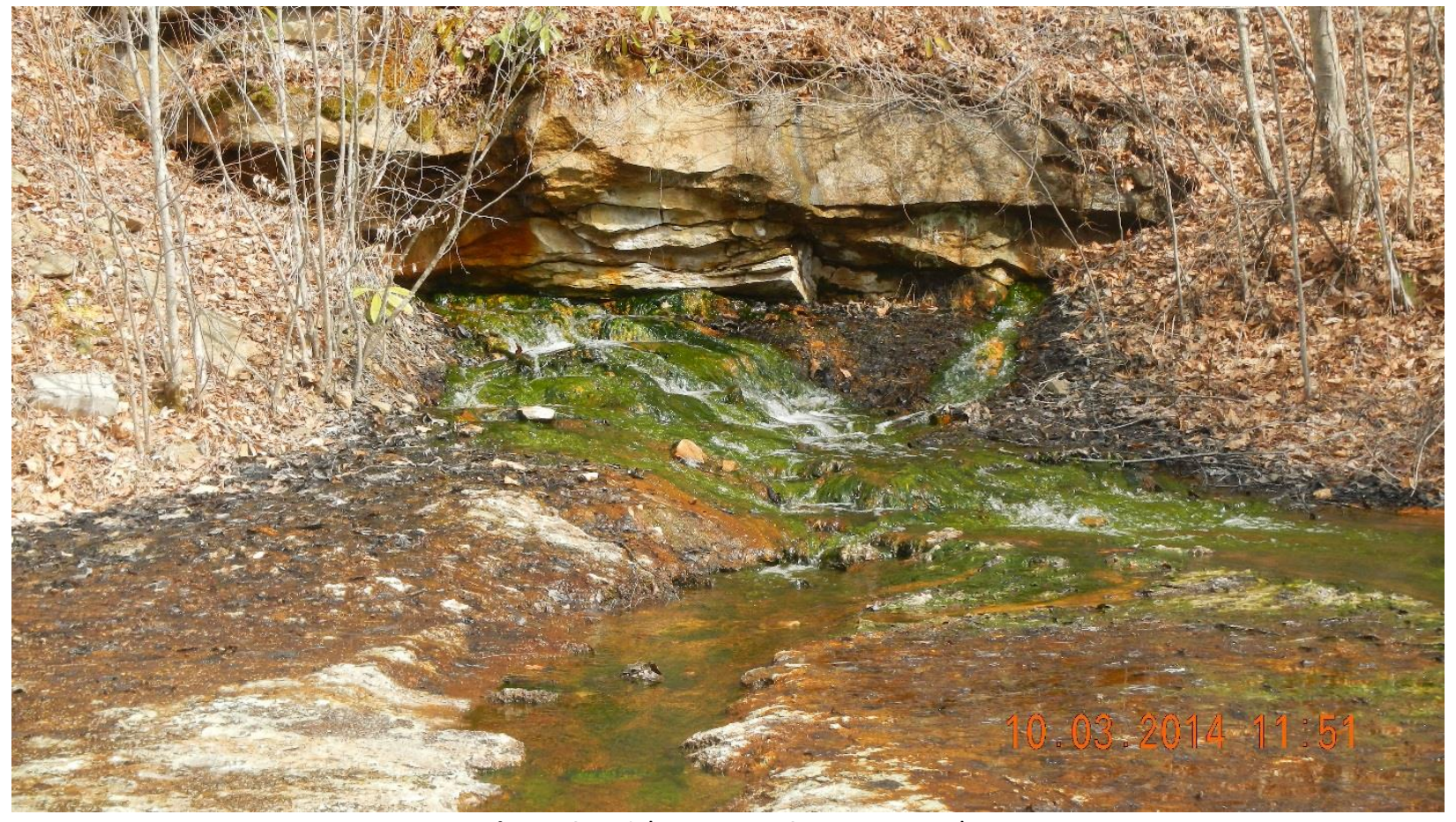

Figure 24: Lick Run \#4; P2s open portal. 


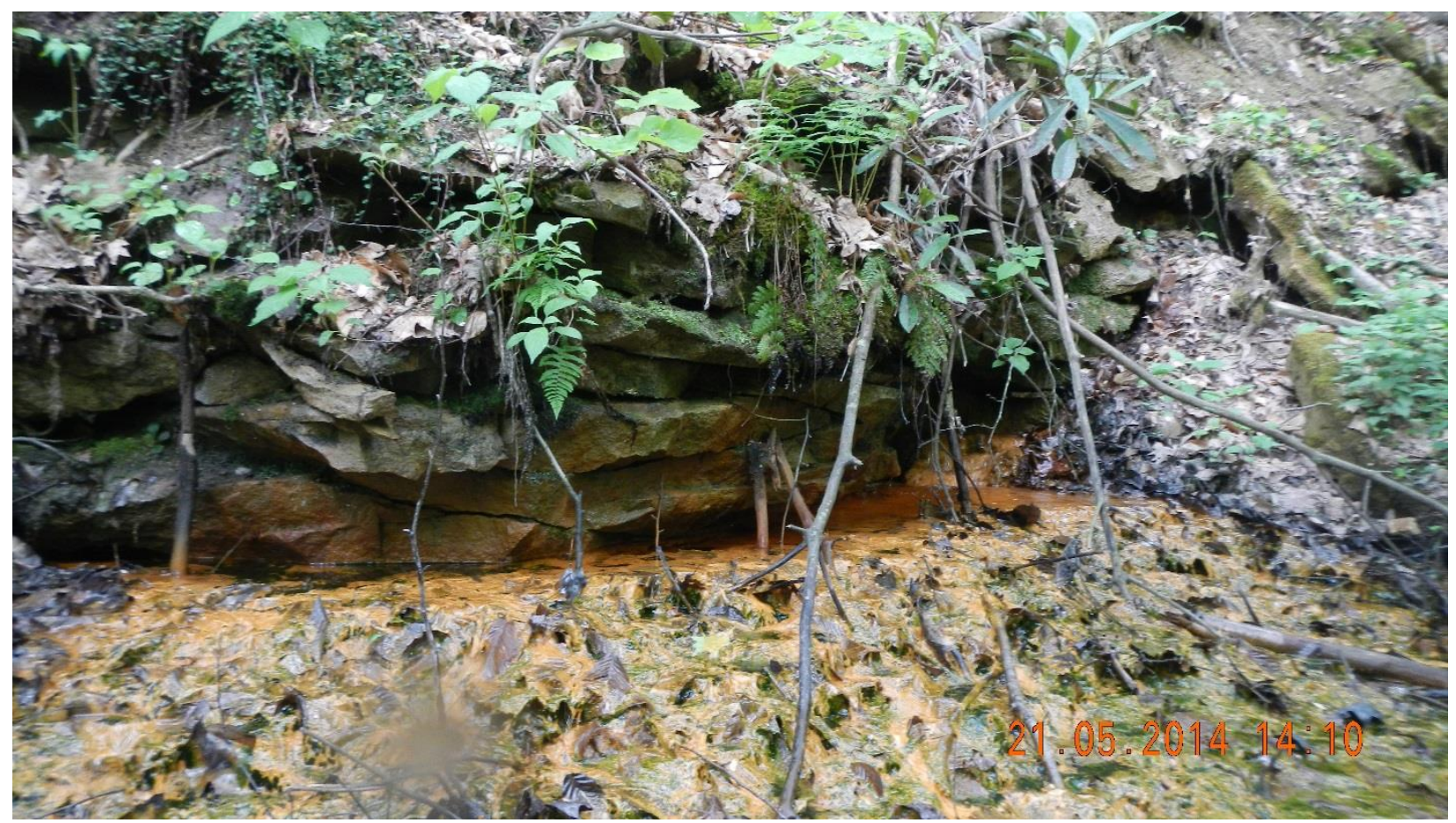

Figure 25: Lick Run \#4, P3s rock outcrop/ open portal.

\section{Howesville Site}

The Howesville Site is located in the headwaters of the Lick Run watershed, south of the Southern Start Tributary. It is listed as WV001548 by AMLIS, has one priority 1 problem area, six priority 2 problem areas, and one priority 3 problem area. Some of these problem areas have received funding and have been reclaimed, including the installation of a wet seal in the portal, but not all have been addressed (Table 4). This site was tested in order to be compared to the results that the DEP produced for the Cheat River TMDL, which states that the Southern Start Tributary is not affected by AMD. Results from WVWRI testing show that the Howesville site, on average, produces the cleanest water of all mines sites that were tested (Table 5), having the most ideal average $\mathrm{pH}$ rating (4.79) and significantly lower metal concentrations, conductivity, acidity, and sulfate levels. The only parameter that does not meet water quality standards (Section 3.3.2) is aluminum levels, which average to be $2.34 \mathrm{mg} / \mathrm{l}$. AMD originates from two main sources at the Howesville Site. Figures 26 and 27 show the two limestone channels that transports AMD from these sources to a convergence, which can be considered the beginning of the Southern Start Tributary. Figure 28 shows the convergence of the two AMD sources that mark the beginning of the Southern Start Tributary, testing was performed downstream of this. Average water quality data can be found in Table 5 and the full record of results can be found in Appendix $A$. 


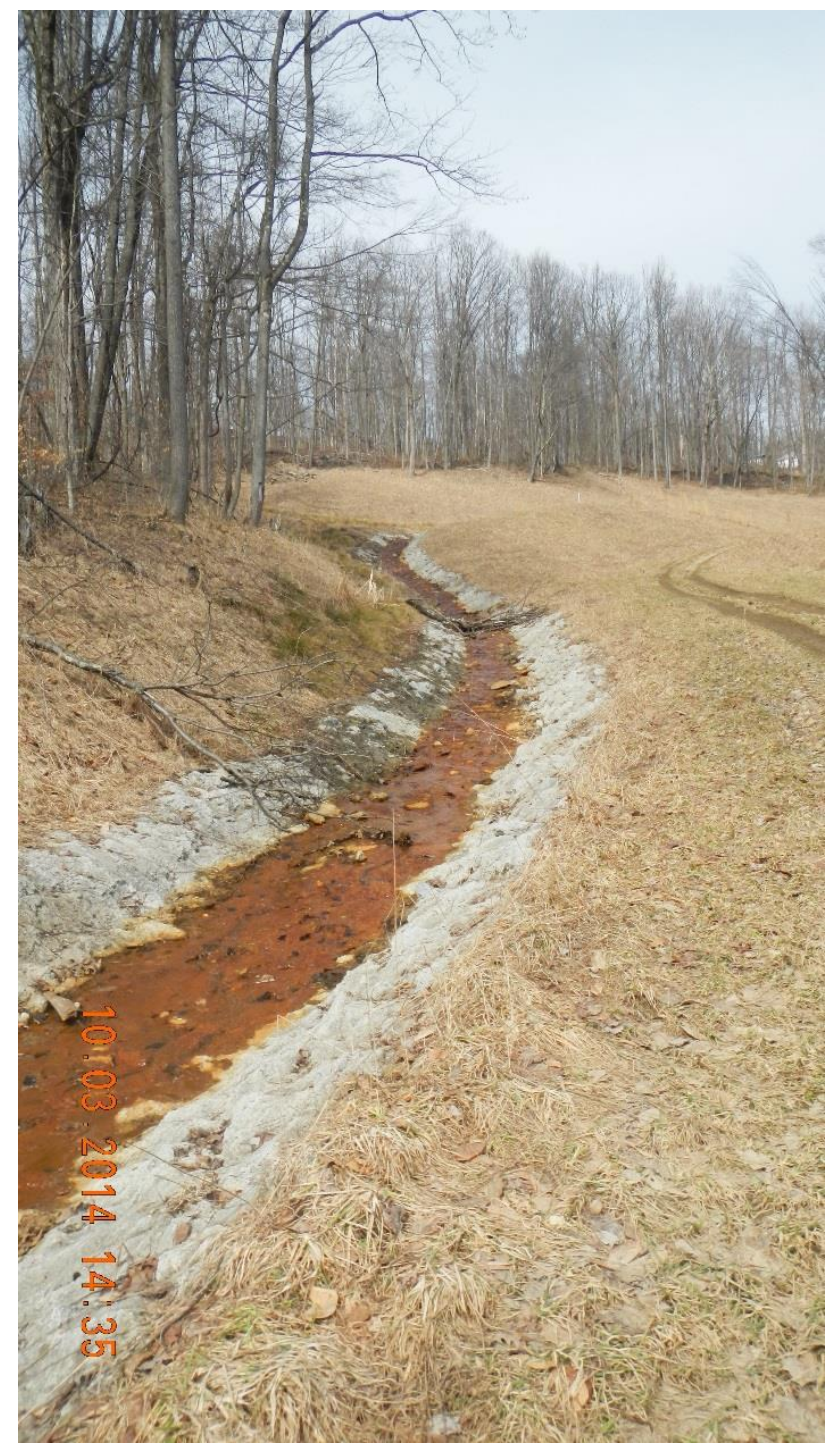

Figure 26: Howesville Site Limestone Channel 1

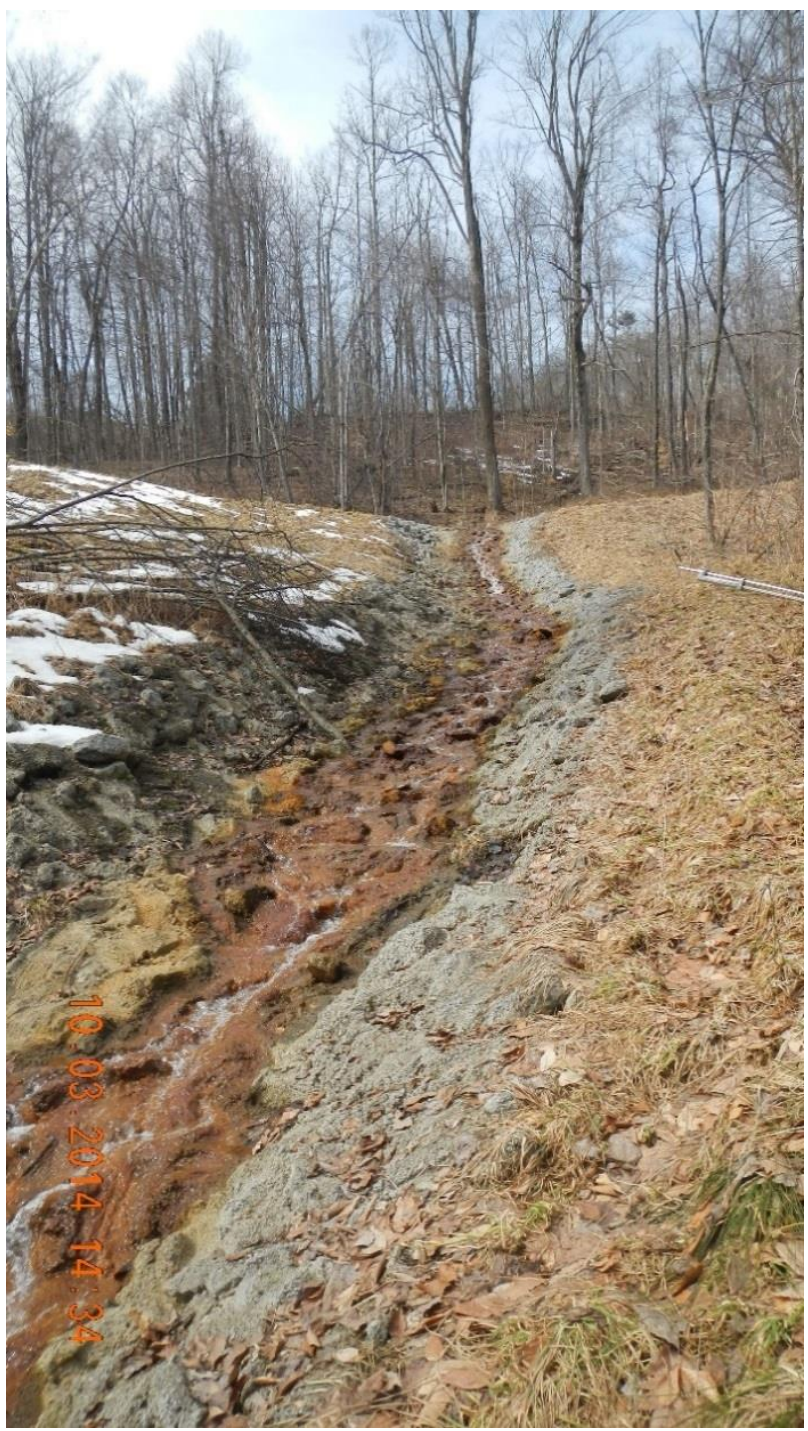

Figure 27: Howesville Site Limestone Channel 2 


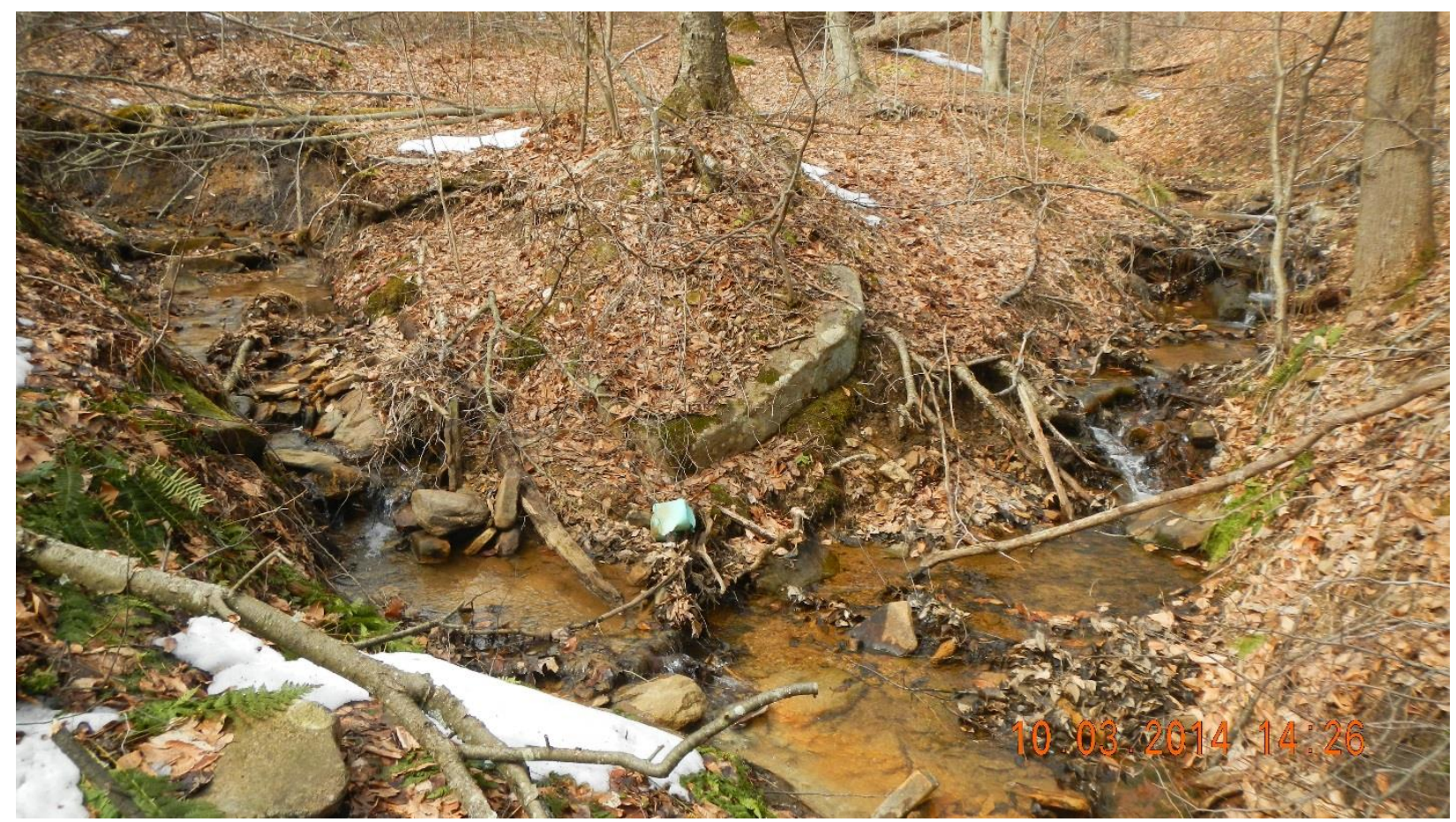

Figure 28: Howesville Sites two AMD source convergence.

\section{Howesville (Greaser)}

The Howesville (Greaser) site is located north of the Southern Start Tributary's headwaters, but flows into Lick Run's mainstem. It is called the Howesville (Greaser) Portals and Dr by AMLIS and is listed as WV006422. It has a priority 2 and a priority 3 problem area, and neither of them have been funded nor reclaimed (Table 4). This site has at least 4 different locations that produce AMD and are all directed to the same locations using limestone channels. These locations are believed to be small open portals or crevices that are seeping AMD at a very slow rate; put together, all four locations account for only a $49 \mathrm{gal} / \mathrm{min}$ flow. Figure 29 shows the first convergence; three of the AMD sources meet here to form a cross with their output, which then flows down the hill into the valley that is shown. Figure 30 depicts the second convergence; this is where the first convergences output meets with the fourth AMD source. All testing for this site was performed downstream of the second convergence. Average water quality data can be found in Table 5 and the full record of results can be found in Appendix A. 


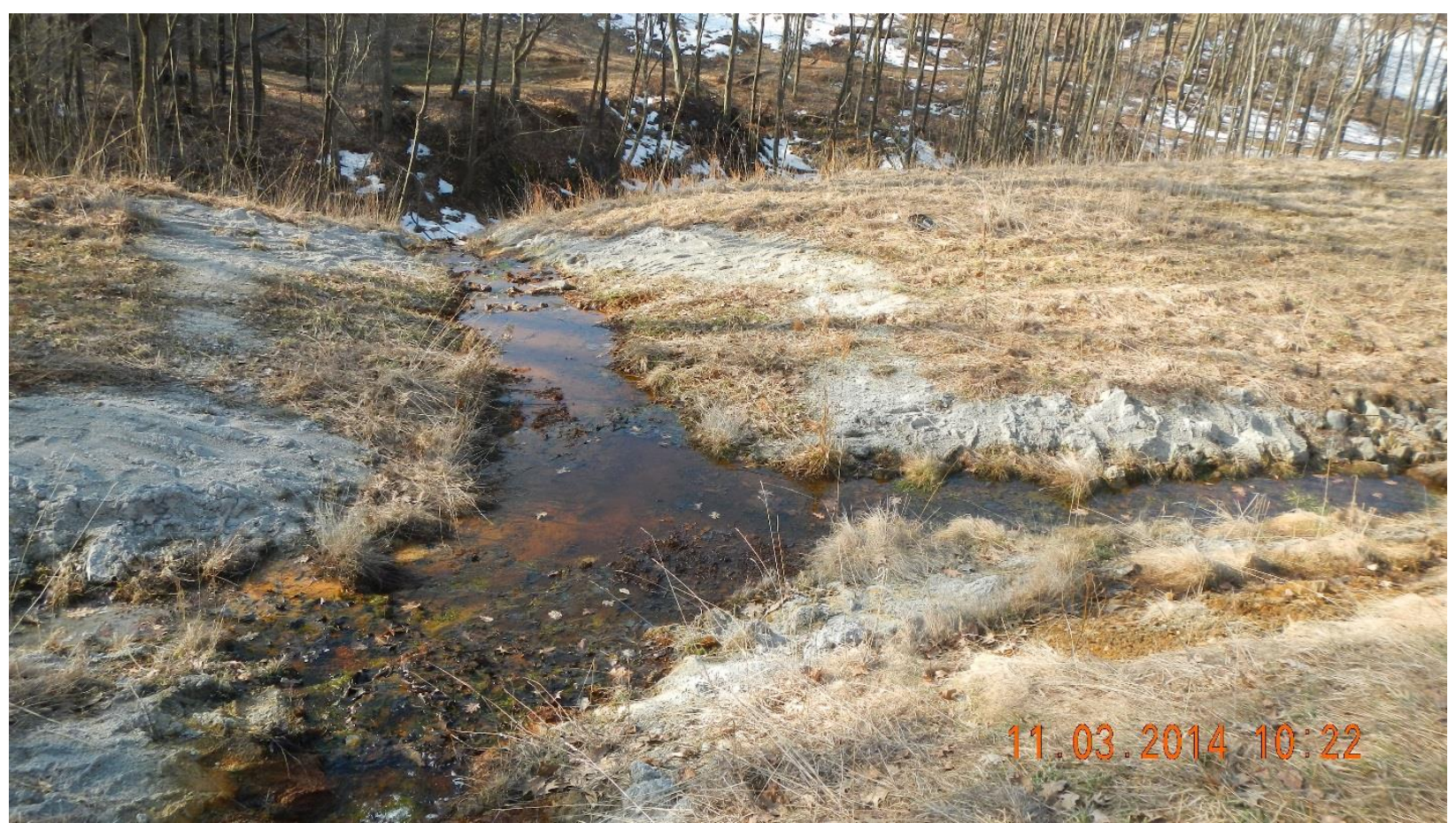

Figure 29: Howesville Greaser first convergence, looking downstream; three AMD sources merge here and then flow into the valley to another convergence (Figure 30).

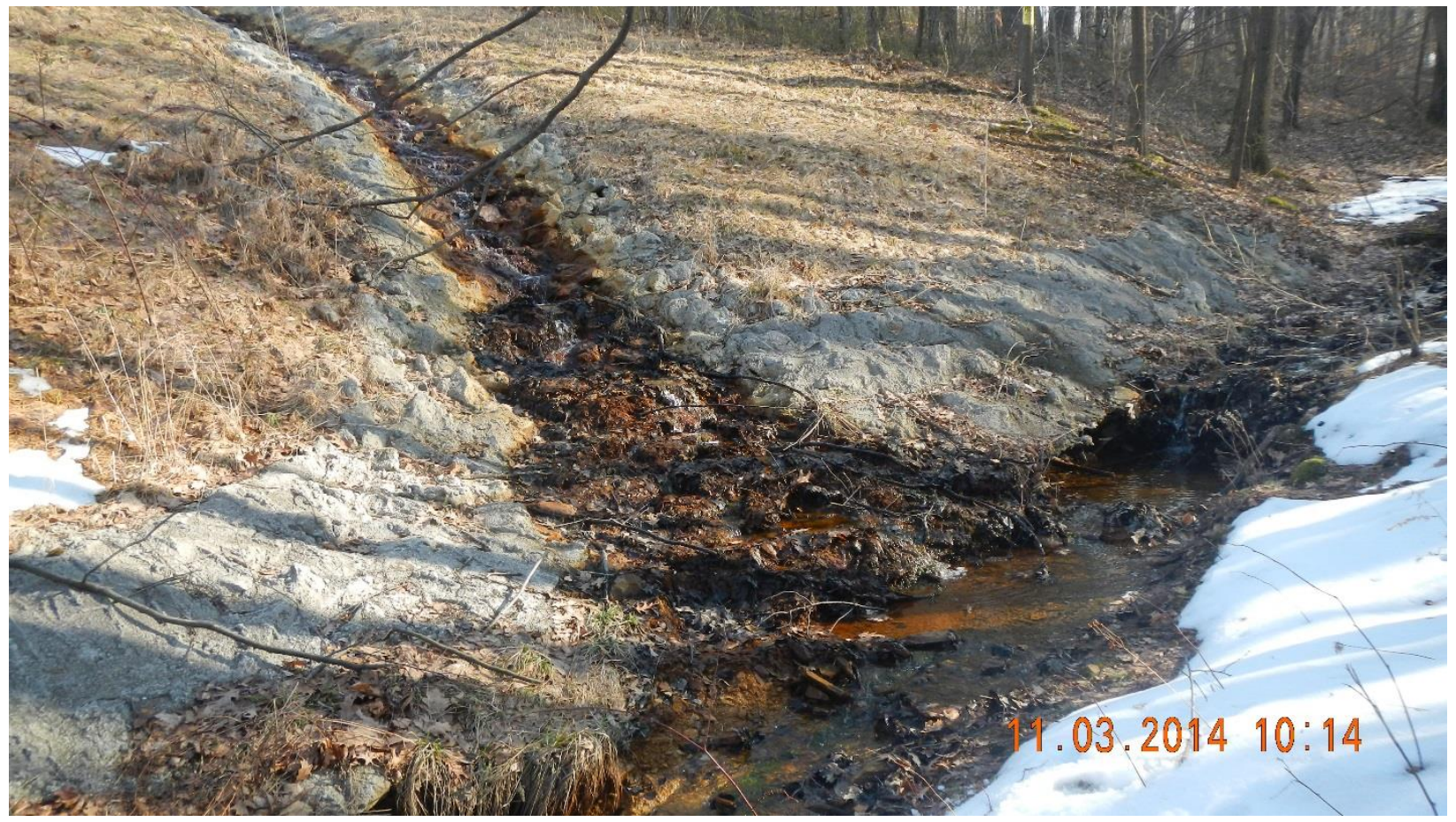

Figure 30: Howesville Greaser second convergence, looking upstream; the first convergence is located up the hill and the other channel comes from the fourth AMD source. 


\subsection{Water Quality Data Analysis}

\subsubsection{Metal Concentrations and pH Compared to Water Quality Standards}

The following charts compare $\mathrm{pH}$ levels and metal concentrations for mine sites and in-stream sites respectively. Each mine site graph compares all of the mine site sample results with each other, as well as providing the baseline for Water Quality Standards (WQS). The in-stream site graphs compare Lick Run's discharge with sample points taken midway through the mainstem (the Trib 1 DS location), as well as midway through the Middle Start Tributary (the Bottom Fork Middle location). These graphs also provide baseline WQS for further assessment. Lastly, these figures depict the sampling period by showing how many samples were taken and when they were obtained for analysis by date. Figures 31 and 32 show pH analysis, Figures 33 and 34 show aluminum (Al) concentration analysis, Figures 35 and 36 show iron (Fe) analysis, and Figures 37 and 38 shows the manganese ( $\mathrm{Mn})$ analysis.

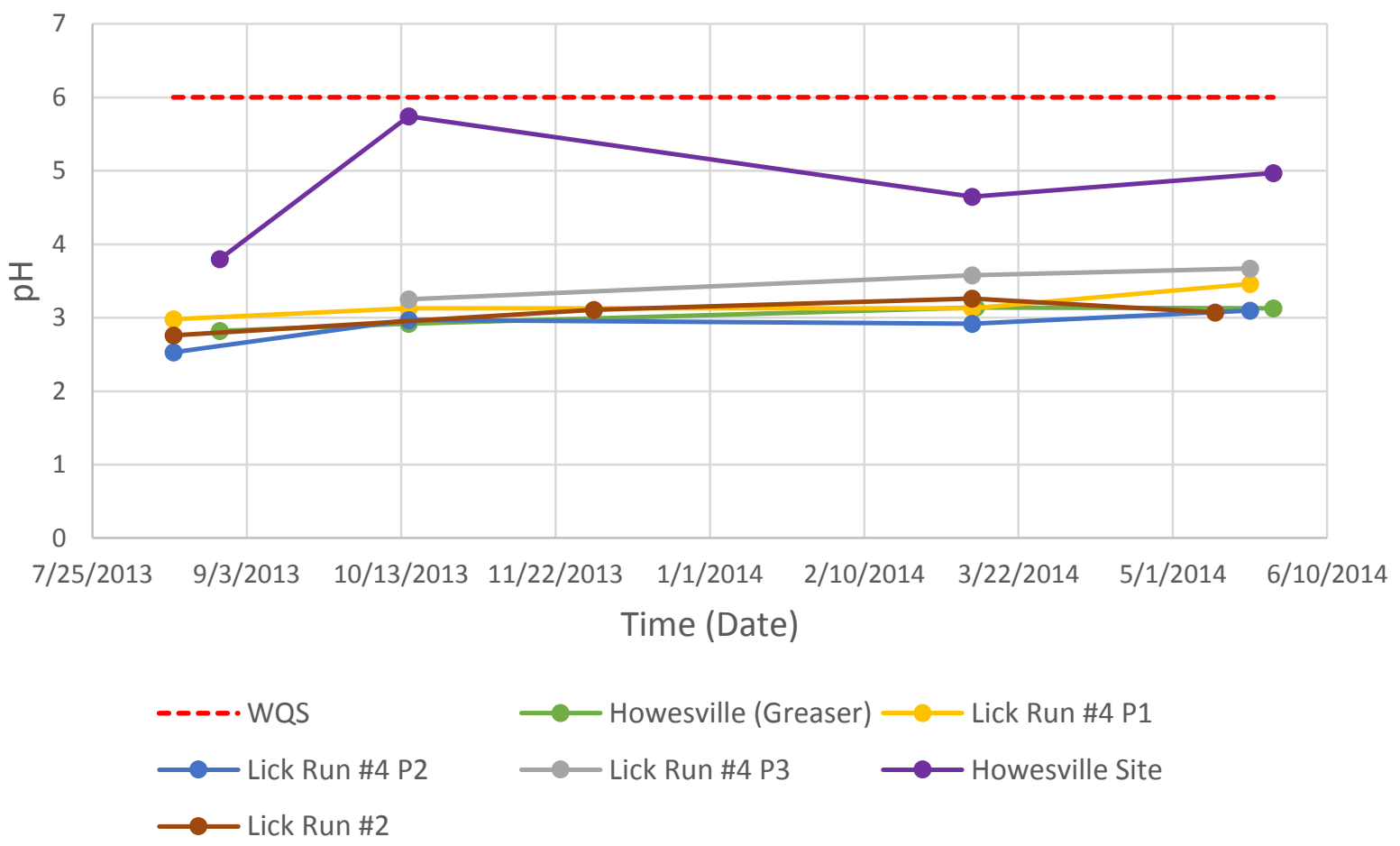

Figure 31: Mine Sites - Measured pH vs. WQS. 


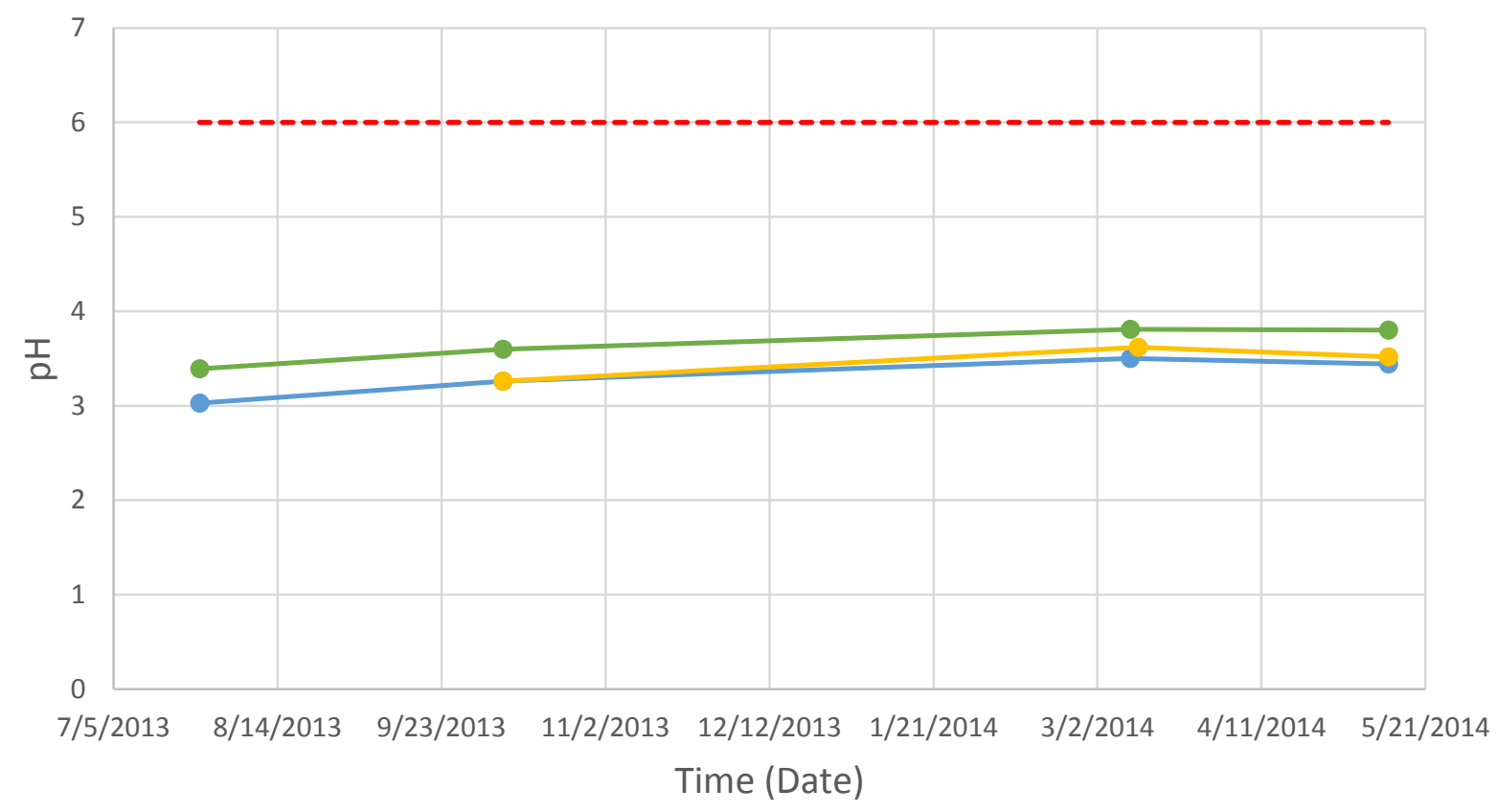

---.WQS $\longrightarrow$ Discharge Mouth $\longrightarrow$ Bottom Fork Middle $\longrightarrow$ Trib 1 DS

Figure 32: In-Stream Sites - Measured pH vs. WQS.

After analyzing Figures 31 and 32, it can be seen that all of the water quality samples taken were below WQS for $\mathrm{pH}$. All of the sites (mine and in-stream) followed a similar relationship apart from the Howesville Site, which had by far the best $\mathrm{pH}$ levels in the watershed, from what was sampled. During the second sample set, the Howesville Site $\mathrm{pH}$ was just under WQS at about 5.9; this was effectively the highest $\mathrm{pH}$ level recorded in the watershed during the entire sampling period among all sites. 


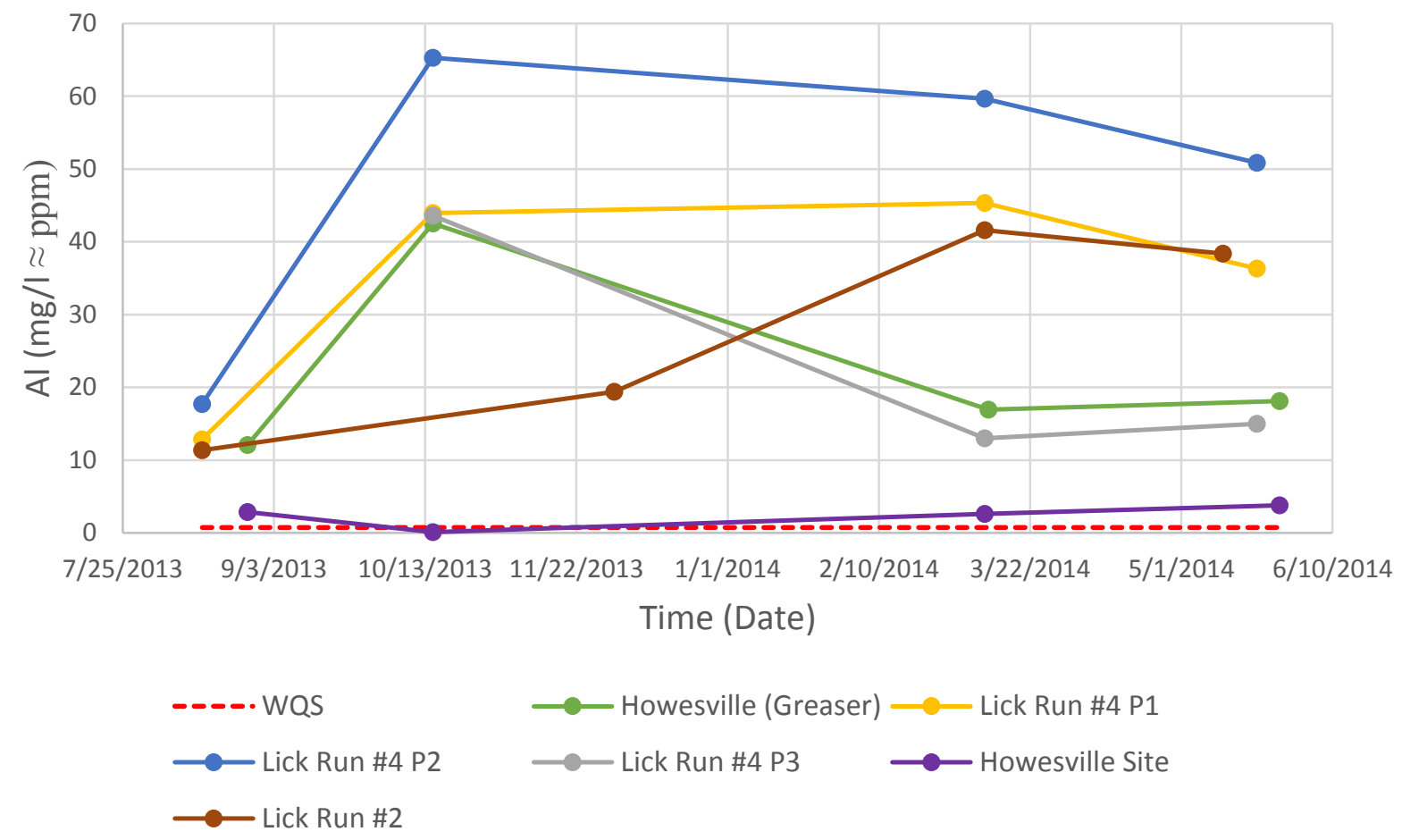

Figure 33: Mine Sites - Measured Al Concentration vs. WQS.

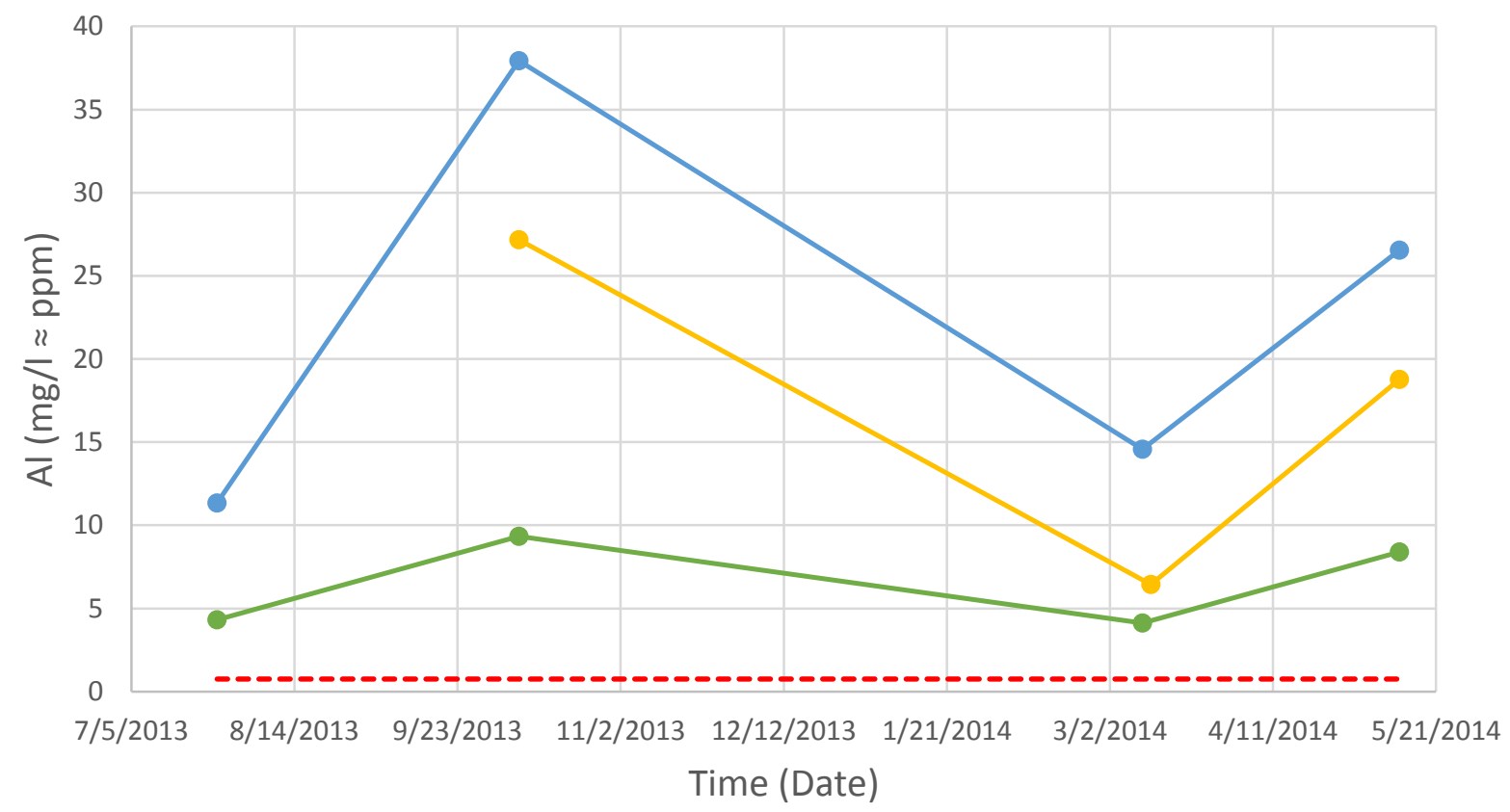

---..WQS $\longrightarrow$ Discharge Mouth $\longrightarrow$ Bottom Fork Middle $\longrightarrow$ Trib 1 DS

Figure 34: In-Stream Sites - Measured Al Concentrations vs. WQS. 


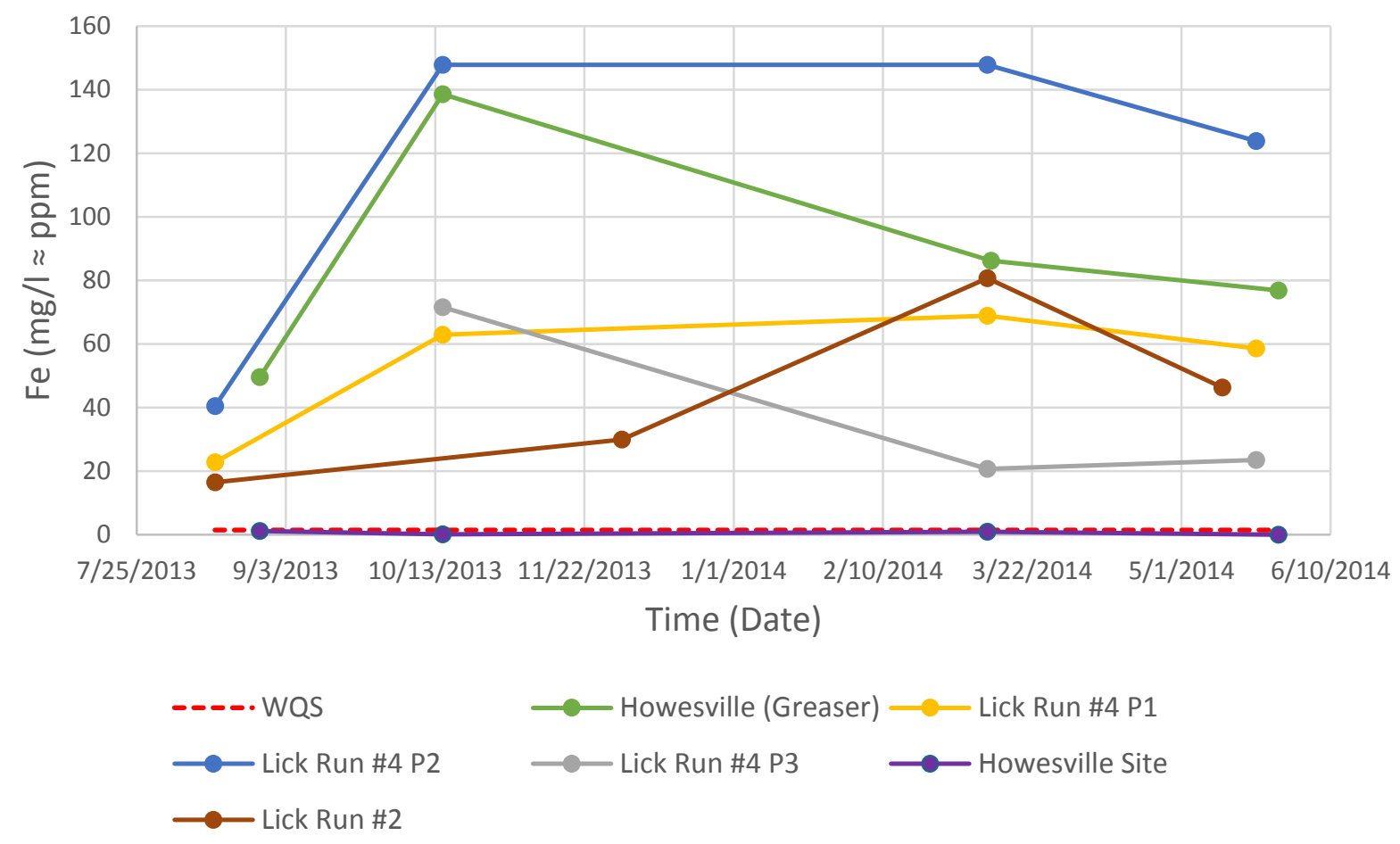

Figure 35: Mine Sites - Measured Fe Concentrations vs. WQS.

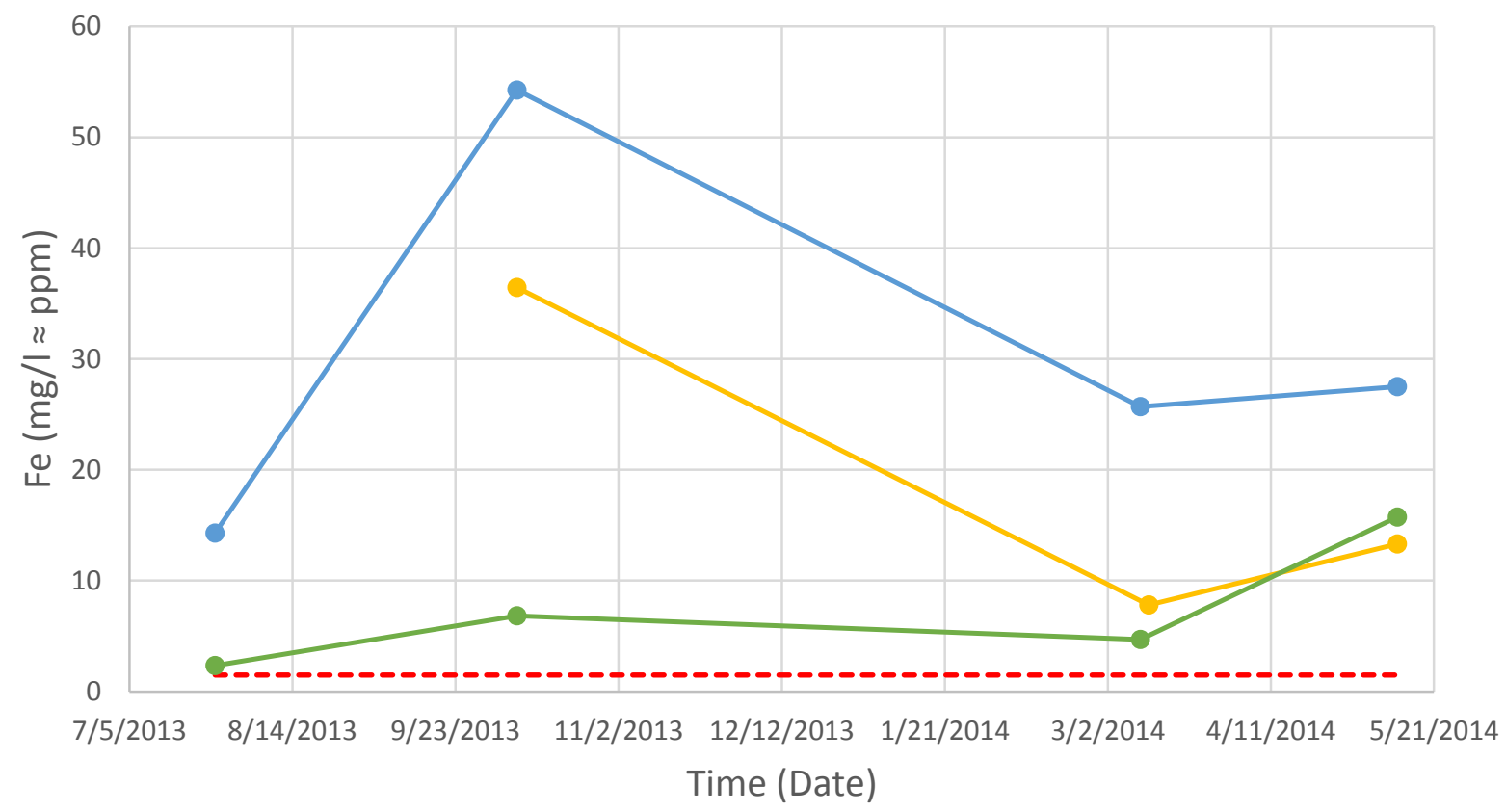

---..WQS $\longrightarrow$ Discharge Mouth $\longrightarrow$ Bottom Fork Middle $\longrightarrow$ Trib 1 DS

Figure 36: In-Stream Sites - Measured Fe Concentrations vs. WQS 

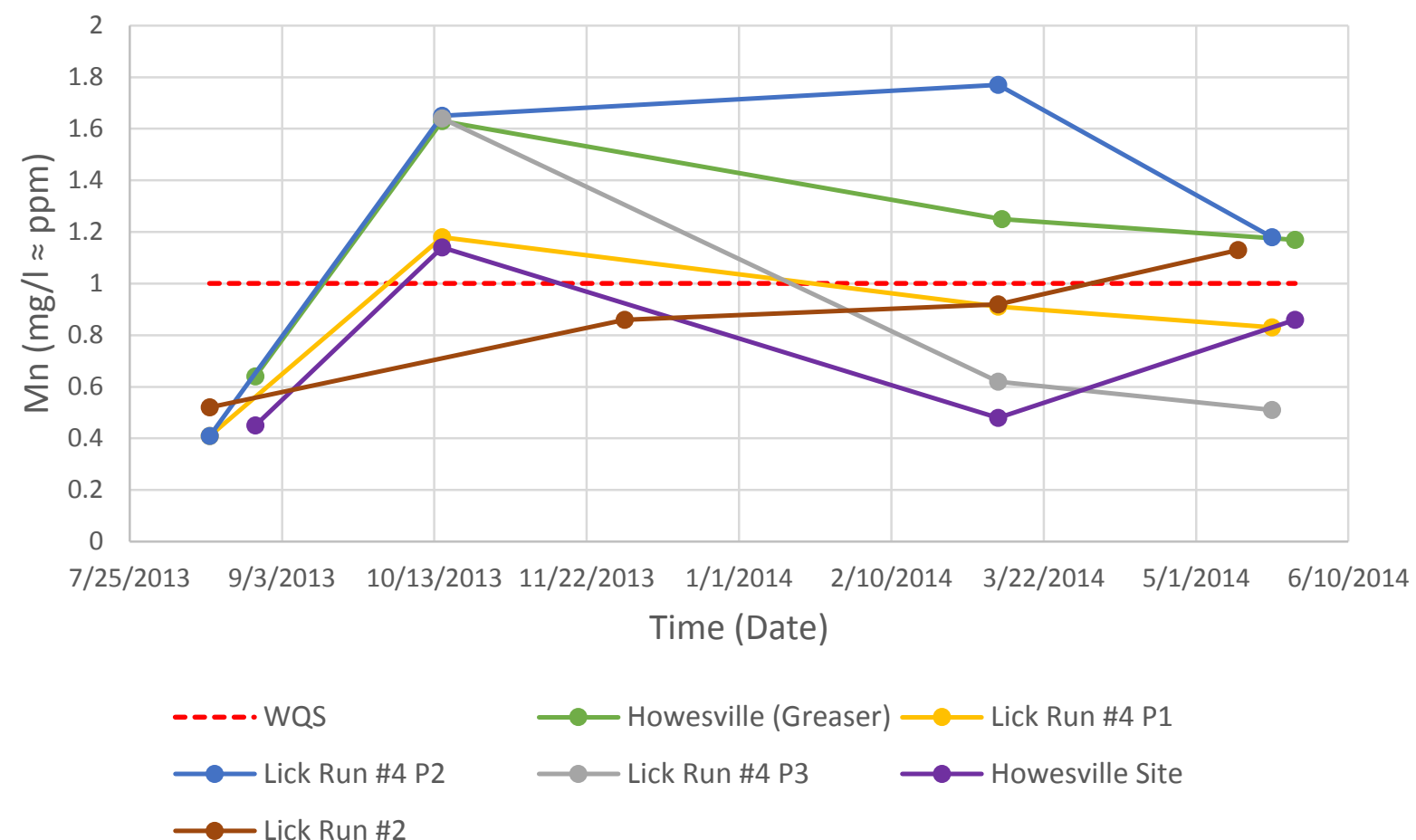

Figure 37: Mine Sites - Measured Mn Concentrations vs. WQS.

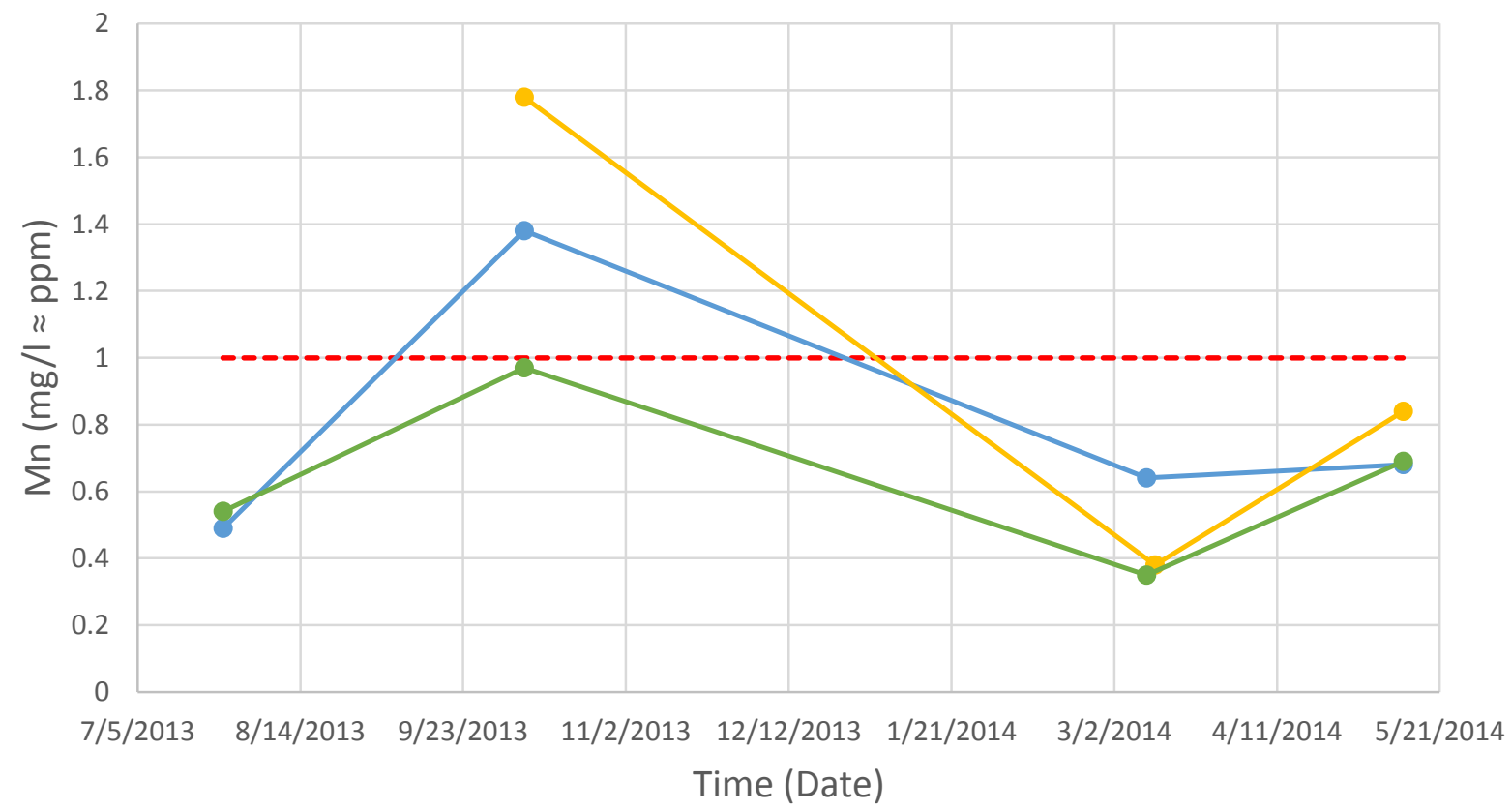

---..WQS $\longrightarrow$ Discharge Mouth $\longrightarrow$ Bottom Fork Middle $\longrightarrow$ Trib 1 DS

Figure 38: In-Stream Sites - Measured Mn Concentrations vs. WQS. 
Analysis of the mine site metal concentration charts show that aluminum and iron concentration levels are well above WQS for every site except for the Howesville Site, which is just about at WQS for every sample. In the case of Fe and Al, the Howesville Site is relatively not of concern when compared to the other sites. Manganese, on the other hand, is much closer to WQS for every site. In fact, most of the results for Mn concentration were within WQS, though, these results still imply a considerable effect on the watershed. Throughout all of the mine site charts, it is evident that the Lick Run \#4 P2 source is the single highest contributor of AMD to Lick Run's hydrology.

The in-stream sites, on the other hand, show a similar relationship to that of the mine sites. All of the in-stream samples showed $\mathrm{Al}$ and Fe concentrations to be well above WQS; Mn concentrations were mostly within WQS. Also, like with the mine sites, Fe concentrations were generally higher than Al concentrations. Finally, these charts show that the Lick Runs Discharge has the highest impairment of the three in-stream sample sites. This is because the Lick Run \#4 mine sites are not contributing to the mainstem until after the Trib 1 DS and Bottom Fork Middle sample locations.

\subsubsection{Effect of Lick Run Discharge on the Cheat River}

This section evaluates the effect of Lick Runs discharge on the Cheat River. The following figures present $\mathrm{pH}$ and metal concentrations by sample set for the Cheat River before and after Lick Run flows into it. Along with this, Lick Run's discharge is presented for comparison, providing a visual of the increase from upstream levels to downstream levels in the Cheat, which is caused by Lick Run. It can be seen that for every impairment, the Cheat River's metal concentration is considerably raised after Lick Run is contributed. Also, $\mathrm{pH}$ levels substantially decline after the convergence. Figure 39 shows pH comparisons, Figure 40 shows Al comparisons, Figure 41 is for Fe, and Figure 42 is for $\mathrm{Mn}$. 


$$
7
$$

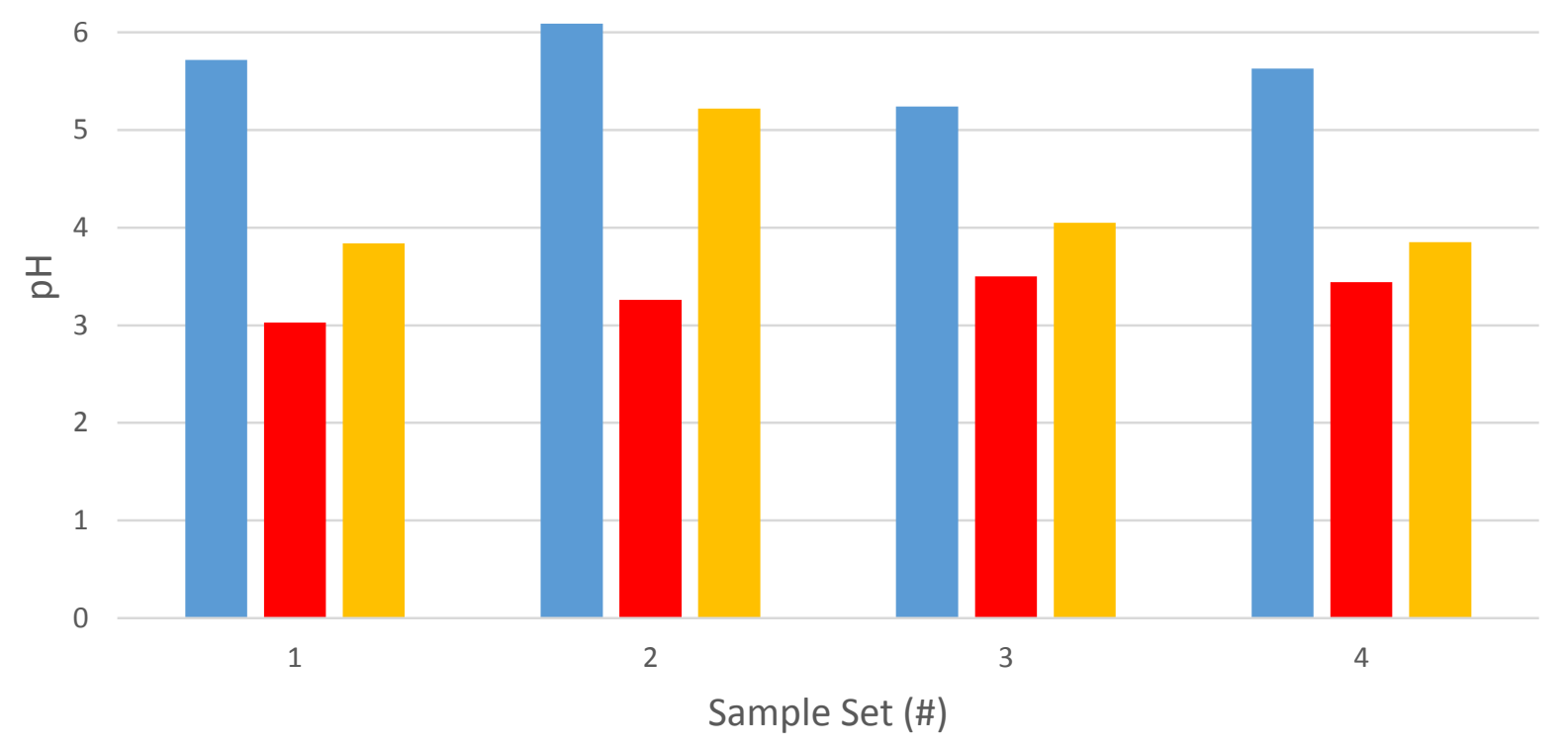

- Cheat River - Upstream of Lick Run $\quad$ Lick Run Discharge $\quad$ Cheat River - Downstream of Lick Run

Figure 39: Influence of Lick Run on the Cheat River - pH.

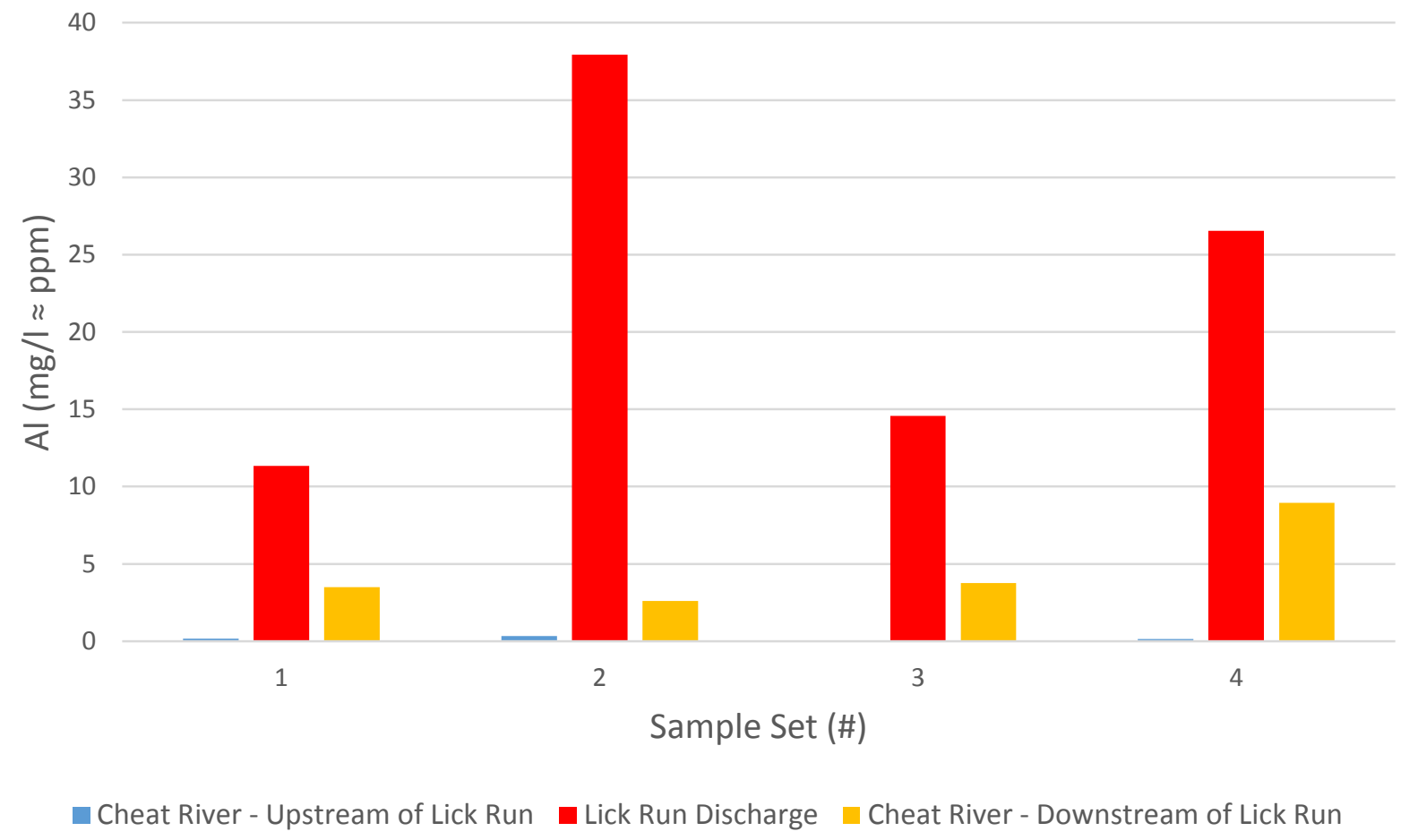

Figure 40: Influence of Lick Run on the Cheat River - Al. 
60

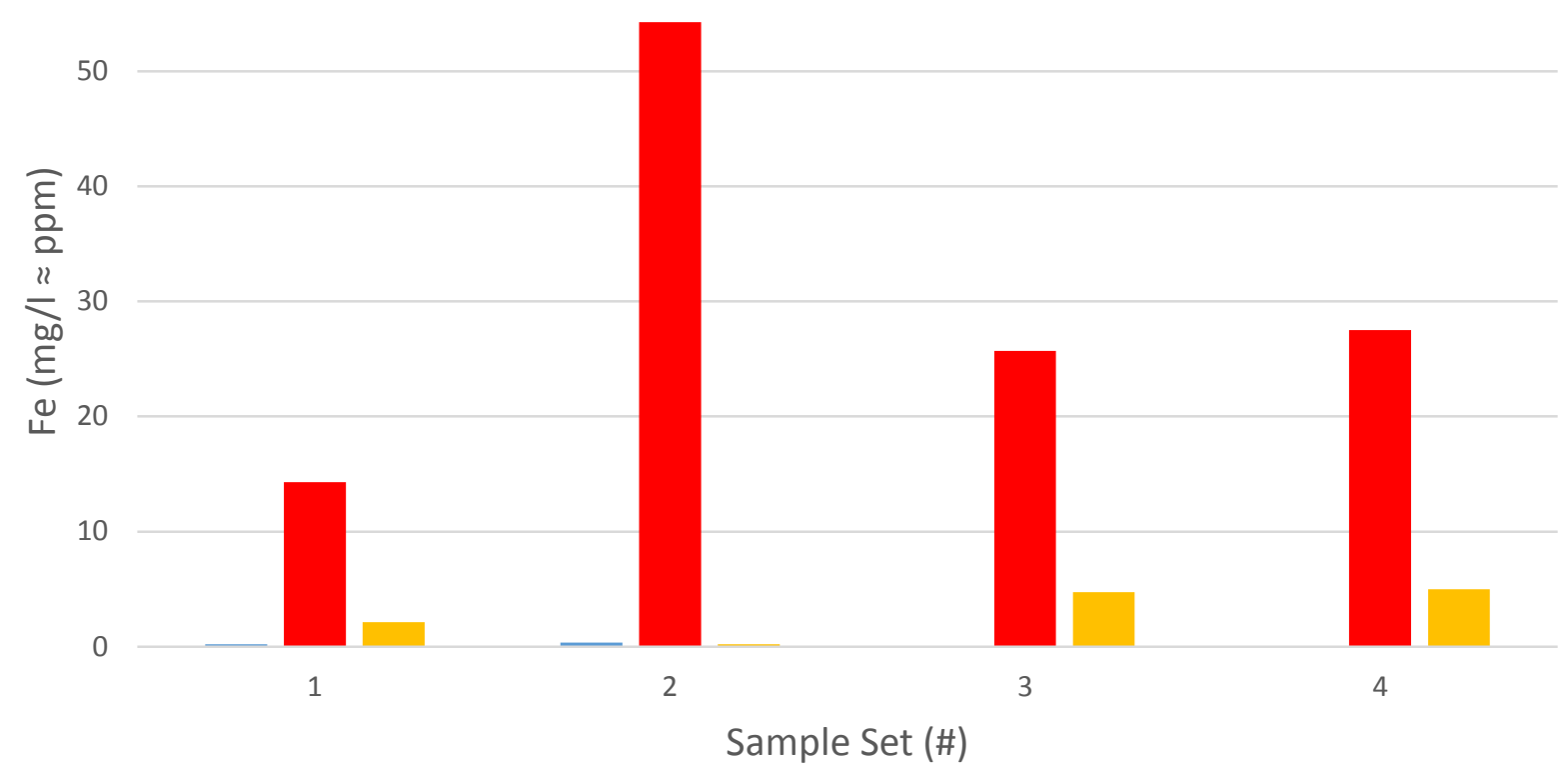

- Cheat River - Upstream of Lick Run $\quad$ Lick Run Discharge $\quad$ Cheat River - Downstream of Lick Run

Figure 41: Influence of Lick run on the Cheat River - Fe.

1.6

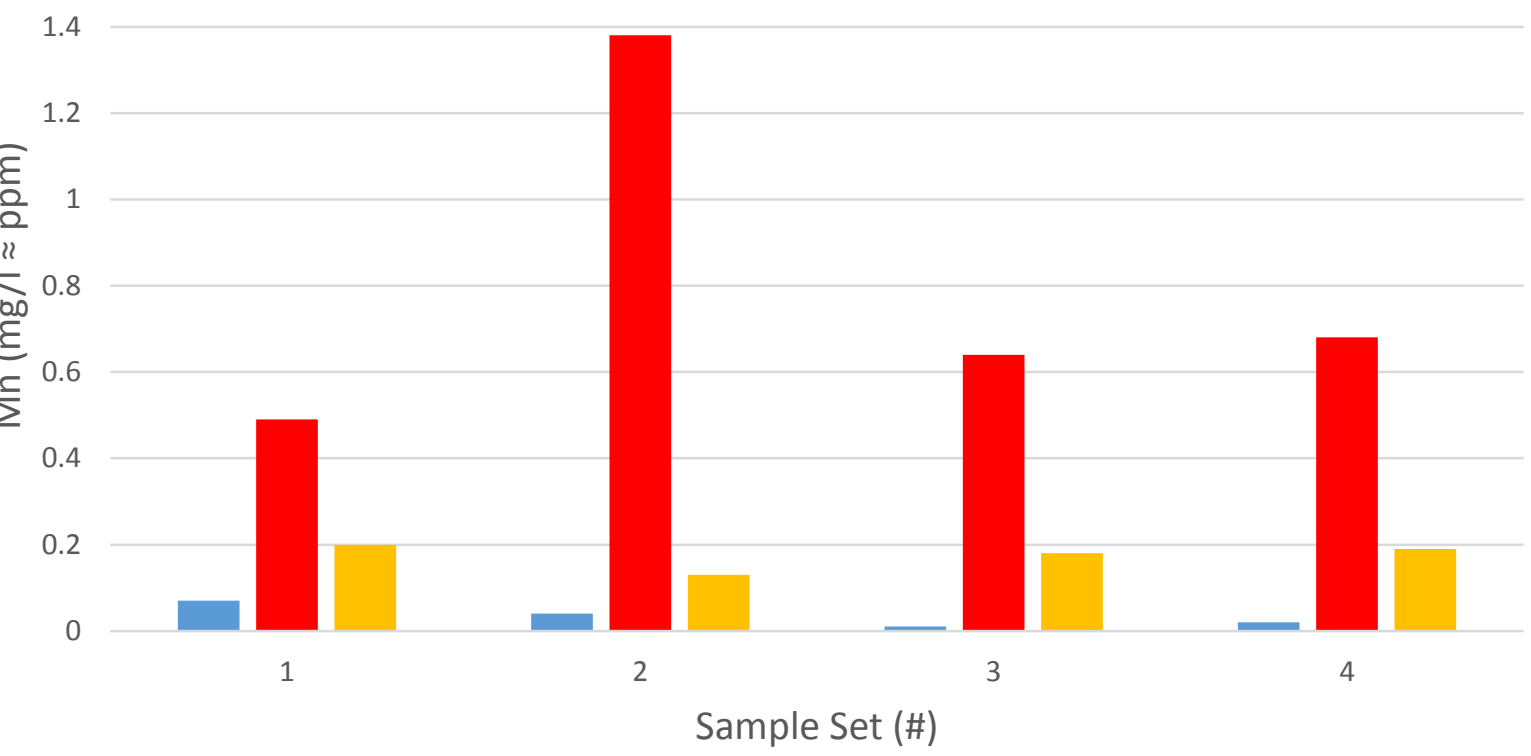

- Cheat River - Upstream of Lick Run $\quad$ Lick Run Discharge $\quad$ Cheat River - Downstream of Lick Run

Figure 42: Influence of Lick Run on the Cheat River - Mn. 
A picture of Lick Runs Mouth and discharge and the Cheat River bank, just after Lick Run converges, are shown below (Figures 43, 44, and 45). These pictures provide a good idea of how much Lick Run affects the Cheat River. The yellowish, orange precipitates on the rocks and boulders are metal hydroxides that have effectively armored the stream bank. These rocks are covered during high flow situations and Lick Runs water passes directly through this area during these times. As Lick Run waters mix with the cleaner waters from upstream, precipitation is further encouraged resulting in unnatural formations of metal throughout the aquatic environment.

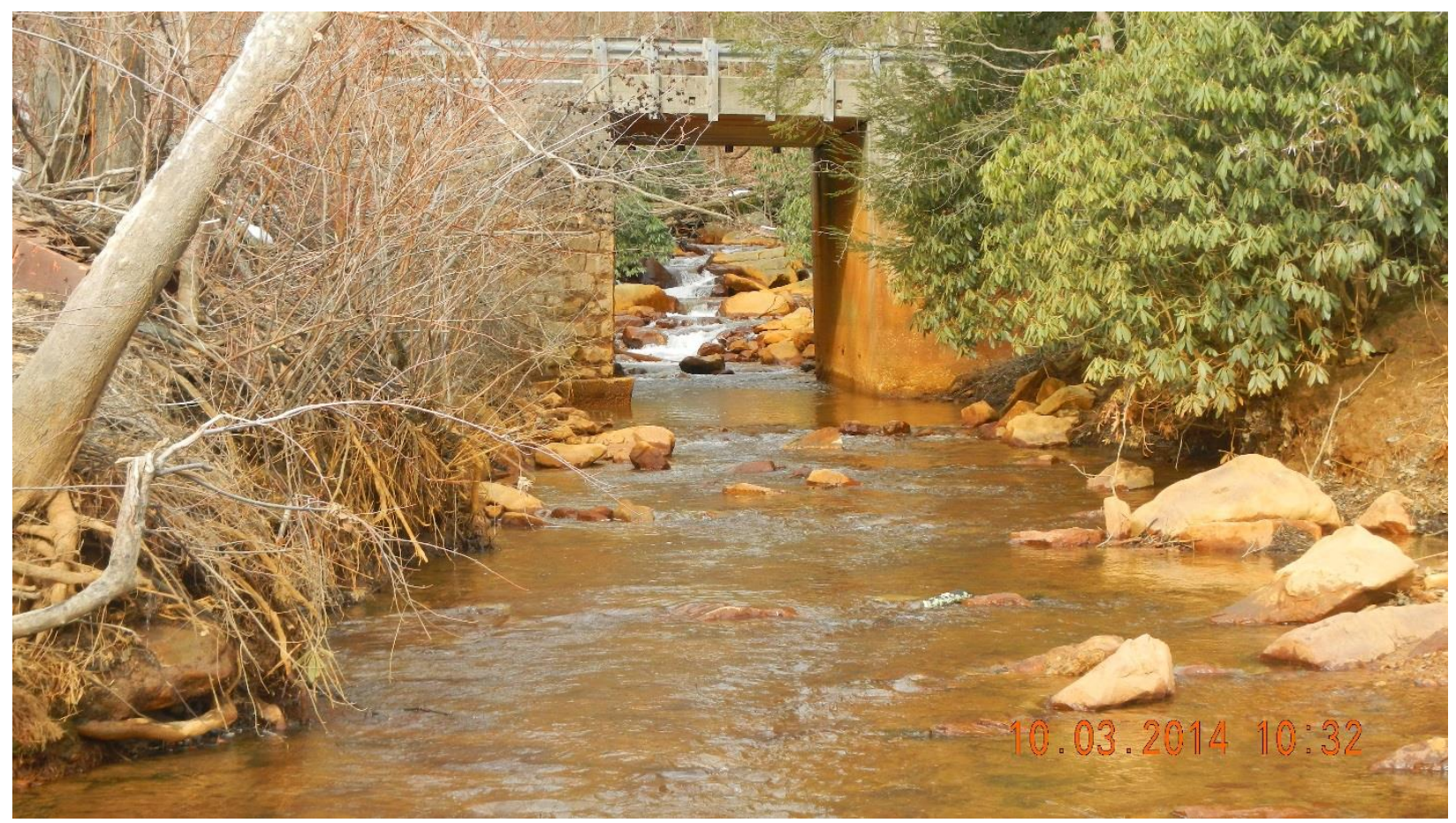

Figure 43: Lick Runs mouth and Discharge into the Cheat River. 


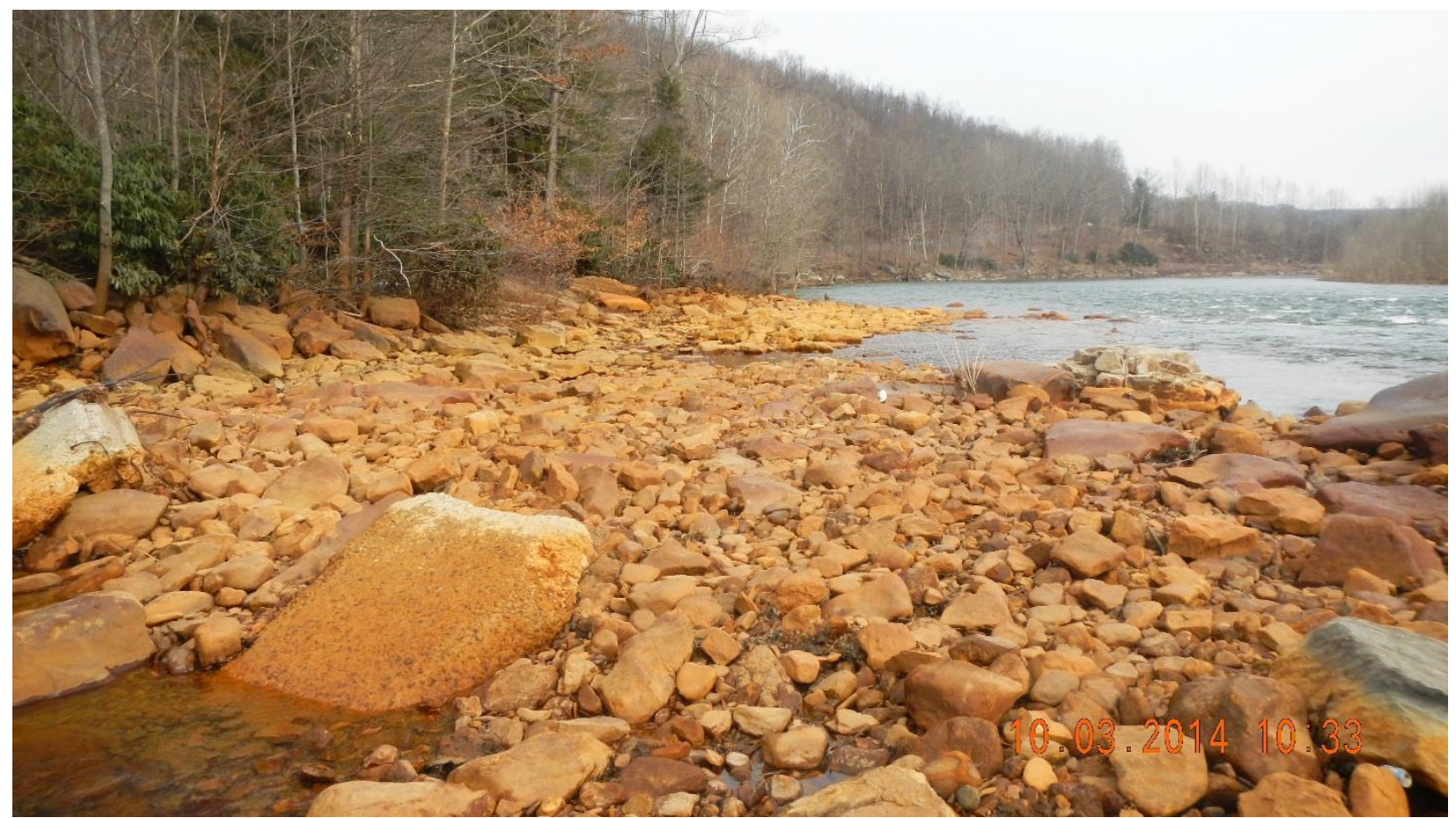

Figure 44: Cheat River bank, looking downstream. A small portion of Lick Runs discharge can be seen in the bottom left portion of the frame.

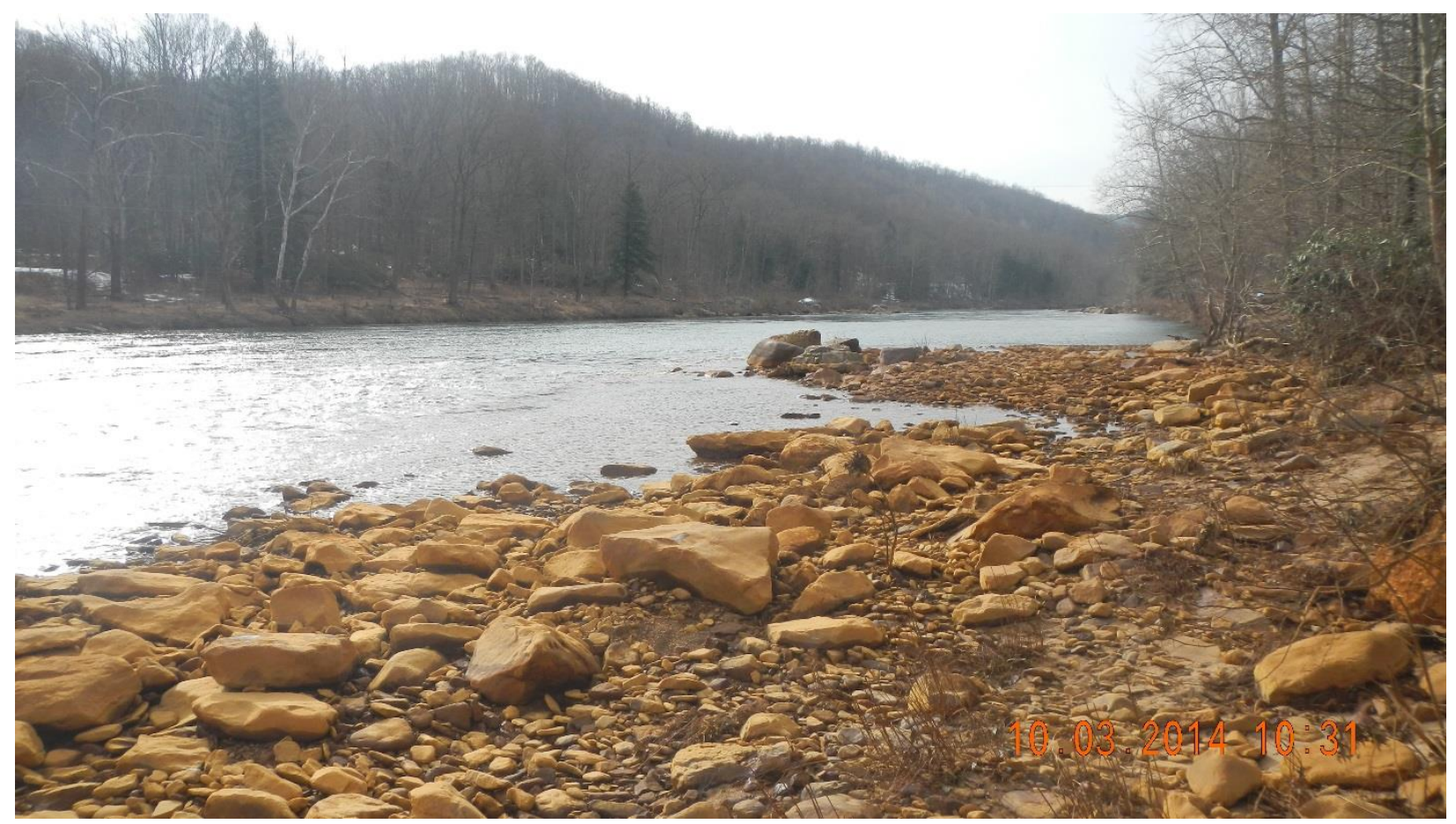

Figure 45: Cheat River Bank, looking upstream. Shot taken from below Lick Runs discharge; it can be seen that there is no apparent armoring or visible AMD effects on the Cheat River, prior to Lick Runs discharge. 


\subsubsection{Benthic Macro-Invertebrate Results}

The results from benthic macro-invertebrate testing is presented below (Table 8).

Table 8: Benthic Macro-Invertebrate Sample Results.

\begin{tabular}{|c|c|c|c|c|}
\hline \multicolumn{5}{|c|}{ WV329 (Lick Run) Benthic Sampling Results } \\
\hline \multicolumn{5}{|c|}{ Sample Set 1} \\
\hline \multirow{2}{*}{ Collection Date } & \multirow{2}{*}{ Site } & \multicolumn{2}{|c|}{ WVSCI Scores } & \multirow{2}{*}{ Integrity Rating } \\
\hline & & Point Value & Percentage Value & \\
\hline \multirow{3}{*}{$10 / 8 / 2013$} & Bottom Fork Middle & 12 & 40 & Marginal \\
\hline & Trib 1 DS & 6 & 20 & Poor \\
\hline & Discharge Mouth & 14 & 46.7 & Marginal \\
\hline \multicolumn{5}{|c|}{ Sample Set 2} \\
\hline \multirow{2}{*}{ Collection Date } & \multirow{2}{*}{ Site } & \multicolumn{2}{|c|}{ WVSCI Scores } & \multirow{2}{*}{ Integrity Rating } \\
\hline & & Point Value & Percentage Value & \\
\hline \multirow{3}{*}{$5 / 12 / 2014$} & Bottom Fork Middle & 6 & 20 & Poor \\
\hline & Trib 1 DS & 0 & 0 & Poor \\
\hline & Discharge Mouth & 0 & 0 & Poor \\
\hline
\end{tabular}

Only resilient benthic macro-invertebrates can survive within Lick Runs highly acidic waters. The highest WVSCl score was from Lick Runs discharge which was 46.7 for an integrity rating of marginal; this score was achieved by the presence of a single hellgrammite. The most common integrity rating in the watershed was poor; during the second sample set, Trib 1 DS and Discharge Mouth received a point value of 0 , which is the worst score possible. Individual sample WVSCI results and scores can be found in Appendix B.

\subsection{AMD Pollutant Loads Assessment}

\subsubsection{Existing Conditions and Pollutant Load Estimates}

As discussed in Section 5.1.1, four primary AMD producing sites have been located around Lick Run, contributing a total of six different sources/ portals-worth of pollutant loads to the watershed. The annual pollutant loadings for these sites are shown in Table 9; Table 10 shows annual pollutant loadings for the in-stream sampling locations. All of this data was created from at-least three samples apart from the asterisked $\left({ }^{*}\right)$ sites, as explained previously in Section 3.1.1. 
Table 9: Annual mine-site pollutant loadings $(n=4)$. Plus signs $\left({ }^{+}\right)$denote three sample values.

\begin{tabular}{|l|l|l|l|l|l|l|l|l|}
\hline \multirow{2}{*}{ Mine Sites } & \multicolumn{6}{|l|}{ Calculated } \\
\cline { 2 - 10 } & $\begin{array}{l}\text { Alk } \\
\text { tons/yr }\end{array}$ & $\begin{array}{l}\text { Acd } \\
\text { tons/yr }\end{array}$ & $\begin{array}{l}\text { SO4 } \\
\text { tons/yr }\end{array}$ & $\begin{array}{l}\text { Al } \\
\text { tons/yr }\end{array}$ & $\begin{array}{l}\text { Ca } \\
\text { tons/yr }\end{array}$ & $\begin{array}{l}\text { Fe } \\
\text { tons/yr }\end{array}$ & $\begin{array}{l}\text { Mg } \\
\text { tons/yr }\end{array}$ & $\begin{array}{l}\text { Mn } \\
\text { tons/yr }\end{array}$ \\
\hline \hline Lick Run \#2 & 0.007 & 7.09 & 7.83 & 0.404 & 0.546 & 0.632 & 0.187 & 0.013 \\
\hline Lick Run \#4 P1 & 0.550 & 573.54 & 770.41 & 38.05 & 51.55 & 58.56 & 22.22 & 0.915 \\
\hline Lick Run \#4 P2 & 0.752 & 1807.13 & 2281.00 & 72.74 & 107.07 & 172.87 & 44.28 & 1.88 \\
\hline Lick Run \#4 P3 ${ }^{+}$ & 0.831 & 539.30 & 896.22 & 39.64 & 79.75 & 64.08 & 26.06 & 1.53 \\
\hline Howesville Site & 1.22 & 6.51 & 15.18 & 0.384 & 4.14 & 0.094 & 0.798 & 0.120 \\
\hline Howesville Greaser & 0.054 & 64.92 & 66.12 & 2.41 & 4.23 & 9.43 & 0.92 & 0.126 \\
\hline
\end{tabular}

Table 10: Annual in-stream pollutant loadings $(n=4)$. Plus signs $\left(^{+}\right)$denote three sample values, asterisks $(*)$ denote single sample values.

\begin{tabular}{|l|l|l|l|l|l|l|l|l|}
\hline \multirow{3}{*}{ In-Stream Sites } & \multicolumn{6}{l}{ Calculated } \\
\cline { 2 - 10 } & $\begin{array}{l}\text { Alk } \\
\text { tons/yr }\end{array}$ & $\begin{array}{l}\text { Acd } \\
\text { tons/yr }\end{array}$ & $\begin{array}{l}\text { SO4 } \\
\text { tons/yr }\end{array}$ & $\begin{array}{l}\text { Al } \\
\text { tons/yr }\end{array}$ & $\begin{array}{l}\text { Ca } \\
\text { tons/yr }\end{array}$ & $\begin{array}{l}\text { Fe } \\
\text { tons/yr }\end{array}$ & $\begin{array}{l}\mathbf{M g} \\
\text { tons/yr }\end{array}$ & $\begin{array}{l}\text { Mn } \\
\text { tons/yr }\end{array}$ \\
\hline Discharge Mouth & 2.94 & 2105.04 & 3030.20 & 132.91 & 261.59 & 179.09 & 92.74 & 4.69 \\
\hline Bottom Fork Middle & 0.323 & 170.02 & 223.48 & 11.26 & 22.83 & 12.39 & 5.82 & 0.645 \\
\hline Trib 1 Mouth* & 0.203 & 78.61 & 94.06 & 5.32 & 16.24 & 1.43 & 4.25 & 0.183 \\
\hline Trib 1 US* & 0.846 & 192.54 & 236.85 & 10.96 & 30.42 & 6.68 & 8.68 & 0.829 \\
\hline Trib 1 DS & 1.56 & 338.39 & 463.62 & 20.35 & 63.67 & 23.04 & 17.16 & 1.98 \\
\hline
\end{tabular}

It should be noted that discrepancies in flow, loading, and concentration levels are mostly due to the fact that samples from each set were not taken on the same days. Flow levels can vary greatly from day to day; this is why the Discharge Mouth loadings are low compared to the total of all mine site loadings. Also, values presented in Tables 5, 6, 9, and 10 are averaged data from different amounts of sample sets.

It can be seen in Table 9 that the Lick Run \#4 site produces the largest volume of contamination. All three portals at this site produce significantly more pollutant loadings than the other mine sites due to their higher flow, lower $\mathrm{pH}$, and higher metal concentrations. All three of these portals put together contribute 295.51 tons/yr of Iron, 150.43 tons/yr of Aluminum, and 4.325 tons/yr of Manganese. Portal 1 (P1) has an average of a little over $3 \mathrm{pH}, \mathrm{P} 2$ sits at a little less than $3 \mathrm{pH}$, and $\mathrm{P3}$ enjoys the highest $\mathrm{pH}$ at about an average of 3.5. No other mine site pollutant loadings come close to these levels, mostly due to Lick Run \#4's relatively high flow.

The contribution of AMD from the Lick Run \#4 site can be seen in the Discharge of Lick Run into the Cheat River (Table 10). The mouth of Lick Run discharges with loadings at about 179.09 tons/yr of Iron, 132.91 tons/yr of Aluminum, and 4.69 tons/yr of Manganese. Iron and Aluminum loads are significantly lower than mine site allocations due to high concentrations of metals at the source. Water quality is at its worse right after AMD emerges from its source. As water 
makes its way through Lick Run's hydrologic system, it is treated by measures taken by AMLIS remediation, natural processes, and dilution.

\subsubsection{Identification of Critical Areas}

Figure 20 (page 45) illustrates the critical areas within the Lick Run watershed according to AMLIS, however, many of these sites have been remediated and/ or have low flow. Because of its relatively high flow, and high concentration, it is has become evident that the Lick Run \#4 site is by far the most critical area in the watershed, and requires the most immediate intervention. Analyzing the total average pollutant load allocations show that the combined Lick Run \#4 portals contribute $94.3 \%, 96.7 \%$, and $97.9 \%$ of Manganese (Mn), Iron (Fe), and Aluminum (Al), respectively, to the watershed. Granted, this does not account for all $\mathrm{Mn}, \mathrm{Fe}$, and $\mathrm{Al}$ that is produced in the watershed, but it gives a good idea of the extent of the Lick Run \#4 site's impact, as compared to the other major contributors to the watershed.

\subsection{Treatment Options}

\subsubsection{Existing Management Strategies}

Of the nine AMLIS sites within the Lick Run watershed, four of them have received funding for most, if not all of their problem descriptions, and have been remediated (Table 4); of these four sites, two of them have not had water quality issues that are recognized by AMLIS. The Philip Thorn HW, Howesville Site, and Lick Run \#2 all have existing management strategies for AMD, and use basic structural controls. These strategies include the controlled conveyance of AMD to local hydrology by the means of open limestone channels (OLCs) and the prevention of increased amounts of AMD through wet seals. OLCs help to decrease acid loads by increasing alkalinity and essentially begins treatment by subtly raising $\mathrm{pH}$ levels. Wet-seals prevent backflow of water from oxidizing further amounts of pyritic material, thus reducing AMD and in some situations preventing it (USDA NRCS 2005).

With all of this being said, AMD issues may or may not be shown by AMLIS, so this is not the best method for determining water quality. AMLIS is more involved with the physical safety aspects of abandoned mine lands' terrain and the leftover solid wastes that could be spread throughout the environment by water, wind, and all other forms of "Mother Nature" and wildlife.

The Howesville Site and Philip Thorn HW have water quality issues that are recognized by AMLIS as polluted water: agricultural and industrial. The Howesville Site affects the Southern Start Tributary, however, which is not on the 2011 Cheat River TMDL for metals impairment (Tetra 
Tech 2011). Also, testing results showed concentrations that met iron and manganese water quality standards, but not aluminum, which was very close and significantly lower than all other mine sites and in-stream sites. Because of these two factors, the Howesville site is not a target treatment location for the WBP's remediation strategy. AMLIS remediation of this problem area is set to occur by 2016 and could result in the restoration of this sites water quality. The Philip Thorn HW, on the other hand, is in a location that is inaccessible for the scope of this project, so was left untested. According to AMLIS, the polluted water problems at this site have been remediated, and it is suspected that AMD from this source could meet water quality standards; either way, it will receive treatment further down Lick Run's hydrology.

None of these structural controls are sufficient for treating AMD emanating from mine portals. All of the other sites have not received any funding nor have had any structural controls installed. Two sites of great importance to the remediation of Lick Run is the Howesville (Greaser) Portals and Dr and the Lick Run Portal \#4 sites. These are both listed on AMLIS for "Water Problems" and testing performed by WVWRI support this, revealing low $\mathrm{pH}$ levels and significantly high iron and aluminum concentrations, with manganese concentrations also not meeting WQS. These two sites have the highest priority in Lick Run and have received zero funding, nor remediation from the Office of Abandoned Mine Lands. They are, however, on the AMLIS list of "things-todo"; all AMLIS problem areas should be remediated prior to water quality controls being installed.

\subsubsection{Additional Strategies Needed to Achieve Water Quality Standards}

The following conceptual designs are based on data collected for use in a watershed based plan for the WVDEP. These designs incorporate past WVWRI strategies as well as strategies produced by my own research efforts. They utilize the limited capabilities offered by ArcGIS Maps and AMD Treat to help asses various factors such as watershed characteristics, optimal dimensions of treatment modules, and appropriate limestone loads needed to beneficially raise pH levels. These systems apply combinations of treatment modules that are presented in the Literature Review of this report in order to neutralize acidity, raise $\mathrm{pH}$, and precipitate metals. The goal of these projects are to achieve $80 \%$ acid load reduction, which will cause a significant decrease in metal loads and concentrations, bringing water quality close to, if not within WQS.

Due to the limited capabilities discussed in Chapter 2 of this report, all values and results are the products of educated and model assisted estimates that are as accurate as technology and the scopes of this project would allow. Cost estimates were generated by AMD Treat using default global values such as $22 \$ /$ ton of limestone, $20 \$ / y^{3}$ of organic matter for wetlands, and 5.50 $\$ / y d^{3}$ for excavation. Limestone quality defaults were $90 \%$ purity at $60 \%$ efficiency. All systems are designed with a 20 year lifespan. 


\section{General Treatment Plan/ Systems Overview}

The general treatment plan that will be proposed for the remediation of Lick Run is as follows. Four systems comprised of 5 modules are presented, all of which, if installed, will supplement the already installed modules that have been set in place by the WVDEP, Office of Abandoned Mine Lands. If a site is on the AMLIS to-do list, WVWRI and WVDEP will work together to make sure that AMLIS priorities are taken care of prior to the installation of the proposed systems from the WBP. All of these systems will follow the same modular arrangement including the use of a limestone leach bed, a settling pond, an aerobic wetland, and two open limestone channels for conveyance. After being sent through the entire set of systems, an increase in $\mathrm{pH}$ to at least 6 is expected. A reduction of at least $80 \%$ of acid and metal loads is also expected.

Each system that is suggested to be installed have been designed to cost as little as possible, while still meeting $\mathrm{pH}$ and load reduction requirements. The use of passive treatment systems with sustainable influence was determined to be the best course of action for remediating Lick Run. Along with this, the systems are designed to keep the area as natural looking as possible; in order to achieve this, clay liners will be used as opposed to synthetic liners, limestone beds and settling ponds will be constructed to look natural, and an aerobic wetland will be installed as a finishing touch. Aerobic wetlands will not only help to instill a natural feel to the systems, but also provide great amounts of habitat for wildlife, nutrients for the surrounding area, and effective water quality treatment.

AMD Treat v5.0+ was used to model the proposed treatment systems based on water quality and quantity data that was presented in this report. The average flow found from the quarterly sampling period was used as the typical flow; design flow was calculated by adding $10 \%$ to the typical flow as a factor of safety to help account for high flow situations. AMD Treat provides basic cost analysis built on norms and averages from past treatment/ construction efforts, and was developed by the Office of Surface Mining Reclamation and Enforcement. Individual system cost analyses are products of estimated excavation costs, clearing and grubbing costs, a 20 year sludge removal cost, organic matter and limestone fees, liner fees, and a $12 \%$ engineering cost that accounts for transportation to Lick Runs rural location, among other factors. These systems possess a 20 year expected lifespan, after which all modules should be inspected and sludge should be removed.

If all AMLIS priorities were addressed, and the installation of the following proposed systems complete, the path of AMD from its emergence to its release through a single system would be as follows: AMD first emerges from its portal(s) and is directly picked up by WVDEP OLC(s). From these OLCs, AMD will either be sent to local hydrology or directly into the beginning of one of the proposed treatment systems. If sent into local hydrology first, the AMD will enter a system shortly after all target waters in that area have been collected, or sufficient space for treatment becomes available. The first cell/ module in each system is a limestone leach bed, which will initiate adequate treatment mechanisms by increasing alkalinity, thus decreasing acid loads and encouraging the precipitation of metals. From here, AMD will flow into the first of two new OLCs and be conveyed to a settling pond. The settling ponds will provide ample space and retention time during which much of the target metals will drop out of solution and collect on the bottom 
of the pond as a sludge. After this, AMD will flow into the second OLC and be conveyed to the final cell, the aerobic wetland. After the wetlands, the resulting water will be greatly enhanced and will make its way to the next system, or to Lick Runs discharge. A closer look at the individual modules is presented below.

\section{Limestone Leach Bed (LLB)}

All of the LLBs were designed around a retention time of 1.5 hours. This is for a couple of reasons, the first being that limestone leach beds have been designed this way by WVWRI in past restoration efforts. Though my research has shown that alkalinity producing systems should use retention times of up to a day or more, it is expected that these smaller LLBs will incur less armoring, thus will last longer and require much less maintenance. Lick Run's hydrology is generally acidic, but is usually just below the required $\mathrm{pH}$ of 4 , that which allows oxidation and removal mechanisms to take place. Because of this, $\mathrm{pH}$ levels need only to be raised marginally compared to that of metal removal; therefore the LLBs for these systems have been designed around longevity and sustainability and to initiate chemical reactions that will be amplified downstream in the settling pond. All LLBs were designed to have $3 \mathrm{ft}$. of crushed limestone, $2 \mathrm{ft}$. of free standing water, and $3 \mathrm{ft}$. of freeboard depth with side slopes ratios of 2:1.

\section{(Limestone) Settling Pond}

The settling ponds for this report have been designed around a retention time of 24 hours to provide a place for sediment and hydroxide precipitates to accumulate. This way, much of the resulting sludge from treatment is easily accessible for removal after the 20 year life cycle. These ponds, in supplement with the LLBs, also acknowledge pre-treatment considerations that are offered in the literature review of this report. If $\mathrm{pH}$ is not at preferred levels, limestone can be added to these ponds to further treat acidity and promote oxidation and metal precipitation. The settling ponds were designed with a water depth of $4 \mathrm{ft}$., a freeboard depth of $2 \mathrm{ft}$, and side slope ratios of 2:1.

\section{Aerobic Wetland}

Aerobic wetlands in this report have been designed around metal removal rates and land requirements. Because these systems require such an immense plot of land in order to be designed by metal removal rates, all of the systems were cut down to a more reasonable size, thus designed by dimensions. AMD Treat designs individual modules based on the overall flow characteristics of the system input. Since flow characteristics are unchanged by each pre-acting module, it is safe to assume that each system would be over-treating from an input point of view; because of this, and the fact that multiple systems are used throughout Lick Run, it is assumed that hefty reductions of these wetland areas would still reach the goals employed by the encompassing remediation strategy. Plants used should be those species that form dense stands or litter zones with high nutrient and mineral sorption capabilities. Cattails and bulrushes are two favorable species that are commonly used as discussed in Section 2.3. Each wetland is designed to have $1 \mathrm{ft}$. of engineered organic matter, $0.5 \mathrm{ft}$. of free standing water, $1.5 \mathrm{ft}$. of freeboard depth, and a side slope ratio of 2:1. Individual wetlands will have different retention times based on the amount of flow and potential metal loads that the site is to ingest. 


\section{Open Limestone Channels (OLCs)}

Open limestone channels are used primarily for conveyance purposes. They are relatively cheap, costing only $\$ 4,392$ for both OLCs at each location. These cost estimates were determined using an arbitrary length of 100 feet for each OLC, and the bottom width of these modules were designed to be $4 \mathrm{ft}$. with side slope ratios of 2:1, creating a depth of $3 \mathrm{ft}$. Because OLCs contribute little treatment when compared to the other modules, their involvement is negligible and altering the dimensions of each OLC will have little relative affect to overall costs.

Of the four systems that are presented below, the Howesville Greaser and Lick Run \#4 treatment systems have the highest priority and are considered mandatory for the remediation of Lick Run. The other two systems, the Middle Start and Trib 1 DS systems, are lower priority and are considered optional. These sites should be implemented on the basis of time, funding, and further testing. The Middle Start Tributary is on the 2011 Cheat River TMDL for $\mathrm{pH}$ and metal contamination (Tetra Tech 2011). WVWRI strongly suggests that the Middle Start site be considered for approval; the data for this site is good, but not exact, due to the implementation being at the headwaters, whereas testing was done midway through the tributary. Trib 1 Mouth and Trib 1 US data, on the other hand, are less certain because they are based on a single sample's results; testing of Trib 1 DS was originally thought to be the Mouth, which was the desired sample location. Because of this, a treatment system was developed based on the DS data that has averages based on four sample results.

Trib 1 is an unmarked and unnamed tributary to Lick Run that possesses considerable flow with visible AMD contamination. Along with this, the single sample taken from the mouth of Trib 1 revealed concentrations of $3.53 \mathrm{mg} / \mathrm{l}$ of iron and $13.10 \mathrm{mg} / \mathrm{l}$ of aluminum, which are both well over WQS and imply heavy AMD contamination. The manganese concentration, however, was only $0.45 \mathrm{mg} / \mathrm{l}$, which meets water quality standards (Section 3.3.2). A picture of Trib 1's discharge into Lick Run is presented in Figure 46; Figure 47 shows a picture taken in Lick Run's mainstem, at Trib 1s conflux, looking downstream. With the data that is available, it has been determined that treatment in the mainstem would be more appropriate than treating Trib 1 by itself. WVWRI strongly suggests that Trib 1's Mouth be further tested for the development of a treatment plan for it alone, before it flows into Lick Run's mainstem. This would significantly cut back on the cost of this sites treatment system, the space required to perform the treatment, and would not affect the overall remediation of Lick Run because this part of Lick Run's mainstem is treated by the Lick Run \#4 system further downstream. Having no system installed at this location is a viable option as well; the overall results from the other three systems on Lick Run's discharge into the Cheat River would still be expected to be about $80 \%$ reduction of acid and metal loads, with a resultant $\mathrm{pH}$ level above 6. 


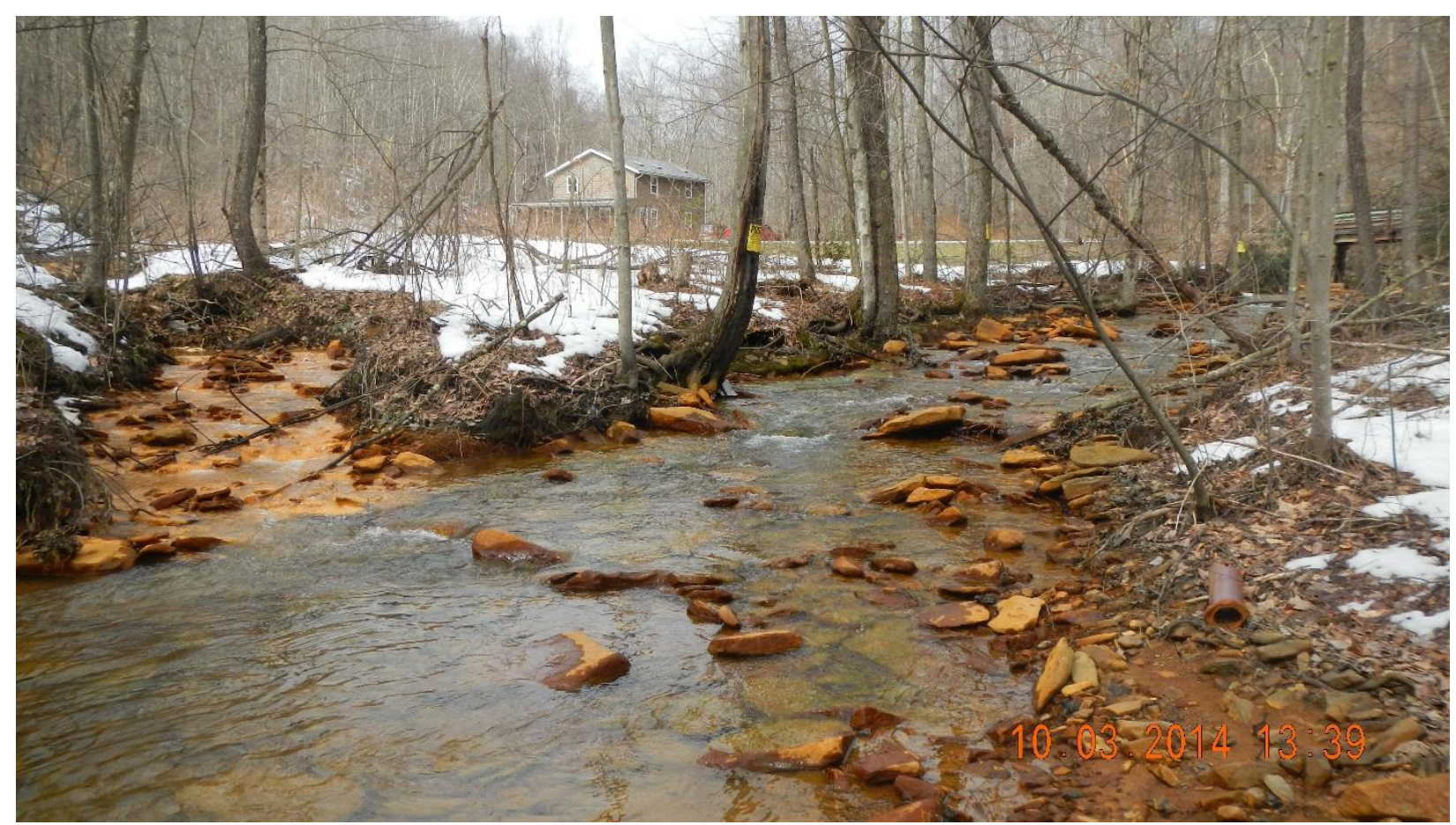

Figure 46: Trib 1s discharge into Lick Run, looking upstream. Trib 1 is located on the left side of the shot.

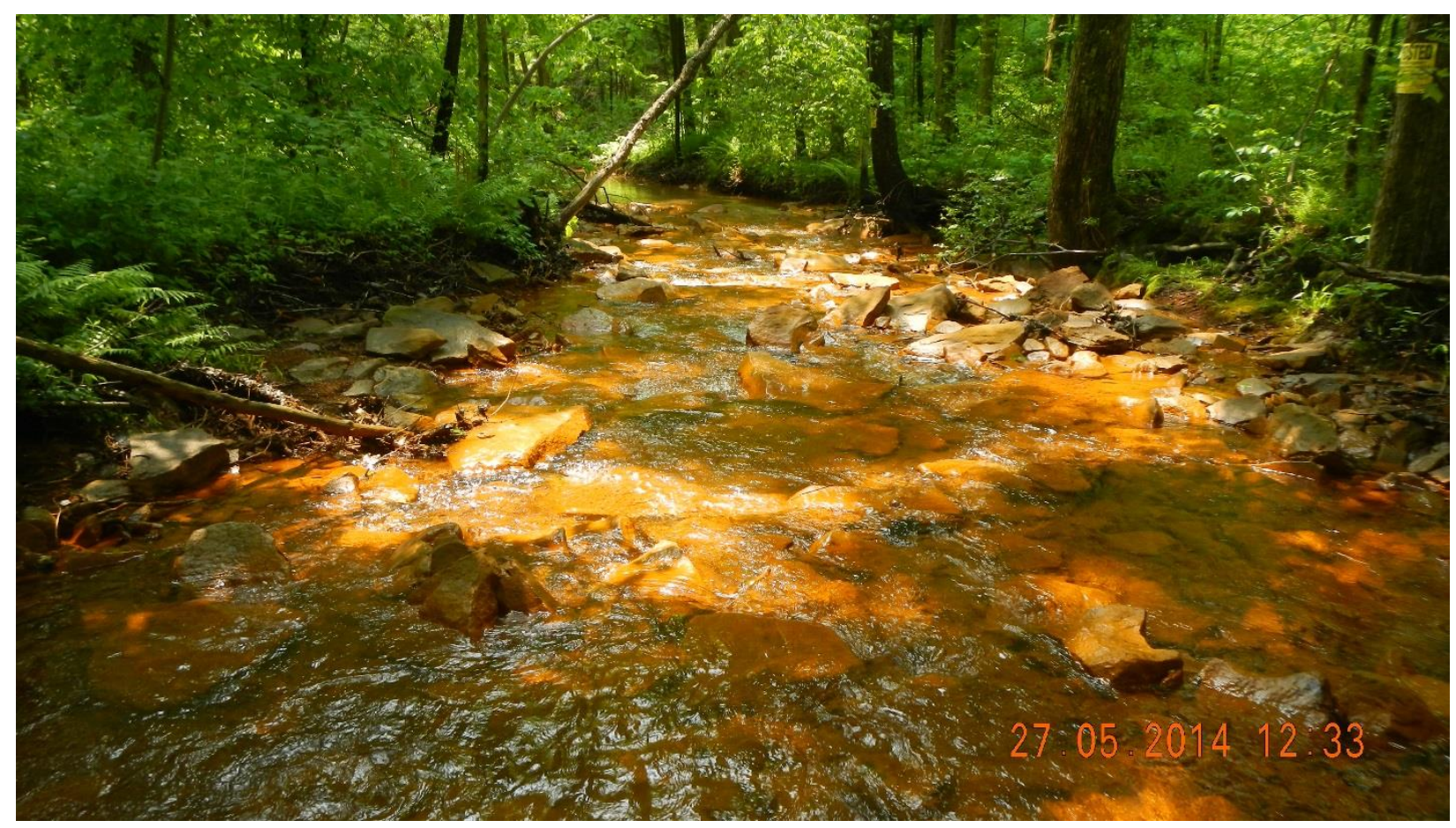

Figure 47: Lick Run mainstem at Trib 1s conflux, looking downstream.

A more detailed look into the individual systems are presented as follows; AMD Treat reports for each site are provided in Appendix C: 


\section{Howesville Greaser}

The Howesville Greaser site is located in the headwaters of Lick Run's mainstem. This site produces about $18,860 \mathrm{lbs} / \mathrm{yr}$ of iron, $4,820 \mathrm{lbs} / \mathrm{yr}$ of aluminum, and $252 \mathrm{lbs} / \mathrm{yr}$ of manganese at an average $\mathrm{pH}$ of 3.0 and a typical flow of $49 \mathrm{gpm}$, which calls for a design flow of $54 \mathrm{gpm}$. Because these metal loads are high, and the $\mathrm{pH}$ is low, a treatment system is vital at this location. The treatment system will follow the general treatment plan/ system overview; the limestone leach bed was modeled in AMD Treat to be about (60.5 ft. x $40.25 \mathrm{ft}$.), the settling pond was estimated to be about ( $300 \mathrm{ft}$. by $150 \mathrm{ft}$.), and the aerobic wetland was given a projected ( $300 \mathrm{ft}$. $x 150 \mathrm{ft}$.) dimension with a $48 \mathrm{hr}$ retention time. The aerobic wetland area was sized down to about $68.1 \%$ of which was produced by AMD Treat when designing by metal removal rates. The total estimated cost of this system with all of its modules is about $\$ 87,176$. A reduction in metal loads to at least 3,772 lbs/yr of iron, $964 \mathrm{lbs} / \mathrm{yr}$ of aluminum, and $50.4 \mathrm{lbs} / \mathrm{yr}$ of manganese is expected; $\mathrm{pH}$ would increase to a minimum of at least 6 . A conceptual sketch of this system is shown in Figure 48.

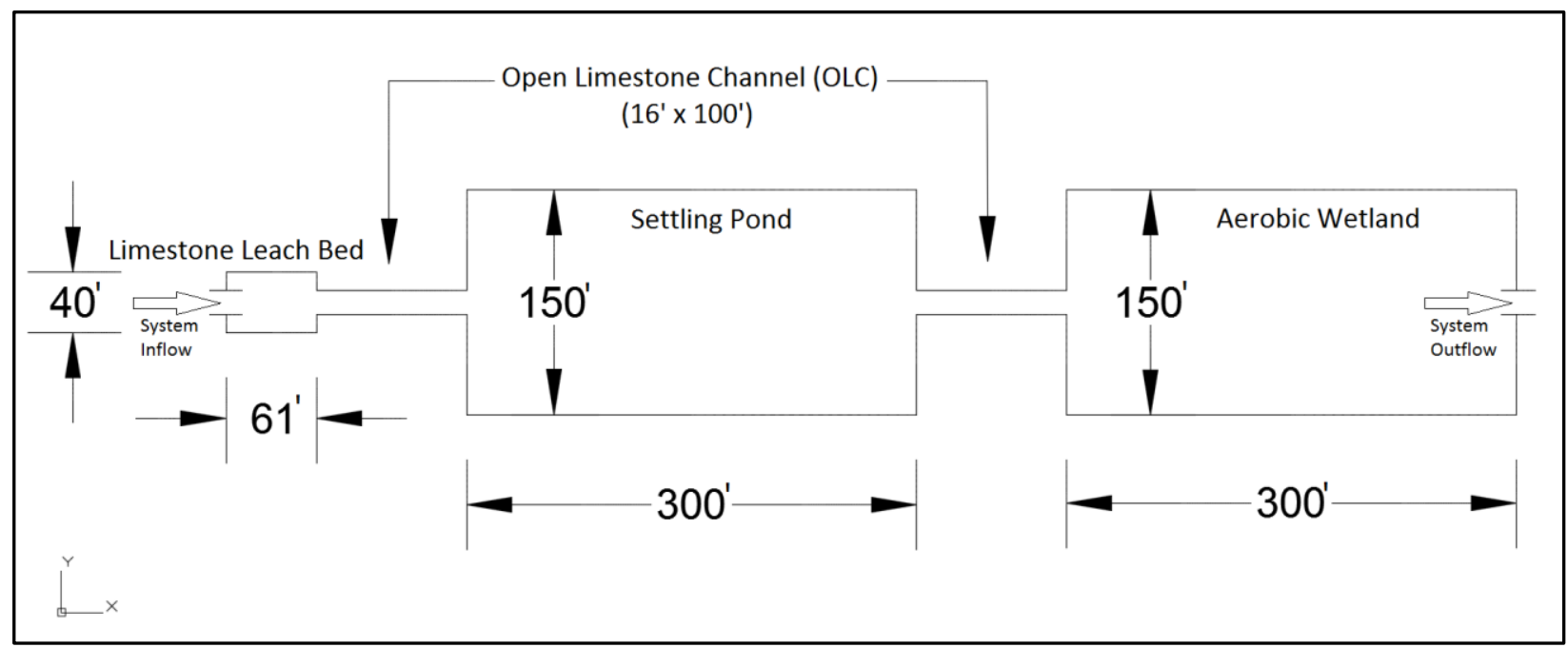

Figure 48: Conceptual sketch of the Howesville Greaser remediation system.

\section{Lick Run \#4}

As mentioned before, the Lick Run \#4 site is the largest producer of AMD and the most prominent problem area in the watershed, thus requiring the most amount of attention. This site has three different nonpoint sources of pollution located within about 50 yds. of each other, two of which are directly linked to open portals, and a third that emanates out from underneath a large rock outcrop in the mouth of the Middle Start Tributary. All three of these sources will be treated at the same time, along with all of the waters associated with Like Runs mainstem, just below the bottom fork. This site will include the largest treatment modules in order to compensate for the highest amount of flow, low $\mathrm{pH}$ value, and significantly high metal loads. To get the desired flow and metal load values for this system, all three Lick Run \#4 portals and Trib 1 DS data were added together. This site will be dealing with an estimated $\mathrm{pH}$ of about 3.39 and will have metal loads of about $637,111 \mathrm{lbs} / \mathrm{yr}$ of iron, $341,559 \mathrm{lbs} / \mathrm{yr}$ of aluminum, and 12,633 lbs/yr of manganese, with a typical flow of 3,361 gpm ushering a design flow of 3,700 gpm. $\mathrm{PH}$, and water quality concentrations (including metals), were calculated by a flow weighted average; water quality 
concentrations are used in AMD Treat for modeling purposes. In order to sufficiently treat these parameters, a limestone leach bed with estimated dimensions of about ( $292 \mathrm{ft}$. x $156 \mathrm{ft}$.), a settling pond at approximately ( $961 \mathrm{ft} . \times 484 \mathrm{ft}$.), and an aerobic wetland of about (1000 ft. x 500 $\mathrm{ft}$.) with a retention time of 8 hours were modeled, and would be necessary. This aerobic wetland area was resized to about $22 \%$ of which was suggested when designing by metal removal rates in AMD Treat. This large decrease was performed in order to compensate for the massive amount of land that would be necessary for treatment based on removal rates. The loss of treatment due to this should be canceled out by the preceding treatment systems in Lick Run's watershed, as well as the pretreatment modules applied to this wetland within this system itself. The implementation of the general treatment plan/ system overview, with these model generated dimensions at this site, will cost about $\$ 1,529,850$. This system is expected to create a reduction in metal loads to be at least $127,422.2 \mathrm{lbs} / \mathrm{yr}$ of iron, $68,311.8 \mathrm{lbs} / \mathrm{yr}$ of aluminum, and 2,526.6 lbs/yr of manganese, or more; $\mathrm{pH}$ would increase to a minimum of at least 6 . A conceptual sketch of this system is shown in Figure 49.

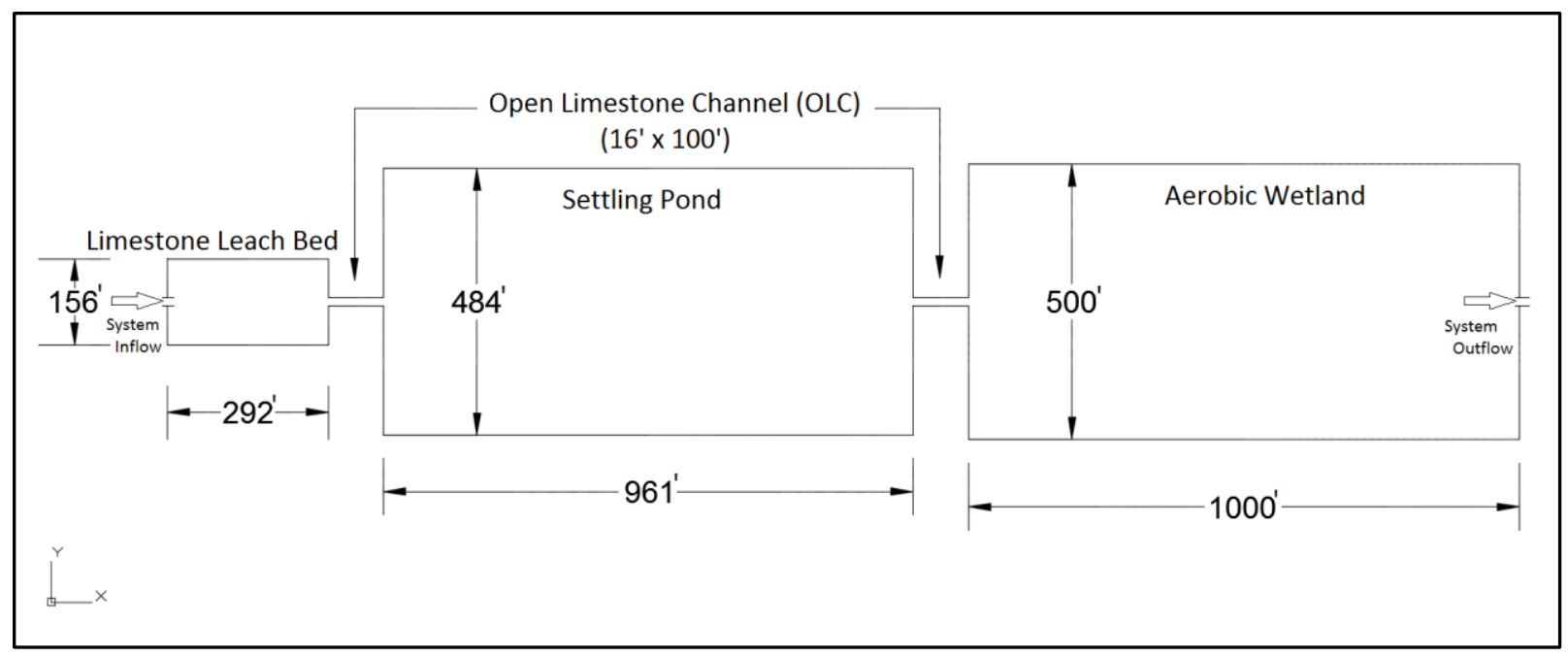

Figure 49: Conceptual sketch of the Lick Run \#4 remediation system.

\section{Middle Start}

Another suggested treatment location for Lick Run is at the Middle Start Tributary headwaters. This tributary is on the Cheat River TMDL for AMD impairment and WVWRI testing results support this. At the top of the Middle Start Tributary is the Leona Nicholson abandoned mine land. This site produces no water quality concerns according to AMLIS, but water quality results from samples taken midway through the tributary shows that it is indeed infected. The results from the Bottom Fork Middle testing efforts will be used to treat the headwaters of the Middle Start Tributary. This data shows an estimated pH of about 3.47 with metal loads to be about 24,780 $\mathrm{lbs} / \mathrm{yr}$ of iron, $22,520 \mathrm{lbs} / \mathrm{yr}$ of aluminum, and $1290 \mathrm{lbs} / \mathrm{yr}$ of manganese. The typical flow at this location is about $294 \mathrm{gpm}$ and can be expected to be less at the headwaters; because of this, the design flow was not multiplied by the factor of safety of $1.1(10 \%)$, but was rounded up to be 300 gpm instead. With all factors considered, AMD Treat generated estimated cell dimensions of about ( $104 \mathrm{ft}$. by $62 \mathrm{ft}$.) for the limestone leach bed, a (254 ft. x $131 \mathrm{ft}$.) settling pond, and a (400 $\mathrm{ft}$. $x 200 \mathrm{ft}$.) aerobic wetland that would have a retention time of about 15 hours. This wetland 
area was cut down to about $74.8 \%$ of the area suggested my AMD Treat when designing by metal removal rates. The total cost of this system would be about $\$ 166,822$. Effluent metal loads would be about 4,956 lbs/yr of iron, 4,504 lbs/yr of aluminum, and $258 \mathrm{lbs} / \mathrm{yr}$ of manganese, or better; $\mathrm{pH}$ would increase to a minimum of at least 6 . A conceptual sketch of this system is shown in Figure 50.
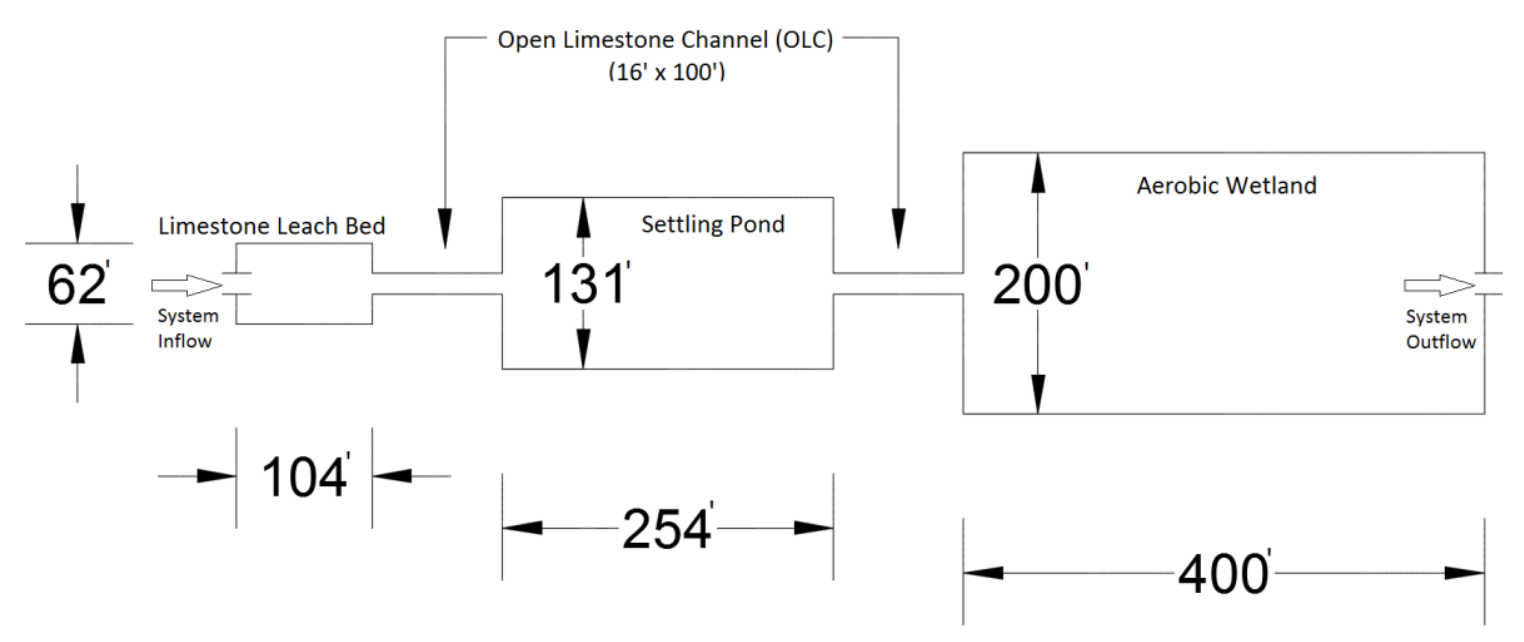

Figure 50: Conceptual sketch of the Middle Start remediation system.

\section{Trib 1 DS}

The final, optional, treatment location for Lick Runs remediation is at Trib 1 . This system would greatly increase the overall health of Lick Run, but would cost an additional $\$ 309,966$ because of high flow. Treating Trib 1 alone could greatly reduce the cost of this site's system without greatly affecting the overall remediation of Lick Run and requiring much less space for implementation. Trib 1 DS has an average $\mathrm{pH}$ of 3.65 with metal loads of about 46,080 lbs/yr of iron, 40,700 lbs/yr of aluminum, and 3,960 lbs/yr of manganese at a flow rate of about 1,417.5 gpm, rendering a design flow of about 1,560 gpm. With these parameters, AMD Treat generated cell sizes of (200 $\mathrm{ft}$. $x 110 \mathrm{ft}$.) for the limestone leach bed, (465 ft. x $236 \mathrm{ft}$.) for the settling pond, and a (420 ft. $x$ $210 \mathrm{ft}$.) aerobic wetland with a retention time of 3 hours. This wetlands area represents $34 \%$ of that which is suggested by AMD Treat when designed by metal removal rates; treating this tributary alone would greatly increase the feasibility of designing by metal removal rates. The implementation of the general treatment system, with these cell dimensions, would create effluents of 9,246 lbs/day of iron, 8,140 lbs/yr of aluminum, and $792 \mathrm{lbs} / \mathrm{yr}$ of manganese; $\mathrm{pH}$ would increase to a minimum of at least 6 . A conceptual sketch of this system is shown in Figure 51. 


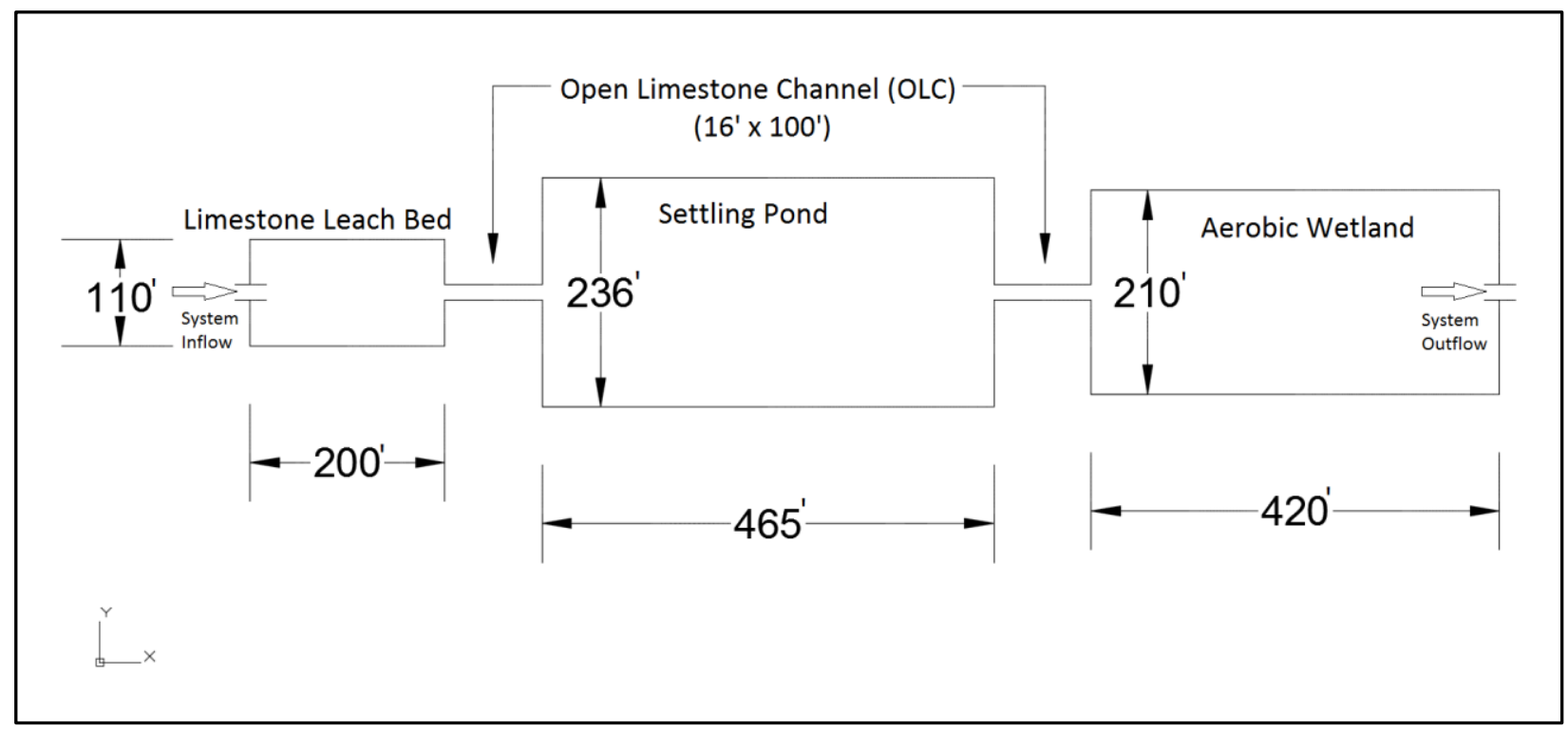

Figure 51: Conceptual sketch of the Trib 1 DS remediation system.

As said before, the dimensions and design considerations acknowledged by this treatment strategy are general estimates used for analyzing the feasibility of passive treatment within Lick Run. Data used for this report was originally taken for use in the Watershed Based Plan for Lick Run of the Cheat River (HUC-12 \#050200040702). This treatment strategy was developed using researched and modeled estimates and are as accurate as technology and the scopes of this project would allow. Should Lick Run receive implementation of a comprehensive treatment plan, all other variables and exact design considerations are left to the administering engineering company under the guidance of the Watershed Based Plan for Lick Run of the Cheat River (HUC$12 \# 050200040702$ ), created by the WVWRI, in support of the FOC, for the WVDEP. 


\section{Conclusions}

In conclusion, the remediation of Lick Run to $80 \%$ reduction of metal loads is feasible, but would incur an extremely high capital cost; the implementation of the suggested passive treatment systems would cost an estimated $\$ 2,093,814$. After installation, however, the systems will require very little maintenance, thus cost little to operate over their engineered lifespans of 20 years. The other positive outcome of the suggested treatment strategy is the fact that it is based around wetland modules, therefore, the natural identity of the Lick Run watershed will not be entirely lost.

Water quality standards for Lick Run were determined to be $0.75 \mathrm{mg} / \mathrm{l}$ of Al, $1.5 \mathrm{mg} / \mathrm{l}$ of Fe, 1.0 $\mathrm{mg} / \mathrm{l}$ of $\mathrm{Mn}$, with $\mathrm{pH}$ between 6 and 9 . These standards meet wetland and human health requirements but do not meet trout water and warm water fishery standards. Because all of these standards will be so difficult to reach in the foreseeable future, the more practical set of standards is addressed by the WVWRI first; thus the standards for Lick Run are currently applied in respect to wetlands and human health.

Because Lick Run is rural, it increases the chance of implementation based on land requirements. The systems proposed demand large plots of land for their modules to be effective. Since so much of the watershed is undeveloped, it would be easier to receive access to lands for these large scale treatment systems. Also, the fact that Friends of the Cheat (FOC) owns a parcel of land at the Bottom Fork further increases the chances to meet land requirements at this location, which is the most important location that entails the most amount of space for adequate treatment.

The remediation of Lick Run to $100 \%$ reduction of metal loads is not feasible. Not only does land requirements strongly hinder the ability to implement such systems that could accommodate any reduction close to these levels, but the reduction of all metals from AMD has been confirmed to be very difficult. The West Virginia Water Research Institute (WVWRI), follows a standard to treat AMD to $80 \%$ because it becomes exponentially tougher to remove metals past this mark.

In the end, treating Lick Run is necessary due to its extremely high metal loads. Section 5.2.2 shows how much Lick Runs small flow affects the wide constraints of the Cheat River by decreasing $\mathrm{pH}$ by one to two levels. It also shows how metal load concentrations are increased significantly after the input from Lick Run. If nothing else, a more comprehensive study of Lick Run's hydrology should be performed in order to have more accurate results for better treatment analysis. In particular, Trib 1 should be further tested to better see the extent of AMD contribution that it conveys. Treating Trib 1 before it flows into the mainstem could decrease capital costs to be below $\$ 2,000,000$ without affecting total treatment outcomes. 


\section{References}

Barbour, M.T., Gerritsen, J., Snyder, B.D., Stribling, J.B. (1999). "Rapid Bioassessment Protocols for Use in Streams and Wadeable Rivers: Periphyton, Benthic Macroinvertebrates, and Fish Second Edition." EPA 841-B-99-002. US Environmental Protection Agency Office of Water, Washington, D.C.

Chang, N. (2011). "Water Quality Management." Systems Analysis for Sustainable Engineering: Theory and Applications (Green Manufacturing \& Systems Engineering). McGraw-Hill Professional, Chicago, IL.

Cohen, R. R. H. (2006). "Use of microbes for cost reduction of metal removal from metals and mining industry waste streams." Journal of Cleaner Production, 14(12-13), 1146-1157.

Corbitt, R. A. (1999). "Wetland Treatment Systems." Standard Handbook of Environmental Engineering, Second Edition. McGraw-Hill Professional, Chicago, IL.

Cravotta III, C. A. (2010). "Abandoned Mine Drainage in the Swatara Creek Basin, Southern Anthracite Coalfield, Pennsylvania, USA: 2. Performance of Treatment Systems." Mine Water and the Environment, 29(3), 200-216.

Davis, M. L. (2010). "General Wastewater Treatment and Design Considerations." Water and Wastewater Engineering: Design Principles and Practice. McGraw-Hill Professional, Chicago, IL.

Gerritsen, J., Burton, J., Barbour, M.T. (2000). "A Stream Condition Index For West Virginia Wadeable Streams." EPA. Tetra Tech, Inc., Owings Mills, MD.

Johnson, D. B., Hallberg, K. B. (2005). "Acid mine drainage remediation options: a review." Science of the Total Environment, 338(1-2), 3-14.

Landmark Geospatial. (2014). "Preston County Parcel Search." Parcel Search, <http://www.landmarkgeospatial.com/preston/> (Aug. 15, 2014).

Lee, J. Y., Khim, J., Woo, K., Ji, W. H. (2013). "A Full-Scale Successive Alkalinity-Producing Passive System (SAPPS) for the Treatment of Acid Mine Drainage." Water Air and Soil Pollution, 224(9), 1-8.

MHS\&T. (2014a). "1990 Coal Production and Employment By County." West Virginia Mining Statistics 1996-2012, <http://www.wvminesafety.org/PDFs/1990prodempl.pdf> (Oct. 8, 2014). 
MHS\&T. (2014b). "2012 Coal Production and Employment By County." West Virginia Mining Statistics 1996-2012, <http://www.wvminesafety.org/2012\%20Annual/2012prodempl.pdf> (Oct. 8, 2014).

Nag, A. (2010a). "Geographic Information System-Based Watershed Modeling Systems." Biosystems Engineering. McGraw-Hill Professional, Chicago, IL.

Nag, A. (2010b). "Soil and Water Conservation." Biosystems Engineering. McGraw-Hill Professional, Chicago, IL.

National Oceanic and Atmospheric Administration (NOAA). (2010). “Data Tools: 1981-2010 Normals." Climate Data Online, <http://www.ncdc.noaa.gov/cdo-web/datatools/normals> (June 24, 2014).

Office of Surface Mining Reclamations and Enforcement (OSMRE). (2014a). "e-AMLIS Abandoned Mine Land Inventory System." Office of Surface Mining, <http://amlis.osmre.gov/> (June 24, 2014).

OSMRE. (2014b). "Surface Mining Control and Reclamation Act (SMCRA)." Laws, Regulations, and Guidance, <http://www.osmre.gov/Irg.shtm> (Aug. 14, 2014).

OSMRE. (2014c). "What is AMD Treat?." AMD Treat. <http://amd.osmre.gov/> (Aug. 27, 2014).

Patton, B. J., Beverage, W. W., Pohlman, G. G. (1959). "Soil Survey of Preston County, West Virginia." United States Department of Agriculture. US Government Printing Office, Washington 25, DC.

Sheoran, A.S., Sheoran, V. (2006). "Heavy metal removal mechanism of acid mine drainage in wetlands: A critical review." Minerals Engineering, 19(2), 105-116.

Skousen, J.G., Sexstone A.J., Ziemkiewicz, P. F. (2000). "Acid mine drainage control and treatment." Reclamation of Drastically Disturbed Lands. American Society of Agronomy and American Society for Surface Mining and Reclamation, Madison, WI, 131-168.

Skousen, J., Larew, G. (1992). “Alkaline Addition to Prevent Acid Mine Drainage: a field example.” Green Lands, 22(3), 32-35.

Tetra Tech. (2011). "Final USEPA Approved Report Total Maximum Daily Loads for Selected Streams in the Cheat River Watershed, West Virginia." WVDEP. Tetra Tech, Inc., Charleston, WV.

United States Environmental Protection Agency (USEPA). (2002). "The Twenty Needs Report: How Research Can Improve the TMDL Program." EPA 841-B-02-002. US Environmental Protection Agency Office of Water, Washington, DC. 
United States Geologic Survey (USGS). (2000a). "Collecting Water-Quality Samples." Interagency Field Manual for the Collection of Water-Quality Data. 00-213. USGS, Austin, TX.

USDA National Agricultural Statistics Service (USDA NASS). (2012). "Table 1. County Summary Highlights: 2012." 2012 Census of Agriculture - County Data, <http://www.agcensus.usda.gov/Publications/2012/Full_Report/Volume_1,_Chapter_2_Count Y_Level/West_Virginia/st54_2_001_001.pdf> (July 24, 2014).

USDA Natural Resources Conservation Service (USDA NRCS). (2013). "Web Soil Survey." Web Soil Survey Home, <http://websoilsurvey.sc.egov.usda.gov/App/WebSoilSurvey.aspx> (Aug. 2, 2014).

USDA NRCS. (2005). "Land Reclamation Toxic Discharge Control." Conservation Practice Standard Code 455, <http://www.nrcs.usda.gov/Internet/FSE_DOCUMENTS/nrcs143_026075.pdf> (Nov. 9, 2014).

USEPA. (2004). "Evaluation of Impacts to Underground Sources of Drinking Water by Hydraulic Fracturing of Coalbed Methane Reservoirs Study (2004)." EPA 816-R-04-003. US Environmental Protection Agency Office of Water, Washington, DC.

USEPA. (2012a). "Clean Water Act Section 101 (a)." Laws and Regulations, <http://water.epa.gov/lawsregs/guidance/101a.cfm> (Oct. 4, 2014).

USEPA. (2012b). "Clean Water Act Section 303." Laws and Regulations, <http://water.epa.gov/lawsregs/guidance/303.cfm> (Oct. 4, 2014).

USEPA. (2012c). "Overview of Impaired Waters and Total Maximum Daily Loads Program." Laws and Regulations, <http://water.epa.gov/lawsregs/lawsguidance/cwa/tmdl/intro.cfm> (Oct. 4, 2014).

USGS. (2000b). "Executive Summary." Coal Resource Assessment of Selected Coal Beds and Zones in the Northern and Central Appalachian Basin Coal Regions. 1625-C. US Department of the Interior, Reston, VA.

USGS. (2013). "Appalachian Basin Coal Assessment." Energy Resources Program, <http://energy.usgs.gov/Coal/AssessmentsandData/CoalAssessments/AppalachianBasinCoalAss essment.aspx\#377417-assessment-data> (Aug. 8, 2014).

USGS. (2014a). "Feature Detail Report for: Howesville Post Office (historical.” Geographic Names Information System (GNIS), <http://geonames.usgs.gov/apex/f?p=gnispq:3:0::NO::P3_FID:1558560> (Aug. 21, 2014).

USGS. (2014b). "How Streamflow is Measured Part 2: The discharge measurement." Surface Water Information, <http://water.usgs.gov/edu/streamflow2.html> (Oct. 17). 
USGS. (2014c). "Land Cover Analysis Tool." National Gap Analysis Program (GAP), <http://gis1.usgs.gov/csas/gap/viewer/land_cover/Map.aspx> (July 15, 2014).

Water Environment Federation (WEF). (2011). "Regulations of Nutrients in the Effluents of Wastewater Treatment Plants." Nutrient Removal. McGraw-Hill Professional, Chicago, IL.

West Virginia Department of Environmental Protection (WVDEP). (2008). "Series 5, Antidegradation Implementation Procedures." Title 60 Legislative Rule, <http://apps.sos.wv.gov/adlaw/csr/readfile.aspx?Docld=7095\&Format=PDF> (Aug. 12, 2014).

West Virginia Geographic Information Systems Technical Center (WVGISTC). (2014). "WV State GIS Data Clearinghouse." GIS Data, <http://wvgis.wvu.edu/data/data.php> (July 18, 2014).

West Virginia Geological and Economic Survey (WVGES). (2012). "West Virginia Mine Pool Atlas." West Virginia Geological Survey. WVDEP, Charleston WV.

West Virginia Office of Miners' Health, Safety and Training (MHS\&T). (2012). "West Virginia Coal Mining Facts." West Virginia Coal Mining Facts, <http://www.wvminesafety.org/wvcoalfacts.htm> (Oct. 8, 2014).

WVDEP Technical Applications and GIS Unit (WVDEP TAGIS). (2014). "Mining Data Explorer." Applications, <http://tagis.dep.wv.gov/mining/> (July 31, 2014).

WVDEP. (2012). "Level-One Standard Operating Procedures Manual." West Virginia Save Our Streams Program, <http://www.dep.wv.gov/WWE/getinvolved/sos/Documents/SOPs/LevelOneSOPs.pdf> (Oct. 21, 2014).

WVDEP. (2014a). "Series 2, Requirements Governing Water Quality Standards." Title 47 Legislative Rule, <http://www.dep.wv.gov/WWE/Programs/wqs/Documents/Rule\%20Approved\%20Letter\%20a nd\%20Rule\%20Itself\%202014/WVDEP_WQS_2014Tri-

Review_FinalRule47CSR2_June_2014.pdf> (Aug. 12, 2014).

WVDEP. (2014b). "Watershed Plans." Water and Waste Management, <http://www.dep.wv.gov/WWE/Programs/nonptsource/WBP/Pages/WBPs.aspx> (Oct. 4, 2014).

WVDEP. (2014c). "Water Quality Standards." Water and Waste Management, <http://www.dep.wv.gov/WWE/Programs/wqs/Pages/default.aspx> (Aug. 12, 2014) 


\section{Appendices}

\subsection{Appendix A: Water Quality Data}

Table 11: Mine site sampling points.

\begin{tabular}{|c|c|c|c|c|c|c|c|}
\hline \multirow{2}{*}{ Source } & \multirow{2}{*}{ AMLIS \# } & \multicolumn{3}{|c|}{ Lattitude } & \multicolumn{3}{|c|}{ Longitude } \\
\hline & & DDD MM SS & DDD MM.MMM & DDD.DDDD & DDD MM SS & DDD MM.MMM & DDD.DDDD \\
\hline Lick Run \#4 P1 & \multirow{3}{*}{ WV001820 } & $39^{\circ} 25^{\prime} 32^{\prime \prime} \mathrm{N}$ & $39^{\circ} 25.549^{\prime} \mathrm{N}$ & 39.425817 & $79^{\circ} 42^{\prime} 17^{\prime \prime} \mathrm{W}$ & $79^{\circ} 42.285^{\prime} \mathrm{W}$ & -79.70475 \\
\hline Lick Run \#4 P2 & & $39^{\circ} 25^{\prime} 34^{\prime \prime} \mathrm{N}$ & $39^{\circ} 25.567^{\prime} \mathrm{N}$ & 39.426117 & $79^{\circ} 42^{\prime} 19^{\prime \prime} \mathrm{W}$ & $79^{\circ} 42.331^{\prime} \mathrm{W}$ & -79.705517 \\
\hline Lick Run \#4 P3 & & $39^{\circ} 25^{\prime} 34^{\prime \prime} \mathrm{N}$ & $39^{\circ} 25.567^{\prime} \mathrm{N}$ & 39.426111 & $79^{\circ} 42^{\prime} 21^{\prime \prime} \mathrm{W}$ & $79^{\circ} 42.350^{\prime} \mathrm{W}$ & -79.705833 \\
\hline Lick Run \#2 & WV001822 & $39^{\circ} 25^{\prime} 19^{\prime \prime} \mathrm{N}$ & $39^{\circ} 25.320^{\prime} \mathrm{N}$ & 39.422 & $79^{\circ} 43^{\prime} 33^{\prime \prime} \mathrm{W}$ & $79^{\circ} 43.552^{\prime} \mathrm{W}$ & -79.725867 \\
\hline Howesville Site 1 & WV001548 & $39^{\circ} 25^{\prime} 50^{\prime \prime} \mathrm{N}$ & $39^{\circ} 25.834^{\prime} \mathrm{N}$ & 39.430567 & $79^{\circ} 45^{\prime} 28^{\prime \prime} \mathrm{W}$ & $79^{\circ} 45.483^{\prime} \mathrm{W}$ & -79.75805 \\
\hline Howesville Site 2 & WV006422 & $39^{\circ} 26^{\prime} 40^{\prime \prime} \mathrm{N}$ & $39^{\circ} 26.674^{\prime} \mathrm{N}$ & 39.444567 & $79^{\circ} 45^{\prime} 20^{\prime \prime} \mathrm{W}$ & $79^{\circ} 45.336^{\prime} \mathrm{W}$ & -79.7556 \\
\hline
\end{tabular}


Table 12: In-stream sampling points.

\begin{tabular}{|c|c|c|c|c|c|c|c|}
\hline \multirow{2}{*}{ Source } & \multirow{2}{*}{ Location } & \multicolumn{3}{|c|}{ Lattitude } & \multicolumn{3}{|c|}{ Longitude } \\
\hline & & DDD MM SS & DDD MM.MMM & DDD.DDDD & DDD MM SS & DDD MM.MMM & DDD.DDDD \\
\hline Nothern Start & - & $39^{\circ} 26^{\prime} 25^{\prime \prime} \mathrm{N}$ & $x$ & $x$ & $79^{\circ} 44^{\prime} 48^{\prime \prime W}$ & $x$ & $x$ \\
\hline Southern Start & - & $39^{\circ} 25^{\prime} 49^{\prime \prime} \mathrm{N}$ & $x$ & $x$ & $79^{\circ} 45^{\prime} 30^{\prime \prime W}$ & $x$ & $x$ \\
\hline Middle Start & - & $39^{\circ} 26^{\prime} 05^{\prime \prime} \mathrm{N}$ & $x$ & $x$ & $79^{\circ} 43^{\prime} 53^{\prime \prime} W$ & $x$ & $x$ \\
\hline \multirow{3}{*}{ Top Fork } & North & $39^{\circ} 25^{\prime} 40^{\prime \prime} \mathrm{N}$ & $39^{\circ} 25.667^{\prime} \mathrm{N}$ & 39.427778 & $79^{\circ} 44^{\prime} 24^{\prime \prime W}$ & $79^{\circ} 44.400^{\prime} \mathrm{W}$ & -79.74 \\
\hline & South & $39^{\circ} 25^{\prime} 39^{\prime \prime} \mathrm{N}$ & $x$ & $x$ & $79^{\circ} 44^{\prime} 25^{\prime \prime W}$ & $x$ & $x$ \\
\hline & DS & $39^{\circ} 25^{\prime} 38^{\prime \prime} \mathrm{N}$ & $x$ & $x$ & $79^{\circ} 44^{\prime} 23^{\prime \prime W}$ & $x$ & $x$ \\
\hline \multirow{3}{*}{ Trib 1} & Mouth & $x$ & $x$ & $x$ & $x$ & $x$ & $x$ \\
\hline & US & $x$ & $x$ & $x$ & $x$ & $x$ & $x$ \\
\hline & DS & $39^{\circ} 25^{\prime} 10^{\prime \prime} \mathrm{N}$ & $39^{\circ} 25.168^{\prime} \mathrm{N}$ & 39.419467 & $79^{\circ} 43^{\prime} 23^{\prime \prime W}$ & $79^{\circ} 43.384^{\prime} \mathrm{W}$ & -79.723067 \\
\hline \multirow{3}{*}{ Bottom Fork } & Middle & $39^{\circ} 25^{\prime} 54^{\prime \prime} \mathrm{N}$ & $39^{\circ} 25.900^{\prime} \mathrm{N}$ & 39.431667 & $79^{\circ} 42^{\prime} 56^{\prime \prime W}$ & $79^{\circ} 42.933^{\prime} \mathrm{W}$ & -79.715556 \\
\hline & US & $39^{\circ} 25^{\prime} 23^{\prime \prime} \mathrm{N}$ & $39^{\circ} 25.391^{\prime} \mathrm{N}$ & 39.423183 & $79^{\circ} 42^{\prime} 32^{\prime \prime W}$ & $79^{\circ} 42.543^{\prime} \mathrm{W}$ & -79.70905 \\
\hline & DS & $39^{\circ} 25^{\prime} 33^{\prime \prime} \mathrm{N}$ & $x$ & $x$ & $79^{\circ} 42^{\prime} 18^{\prime \prime W}$ & $x$ & $x$ \\
\hline \multirow{3}{*}{ Discharge } & Mouth & $39^{\circ} 25^{\prime} 26^{\prime \prime} \mathrm{N}$ & $39^{\circ} 25.437^{\prime} \mathrm{N}$ & 39.42395 & $79^{\circ} 41^{\prime} 18^{\prime \prime W}$ & $79^{\circ} 41.314^{\prime} \mathrm{W}$ & -79.688567 \\
\hline & US & $39^{\circ} 25^{\prime} 33^{\prime \prime} \mathrm{N}$ & $39^{\circ} 25.551^{\prime} \mathrm{N}$ & 39.42585 & $79^{\circ} 41^{\prime} 08^{\prime \prime W}$ & $79^{\circ} 41.143^{\prime} \mathrm{W}$ & -79.685717 \\
\hline & DS & $39^{\circ} 25^{\prime} 38^{\prime \prime} \mathrm{N}$ & $39^{\circ} 25.639^{\prime} \mathrm{N}$ & 39.427317 & $79^{\circ} 41^{\prime} 14^{\prime \prime W}$ & $79^{\circ} 41.241^{\prime} \mathrm{W}$ & -79.68735 \\
\hline
\end{tabular}


WV329 (Lick Run) Mine-Site Sampling Results

Sample Set 1

Increment 1

\begin{tabular}{|c|c|c|c|c|c|c|c|c|c|c|c|c|}
\hline Date & Site & AMLIS \# & $\operatorname{Temp}\left({ }^{\circ} \mathrm{C}\right)$ & Conductivity $(\mu S / \mathrm{cm})$ & $T D S(m g / l)$ & $D O(m g / l)$ & $\mathrm{PH}$ & Flow (gal/min) & Total Width (ft) & Width (ft) & Depth $(\mathrm{ft})$ & Velocity (ft/s) \\
\hline \multirow{4}{*}{$8 / 15 / 2013$} & Lick Run \#4 P1 & \multirow{3}{*}{ WV1820 } & - & 1078 & - & - & 3.71 & 772.44 & 5 & 0.5 & 0.15 & 0.18 \\
\hline & Lick Run \#4 P2 & & 12.83 & 2179 & 1846 & 11.22 & 3.86 & 1425.94 & 12 & 1 & 0.15 & 0.84 \\
\hline & Lick Run \#4 P3 & & - & - & - & - & - & 0.00 & & & & \\
\hline & Lick Run \#2 & WV1822 & 18.7 & 1181 & 872 & 9.04 & 4 & 4.71 & 1.5 & 0.125 & 0.3 & 0 \\
\hline \multirow{2}{*}{$8 / 27 / 2013$} & Howesville Site 1 & WV1548 & 15.63 & 351 & 278 & 10.26 & 3.12 & 63.51 & 2 & 0.25 & 0.2 & 0.03 \\
\hline & Howesville Greaser & WV6422 & 15.92 & 1538 & 1210 & 9.14 & 2.41 & 95.26 & 2 & 0.25 & 0.1 & 0.07 \\
\hline
\end{tabular}

Sample Set 2

Increment 1

\begin{tabular}{|c|c|c|c|c|c|c|c|c|c|c|c|c|}
\hline Date & Site & AMLIS \# & $\operatorname{Temp}\left({ }^{\circ} \mathrm{C}\right)$ & Conductivity $(\mu \mathrm{S} / \mathrm{cm})$ & $T D S(m g / l)$ & $D O(m g / l)$ & $\mathrm{PH}$ & Flow (gal/min) & Total Width $(\mathrm{ft})$ & Width $(\mathrm{ft})$ & Depth (ft) & Velocity (ft/s) \\
\hline \multirow{5}{*}{$10 / 15 / 2013$} & Lick Run \#4 P1 & \multirow{3}{*}{ WV1820 } & 11.66 & 1430 & 1248 & 7.78 & 2.53 & 210.95 & \multicolumn{4}{|c|}{ <---- Flow data taken with Sondtech Flowtracker. } \\
\hline & Lick Run \#4 P2 & & 12.63 & 2300 & 1958 & 10.34 & 2.42 & 228.90 & \multicolumn{4}{|c|}{ <--- Flow data taken with Sondtech Flowtracker. } \\
\hline & Lick Run \#4 P3 & & 13.41 & 1327 & 1116 & 8.22 & 2.96 & 67.32 & \multicolumn{4}{|c|}{ <---- Flow data taken with Sondtech Flowtracker. } \\
\hline & Howesville Site 1 & WV1548 & 14.14 & 306 & 251 & 8.09 & 6.49 & 4.49 & \multicolumn{4}{|c|}{ <---- Flow data taken with Sondtech Flowtracker. } \\
\hline & Howesville Greaser & WV6422 & 15.12 & 2148 & 1721 & 8.53 & 2.49 & 8.98 & \multicolumn{4}{|c|}{ <---- Flow data taken with Sondtech Flowtracker. } \\
\hline $12 / 2 / 2013$ & Lick Run \#2 & WV1822 & 6.07 & 826 & 841 & 12.81 & 3.28 & 7.63 & 1 & 0.5 & 0.2 & 0.1 \\
\hline
\end{tabular}

\begin{tabular}{|c|c|c|c|c|c|c|c|c|c|c|c|c|}
\hline Date & Site & AMLIS \# & $\operatorname{Temp}\left({ }^{\circ} \mathrm{C}\right)$ & Conductivity $(\mu \mathrm{S} / \mathrm{cm})$ & $T D S(m g / l)$ & $D O(m g / l)$ & $\mathrm{PH}$ & Flow (gal/min) & Total Width $(\mathrm{ft})$ & Width (ft) & Depth (ft) & Velocity (ft/s) \\
\hline \multirow{5}{*}{$3 / 10 / 2014$} & Lick Run \#4 P1 & \multirow{3}{*}{ WV1820 } & 10.81 & 1334 & 1190 & 7.88 & 2.33 & 610.19 & 3.5 & 0.25 & 0.4 & 0.67 \\
\hline & Lick Run \#4 P2 & & 12.38 & 2123 & 1819 & 8.35 & 2.3 & 536.13 & $2+3$ & 0.5 & 0.2 & 0.45 \\
\hline & Lick Run \#4 P3 & & 4.3 & 433 & 465 & 12.56 & 2.91 & 1432.44 & 3 & 0.5 & 0.25 & 2.71 \\
\hline & Howesville Site 1 & WV1548 & 10.14 & 235 & 213 & 10.62 & 3.98 & 203.10 & 3 & 0.5 & 0.1 & 0 \\
\hline & Lick Run \#2 & WV1822 & 11.34 & 1306 & 1149 & 10.37 & 2.46 & 8.53 & 1 & 0.25 & 0.2 & 0 \\
\hline $3 / 11 / 2014$ & Howesville Greaser & WV6422 & 6.49 & 885 & 890 & 11.77 & 2.59 & 57.45 & 3 & 0.5 & 0.2 & 0.02 \\
\hline \multicolumn{10}{|c|}{ Sample Set 4} & \multicolumn{3}{|c|}{ Increment 1} \\
\hline Date & Site & AMLIS \# & $\operatorname{Temp}\left({ }^{\circ} \mathrm{C}\right)$ & Conductivity $(\mu \mathrm{S} / \mathrm{cm})$ & $T D S(m g / l)$ & $D O(m g / l)$ & $\mathrm{PH}$ & Flow (gal/min) & Total Width (ft) & Width (ft) & Depth (ft) & Velocity (ft/s) \\
\hline $5 / 12 / 2014$ & Lick Run \#2 & WV1822 & 22.41 & 1828 & 1250 & 13.23 & 2.58 & 5.72 & 0.5 & 0.25 & 0.2 & 0.25 \\
\hline \multirow{3}{*}{$5 / 21 / 2014$} & Lick Run \#4 P1 & \multirow{3}{*}{ WV1820 } & 10.89 & 1240 & 1103 & 2.76 & 2.21 & 410.23 & 3.5 & 0.25 & 0.4 & 1.6 \\
\hline & Lick Run \#4 P2 & & 12.65 & 2146 & 1826 & 9.56 & 2.57 & 550.49 & $1.5+3.5$ & 0.25 & 0.2 & 1.28 \\
\hline & Lick Run \#4 P3 & & 14.44 & 663 & 541 & 1.98 & 3.12 & 771.77 & 4 & 0.5 & 0.2 & 0.26 \\
\hline \multirow{2}{*}{$5 / 27 / 2014$} & Howesville Site 1 & WV1548 & 14.85 & 319 & 257 & 8.74 & 2.8 & 27.94 & 2.5 & 0.25 & 0.15 & 0.1 \\
\hline & Howesville Greaser & WV6422 & 15.75 & 1376 & 1087 & 9 & 2.38 & 34.11 & 2 & 0.5 & 0.1 & 0.1 \\
\hline
\end{tabular}


Table 13 (Continued): Raw mine site sampling results (flow data).

\begin{tabular}{|c|c|c|c|c|c|c|c|c|c|c|c|c|c|c|c|c|c|c|c|c|c|c|c|}
\hline \multicolumn{3}{|c|}{ Increment 2} & \multicolumn{3}{|c|}{ Increment 3} & \multicolumn{3}{|c|}{ Increment 4} & \multicolumn{3}{|c|}{ Increment 5} & \multicolumn{3}{|c|}{ Increment 6} & \multicolumn{3}{|c|}{ Increment 7} & \multicolumn{3}{|c|}{ Increment 8} & \multicolumn{3}{|c|}{ Increment 9} \\
\hline$W(\mathrm{ft})$ & $D(\mathrm{ft})$ & $V(\mathrm{ft} / \mathrm{s})$ & $W(\mathrm{ft})$ & $D(\mathrm{ft})$ & $V(\mathrm{ft} / \mathrm{s})$ & $W(\mathrm{ft})$ & $D(\mathrm{ft})$ & $V(\mathrm{ft} / \mathrm{s})$ & $W(\mathrm{ft})$ & $D(\mathrm{ft})$ & $V(\mathrm{ft} / \mathrm{s})$ & $W(\mathrm{ft})$ & $D(\mathrm{ft})$ & $V(\mathrm{ft} / \mathrm{s})$ & $W(\mathrm{ft})$ & $D(\mathrm{ft})$ & $V(\mathrm{ft} / \mathrm{s})$ & $W(\mathrm{ft})$ & $D(\mathrm{ft})$ & $V(\mathrm{ft} / \mathrm{s})$ & $W(\mathrm{ft})$ & $D(\mathrm{ft})$ & $V(\mathrm{ft} / \mathrm{s})$ \\
\hline 1 & 0.4 & 0.24 & 1 & 0.55 & 1.44 & 1 & 0.45 & 1.26 & 1 & 0.25 & 1.01 & 0.5 & 0.3 & 0 & & & & & & & & & \\
\hline 2 & 0.1 & 1.47 & 2 & 0.2 & 0.6 & 2 & 0.1 & 3.14 & 2 & 0.1 & 4.4 & 2 & 0.2 & 2.17 & 1 & 0.1 & 1.41 & & & & & & \\
\hline & & & & & & & & & & & & & & & & & & & & & & & \\
\hline$\frac{0.25}{0.5}$ & $\frac{0.3}{0.3}$ & $\frac{0.01}{0.13}$ & $\frac{0.25}{0.5}$ & $\frac{0.3}{0.3}$ & 0.05 & 0.25 & 0.3 & 0.04 & 0.25 & 0.3 & 0.02 & 0.25 & 0.3 & 0.02 & 0.125 & 0.15 & 0 & & & & & & \\
\hline $\begin{array}{l}0.5 \\
0.5\end{array}$ & $\begin{array}{l}0.3 \\
0.2\end{array}$ & $\begin{array}{l}0.13 \\
0.02\end{array}$ & $\begin{array}{l}0.5 \\
0.5\end{array}$ & $\begin{array}{l}0.3 \\
0.25\end{array}$ & $\begin{array}{l}0.48 \\
0.64\end{array}$ & $\begin{array}{l}0.5 \\
0.5\end{array}$ & $\begin{array}{l}0.2 \\
0.2\end{array}$ & $\begin{array}{l}0.4 / \\
1.13\end{array}$ & $\begin{array}{l}0.25 \\
0.25\end{array}$ & $\begin{array}{l}0.1 \\
0.2\end{array}$ & $\begin{array}{l}0.06 \\
0.31\end{array}$ & & & & & & & & & & & & \\
\hline
\end{tabular}

\begin{tabular}{|c|c|c|c|c|c|c|c|c|c|c|c|c|c|c|c|c|c|c|c|c|c|c|c|}
\hline \multicolumn{3}{|c|}{ Increment 2} & \multicolumn{3}{|c|}{ Increment 3} & \multicolumn{3}{|c|}{ Increment 4} & \multicolumn{3}{|c|}{ Increment 5} & \multicolumn{3}{|c|}{ Increment 6} & \multicolumn{3}{|c|}{ Increment 7} & \multicolumn{3}{|c|}{ Increment 8} & \multicolumn{3}{|c|}{ Increment 9} \\
\hline$W(\mathrm{ft})$ & $D(\mathrm{ft})$ & $V(\mathrm{ft} / \mathrm{s})$ & $\mathrm{W}(\mathrm{ft})$ & $D(\mathrm{ft})$ & $V(\mathrm{ft} / \mathrm{s})$ & $\mathrm{W}(\mathrm{ft})$ & $D(\mathrm{ft})$ & $V(\mathrm{ft} / \mathrm{s})$ & $W(\mathrm{ft})$ & $D(\mathrm{ft})$ & $V(\mathrm{ft} / \mathrm{s})$ & $W(\mathrm{ft})$ & $D(\mathrm{ft})$ & $V(\mathrm{ft} / \mathrm{s})$ & W (ft) & $D(\mathrm{ft})$ & $V(\mathrm{ft} / \mathrm{s})$ & W (ft) & $D(\mathrm{ft})$ & $V(\mathrm{ft} / \mathrm{s})$ & $\mathrm{W}(\mathrm{ft})$ & $D(\mathrm{ft})$ & $V(\mathrm{ft} / \mathrm{s})$ \\
\hline & & & & & & & & & & & & & & & & & & & & & & & \\
\hline & & & & & & & & & & & & & & & & & & & & & & & \\
\hline & & & & & & & & & & & & & & & & & & & & & & & \\
\hline & & & & & & & & & & & & & & & & & & & & & & & \\
\hline & & & & & & & & & & & & & & & & & & & & & & & \\
\hline 0.5 & 0.2 & 0.07 & & & & & & & & & & & & & & & & & & & & & \\
\hline
\end{tabular}

\begin{tabular}{|c|c|c|c|c|c|c|c|c|c|c|c|c|c|c|c|c|c|c|c|c|c|c|c|}
\hline \multicolumn{3}{|c|}{ Increment 2} & \multicolumn{3}{|c|}{ Increment 3} & \multicolumn{3}{|c|}{ Increment 4} & \multicolumn{3}{|c|}{ Increment 5} & \multicolumn{3}{|c|}{ Increment 6} & \multicolumn{3}{|c|}{ Increment 7} & \multicolumn{3}{|c|}{ Increment 8} & \multicolumn{3}{|c|}{ Increment 9} \\
\hline$W(\mathrm{ft})$ & $D(\mathrm{ft})$ & $V(\mathrm{ft} / \mathrm{s})$ & $\mathrm{W}(\mathrm{ft})$ & $D(f t)$ & $V(\mathrm{ft} / \mathrm{s})$ & $\mathrm{W}(\mathrm{ft})$ & $D(\mathrm{ft})$ & $V(\mathrm{ft} / \mathrm{s})$ & $W(\mathrm{ft})$ & $D(\mathrm{ft})$ & $V(\mathrm{ft} / \mathrm{s})$ & $\mathrm{W}(\mathrm{ft})$ & $D(\mathrm{ft})$ & $V(\mathrm{ft} / \mathrm{s})$ & $W(\mathrm{ft})$ & $D(\mathrm{ft})$ & $V(\mathrm{ft} / \mathrm{s})$ & $W(\mathrm{ft})$ & $D(\mathrm{ft})$ & $V(\mathrm{ft} / \mathrm{s})$ & $W(\mathrm{ft})$ & $D(\mathrm{ft})$ & $V(\mathrm{ft} / \mathrm{s})$ \\
\hline 1 & 0.45 & 1.71 & 1 & 0.3 & 1.2 & $\overline{1}$ & 0.2 & 0.75 & 0.25 & 0.1 & 0.52 & & & & & & & & & & & & \\
\hline 1 & 0.2 & 0.55 & 0.5 & 0.15 & 0.35 & & & & 0.5 & 0.25 & 0.21 & 1 & 0.3 & 0.56 & 1 & 0.3 & 2.27 & 0.5 & 0.2 & 1.38 & & & \\
\hline 1 & 0.3 & 4.11 & 1 & 0.4 & 3.44 & 0.5 & 0.15 & 3.25 & & & & & & & & & & & & & & & \\
\hline 1 & 0.1 & 0.19 & 1 & 0.35 & 1.2 & 0.5 & 0.15 & 0.18 & & & & & & & & & & & & & & & \\
\hline 0.5 & 0.2 & 0.15 & 0.25 & 0.2 & 0.08 & & & & & & & & & & & & & & & & & & \\
\hline 1 & 0.3 & 0.16 & 1 & 0.3 & 0.22 & 0.5 & 0.2 & 0.12 & & & & & & & & & & & & & & & \\
\hline
\end{tabular}

\begin{tabular}{|c|c|c|c|c|c|c|c|c|c|c|c|c|c|c|c|c|c|c|c|c|c|c|c|}
\hline \multicolumn{3}{|c|}{ Increment 2} & \multicolumn{3}{|c|}{ Increment 3} & \multicolumn{3}{|c|}{ Increment 4} & \multicolumn{3}{|c|}{ Increment 5} & \multicolumn{3}{|c|}{ Increment 6} & \multicolumn{3}{|c|}{ Increment 7} & \multicolumn{3}{|c|}{ Increment 8} & \multicolumn{3}{|c|}{ Increment 9} \\
\hline$W(\mathrm{ft})$ & $D(\mathrm{ft})$ & $V(\mathrm{ft} / \mathrm{s})$ & $W(\mathrm{ft})$ & $D(\mathrm{ft})$ & $V(\mathrm{ft} / \mathrm{s})$ & $W(\mathrm{ft})$ & $D(\mathrm{ft})$ & $V(\mathrm{ft} / \mathrm{s})$ & $W(\mathrm{ft})$ & $D(\mathrm{ft})$ & $V(\mathrm{ft} / \mathrm{s})$ & $W(\mathrm{ft})$ & $D(\mathrm{ft})$ & $V(\mathrm{ft} / \mathrm{s})$ & $W(\mathrm{ft})$ & $D(\mathrm{ft})$ & $V(\mathrm{ft} / \mathrm{s})$ & $W(\mathrm{ft})$ & $D(\mathrm{ft})$ & $V(\mathrm{ft} / \mathrm{s})$ & $W(\mathrm{ft})$ & $D(\mathrm{ft})$ & $V(\mathrm{ft} / \mathrm{s})$ \\
\hline 0.25 & 0.1 & 0.01 & & & & & & & & & & & & & & & & & & & & & \\
\hline 1 & 0.3 & 1.5 & 1 & 0.3 & 0.98 & 1 & 0.2 & 0.05 & 0.25 & 0.1 & 0 & & & & & & & & & & & & \\
\hline 1 & 0.25 & 1.07 & 0.25 & 0.25 & 0.9 & & & & 0.25 & 0.3 & 1.47 & 1 & 0.35 & 1.28 & 1 & 0.25 & 0.64 & 1 & 0.2 & 0.48 & 0.25 & 0.2 & 0.49 \\
\hline 1 & 0.3 & 1.76 & 1 & 0.25 & 2.54 & 1 & 0.2 & 2.31 & 0.5 & 0.1 & 1.37 & & & & & & & & & & & & \\
\hline 1 & 0.2 & 0.09 & 1 & 0.2 & 0.17 & 0.25 & 0.2 & 0.13 & & & & & & & & & & & & & & & \\
\hline 1 & 0.2 & 0.35 & 0.5 & 0.2 & 0.01 & & & & & & & & & & & & & & & & & & \\
\hline
\end{tabular}


WV329 (Lick Run) In-Stream Sampling Results

Sample Set 1

Increment 1

\begin{tabular}{|c|c|c|c|c|c|c|c|c|c|c|c|c|}
\hline Date & Site & Location & $\operatorname{Temp}\left({ }^{\circ} \mathrm{C}\right)$ & Conductivity $(\mu \mathrm{S} / \mathrm{cm})$ & $T D S(m g / l)$ & $D O(m g / l)$ & $P H$ & Flow (gal/min) & Total Width $(\mathrm{ft})$ & Width (ft) & Depth (ft) & Velocity (ft/s) \\
\hline \multirow{7}{*}{$7 / 26 / 2013$} & \multirow{3}{*}{ Discharge } & Mouth & 15.31 & 890 & 710 & 10.74 & 3 & 2602.44 & 5 & 0.5 & 0.7 & 0 \\
\hline & & US & 19.94 & 60 & 43 & 8.82 & 5.83 & $\mathrm{~N} / \mathrm{A}$ & \multicolumn{3}{|c|}{ <--- Flow da ta not taken, large river. } & \\
\hline & & DS & 19.15 & 224 & 164 & 10.18 & 3.9 & $\mathrm{~N} / \mathrm{A}$ & \multicolumn{3}{|c|}{ <---- Flow data not taken, large river. } & \\
\hline & \multirow{2}{*}{ Bottom Fork } & Middle & - & - & - & - & - & $\mathrm{N} / \mathrm{A}$ & & & & \\
\hline & & US & 17.01 & 402 & 308 & 10.24 & 3.37 & 1751.00 & 2.5 & 0.25 & 0.6 & 3.05 \\
\hline & Trib 1 & DS & 17.65 & 772 & 584 & 10 & 3.19 & 131.11 & 2.5 & 0.25 & 0.25 & 0.49 \\
\hline & FopFork & North & 18.72 & 766 & 566 & 9.76 & 3.01 & 805.20 & 7 & 0.5 & $\theta .2$ & 0.63 \\
\hline \multicolumn{10}{|c|}{ Sample Set 2} & \multicolumn{3}{|c|}{ Increment 1} \\
\hline
\end{tabular}

\begin{tabular}{|c|c|c|c|c|c|c|c|c|c|c|c|}
\hline Date & Site & Location & $\operatorname{Temp}\left({ }^{\circ} \mathrm{C}\right)$ & Conductivity $(\mu S / \mathrm{cm})$ & $T D S(m g / l)$ & $D O(m g / l)$ & $\mathrm{PH}$ & Flow (gal/min) & Total Width $(\mathrm{ft})$ & Width (ft) Depth (ft) & Velocity $(\mathrm{ft} / \mathrm{s})$ \\
\hline \multirow{7}{*}{$10 / 8 / 2013$} & \multirow{3}{*}{ Discharge } & Mouth & 11.08 & 1316 & 1166 & 12.14 & 2.36 & 951.52 & \multicolumn{3}{|c|}{ <--- Flow data taken with Sondtech Flowtracker. } \\
\hline & & US & 17.75 & 95 & 72 & 9.8 & 7.26 & $N / A$ & \multicolumn{2}{|c|}{ <---- Flow data not taken, large river. } & \\
\hline & & DS & 17.32 & 186 & 142 & 10.27 & 4.56 & $\mathrm{~N} / \mathrm{A}$ & \multicolumn{2}{|c|}{ <---- Flow data not taken, large river. } & \\
\hline & Rottom Fork & Middle & 12.18 & 1013 & 872 & 9.73 & 2.8 & 188.51 & \multicolumn{3}{|c|}{ <--- Flow data taken with Sondtech Flowtracker. } \\
\hline & DOLIOMII rork & US & - & - & - & - & - & $\mathrm{N} / \mathrm{A}$ & & & \\
\hline & Trib 1 & DS & 14.35 & 530 & 433 & 9.21 & 3.12 & 264.81 & \multicolumn{3}{|c|}{ <---- Flow data taken with Sondtech Flowtracker. } \\
\hline & FopFork & North & 12.18 & 1013 & 872 & 9.73 & $z .8$ & 188.51 & \multicolumn{3}{|c|}{ L Flow data taken with Sondtech Flowtracker. } \\
\hline
\end{tabular}

Sample Set 3

Increment 1

\begin{tabular}{|c|c|c|c|c|c|c|c|c|c|c|c|c|}
\hline & & & & & & & & & & & & \\
\hline Date & Site & Location & $\operatorname{Temp}\left({ }^{\circ} \mathrm{C}\right)$ & Conductivity $(\mu \mathrm{S} / \mathrm{cm})$ & $T D S(m g / l)$ & $D O(m g / l)$ & $\mathrm{PH}$ & Flow (gal/min) & Total Width $(\mathrm{ft})$ & Width (ft) & Depth (ft) & Velocity (ft/s) \\
\hline & & Mouth & 3.89 & 491 & 534 & 13.51 & 1.64 & 5197.69 & 18 & 1 & 0.95 & 1.75 \\
\hline & Discharge & US & 4.32 & 43 & 46 & 13.06 & 4.86 & $N / A$ & <---- Flow data not $t$ & taken, large ri & iver. & \\
\hline $3 / 10 / 2014$ & & DS & 4.2 & 197 & 212 & 13.47 & 2.39 & $\mathrm{~N} / \mathrm{A}$ & $<---$ Flow data not $t$ & taken, large ri & iver. & \\
\hline & Trib 1 & DS & 6.41 & 242 & 244 & 11.97 & 3.11 & 2698.37 & 16 & 0.5 & 0.1 & 0.01 \\
\hline $3 / 12 / 2014$ & Bottom Fork & Middle & 5.71 & 317 & 326 & 12.46 & 2.84 & 515.37 & 4 & 0.5 & 0.2 & 0.23 \\
\hline & & & & Sample & $t 4$ & & & & & & Increr & \\
\hline
\end{tabular}

\begin{tabular}{|c|c|c|c|c|c|c|c|c|c|c|c|c|}
\hline & \multicolumn{3}{|c|}{ Increment 1} \\
\hline Date & Site & Location & $\operatorname{Temp}\left({ }^{\circ} \mathrm{C}\right)$ & Conductivity ( $\mu \mathrm{S} / \mathrm{cm})$ & $T D S(m g / l)$ & $D O(\mathrm{mg} / \mathrm{l})$ & $\mathrm{PH}$ & Flow (gal/min) & Total Width $(\mathrm{ft})$ & Width $(\mathrm{ft})$ & Depth (ft) & Velocity (ft/s) \\
\hline \multirow{5}{*}{$5 / 12 / 2014$} & \multirow{3}{*}{ Discharge } & Mouth & 14.2 & 1031 & 844 & 10.51 & 2.35 & 1969.92 & 15 & 1.5 & 0.6 & 0.52 \\
\hline & & US & 19.36 & 68 & 49 & 12.62 & 5.65 & $\mathrm{~N} / \mathrm{A}$ & \multicolumn{3}{|c|}{ <--- Flow data not taken, large river. } & \\
\hline & & DS & 17.76 & 481 & 361 & 13.97 & 3.01 & $\mathrm{~N} / \mathrm{A}$ & \multicolumn{3}{|c|}{ <---- Flow data not taken, large river. } & \\
\hline & Bottom Fork & Middle & 17.77 & 906 & 683 & 11.48 & 2.59 & 178.19 & 2.5 & 0.25 & 0.1 & 2.75 \\
\hline & Trib 1 & DS & 19.73 & 529 & 382 & 17.36 & 3.12 & 956.01 & 8 & 1 & 0.2 & 0.05 \\
\hline \multirow{2}{*}{$5 / 27 / 2014$} & \multirow{2}{*}{ Trib 1} & Mouth & 15.93 & 560 & 440 & 10.28 & 2.57 & 185.14 & 3 & 0.5 & 0.2 & 1.01 \\
\hline & & US & 16.76 & 435 & 336 & 10.39 & 2.75 & 770.87 & \multicolumn{4}{|c|}{ <---- Value estimated by subtracting Mouth from DS. } \\
\hline
\end{tabular}


Table 14 (Continued): Raw in-stream sampling results (flow data).

\begin{tabular}{|c|c|c|c|c|c|c|c|c|c|c|c|c|c|c|c|c|c|c|c|c|c|c|c|c|c|c|}
\hline \multicolumn{3}{|c|}{ Increment 2} & \multicolumn{3}{|c|}{ Increment 3} & \multicolumn{3}{|c|}{ Increment 4} & \multicolumn{3}{|c|}{ Increment 5} & \multicolumn{3}{|c|}{ Increment 6} & \multicolumn{3}{|c|}{ Increment 7} & \multicolumn{3}{|c|}{ Increment 8} & \multicolumn{3}{|c|}{ Increment 9} & \multicolumn{3}{|c|}{ Increment 10} \\
\hline$W(\mathrm{ft})$ & $D(\mathrm{ft})$ & $V(\mathrm{ft} / \mathrm{s})$ & $W(\mathrm{ft})$ & $\mathrm{D}(\mathrm{ft})$ & $V(\mathrm{ft} / \mathrm{s})$ & W (ft) & $D(\mathrm{ft})$ & $V(\mathrm{ft} / \mathrm{s})$ & W (ft) & $\mathrm{D}(\mathrm{ft})$ & $V(\mathrm{ft} / \mathrm{s})$ & $W(\mathrm{ft})$ & $D(\mathrm{ft})$ & $V(\mathrm{ft} / \mathrm{s})$ & $W(\mathrm{ft})$ & $\mathrm{D}(\mathrm{ft})$ & $V(\mathrm{ft} / \mathrm{s})$ & W (ft) & $D(\mathrm{ft})$ & $V(\mathrm{ft} / \mathrm{s})$ & W (ft) & $\mathrm{D}(\mathrm{ft})$ & $V(\mathrm{ft} / \mathrm{s})$ & W (ft) & $\mathrm{D}(\mathrm{ft})$ & $V(\mathrm{ft} / \mathrm{s})$ \\
\hline 1 & 1.3 & 1.45 & 1 & 1.4 & 1.09 & 1 & 1.4 & 0.96 & 1 & 1.3 & 0.54 & 0.5 & 1.05 & 0.65 & & & & & & & & & & & & \\
\hline & & & & & & & & & & & & & & & & & & & & & & & & & & \\
\hline & & & & & & & & & & & & & & & & & & & & & & & & & & \\
\hline & & & & & & & & & & & & & & & & & & & & & & & & & & \\
\hline 0.5 & 0.6 & 3.85 & 0.5 & 0.5 & 3.63 & 0.5 & 0.4 & 3.63 & 0.5 & 0.35 & 3.17 & 0.25 & 0.2 & 2.01 & & & & & & & & & & & & \\
\hline 0.5 & 0.45 & 0.26 & 0.5 & 0.6 & 0.42 & 0.5 & 0.1 & 0.88 & 0.5 & 0.1 & 0.34 & 0.25 & 0.2 & 0.32 & & & & & & & & & & & & \\
\hline 1 & $\theta .3$ & 1.13 & 1 & $\theta .4$ & 1.27 & 1 & $\theta .3$ & 1.42 & 1 & $\theta .3$ & 0.97 & 7 & $\theta .2$ & 0.72 & 1 & $\theta .1$ & 0.23 & 0.5 & $\theta .1$ & $\theta$ & & & & & & \\
\hline
\end{tabular}

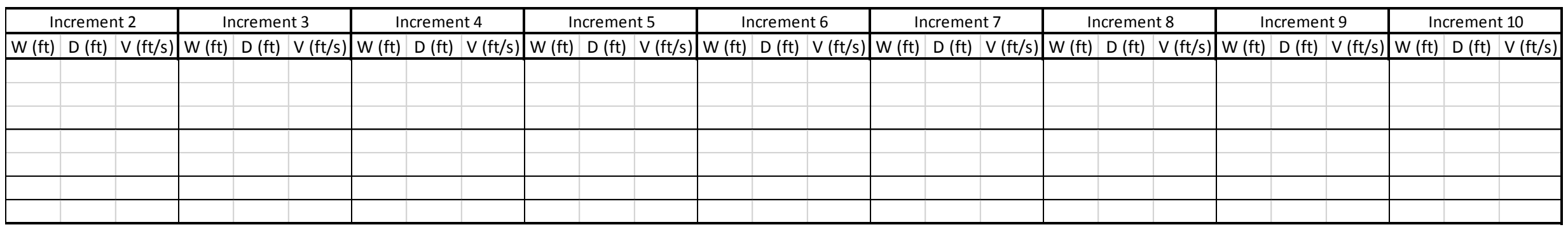

\begin{tabular}{|c|c|c|c|c|c|c|c|c|c|c|c|c|c|c|c|c|c|c|c|c|c|c|c|c|c|c|}
\hline \multicolumn{3}{|c|}{ Increment 2} & \multicolumn{3}{|c|}{ Increment 3} & \multicolumn{3}{|c|}{ Increment 4} & \multicolumn{3}{|c|}{ Increment 5} & \multicolumn{3}{|c|}{ Increment 6} & \multicolumn{3}{|c|}{ Increment 7} & \multicolumn{3}{|c|}{ Increment 8} & \multicolumn{3}{|c|}{ Increment 9} & \multicolumn{3}{|c|}{ Increment 10} \\
\hline$W(\mathrm{ft})$ & $D(\mathrm{ft})$ & $V(\mathrm{ft} / \mathrm{s})$ & $W(\mathrm{ft})$ & $\mathrm{D}(\mathrm{ft})$ & $V(\mathrm{ft} / \mathrm{s})$ & $W(\mathrm{ft})$ & $\mathrm{D}(\mathrm{ft})$ & $V(\mathrm{ft} / \mathrm{s})$ & $W(\mathrm{ft})$ & $D(\mathrm{ft})$ & $V(\mathrm{ft} / \mathrm{s})$ & W (ft) & $\mathrm{D}(\mathrm{ft})$ & $V(\mathrm{ft} / \mathrm{s})$ & $W(\mathrm{ft})$ & $\mathrm{D}(\mathrm{ft})$ & $V(\mathrm{ft} / \mathrm{s})$ & W (ft) & $\mathrm{D}(\mathrm{ft})$ & $V(\mathrm{ft} / \mathrm{s})$ & $W(\mathrm{ft})$ & $\mathrm{D}(\mathrm{ft})$ & $V(\mathrm{ft} / \mathrm{s})$ & W (ft) & $\mathrm{D}(\mathrm{ft})$ & $V(\mathrm{ft} / \mathrm{s})$ \\
\hline 2 & 1.05 & 0.87 & 2 & 1.05 & 0.83 & 2 & 1.2 & 0.29 & 2 & 0.9 & 0.76 & 2 & 0.85 & 1.07 & 2 & 0.45 & 0.55 & 2 & 0.75 & 0.86 & 2 & 0.5 & 0.68 & 1 & 0.3 & 0 \\
\hline & & & & & & & & & & & & & & & & & & & & & & & & & & \\
\hline 3 & 0.5 & 0.59 & 3 & 0.55 & 0.79 & 3 & 0.6 & 0.85 & 3 & 0.6 & 0.73 & 3 & 0.3 & 1.06 & 0.5 & 0.2 & 0.25 & & & & & & & & & \\
\hline 1 & 1 & 0.91 & 1 & 0.8 & 0.24 & 1 & 0.6 & 0.03 & 0.5 & 0.35 & 0.03 & & & & & & & & & & & & & & & \\
\hline
\end{tabular}

\begin{tabular}{|c|c|c|c|c|c|c|c|c|c|c|c|c|c|c|c|c|c|c|c|c|c|c|c|c|c|c|}
\hline \multicolumn{3}{|c|}{ Increment 2} & \multicolumn{3}{|c|}{ Increment 3} & \multicolumn{3}{|c|}{ Increment 4} & \multicolumn{3}{|c|}{ Increment 5} & \multicolumn{3}{|c|}{ Increment 6} & \multicolumn{3}{|c|}{ Increment 7} & \multicolumn{3}{|c|}{ Increment 8} & \multicolumn{3}{|c|}{ Increment 9} & \multicolumn{3}{|c|}{ Increment 10} \\
\hline$W(\mathrm{ft})$ & $D(\mathrm{ft})$ & $V(\mathrm{ft} / \mathrm{s})$ & $W(\mathrm{ft})$ & $D(\mathrm{ft})$ & $V(\mathrm{ft} / \mathrm{s})$ & W (ft) & $D(\mathrm{ft})$ & $V(\mathrm{ft} / \mathrm{s})$ & $W(\mathrm{ft})$ & $D(\mathrm{ft})$ & $V(\mathrm{ft} / \mathrm{s})$ & W (ft) & $D(\mathrm{ft})$ & $\mathrm{V}(\mathrm{ft} / \mathrm{s})$ & $W(\mathrm{ft})$ & $D(\mathrm{ft})$ & $\mathrm{V}(\mathrm{ft} / \mathrm{s})$ & $W(\mathrm{ft})$ & $D(\mathrm{ft})$ & $\mathrm{V}(\mathrm{ft} / \mathrm{s})$ & $W(\mathrm{ft})$ & $D(\mathrm{ft})$ & $V(\mathrm{ft} / \mathrm{s})$ & $W(\mathrm{ft})$ & $D(\mathrm{ft})$ & $V(\mathrm{ft} / \mathrm{s})$ \\
\hline 2 & 0.6 & 0.28 & 2 & 0.85 & 0.69 & 2 & 0.7 & 1.08 & 2 & 0.4 & 0.79 & 2 & 0.2 & 0.46 & 2 & 0.2 & 0.21 & 1.5 & 0.2 & 0 & & & & & & \\
\hline & & & & & & & & & & & & & & & & & & & & & & & & & & \\
\hline & & & & & & & & & & & & & & & & & & & & & & & & & & \\
\hline 1 & 0.2 & 0.51 & 1 & 0.2 & 1.13 & 0.25 & 0.1 & 0.01 & & & & & & & & & & & & & & & & & & \\
\hline 2 & 0.3 & 0.95 & 2 & 0.2 & 0.75 & 2 & 0.25 & 1.68 & 1 & 0.25 & 1.64 & & & & & & & & & & & & & & & \\
\hline 1 & 0.35 & 0.62 & 1 & 0.15 & 0.01 & 0.5 & 0.15 & 1.24 & & & & & & & & & & & & & & & & & & \\
\hline & & & & & & & & & & & & & & & & & & & & & & & & & & \\
\hline
\end{tabular}


Table 15: Condensed field and lab results.

\begin{tabular}{|c|c|c|c|c|c|c|c|c|c|c|c|c|c|c|c|c|c|c|c|c|}
\hline \multirow{2}{*}{$\begin{array}{c}\text { Sample } \\
\text { Set }\end{array}$} & \multirow{2}{*}{$\begin{array}{c}\text { Date } \\
\text { Sample } \\
\text { Taken }\end{array}$} & \multirow{2}{*}{$\begin{array}{l}\text { Sample } \\
\text { Type }\end{array}$} & \multirow[b]{2}{*}{ Site } & \multirow[b]{2}{*}{ Location/AMLIS } & \multicolumn{6}{|c|}{ Field Results } & \multicolumn{10}{|c|}{ Lab Results } \\
\hline & & & & & $\begin{array}{r}\text { Temp } \\
\left({ }^{\circ} \mathrm{C}\right)\end{array}$ & $\begin{array}{c}\text { Conductivity } \\
(\mu \mathrm{S} / \mathrm{cm})\end{array}$ & $\begin{array}{l}\text { TDS } \\
(\mathrm{mg} / \mathrm{l})\end{array}$ & $\begin{array}{c}D O \\
(\mathrm{mg} / \mathrm{l})\end{array}$ & $P H$ & $\begin{array}{c}\text { Flow } \\
\text { (gal/min) }\end{array}$ & $\mathrm{pH}^{*}$ & $\begin{array}{c}\text { Alk } \\
\mathrm{mg} / \mathrm{L}\end{array}$ & $\begin{array}{l}\mathrm{Acd} \\
\mathrm{mg} / \mathrm{L}\end{array}$ & $\begin{array}{c}\mathrm{SO} 4 \\
\mathrm{mg} / \mathrm{L}\end{array}$ & $\begin{array}{l}\text { Cond. } \\
\text { uS/cm }\end{array}$ & $\begin{array}{c}\mathrm{Al} \\
\mathrm{mg} / \mathrm{L}\end{array}$ & $\begin{array}{c}\mathrm{Ca} \\
\mathrm{mg} / \mathrm{L}\end{array}$ & $\begin{array}{c}\mathrm{Fe} \\
\mathrm{mg} / \mathrm{L}\end{array}$ & $\begin{array}{c}\mathrm{Mg} \\
\mathrm{mg} / \mathrm{L}\end{array}$ & $\begin{array}{c}\mathrm{Mn} \\
\mathrm{mg} / \mathrm{L}\end{array}$ \\
\hline 1 & 7/26/2013 & In-stream & Discharge & Mouth & 15.31 & 890 & 710 & 10.74 & 3 & 2602.4 & 3.03 & 0.5 & 280.66 & 416.5 & 1063 & 11.33 & 27.08 & 14.3 & 8.58 & 0.49 \\
\hline 1 & 7/26/2013 & In-stream & Discharge & US & 19.94 & 60 & 43 & 8.82 & 5.83 & N/A & 5.72 & 22.27 & 1.68 & 11.1 & 63.8 & 0.16 & 7.67 & 0.22 & 1.47 & 0.07 \\
\hline 1 & 7/26/2013 & In-stream & Discharge & DS & 19.15 & 224 & 164 & 10.18 & 3.9 & N/A & 3.84 & 0.5 & 65.11 & 95.9 & 265 & 3.49 & 14.2 & 2.14 & 3.94 & 0.2 \\
\hline 1 & 7/26/2013 & In-stream & Bottom Fork & US & 17.01 & 402 & 308 & 10.24 & 3.37 & N/A & 3.47 & 0.5 & 95.9 & 137 & 461 & 4.78 & 17.21 & 1.68 & 4.48 & 0.46 \\
\hline 1 & $7 / 26 / 2013$ & In-stream & Trib 1 & DS & 17.65 & 772 & 584 & 10 & 3.19 & 1751.0 & 3.39 & 0.5 & 86.27 & 119 & 436 & 4.32 & 16.6 & 2.35 & 4.21 & 0.54 \\
\hline 1 & $7 / 26 / 2013$ & In-stream & Heather Run & - & 18.72 & 766 & 566 & 9.76 & 3.01 & 131.1 & 3.02 & 0.5 & 167.76 & 264 & 869 & 7.78 & 24.43 & 6.05 & 6.95 & 0.74 \\
\hline 1 & $8 / 15 / 2013$ & Mine-site & Lick Run \#4 P1 & WV1820 & - & 1078 & 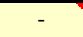 & - & 3.71 & 772.4 & 2.98 & 0.5 & 357.76 & 516 & 1382 & 12.84 & 22.16 & 22.75 & 8.26 & 0.41 \\
\hline 1 & 8/15/2013 & Mine-site & Lick Run \#4 P2 & WV1820 & 12.83 & 2179 & 1846 & 11.22 & 3.86 & 1425.9 & 2.53 & 0.5 & 1307.2 & 1430 & 2830 & 17.69 & 25.04 & 40.43 & 8.88 & 0.41 \\
\hline 1 & $8 / 15 / 2013$ & Mine-site & Lick Run \#4 P3 & WV1820 & - & - & - & - & - & - & - & - & - & - & - & - & 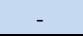 & - & - & - \\
\hline 1 & $8 / 15 / 2013$ & Mine-site & Lick Run \#2 & WV1822 & 18.7 & 1181 & 872 & 9.04 & 4 & 4.7 & 2.76 & 0.5 & 376.01 & 413 & 1343 & 11.36 & 17.59 & 16.44 & 5.67 & 0.52 \\
\hline 1 & $8 / 27 / 2013$ & Mine-site & Howesville Site 1 & WV1548 & 15.63 & 351 & 278 & 10.26 & 3.12 & 63.5 & 3.8 & 0.5 & 54.65 & 96.9 & 377 & 2.85 & 21.59 & 1.17 & 4.05 & 0.45 \\
\hline 1 & $8 / 27 / 2013$ & Mine-site & Howesville Greaser" & WV6422 & 15.92 & 1538 & 1210 & 9.14 & 2.41 & 95.3 & 2.82 & 0.5 & 527.73 & 595 & 1643 & 12.08 & 22.18 & 49.57 & 4.48 & 0.64 \\
\hline 2 & $10 / 8 / 2013$ & In-stream & Discharge & Mouth & 11.08 & 1316 & 1166 & 12.14 & 2.36 & 951.5 & 3.26 & 0.5 & 518.96 & 835 & 1710 & 37.93 & 68.45 & 54.27 & 25.72 & 1.38 \\
\hline 2 & $10 / 8 / 2013$ & In-stream & Discharge & US & 17.75 & 95 & 72 & 9.8 & 7.26 & N/A & 6.09 & 30.31 & 0.5 & 29.4 & 108 & 0.34 & 12.5 & 0.35 & 2.44 & 0.04 \\
\hline 2 & $10 / 8 / 2013$ & In-stream & Discharge & DS & 17.32 & 186 & 142 & 10.27 & 4.56 & N/A & 5.22 & 6.13 & 37.23 & 85.7 & 209 & 2.61 & 16.04 & 0.22 & 4.04 & 0.13 \\
\hline 2 & $10 / 8 / 2013$ & In-stream & Bottom Fork & Middle & 12.18 & 1013 & 872 & 9.73 & 2.8 & 188.5 & 3.26 & 0.5 & 380.65 & 570 & 1395 & 27.18 & 51.92 & 36.46 & 13.83 & 1.78 \\
\hline 2 & $10 / 8 / 2013$ & In-stream & Trib 1 & DS & 14.35 & 530 & 433 & 9.21 & 3.12 & 264.8 & 3.6 & 0.5 & 120.97 & 212 & 635 & 9.33 & 28.54 & 6.85 & 7.86 & 0.97 \\
\hline 2 & $10 / 15 / 2013$ & Mine-site & Lick Run \#4 P1 & WV1820 & 11.66 & 1430 & 1248 & 7.78 & 2.53 & 211.0 & 3.13 & 0.5 & 583.88 & 930 & 1779 & 43.94 & 62.03 & 62.9 & 26.96 & 1.18 \\
\hline 2 & $10 / 15 / 2013$ & Mine-site & Lick Run \#4 P2 & WV1820 & 12.63 & 2300 & 1958 & 10.34 & 2.42 & 228.9 & 2.97 & 0.5 & 1293.46 & 1970 & 2800 & 65.29 & 101.53 & 147.77 & 41.26 & 1.65 \\
\hline 2 & $10 / 15 / 2013$ & Mine-site & Lick Run \#4 P3 & WV1820 & 13.41 & 1327 & 1116 & 8.22 & 2.96 & 67.3 & 3.25 & 0.5 & 606.06 & 1050 & 1559 & 43.6 & 75.67 & 71.53 & 25.33 & 1.64 \\
\hline 2 & $10 / 15 / 2013$ & Mine-site & Howesville Site 1 & WV1548 & 14.14 & 306 & 251 & 8.09 & 6.49 & 4.5 & 5.74 & 17.25 & 14.55 & 116 & 340 & 0.12 & 32.02 & 0.17 & 6.07 & 1.14 \\
\hline 2 & $10 / 15 / 2013$ & Mine-site & Howesville Greaser & WV6422 & 15.12 & 2148 & 1721 & 8.53 & 2.49 & 9.0 & 2.92 & 0.5 & 961.67 & 1150 & 2530 & 42.53 & 62.49 & 138.52 & 14.35 & 1.63 \\
\hline 2 & $12 / 2 / 2013$ & Mine-site & Lick Run \#2 & WV1822 & 6.07 & 826 & 841 & 12.81 & 3.28 & 7.6 & 3.11 & 0.5 & 368.97 & 348.5 & 1182 & 19.41 & 29.52 & 29.93 & 10.61 & 0.86 \\
\hline 3 & $3 / 10 / 2014$ & In-stream & Discharge & Mouth & 3.89 & 491 & 534 & 13.51 & 1.64 & 5197.7 & 3.5 & 0.5 & 205.82 & 231 & 760 & 14.57 & 31.91 & 25.7 & 11.51 & 0.64 \\
\hline 3 & $3 / 10 / 2014$ & In-stream & Discharge & US & 4.32 & 43 & 46 & 13.06 & 4.86 & N/A & 5.24 & 20.45 & 8.17 & 13.9 & 67.3 & 0.05 & 7.51 & 0.02 & 1.56 & 0.01 \\
\hline 3 & $3 / 10 / 2014$ & In-stream & Discharge & DS & 4.2 & 197 & 212 & 13.47 & 2.39 & N/A & 4.05 & 0.5 & 56.58 & 80.7 & 288 & 3.77 & 12.97 & 4.73 & 3.76 & 0.18 \\
\hline 3 & 3/10/2014 & In-stream & Trib 1 & DS & 6.41 & 242 & 244 & 11.97 & 3.11 & 2698.4 & 3.81 & 0.5 & 74.02 & 90.1 & 356 & 4.11 & 13.12 & 4.68 & 3.7 & 0.35 \\
\hline 3 & 3/10/2014 & Mine-site & Lick Run \#4 P1 & WV1820 & 10.81 & 1334 & 1190 & 7.88 & 2.33 & 610.2 & 3.13 & 0.5 & 567.37 & 729 & 1697 & 45.34 & 57.73 & 68.85 & 25.49 & 0.91 \\
\hline 3 & 3/10/2014 & Mine-site & Lick Run \#4 P2 & WV1820 & 12.38 & 2123 & 1819 & 8.35 & 2.3 & 536.1 & 2.92 & 0.5 & 1102.35 & 1440 & 2620 & 59.64 & 89.18 & 147.75 & 38.78 & 1.77 \\
\hline 3 & $3 / 10 / 2014$ & Mine-site & Lick Run \#4 P3 & WV1820 & 4.3 & 433 & 465 & 12.56 & 2.91 & 1432.4 & 3.58 & 0.5 & 153.18 & 266 & 704 & 12.97 & 32.61 & 20.66 & 10.44 & 0.62 \\
\hline 3 & $3 / 10 / 2014$ & Mine-site & Howesville Site 1 & WV1548 & 10.14 & 235 & 213 & 10.62 & 3.98 & 203.1 & 4.65 & 2.65 & 49.93 & 72.7 & 317 & 2.63 & 24.87 & 0.94 & 4.36 & 0.48 \\
\hline 3 & $3 / 10 / 2014$ & Mine-site & Lick Run \#2 & WV1822 & 11.34 & 1306 & 1149 & 10.37 & 2.46 & 8.5 & 3.07 & 0.5 & 525.67 & 658 & 1662 & 38.37 & 47.48 & 80.64 & 17.7 & 0.92 \\
\hline 3 & $3 / 11 / 2014$ & Mine-site & Howesville Greaser & WV6422 & 6.49 & 885 & 890 & 11.77 & 2.59 & 57.5 & 3.14 & 0.5 & 388.3 & 211 & 1294 & 16.94 & 33.9 & 86.18 & 7.66 & 1.25 \\
\hline 3 & $3 / 12 / 2014$ & In-stream & Bottom Fork & Middle & 5.71 & 317 & 326 & 12.46 & 2.84 & 515.4 & 3.62 & 0.5 & 113.23 & 133 & 468 & 6.43 & 16.77 & 7.82 & 4.25 & 0.38 \\
\hline 4 & $5 / 12 / 2014$ & In-stream & Discharge & Mouth & 14.2 & 1031 & 844 & 10.51 & 2.35 & 1969.9 & 3.44 & 0.5 & 425.96 & 578 & 1341 & 26.55 & 50.44 & 27.51 & 17.25 & 0.68 \\
\hline 4 & $5 / 12 / 2014$ & In-stream & Discharge & US & 19.36 & 68 & 49 & 12.62 & 5.65 & N/A & 5.63 & 30.71 & 15.28 & 15.6 & 75.3 & 0.13 & 7.54 & 0.01 & 1.59 & 0.02 \\
\hline 4 & $5 / 12 / 2014$ & In-stream & Discharge & DS & 17.76 & 481 & 361 & 13.97 & 3.01 & N/A & 3.85 & 0.5 & 134.69 & 179 & 546 & 8.95 & 22.15 & 5.01 & 6.72 & 0.19 \\
\hline 4 & $5 / 12 / 2014$ & In-stream & Bottom Fork & Middle & 17.77 & 906 & 683 & 11.48 & 2.59 & 178.2 & 3.52 & 0.5 & 296.58 & 336 & 1132 & 18.76 & 37.43 & 13.33 & 9 & 0.84 \\
\hline 4 & $5 / 12 / 2014$ & In-stream & Trib 1 & DS & 19.73 & 529 & 382 & 17.36 & 3.12 & 956.0 & 3.8 & 0.5 & 153.83 & 175 & 602 & 8.4 & 23.61 & 15.75 & 6.3 & 0.69 \\
\hline 4 & $5 / 12 / 2014$ & Mine-site & Lick Run \#2 & WV1822 & 22.41 & 1828 & 1250 & 13.23 & 2.58 & 5.7 & 3.26 & 0.5 & 673.62 & 726 & 2060 & 41.6 & 55.23 & 46.35 & 17.39 & 1.13 \\
\hline 4 & $5 / 21 / 2014$ & \begin{tabular}{|l|} 
Mine-site \\
\end{tabular} & Lick Run \#4 P1 & WV1820 & 10.89 & 1240 & 1103 & 2.76 & 2.21 & 410.2 & 3.46 & 0.5 & 577.71 & 628 & 1548 & 36.31 & 45.65 & 58.55 & 20.13 & 0.83 \\
\hline 4 & $5 / 21 / 2014$ & Mine-site & Lick Run \#4 P2 & WV1820 & 12.65 & 2146 & 1826 & 9.56 & 2.57 & 550.5 & 3.1 & 0.5 & 1102.79 & 1226 & 2560 & 50.83 & 69 & 123.78 & 28.83 & 1.18 \\
\hline 4 & $5 / 21 / 2014$ & Mine-site & Lick Run \#4 P3 & WV1820 & 14.44 & 663 & 541 & 1.98 & 3.12 & 771.8 & 3.67 & 0.5 & 214.38 & 302 & 796 & 15 & 35.7 & 23.5 & 11.27 & 0.51 \\
\hline 4 & 5/27/2014 & In-stream & Trib 1 & Mouth & 15.93 & 560 & 440 & 10.28 & 2.57 & 185.1 & 3.56 & 0.5 & 193.48 & 231.5 & 703 & 13.1 & 39.96 & 3.53 & 10.47 & 0.45 \\
\hline 4 & $5 / 27 / 2014$ & In-stream & Trib 1 & US & 16.76 & 435 & 336 & 10.39 & 2.75 & 770.9 & 3.55 & 0.5 & 113.81 & 140 & 526 & 6.48 & 17.98 & 3.95 & 5.13 & 0.49 \\
\hline 4 & $5 / 27 / 2014$ & Mine-site & Howesville Site 1 & WV1548 & 14.85 & 319 & 257 & 8.74 & 2.8 & 27.9 & 4.97 & 9.25 & 39.63 & 84.5 & 311 & 3.77 & 22.53 & 0.01 & 4.97 & 0.86 \\
\hline 4 & $5 / 27 / 2014$ & Mine-site & Howesville Greaser & WV6422 & 15.75 & 1376 & 1087 & 9 & 2.38 & 34.1 & 3.13 & 0.5 & 539.62 & 506 & 1694 & 18.13 & 38.94 & 76.81 & 7.81 & 1.17 \\
\hline
\end{tabular}




\subsection{Appendix B: Biological Integrity}

Table 16: Benthic Macro-invertebrate sampling points.

\begin{tabular}{|c|c|c|c|c|c|c|c|}
\hline \multirow{2}{*}{ Source } & \multirow{2}{*}{ Location } & \multicolumn{3}{|c|}{ Lattitude } & \multicolumn{3}{|c|}{ Longitude } \\
\hline & & DDD MM SS & DDD MM.MMM & DDD.DDDD & DDD MM SS & DDD MM.MMM & DDD.DDDD \\
\hline Nothern Start & - & $39^{\circ} 26^{\prime} 25^{\prime \prime} \mathrm{N}$ & $x$ & $\mathrm{x}$ & $79^{\circ} 44^{\prime} 48^{\prime \prime W}$ & $x$ & $x$ \\
\hline Southern Start & - & $39^{\circ} 25^{\prime} 49^{\prime \prime} \mathrm{N}$ & $x$ & $x$ & $79^{\circ} 45^{\prime} 30^{\prime \prime W}$ & $x$ & $x$ \\
\hline Middle Start & - & $39^{\circ} 26^{\prime} 05^{\prime \prime} \mathrm{N}$ & $x$ & $x$ & $79^{\circ} 43^{\prime} 53^{\prime \prime} \mathrm{W}$ & $x$ & $x$ \\
\hline \multirow{3}{*}{ Top Fork } & North & $39^{\circ} 25^{\prime} 40^{\prime \prime} \mathrm{N}$ & $x$ & $x$ & $79^{\circ} 44^{\prime} 24^{\prime \prime W}$ & $x$ & $x$ \\
\hline & South & $39^{\circ} 25^{\prime} 39^{\prime \prime} \mathrm{N}$ & $x$ & $x$ & $79^{\circ} 44^{\prime} 25^{\prime \prime W}$ & $x$ & $x$ \\
\hline & DS & $39^{\circ} 25^{\prime} 38^{\prime \prime} \mathrm{N}$ & $x$ & $x$ & $79^{\circ} 44^{\prime} 23^{\prime \prime W}$ & $x$ & $x$ \\
\hline \multirow{3}{*}{ Trib 1} & Mouth & $x$ & $x$ & $x$ & $x$ & $x$ & $x$ \\
\hline & US & $x$ & $x$ & $x$ & $x$ & $x$ & $x$ \\
\hline & DS & $39^{\circ} 25^{\prime} 10^{\prime \prime} \mathrm{N}$ & $39^{\circ} 25.168^{\prime} \mathrm{N}$ & 39.419467 & $79^{\circ} 43^{\prime} 23^{\prime \prime} \mathrm{W}$ & $79^{\circ} 43.384^{\prime} \mathrm{W}$ & -79.723067 \\
\hline \multirow{3}{*}{ Bottom Fork } & Middle & $39^{\circ} 25^{\prime} 54^{\prime \prime} \mathrm{N}$ & $39^{\circ} 25.900^{\prime} \mathrm{N}$ & 39.431667 & $79^{\circ} 42^{\prime} 56^{\prime \prime} \mathrm{W}$ & $79^{\circ} 42.933^{\prime} \mathrm{W}$ & -79.715556 \\
\hline & US & $39^{\circ} 25^{\prime} 32^{\prime \prime} \mathrm{N}$ & $x$ & $x$ & $79^{\circ} 42^{\prime} 21^{\prime \prime W}$ & $x$ & $x$ \\
\hline & DS & $39^{\circ} 25^{\prime} 33^{\prime \prime} \mathrm{N}$ & $x$ & $x$ & $79^{\circ} 42^{\prime} 18^{\prime \prime W}$ & $x$ & $x$ \\
\hline \multirow{3}{*}{ Discharge } & Mouth & $39^{\circ} 25^{\prime} 26^{\prime \prime} \mathrm{N}$ & $39^{\circ} 25.437^{\prime} \mathrm{N}$ & 39.42395 & $79^{\circ} 41^{\prime} 18^{\prime \prime} \mathrm{W}$ & $79^{\circ} 41.314^{\prime} \mathrm{W}$ & -79.688567 \\
\hline & US & $39^{\circ} 25^{\prime} 33^{\prime \prime} \mathrm{N}$ & $x$ & $x$ & $79^{\circ} 41^{\prime} 08^{\prime \prime W}$ & $x$ & $x$ \\
\hline & DS & $39^{\circ} 25^{\prime} 38^{\prime \prime} \mathrm{N}$ & $x$ & $x$ & $79^{\circ} 41^{\prime} 14^{\prime \prime W}$ & $x$ & $x$ \\
\hline
\end{tabular}


Table 17: WVSCl assessment results - Trib 1 DS - sample set 1.

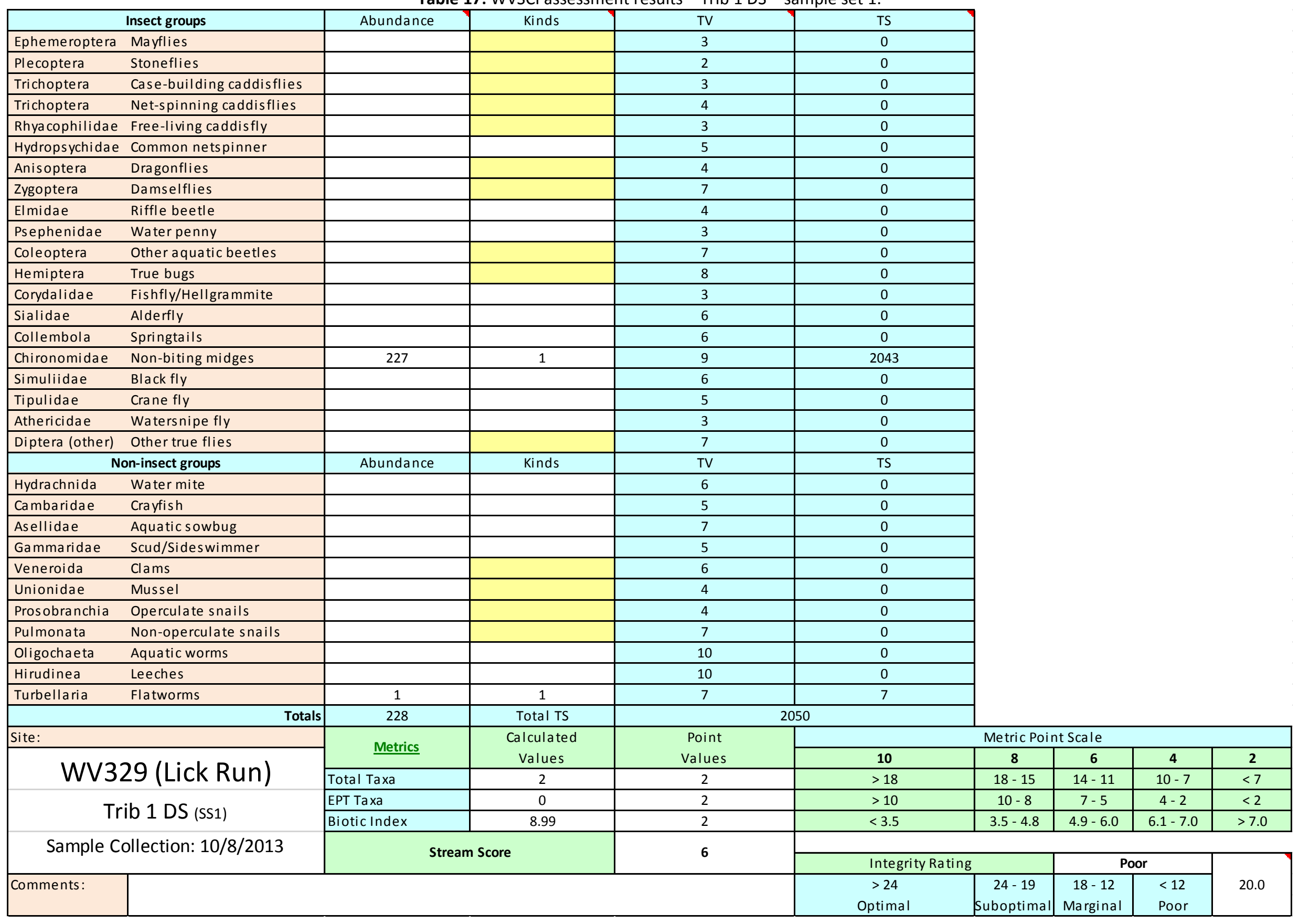


Table 18: WVSCl assessment results - Trib 1 DS - sample set 2.

\begin{tabular}{|c|c|c|c|c|c|c|c|c|c|}
\hline \multicolumn{2}{|r|}{ Insect groups } & \multirow{2}{*}{ Abundance } & \multirow{2}{*}{ Kinds } & \multicolumn{2}{|l|}{ TV } & & & & \\
\hline Ephemeroptera & Mayflies & & & 3 & 0 & & & & \\
\hline Plecoptera & Stoneflies & & & 2 & 0 & & & & \\
\hline Trichoptera & Case-building caddisflies & & & 3 & 0 & & & & \\
\hline Trichoptera & Net-spinning caddisflies & & & 4 & 0 & & & & \\
\hline Rhyacophilidae & Free-living caddisfly & & & 3 & 0 & & & & \\
\hline Hydropsychidae & Common netspinner & & & 5 & 0 & & & & \\
\hline Anisoptera & Dragonflies & & & 4 & 0 & & & & \\
\hline Zygoptera & Damselflies & & & 7 & 0 & & & & \\
\hline Elmidae & Riffle beetle & & & 4 & 0 & & & & \\
\hline Psephenidae & Water penny & & & 3 & 0 & & & & \\
\hline Coleoptera & Other aquatic beetles & & & 7 & 0 & & & & \\
\hline Hemiptera & True bugs & & & 8 & 0 & & & & \\
\hline Corydalidae & Fishfly/Hellgrammite & & & 3 & 0 & & & & \\
\hline Sialidae & Alderfly & & & 6 & 0 & & & & \\
\hline Collembola & Springtails & & & 6 & 0 & & & & \\
\hline Chironomidae & Non-biting midges & & & 9 & 0 & & & & \\
\hline Simuliidae & Black fly & & & 6 & 0 & & & & \\
\hline Tipulidae & Crane fly & & & 5 & 0 & & & & \\
\hline Athericidae & Watersnipe fly & & & 3 & 0 & & & & \\
\hline Diptera (other) & Other true flies & & & 7 & 0 & & & & \\
\hline & Abundance & Kinds & TV & TS & & & & \\
\hline \multicolumn{2}{|c|}{$\begin{array}{lc} & \text { Non-Insect groups } \\
\text { Hydrachnida } & \text { Water mite }\end{array}$} & & & 6 & 0 & & & & \\
\hline Cambaridae & Crayfish & & & 5 & 0 & & & & \\
\hline Asellidae & Aquatic sowbug & & & 7 & 0 & & & & \\
\hline Gammaridae & Scud/Sideswimmer & & & 5 & 0 & & & & \\
\hline Veneroida & Clams & & & 6 & 0 & & & & \\
\hline Unionidae & Mussel & & & 4 & 0 & & & & \\
\hline Prosobranchia & Operculate snails & & & 4 & 0 & & & & \\
\hline Pulmonata & Non-operculate snails & & & 7 & 0 & & & & \\
\hline Oligochaeta & Aquatic worms & & & 10 & 0 & & & & \\
\hline Hirudinea & Leeches & & & 10 & 0 & & & & \\
\hline Turbellaria & Flatworms & & & 7 & 0 & & & & \\
\hline \multicolumn{2}{|r|}{ Totals } & 0 & Total TS & \multicolumn{2}{|c|}{0} & & & & \\
\hline \multicolumn{2}{|l|}{ Site: } & \multirow{2}{*}{$\underline{\text { Metrics }}$} & Calculated & Point & \multicolumn{5}{|c|}{ Metric Point Scale } \\
\hline \multirow{2}{*}{\multicolumn{2}{|c|}{ WV329 (Lick Run) }} & & Values & Values & 10 & 8 & 6 & 4 & 2 \\
\hline & & Total Taxa & 0 & 2 & $>18$ & $18-15$ & $14-11$ & $10-7$ & $<7$ \\
\hline \multirow{2}{*}{\multicolumn{2}{|c|}{ Trib 1 DS (ss2) }} & EPT Таха & 0 & 2 & $>10$ & $10-8$ & $7-5$ & $4-2$ & $<2$ \\
\hline & & Biotic Index & \#DIV/0! & \#DIV/0! & $<3.5$ & $3.5-4.8$ & $4.9-6.0$ & $6.1-7.0$ & $>7.0$ \\
\hline \multirow{2}{*}{\multicolumn{2}{|c|}{ Sample Collection: 5/12/2014 }} & \multirow{2}{*}{\multicolumn{2}{|c|}{ Stream Score }} & \multirow{3}{*}{ \#DIV/0! } & & & & & \\
\hline & & & & & Integrit & & \#D & & \\
\hline Comments: & & *Not & & & $\begin{array}{c}>24 \\
\text { Optimal }\end{array}$ & $\begin{array}{c}24-19 \\
\text { Suboptimal }\end{array}$ & $\begin{array}{c}18-12 \\
\text { Marginal }\end{array}$ & $\begin{array}{l}<12 \\
\text { Poor }\end{array}$ & \#DIV/0! \\
\hline
\end{tabular}


Table 19: WVSCl assessment results - Bottom Fork Middle - sample set 1.

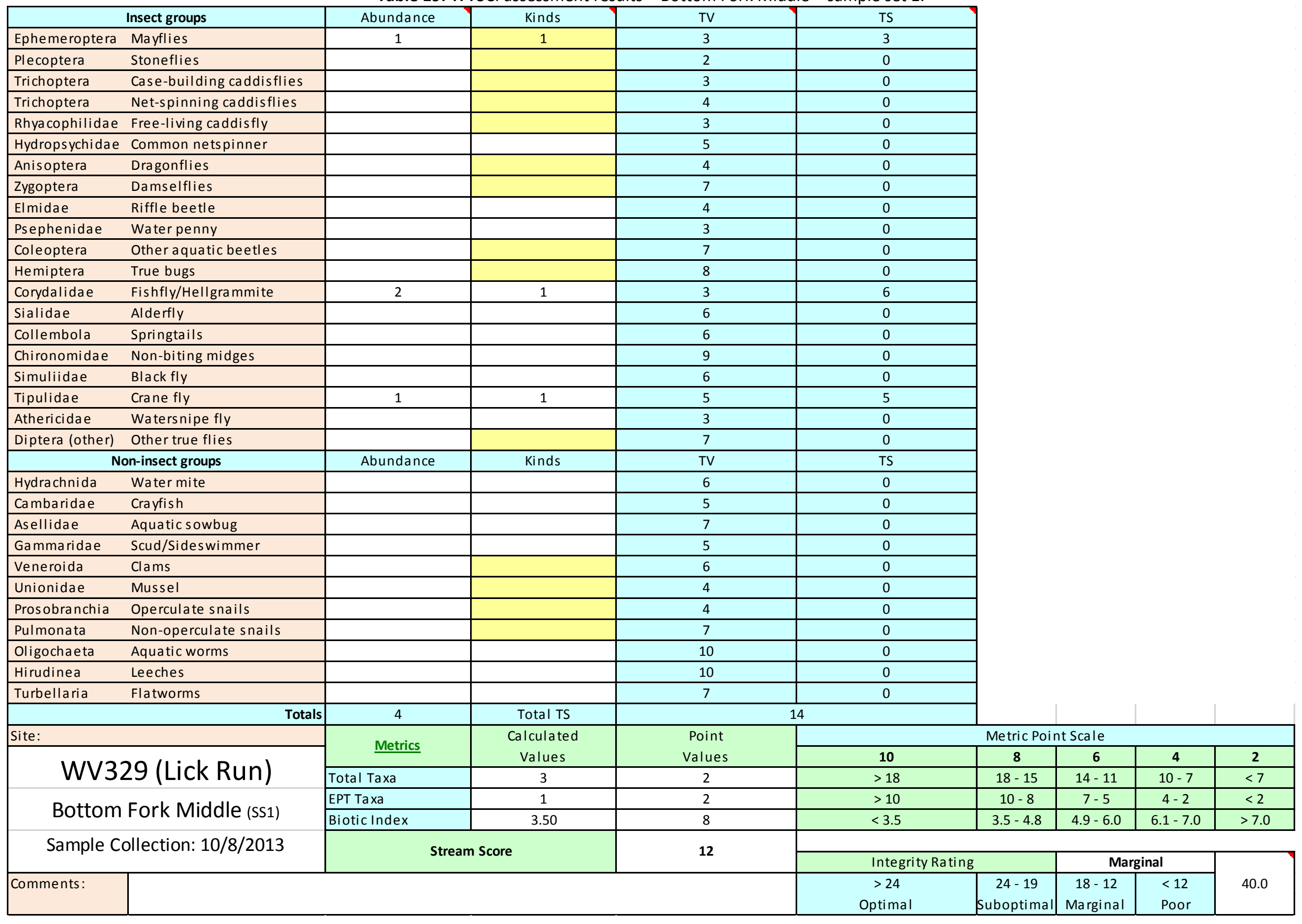


Table 20: WVSCl assessment results - Bottom Fork Middle - sample set 2.

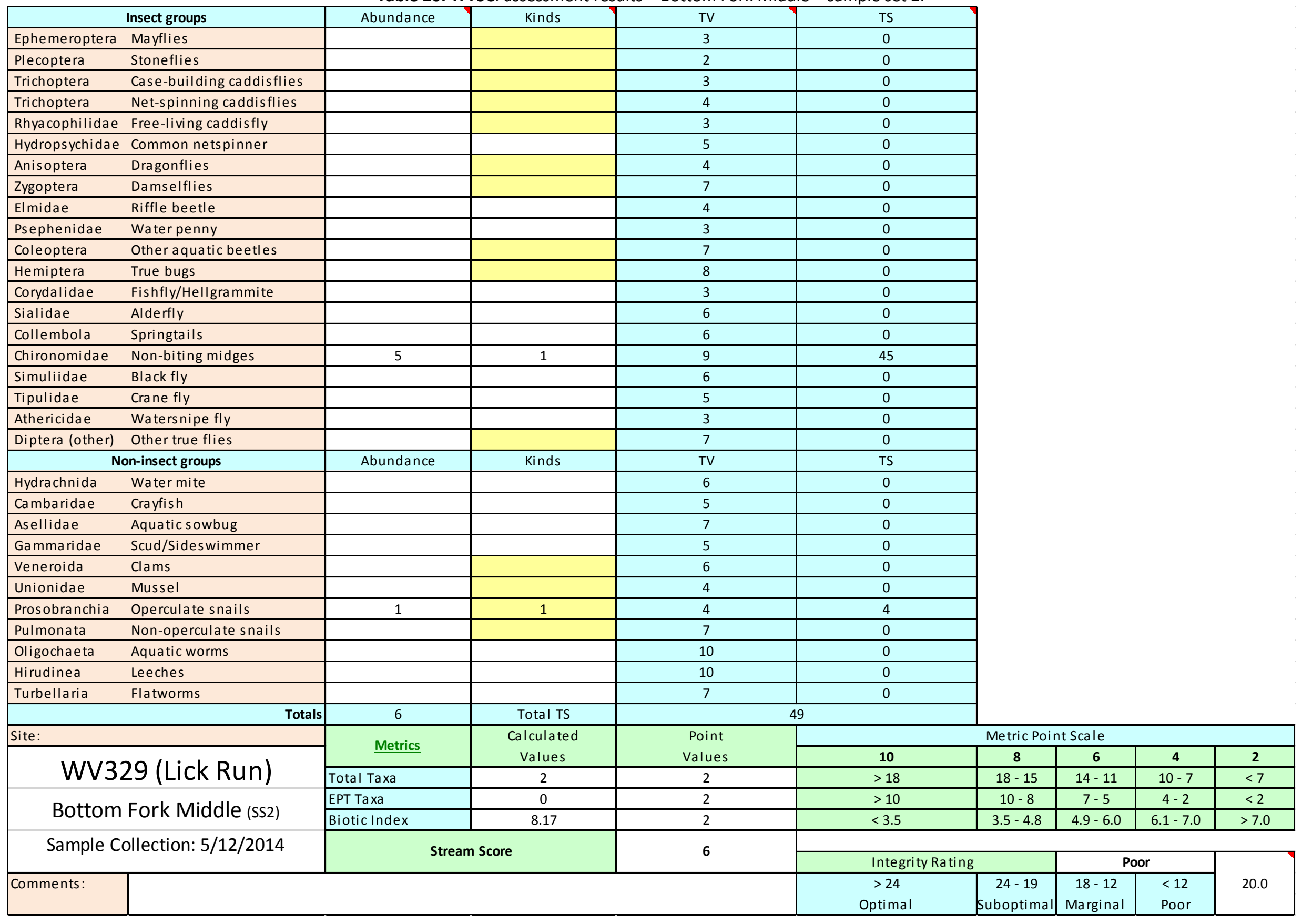


Table 21: WVSCl assessment results - Discharge Mouth - sample set 1.

\begin{tabular}{|c|c|c|c|c|c|c|c|c|c|}
\hline \multicolumn{2}{|r|}{ Insect groups } & \multirow[t]{2}{*}{ Abundance } & \multirow[t]{2}{*}{ Kinds } & \multirow{2}{*}{$\begin{array}{c}\text { TV } \\
3 \\
\end{array}$} & \multirow{2}{*}{$\begin{array}{c}\mathrm{TS} \\
0\end{array}$} & & & & \\
\hline Ephemeroptera & Mayflies & & & & & & & & \\
\hline \multicolumn{2}{|l|}{ Plecoptera } & & & 2 & 0 & & & & \\
\hline \multicolumn{2}{|r|}{ Case-building caddisflies } & & & 3 & 0 & & & & \\
\hline \multicolumn{2}{|r|}{ Net-spinning caddisflies } & & & 4 & 0 & & & & \\
\hline \multicolumn{2}{|c|}{ Rhyacophilidae Free-living caddisfly } & & & 3 & 0 & & & & \\
\hline \multicolumn{2}{|c|}{ Hydropsychidae Common netspinner } & & & 5 & 0 & & & & \\
\hline \multicolumn{2}{|r|}{ Dragonflies } & & & 4 & 0 & & & & \\
\hline \multicolumn{2}{|r|}{ Damselflies } & & & 7 & 0 & & & & \\
\hline \multicolumn{2}{|r|}{ Riffle beetle } & & & 4 & 0 & & & & \\
\hline \multicolumn{2}{|l|}{ Psephenidae } & & & 3 & 0 & & & & \\
\hline \multicolumn{2}{|r|}{ Other aquatic beetles } & & & 7 & 0 & & & & \\
\hline \multicolumn{2}{|l|}{ Hemiptera } & & & 8 & 0 & & & & \\
\hline \multicolumn{2}{|r|}{ Fishfly/Hellgrammite } & 1 & 1 & 3 & 3 & & & & \\
\hline \multicolumn{2}{|l|}{ Sialidae } & & & 6 & 0 & & & & \\
\hline \multicolumn{2}{|l|}{ Collembola } & & & 6 & 0 & & & & \\
\hline \multicolumn{2}{|r|}{ Non-biting midges } & & & 9 & 0 & & & & \\
\hline \multicolumn{2}{|l|}{ Simuliidae } & & & 6 & 0 & & & & \\
\hline \multicolumn{2}{|l|}{ Tipulidae } & & & 5 & 0 & & & & \\
\hline \multicolumn{2}{|r|}{ Watersnipe fly } & & & 3 & 0 & & & & \\
\hline Diptera (other) & Other true flies & & & 7 & 0 & & & & \\
\hline & on-insect groups & Abundance & Kinds & TV & TS & & & & \\
\hline Hydra chnida & Water mite & & & 6 & 0 & & & & \\
\hline Cambaridae & Crayfish & & & 5 & 0 & & & & \\
\hline Asellidae & Aquatic sowbug & & & 7 & 0 & & & & \\
\hline Gammaridae & Scud/Sideswimmer & & & 5 & 0 & & & & \\
\hline Veneroida & Clams & & & 6 & 0 & & & & \\
\hline Unionidae & Mussel & & & 4 & 0 & & & & \\
\hline Prosobranchia & Operculate snails & & & 4 & 0 & & & & \\
\hline Pulmonata & Non-operculate snails & & & 7 & 0 & & & & \\
\hline Oligochaeta & Aquatic worms & & & 10 & 0 & & & & \\
\hline Hirudinea & Leeches & & & 10 & 0 & & & & \\
\hline Turbellaria & Flatworms & & & 7 & 0 & & & & \\
\hline & Totals & 1 & Total TS & & & & & & \\
\hline Site: & & Metrics & Calculated & Point & & Metric Poin & t Scale & & \\
\hline & & thetimes & Values & Values & 10 & 8 & 6 & 4 & 2 \\
\hline WV32 & 29 (LICK Run) & Total Taxa & 1 & 2 & $>18$ & $18-15$ & $14-11$ & $10-7$ & $<7$ \\
\hline Discha & arge Mouth (ss1) & EPT Таха & 0 & 2 & $>10$ & $10-8$ & $7-5$ & $4-2$ & $<2$ \\
\hline viscid & age iviouth (SSI) & Biotic Index & 3.00 & 10 & $<3.5$ & $3.5-4.8$ & $4.9-6.0$ & $6.1-7.0$ & $>7.0$ \\
\hline Sample Co & ollection: $10 / 8 / 2013$ & & & 14 & & & & & \\
\hline & & & & & Integrit & & Mar & inal & \\
\hline Comments: & & & & & $\begin{array}{c}>24 \\
\text { Optimal }\end{array}$ & $\begin{array}{c}24-19 \\
\text { Suboptimal }\end{array}$ & $\begin{array}{c}18-12 \\
\text { Marginal }\end{array}$ & $\begin{array}{l}<12 \\
\text { Poor }\end{array}$ & 46.7 \\
\hline
\end{tabular}


Table 22: $\mathrm{WVSCl}$ assessment results - Discharge Mouth - sample set 2.

\begin{tabular}{|c|c|c|c|c|c|c|c|c|c|}
\hline & Insect groups & Abundance & Kinds & TV & TS & & & & \\
\hline Ephemeroptera & Mayflies & & & 3 & 0 & & & & \\
\hline Plecoptera & Stoneflies & & & 2 & 0 & & & & \\
\hline Trichoptera & Case-building caddisflies & & & 3 & 0 & & & & \\
\hline Trichoptera & Net-spinning caddisflies & & & 4 & 0 & & & & \\
\hline Rhyacophilidae & Free-living caddisfly & & & 3 & 0 & & & & \\
\hline Hydropsychidae & Common netspinner & & & 5 & 0 & & & & \\
\hline Anisoptera & Dragonflies & & & 4 & 0 & & & & \\
\hline Zygoptera & Damselflies & & & 7 & 0 & & & & \\
\hline Elmidae & Riffle beetle & & & 4 & 0 & & & & \\
\hline Psephenidae & Water penny & & & 3 & 0 & & & & \\
\hline Coleoptera & Other aquatic beetles & & & 7 & 0 & & & & \\
\hline Hemiptera & True bugs & & & 8 & 0 & & & & \\
\hline Corydalidae & Fishfly/Hellgrammite & & & 3 & 0 & & & & \\
\hline Sialidae & Alderfly & & & 6 & 0 & & & & \\
\hline Collembola & Springtails & & & 6 & 0 & & & & \\
\hline Chironomidae & Non-biting midges & & & 9 & 0 & & & & \\
\hline Simuliidae & Black fly & & & 6 & 0 & & & & \\
\hline Tipulidae & Crane fly & & & 5 & 0 & & & & \\
\hline Athericidae & Watersnipe fly & & & 3 & 0 & & & & \\
\hline Diptera (other) & Other true flies & & & 7 & 0 & & & & \\
\hline \multicolumn{2}{|c|}{ Non-insect groups } & Abundance & Kinds & TV & TS & & & & \\
\hline Hydrachnida & Water mite & & & 6 & 0 & & & & \\
\hline Cambaridae & Crayfish & & & 5 & 0 & & & & \\
\hline Asellidae & Aquatic sowbug & & & 7 & 0 & & & & \\
\hline Gammaridae & Scud/Sideswimmer & & & 5 & 0 & & & & \\
\hline Veneroida & Clams & & & 6 & 0 & & & & \\
\hline Unionidae & Mussel & & & 4 & 0 & & & & \\
\hline Prosobranchia & Operculate snails & & & 4 & 0 & & & & \\
\hline Pulmonata & Non-operculate snails & & & 7 & 0 & & & & \\
\hline Oligochaeta & Aquatic worms & & & 10 & 0 & & & & \\
\hline Hirudinea & Leeches & & & 10 & 0 & & & & \\
\hline Turbellaria & Flatworms & & & 7 & 0 & & & & \\
\hline & Totals & 0 & Total TS & \multicolumn{2}{|c|}{0} & & & & \\
\hline \multicolumn{2}{|c|}{\begin{tabular}{|l|} 
Site: \\
\end{tabular}} & \multirow{2}{*}{$\underline{\text { Metrics }}$} & Calculated & Point & \multicolumn{5}{|c|}{ Metric Point Scale } \\
\hline \multirow{2}{*}{\multicolumn{2}{|c|}{ WV329 (Lick Run) }} & & Values & Values & 10 & 8 & 6 & 4 & 2 \\
\hline & & Total Taxa & 0 & 2 & $>18$ & $18-15$ & $14-11$ & $10-7$ & $<7$ \\
\hline \multirow{2}{*}{\multicolumn{2}{|c|}{ Discharge Mouth (ss2) }} & EPT Таха & 0 & 2 & $>10$ & $10-8$ & $7-5$ & $4-2$ & $<2$ \\
\hline & & Biotic Index & \#DIV/0! & \#DIV/0! & $<3.5$ & $3.5-4.8$ & $4.9-6.0$ & $6.1-7.0$ & $>7.0$ \\
\hline \multirow{2}{*}{\multicolumn{2}{|c|}{ Sample Collection: 5/12/2014 }} & \multirow{2}{*}{\multicolumn{2}{|c|}{ Stream Score }} & \multirow{3}{*}{ \#DIV/0! } & & & & & \multirow[b]{3}{*}{ \#DIV/0! } \\
\hline & & & & & Integrit & & \multicolumn{2}{|c|}{ \#DIV/0! } & \\
\hline Comments: & \multicolumn{3}{|c|}{ *Nothing found } & & $\begin{array}{c}>24 \\
\text { Optimal } \\
\end{array}$ & $\mid \begin{array}{c}24-19 \\
\text { Suboptimal }\end{array}$ & $\begin{array}{c}18 \text { - } 12 \\
\text { Marginal } \\
\end{array}$ & $\begin{array}{l}<12 \\
\text { Poor }\end{array}$ & \\
\hline
\end{tabular}


8.3 Appendix C: AMD Treat Reports 
Project Lick Run WV329

Site Name Howesville Greaser

Costs

\begin{tabular}{|c|c|c|c|}
\hline Passive Treatment & $\underline{A}$ & $\underline{\mathbf{S}}$ & \\
\hline Vertical Flow Pond & & & $\$ 0$ \\
\hline Anoxic Limestone Drain & & & $\$ 0$ \\
\hline Anaerobic Wetlands & & & $\$ 0$ \\
\hline Aerobic Wetlands & 1 & 0 & $\$ 55,216$ \\
\hline Manganese Removal Bed & & & $\$ 0$ \\
\hline Oxic Limestone Channel & 2 & 0 & $\$ 4,392$ \\
\hline Limestone Bed & 1 & 0 & $\$ 7,925$ \\
\hline BIO Reactor & & & $\$ 0$ \\
\hline \multicolumn{3}{|l|}{ Passive Subtotal: } & $\$ 67,533$ \\
\hline \multicolumn{4}{|l|}{ Active Treatment } \\
\hline Caustic Soda & & & $\$ 0$ \\
\hline Hydrated Lime & & & $\$ 0$ \\
\hline Pebble Quick Lime & & & $\$ 0$ \\
\hline Ammonia & & & $\$ 0$ \\
\hline Oxidants & & & $\$ 0$ \\
\hline Soda Ash & & & $\$ 0$ \\
\hline \multicolumn{3}{|l|}{ Active Subtotal: } & $\$ 0$ \\
\hline \multicolumn{4}{|l|}{ Ancillary Cost } \\
\hline Ponds & 1 & 0 & $\$ 10,303$ \\
\hline Roads & & & $\$ 0$ \\
\hline Land Access & & & $\$ 0$ \\
\hline Ditching & & & $\$ 0$ \\
\hline Engineering Cost & 1 & 0 & $\$ 9,340$ \\
\hline \multicolumn{3}{|l|}{ Ancillary Subtotal: } & $\$ 19,643$ \\
\hline \multicolumn{3}{|l|}{ Other Cost (Capital Cost) } & $\$ 0$ \\
\hline \multicolumn{3}{|l|}{ Total Capital Cost: } & $\$ 87,176$ \\
\hline \multicolumn{4}{|l|}{ Annual Costs } \\
\hline Sampling & & & $\$ 0$ \\
\hline Labor & & & $\$ 0$ \\
\hline Maintenance & & & $\$ 0$ \\
\hline Pumping & & & $\$ 0$ \\
\hline Chemical Cost & & & $\$ 0$ \\
\hline Oxidant Chem Cost & & & $\$ 0$ \\
\hline Sludge Removal & & & $\$ 0$ \\
\hline \multicolumn{3}{|l|}{ Other Cost (Annual Cost) } & $\$ 0$ \\
\hline \multicolumn{3}{|l|}{ Land Access (Annual Cost) } & $\$ 0$ \\
\hline \multicolumn{3}{|l|}{ Total Annual Cost: } & $\$ 0$ \\
\hline Other Cost & & & \\
\hline
\end{tabular}

AMD TREAT AMD TREAT MAIN COST FORM

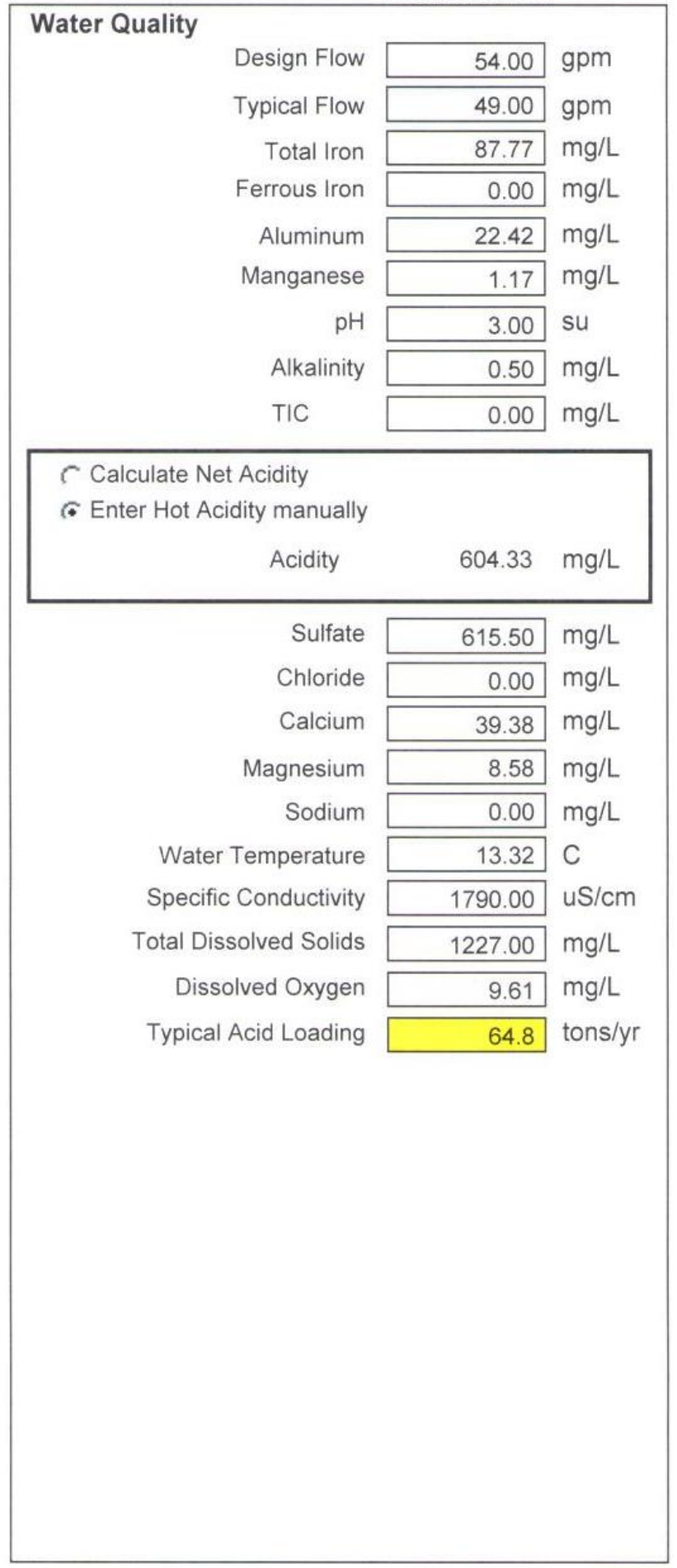

Total Annual Cost: per

$1000 \mathrm{Gal}$ of $\mathrm{H} 2 \mathrm{O}$ Treated $\$ 0.000$

Figure 52: AMD Treat report for the Howesville Greaser system. 
Project Lick Run WV329

Site Name Lick Run \#4

Costs

\begin{tabular}{|c|c|c|c|}
\hline Passive Treatment & $\underline{\mathbf{A}}$ & $\underline{\mathbf{S}}$ & \\
\hline Vertical Flow Pond & & & $\$ 0$ \\
\hline Anoxic Limestone Drain & & & $\$ 0$ \\
\hline Anaerobic Wetlands & & & $\$ 0$ \\
\hline Aerobic Wetlands & 1 & 0 & $\$ 653,716$ \\
\hline Manganese Removal Bed & & & $\$ 0$ \\
\hline Oxic Limestone Channel & 2 & 0 & $\$ 4,392$ \\
\hline Limestone Bed & 1 & 0 & $\$ 159,926$ \\
\hline BIO Reactor & & & $\$ 0$ \\
\hline \multicolumn{3}{|l|}{ Passive Subtotal: } & $\$ 818,034$ \\
\hline \multicolumn{4}{|l|}{ Active Treatment } \\
\hline Caustic Soda & & & $\$ 0$ \\
\hline Hydrated Lime & & & $\$ 0$ \\
\hline Pebble Quick Lime & & & $\$ 0$ \\
\hline Ammonia & & & $\$ 0$ \\
\hline Oxidants & & & $\$ 0$ \\
\hline Soda Ash & & & $\$ 0$ \\
\hline \multicolumn{3}{|l|}{ Active Subtotal: } & $\$ 0$ \\
\hline \multicolumn{4}{|l|}{ Ancillary Cost } \\
\hline Ponds & 1 & 0 & $\$ 572,739$ \\
\hline Roads & & & $\$ 0$ \\
\hline Land Access & & & $\$ 0$ \\
\hline Ditching & & & $\$ 0$ \\
\hline Engineering Cost & 1 & 0 & $\$ 139,077$ \\
\hline \multicolumn{3}{|l|}{ Ancillary Subtotal: } & $\$ 711,816$ \\
\hline \multicolumn{3}{|l|}{ Other Cost (Capital Cost) } & $\$ 0$ \\
\hline \multicolumn{3}{|l|}{ Total Capital Cost: } & $\$ 1,529,850$ \\
\hline \multicolumn{4}{|l|}{ Annual Costs } \\
\hline Sampling & & & $\$ 0$ \\
\hline Labor & & & $\$ 0$ \\
\hline Maintenance & & & $\$ 0$ \\
\hline Pumping & & & $\$ 0$ \\
\hline Chemical Cost & & & $\$ 0$ \\
\hline Oxidant Chem Cost & & & $\$ 0$ \\
\hline Sludge Removal & & & $\$ 0$ \\
\hline \multicolumn{3}{|l|}{ Other Cost (Annual Cost) } & $\$ 0$ \\
\hline \multicolumn{3}{|l|}{ Land Access (Annual Cost) } & $\$ 0$ \\
\hline \multicolumn{3}{|l|}{ Total Annual Cost: } & $\$ 0$ \\
\hline Other Cost & & & \\
\hline
\end{tabular}

AMD TREAT AMD TREAT MAIN COST FORM

\section{Water Quality}

Design Flow

Typical Flow

Total Iron

Ferrous Iron

Aluminum

Manganese

$\mathrm{pH}$

Alkalinity

TIC

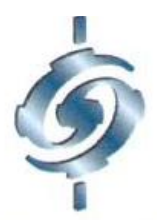

FMDTRERT

$3700.00 \mathrm{gpm}$

$3361.00 \mathrm{gpm}$

$43.19 \mathrm{mg} / \mathrm{L}$

$0.00 \mathrm{mg} / \mathrm{L}$

$23.15 \mathrm{mg} / \mathrm{L}$

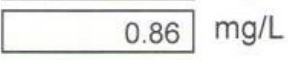

\begin{aligned} \hline 3.39 \\ su \end{aligned}

$0.00 \mathrm{mg} / \mathrm{L}$

$0.00 \mathrm{mg} / \mathrm{L}$

\section{Calculate Net Acidity}

c. Enter Hot Acidity manually

Acidity

$441.74 \mathrm{mg} / \mathrm{L}$

Sulfate

Chloride

Calcium

Magnesium

Sodium

Water Temperature

Specific Conductivity

Total Dissolved Solids

Dissolved Oxygen

Typical Acid Loading

\begin{tabular}{|c|c|}
\hline 598.03 & $\mathrm{mg} / \mathrm{L}$ \\
\hline 0.00 & $\mathrm{mg} / \mathrm{L}$ \\
\hline 40.95 & $\mathrm{mg} / \mathrm{L}$ \\
\hline 14.87 & $\mathrm{mg} / \mathrm{L}$ \\
\hline 0.00 & $\mathrm{mg} / \mathrm{L}$ \\
\hline 12.78 & C \\
\hline 1233.40 & uS/cm \\
\hline 888.25 & $\mathrm{mg} / \mathrm{L}$ \\
\hline 9.75 & $\mathrm{mg} / \mathrm{L}$ \\
\hline $3,252.9$ & tons/yr \\
\hline
\end{tabular}

Total Annual Cost: per

$1000 \mathrm{Gal}$ of $\mathrm{H} 2 \mathrm{O}$ Treated $\$ 0.000$

Figure 53: AMD Treat report for the Lick Run \#4 system. 
Project Lick Run WV329

Site Name Middle Start

\begin{tabular}{|c|c|c|c|}
\hline Passive Treatment & $\underline{A}$ & $\underline{\mathrm{S}}$ & \\
\hline Vertical Flow Pond & & & $\$ 0$ \\
\hline Anoxic Limestone Drain & & & $\$ 0$ \\
\hline Anaerobic Wetlands & & & $\$ 0$ \\
\hline Aerobic Wetlands & 1 & 0 & $\$ 100,436$ \\
\hline Manganese Removal Bed & & & $\$ 0$ \\
\hline Oxic Limestone Channel & 2 & 0 & $\$ 4,392$ \\
\hline Limestone Bed & 1 & 0 & $\$ 18,625$ \\
\hline BIO Reactor & & & $\$ 0$ \\
\hline \multicolumn{3}{|l|}{ Passive Subtotal: } & $\$ 123,453$ \\
\hline \multicolumn{4}{|l|}{ Active Treatment } \\
\hline Caustic Soda & & & $\$ 0$ \\
\hline Hydrated Lime & & & $\$ 0$ \\
\hline Pebble Quick Lime & & & $\$ 0$ \\
\hline Ammonia & & & $\$ 0$ \\
\hline Oxidants & & & $\$ 0$ \\
\hline Soda Ash & & & $\$ 0$ \\
\hline \multicolumn{3}{|l|}{ Active Subtotal: } & $\$ 0$ \\
\hline \multicolumn{4}{|l|}{ Ancillary Cost } \\
\hline Ponds & 1 & 0 & $\$ 28,203$ \\
\hline Roads & & & $\$ 0$ \\
\hline Land Access & & & $\$ 0$ \\
\hline Ditching & & & $\$ 0$ \\
\hline Engineering Cost & 1 & 0 & $\$ 15,166$ \\
\hline \multicolumn{3}{|l|}{ Ancillary Subtotal: } & $\$ 43,369$ \\
\hline \multicolumn{3}{|l|}{ Other Cost (Capital Cost) } & $\$ 0$ \\
\hline \multicolumn{3}{|l|}{ Total Capital Cost: } & $\$ 166,822$ \\
\hline \multicolumn{4}{|l|}{ Annual Costs } \\
\hline Sampling & & & $\$ 0$ \\
\hline Labor & & & $\$ 0$ \\
\hline Maintenance & & & $\$ 0$ \\
\hline Pumping & & & $\$ 0$ \\
\hline Chemical Cost & & & $\$ 0$ \\
\hline Oxidant Chem Cost & & & $\$ 0$ \\
\hline Sludge Removal & & & $\$ 0$ \\
\hline \multicolumn{3}{|l|}{ Other Cost (Annual Cost) } & $\$ 0$ \\
\hline \multicolumn{3}{|l|}{ Land Access (Annual Cost) } & $\$ 0$ \\
\hline \multicolumn{3}{|l|}{ Total Annual Cost: } & $\$ 0$ \\
\hline Other Cost & & & \\
\hline
\end{tabular}

AMD TREAT AMD TREAT MAIN COST FORM $\checkmark$ Calculate Net Acidity

- Enter Hot Acidity manually

Acidity $\quad 263.49 \mathrm{mg} / \mathrm{L}$

Sulfate

Chloride

Calcium

Magnesium

Sodium

Water Temperature

Specific Conductivity

Total Dissolved Solids

Dissolved Oxygen

Typical Acid Loading

\begin{tabular}{|c|c|}
\hline 346.30 & $\mathrm{mg} / \mathrm{L}$ \\
\hline 0.00 & $\mathrm{mg} / \mathrm{L}$ \\
\hline 35.37 & $\mathrm{mg} / \mathrm{L}$ \\
\hline 9.03 & $\mathrm{mg} / \mathrm{L}$ \\
\hline 0.00 & $\mathrm{mg} / \mathrm{L}$ \\
\hline 11.89 & C \\
\hline 998.00 & $\mathrm{uS} / \mathrm{cm}$ \\
\hline 627.00 & $\mathrm{mg} / \mathrm{L}$ \\
\hline 11.22 & $\mathrm{~g} / \mathrm{L}$ \\
\hline 169.7 & tons/yr \\
\hline
\end{tabular}

Total Annual Cost: per $1000 \mathrm{Gal}$ of $\mathrm{H} 2 \mathrm{O}$ Treated $\$ 0.000$

Figure 54: AMD Treat report for the Middle Start system. 
Project Lick Run WV329

Site Name Trib 1 DS

Costs

\begin{tabular}{|c|c|c|c|}
\hline Passive Treatment & $\underline{A}$ & $\underline{\mathrm{S}}$ & \\
\hline Vertical Flow Pond & & & $\$ 0$ \\
\hline Anoxic Limestone Drain & & & $\$ 0$ \\
\hline Anaerobic Wetlands & & & $\$ 0$ \\
\hline Aerobic Wetlands & 1 & 0 & $\$ 111,092$ \\
\hline Manganese Removal Bed & & & $\$ 0$ \\
\hline Oxic Limestone Channel & 2 & 0 & $\$ 4,392$ \\
\hline Limestone Bed & 1 & 0 & $\$ 71,411$ \\
\hline BIO Reactor & & & $\$ 0$ \\
\hline \multicolumn{3}{|l|}{ Passive Subtotal: } & $\$ 186,895$ \\
\hline \multicolumn{4}{|l|}{ Active Treatment } \\
\hline Caustic Soda & & & $\$ 0$ \\
\hline Hydrated Lime & & & $\$ 0$ \\
\hline Pebble Quick Lime & & & $\$ 0$ \\
\hline Ammonia & & & $\$ 0$ \\
\hline Oxidants & & & $\$ 0$ \\
\hline Soda Ash & & & $\$ 0$ \\
\hline \multicolumn{3}{|l|}{ Active Subtotal: } & $\$ 0$ \\
\hline \multicolumn{4}{|l|}{ Ancillary Cost } \\
\hline Ponds & 1 & 0 & $\$ 94,892$ \\
\hline Roads & & & $\$ 0$ \\
\hline Land Access & & & $\$ 0$ \\
\hline Ditching & & & $\$ 0$ \\
\hline Engineering Cost & 1 & 0 & $\$ 28,179$ \\
\hline \multicolumn{3}{|l|}{ Ancillary Subtotal: } & $\$ 123,071$ \\
\hline \multicolumn{3}{|l|}{ Other Cost (Capital Cost) } & $\$ 0$ \\
\hline \multicolumn{3}{|l|}{ Total Capital Cost: } & $\$ 309,966$ \\
\hline \multicolumn{4}{|l|}{ Annual Costs } \\
\hline Sampling & & & $\$ 0$ \\
\hline Labor & & & $\$ 0$ \\
\hline Maintenance & & & $\$ 0$ \\
\hline Pumping & & & $\$ 0$ \\
\hline Chemical Cost & & & $\$ 0$ \\
\hline Oxidant Chem Cost & & & $\$ 0$ \\
\hline Sludge Removal & & & $\$ 0$ \\
\hline \multicolumn{3}{|l|}{ Other Cost (Annual Cost) } & $\$ 0$ \\
\hline \multicolumn{3}{|l|}{ Land Access (Annual Cost) } & $\$ 0$ \\
\hline \multicolumn{3}{|l|}{ Total Annual Cost: } & $\$ 0$ \\
\hline Other Cost & & & \\
\hline
\end{tabular}

AMD TREAT AMD TREAT MAIN COST FORM

\section{Water Quality}

Design Flow

Typical Flow

Total Iron

Ferrous Iron

Aluminum

Manganese

$\mathrm{pH}$

Alkalinity

TIC

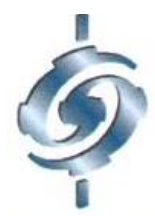

PMDTRERT

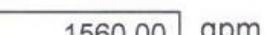

$1560.00 \mathrm{gpm}$

$1417.50 \mathrm{gpm}$

$7.41 \mathrm{mg} / \mathrm{L}$

$0.00 \mathrm{mg} / \mathrm{L}$

$6.54 \mathrm{mg} / \mathrm{L}$

$0.64 \mathrm{mg} / \mathrm{L}$

\begin{tabular}{|r|}
\hline $3.65 \mathrm{su}$ \\
\hline
\end{tabular}

0.00

$0.00 \mathrm{mg} / \mathrm{L}$

$\checkmark$ Calculate Net Acidity

c. Enter Hot Acidity manually

Acidity

$108.77 \mathrm{mg} / \mathrm{L}$

Sulfate $149.00 \mathrm{mg} / \mathrm{L}$

Chloride $0.00 \mathrm{mg} / \mathrm{L}$

Calcium $20.47 \mathrm{mg} / \mathrm{L}$

Magnesium $\quad 5.52 \mathrm{mg} / \mathrm{L}$

Sodium $0.00 \mathrm{mg} / \mathrm{L}$

Water Temperature 14.54 C

Specific Conductivity

Total Dissolved Solids

Dissolved Oxygen

507.00 uS $/ \mathrm{cm}$

ypical Acid Loading

$411.00 \mathrm{mg} / \mathrm{L}$

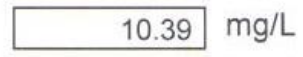
337.8 tons/yr

Figure 55: AMD Treat report for the Trib 1 DS system. 